\title{
MODERN PHILOLOGY: PROMISING AND PRIORITY AREAS FOR SCIENTIFIC RESEARCHES
}

Collective monograph

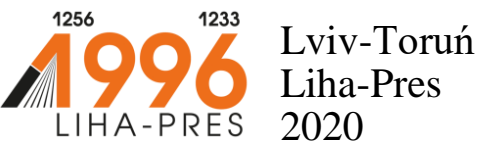




\section{Reviewers:}

Dr. Adam Wróbel, School of Polish Language and Culture of Cuiavian University in Wloclawek (Republic of Poland);

Mgr. Joanna Skiba, Director of the Center for Foreign Languages, Cuiavian University in Wtoctawek (Republic of Poland).

Modern philology: promising and priority areas for scientific researches : collective monograph / L. Didukh, D. Drozdovskyi, T. Konovalenko, V. Koroliova, etc. - Lviv-Toruń : Liha-Pres, 2020. - 216 p. ISBN 978-966-397-194-0

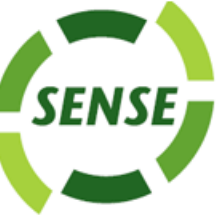

Liha-Pres is an international publishing house which belongs to the category "C" according to the classification of Research School for Socio-Economic and Natural Sciences of the Environment (SENSE) [isn: 3943, 1705, 1704, 1703, 1702, 1701; prefixMetCode: 978966397]. Official website www.sense.nl. 


\section{CONTENTS}

STYLISTIC BASIS OF STEPHEN KING'S

HORROR NOVELS

Liubov Didukh 1

TRANSCULTURATION, CONNECTEDNESS

AND "ALIEN" HOME AS AN ARCHETYPAL CONCEPT

IN POST-POSTMODERN FICTION

Dmytro Drozdovskyi .23

THE HUMAN REALM PERCEPTION IN SALMAN

RUSHDIE'S NOVEL “TWO YEARS, EIGHT MONTHS

AND TWENTY-EIGHT NIGHTS"

Tetiana Konovalenko .41

ADDRESSING POLYPHONICITY

OF DRAMATIC DISCOURSE

Valeriia Koroliova

FEMININE WORLD OF ANN OAKLEY'S NOVELS

Alla Marchyshyna .80

THE METHODOLOGY OF THE MODELLING

OF THE FRACTAL POETICAL MODEL

OF THE WORLD (BASED ON THE BRITISH POETRY

OF THE XIX ${ }^{\mathrm{TH}}$ CENTURY)

Oksana Moskvichova .99

PSEUDOMORPHIC CHARACTERS

OF THE NOVEL "THE PHARMACIST"

BY YURIY VYNNYCHUK IN THE CONTEXT

OF CULTURAL TRADITION (CULTUROLOGICAL

FACETS OF ANALYSIS)

Oleksandra Nikolova, Kateryna Vasylyna 132 
SUPERSTRUCTURE AND HEGEMONY

IN MILAN KUNDERA'S “THE JOKE”

AND POST-POSTMODERN CULTURAL TEXTS

Oksana Prihodko

CARNIVAL FIGURE OF A FOOL-WISECRACKER

IN THE MODERN LINGUISTIC CULTURE

OF THE UNITED STATES AND GREAT BRITAIN

Svitlana Tarasova

THE METHODS OF WORKING WITH THEMATIC

TEXTS IN ESP CLASSES

Svitlana Chernyshova 196 
DOI https://doi.org/10.36059/978-966-397-194-0/1-22

\section{STYLISTIC BASIS OF STEPHEN KING'S HORROR NOVELS}

\section{Liubov Didukh}

\section{INTRODUCTION}

Stephen King is a popular modern writer of horror. Some critics do not approve his writing style, and this is what differentiates him from other popular horror writers. S. King's writing style is very specific and distinctive. The author uses many figures or measures that are not common to most modern writers and this is what makes him and his works so special. This article is focused on stylistic peculiarities of S. King's writing style. As Teodoro Gómez wrote in his book about S. King, 'King was manifoldly christened an American Dickens because of his style, plain and simple in receival ${ }^{, 1}$ [translation mine]. This cannot be argued - his writing style goes down well with most of his readers, although some of the more demanding intellectuals disdain it. Obviously, in the literary community there is controversy on this topic. Some people notice that 'it is very easy to be upset with horror writer Stephen King, for not only has he turned out his annual, successful terrifier, he has also produced a remarkable nonfiction work in which he discusses the meaning and the appeal of the horror story,2. This is not a popular technique among writers - to give away their secrets about how to write to achieve success. Nonetheless, this is just what S. King does. This is a reason of adoration from one side, but also a reason of animosity from the other. Of course, other popular readers do not want everyone to know how to be a good writer - this would cause a huge increase in literary competitors. Thanks to S. King's explanations it is easier for the readers to understand the roots of their fears. It is understandable then, that $\mathrm{S}$. King is more often adored by readers than other writers, although many writers really respect his achievements and talent. Being a best-selling author of horror stories in the world is undisputable. 'But the respect of the literary establishment has always eluded King. For years, the question

${ }^{1}$ Gómez, T., 2008. Człowiek i twórca: Stephen King, trans. M. Mróz. Warsaw, MUZA SA). P. 9.

2 Greeley, A. M., 1986. Stephen King's Horror Has a Healing Power [in:] Miller C. \& Underwood T. (ed.), Kingdom of Fear: The World of Stephen King (P. 19). Falmouth, Hodder \& Stoughton. 
of whether he was a serious writer was answered by a quick tabulation of book sales, film deals, income and sheer volume of output, which added up to a resounding "no". Commercial triumph did not equal literary value. Being a best seller was anathema"3. This fragment of the BBC article shows that S. King's popularity and the perception of his figure as a serious writer are not equal. Various people have been asked a question about whether S. King is a serious writer or not. Some of the answers are quoted in the analysed article. For example, Harold Bloom, the legendary critic said: 'I've described King in the past as a writer of penny dreadfuls, but perhaps even that is too kind. He shares nothing with Edgar Allan Poe. What he is is an immensely inadequate writer on a sentence-by-sentence, paragraph-by-paragraph, book-by-book basis . . . Stephen King is beneath the notice of any serious reader who has experienced Proust, Joyce, Henry James, Faulkner and all the other masters of the novel ${ }^{4}$. If compared to such great artists as Proust or Poe, S. King truly is not similar to them. According to some readers, this is his main advantage. According to many critics, his biggest disadvantage. All of this is attributable to his specific writing style.

The material of the research consists of different works written by S. King: The Shining, It, Carrie. And analysing stylistic features of three of the most popular novels written by the master of horror the article presents how distinctive S. King's style is, what impact it has on the reader and why did the writer decide to use such stylistic measures to achieve his goal.

\section{Genre nature of horror fiction on the basis of Stephen King's works}

Style is a writer's identification mark. It makes him special, different, unique. At least this is definitely what can be said about S. King's writing style. Both his fans and his critics would agree that the master of horror has a style that does distinguish itself.

$\mathrm{S}$. King is aware of the fact that many people recognize his style as very simple and casual. 'He writes in what E.B. White once called the "plain style" - what King himself has termed "the literary equivalent of a Big Mac and a large fries from McDonald's." This seemingly offhand,

${ }^{3}$ Ciabattari, J., 2014. Is Stephen King a Great Writer? Retrieved March 13, 2019, from www.bbc.com.

${ }^{4}$ Ciabattari, J., 2014. Is Stephen King a Great Writer? Retrieved March 13, 2019, from www.bbc.com. 
conversational style, when combined with his appealing characters, produces an almost immediate intimacy with the reader, ${ }^{5}$. This dictum shows S. King's approach to his 'plain style'. He understands that readers like simple sentences, just like they love Big Mac and fries although they are very common. Obviously, according to the writer, 'common' does not mean 'bad'.

Most of the great, known writers like Shakespeare tried to use solemn, ornate language. Children at schools now analyse their works and learn about writers' great art. Of course, humanity needs writers like that. Nevertheless, a book has also something more to offer the reader. It is supposed to be a pastime, to make a person relax after a long day with a cup of tea and a really good story written by some talented writer. This is exactly what S. King can do. He has been compared by D.E. Winter to a boatman. His goal is to ferry people from one bank to another, from the beginning of a story to the end of it. He is supposed to do it smoothly and rivetingly. 'In the horror fiction of Stephen King, we can embark upon the night journey, make the descent down the dark hole, cross the narrowing Reach [the name of the river from one of King's stories - M.T.], and return again in safety to the surface - to the near shore of the river of death. For our boatman has a master's hand' ${ }^{6}$. Even though King's style is not very sophisticated, it is good enough to engage the reader in a masterful way. Many readers appreciated this ability and loved his novels truly.

According to S. King, there are two simple statements about writing. The first one is: 'good writing bargains on mastering the basis (vocabulary, grammar, elements of style), [translation mine]. The second rule says: 'although you cannot make a bad writer become a professional writer, and although it is impossible to create a genius out of a good writer, you can, if you put enough effort, hard work and commitment in it, lift a professional to the level of the good author ${ }^{8}$ [translation mine]. This quotation shows us King's approach to the activity which is writing. The

${ }^{5}$ Winter, D. E., 1989. The Art. Of Darkness: The Life and Fiction of the Master of the Macabre: Stephen King. London, Hodder \& Stoughton. p. 34.

${ }^{6}$ Winter, D. E., 1989. The Art. Of Darkness: The Life and Fiction of the Master of the Macabre: Stephen King. London, Hodder \& Stoughton, p. 162. S-ka. p. 112.

${ }^{7}$ King, S., 2001. Jak pisać: Pamiętnik rzemieślnika. Warsaw, Prószyński i S-ka p. 112.

${ }^{8}$ King, S., 2001. Jak pisać: Pamiętnik rzemieślnika. Warsaw, Prószyński i 
author understands that a bad writer will never become a genius, but the point is to work on his writing. Even such a popular writer as S. King can always improve his style, find a new way of expressing his thoughts and ideas. The only thing he needs to do is try and not give up.

Discussing the stylistic features of S. King's works, many factors should be taken into consideration. One of them is writing rhythm. This is how the author talks about it: 'I'm not very concerned with style, but I am concerned with the balance. Language should have a balance the reader can feel and get into - rhythm to the language as it moves along. Because if the reader is seduced in the story, then it carries him away'. Most people connect rhythm with music, but it turns out that books also can, and should, have a rhythm. The basis of this field is narration. When the narration is good, readers cannot simply postpone reading the next chapter. They want to know what happens next, they are so much into the plot that they do not even realise how much the story implicated them. Another writer, Michael McDowell, admitted that he is jealous about how King can create such an effective narration. 'It has become increasingly apparent to me that books rise or fall by the rhythm of the narrative. A story can carry you along - despite lapses in grammar, probability, or tone - if the rhythm is right ${ }^{10}$ - he wrote.

This rhythm can be easily noticed in King's works. The descriptions are never too long - just enough to give all the important information. 'And the climaxes are exactly right. The dynamite is laid, stick by stick, and every one of them goes off, in a precise, rhythmic pattern ${ }^{, 11}$. Every S. King's novel is perfectly rhythmic - not too long (even though It can be even 1300 pages long) and not too short, because when one reads it, he does not feel like the story is dragging or like there is too few information. The plot is irrepressible and gripping, all of this thanks to King's narration.

${ }^{9}$ McDowell, M., 1986. The Unexpected and the Inevitable [in:] Miller C. \& Underwood T. (ed.), Kingdom of Fear: The World of Stephen King (p. 81). Falmouth, Hodder \& Stoughton.

${ }^{10}$ McDowell, M., 1986. The Unexpected and the Inevitable [in:] Miller C. \& Underwood T. (ed.), Kingdom of Fear: The World of Stephen King (p. 81). Falmouth, Hodder \& Stoughton, p. 84.

${ }^{11}$ McDowell, M., 1986. The Unexpected and the Inevitable [in:] Miller C. \& Underwood T. (ed.), Kingdom of Fear: The World of Stephen King (p. 81). Falmouth, Hodder \& Stoughton. 
Apart from narration, S. King states that stories consist of two more factors. One of them are descriptions, the second one - dialogues ${ }^{12}$. Description is very important, because it allows the reader participate in the story. According to the master of horror, making good descriptions is a thing to learn. At first, it should have proper length. 'Too meagre description makes the reader feel bewildered and lost. Too detailed one buries him under a stack of pictures and details. The trick is to find the golden mean ${ }^{, 13}$ [translation mine]. The truth is - it is easy to send the reader to sleep with too long description. It is difficult to make him go for the story again after that. This is also an element of the right rhythm. To keep the right pace, the writer must be aware of what S. King wrote about descriptions. The author suggests to allow the readers to supply the image of his characters with faces, figures and clothes ${ }^{14}$. This would be impossible if he gave an exact description of a protagonist. When the reader's imagination starts working, he becomes the co-author of the story on the level of his mind. When we read that Carrie was a 'toad among the swans' and a 'clumsy, squat girl with pimples all over her neck, back and buttocks ${ }^{15}$ [translation mine], it is easy to imagine the rest - her hair, her face, her clothes and the way she moves. It is not necessary for S. King to enumerate every piece of her wardrobe. The reader gets the point - Carrie looked like a scapegoat.

S. King also argues that descriptions of characters should not include any clues about their personality. He also thinks that describing how intelligent were protagonist's blue eyes and how brashly his chin was upstretched proclaims that the author is lazy and uses poor techniques ${ }^{16}$. 'According to me, a good description usually consists of a few wellmatched details that symbolise anything else. In most cases, those details are the first ones that come to my mind. They will surely make a good beginning ${ }^{, 17}$ [translation mine]. This statement shows that it is difficult to

${ }^{12}$ King, S., 2001. Jak pisać: Pamiętnik rzemieślnika. Warsaw, Prószyński i S-ka. p. 129.

${ }^{13}$ King, S., 2001. Jak pisać: Pamiętnik rzemieślnika. Warsaw, Prószyński i S-ka, p. 138.

${ }^{14}$ King, S., 2001. Jak pisać: Pamiętnik rzemieślnika. Warsaw, Prószyński i S-ka. p. 138.

${ }^{15}$ King, S., 2013. Carrie, trans. D. Górska. Warsaw, Prószyński i S-ka. p. 10.

${ }^{16}$ King, S., 2001. Jak pisać: Pamiętnik rzemieślnika. Warsaw, Prószyński i S-ka. p. 139.

${ }^{17}$ King, S., 2001. Jak pisać: Pamiętnik rzemieślnika. Warsaw, Prószyński i S-ka. 
make a description that would be too meagre, it is much easier to make the one which is too overbearing. Fortunately, S. King's descriptions are always perfectly attuned.

What about his dialogues? S. King wrote that dialogue is the key factor that determines the personality of the character - only people's acts tell about them more than words . . . and one of the basic rules of good prose is never to talk about something you can show ${ }^{, 18}$ [translation mine]. When the dialogue is good, the reader will pick up on whether the character is intelligent or foolish, amusing or uptight. Great examples of S. King's dialogues can be found in It. One of them between Beverly and her dad shows the situation in their house:

" "Where's the bacon?"

"Gone, Daddy. We finished it yesterday."

"Cook me a hamburger."

"There's only a little bit of that left, $t$-"

"The paper rustled, then dropped. His blue stare fell on her like weight."

"What did you say?" he asked softly.

"I said right away, Daddy." "19.

Although in this short piece of text there is no mention of relationship between Bev and her dad, the reader can easily draw a lesson from this conversation. The author does not need to write that Bev was afraid of her father and had to fulfil all of his wishes - it is obvious.

Another extremely important factor of S. King's success as a writer is the way he creates his characters. Anyone who ever read any novel written by him probably remembers the protagonists very well - their way of thinking, their experience and their features. Although, as mentioned above, King allows the reader to imagine the character in his own way, his characters are never dull. They are always vividly presented, all of them have some important history that the reader can find out about while progressing with the plot. 'King's genius as a prose stylist is his portrayal of these characters in strikingly real, human terms. His works repeatedly dramatize the compelling human consequences of the possession of strange talents, by developing a sympathetic reader identification with the protagonist and then producing an intense conflict on both physical and

${ }^{18}$ King, S., 2001. Jak pisać: Pamiętnik rzemieślnika. Warsaw, Prószyński i S-ka, p. 143.

${ }^{19}$ King, S., 2011. It. London, Hodder \& Stoughton. pp. 482-483. 
emotional levels ${ }^{20}$. Starting with Carrie, through Jack Torrance in The Shining to Annie Wilkes in Misery, all of King's characters are remarkable. They leave a permanent trace in the reader's mind. However, the author admits that his characters are not so colourful from the very beginning. In On Writing he wrote that they are flat at the start, have no personal features. 'I never demand my characters doing what I want. Contrarily, I want them to do everything their own way. Sometimes the effect is what I expected, yet sometimes I get something I was completely not prepared for ${ }^{21}$ [translation mine]. S. King is a supporter of allowing the story take its own course in a way that might surprise him and that will surely surprise the reader. The author does not necessarily have to control everything. King wrote that for him what happens to his characters as the story develops depends only on what he is finding out about them, in other words, on how they foster themselves ${ }^{22}$. Although the author does not argue that this is the best way to create protagonists, this is how he works. This is one of King's secrets.

S. King's characters are chillingly real. This is an effect of the way of presenting them to the reader. In On Writing S. King gives an example of Annie Wilkes, the nurse from Misery who imprisoned Paul Sheldon, a famous writer. 'Annie Wilkes . . might seem to us a psychopath, but you need to understand, that in her opinion she is completely normal - in fact, she perceives herself as a heroine... If I manage for a while to show you the world in her eyes - I will make you understand her madness - then maybe I can make her a person you are going to pity or even start to identify with. Result? She will become to you more threatening than ever - because she will be so real ${ }^{, 23}$ [translation mine]. If S. King would tell his readers that Annie was a crusty, mean brimstone with the worst intent, she would make them feel only hate. However, when the reader sees that this is not her fault, that she really does not realize the weight of her actions, he starts to feel sorry for her. Feelings for Paul start to engage with feelings for Annie. The reader is torn inside, but also terrified,

${ }^{20}$ Winter, D. E., 1989. The Art. Of Darkness: The Life and Fiction of the Master of the Macabre: Stephen King. London, Hodder \& Stoughton. p. 93.

${ }^{21}$ King, S., 2001. Jak pisać: Pamiętnik rzemieślnika. Warsaw, Prószyński i S-ka. p. 130.

${ }^{22}$ King, S., 2001. Jak pisać: Pamiętnik rzemieślnika. Warsaw, Prószyński i S-ka, p. 151.

${ }^{23}$ King, S., 2001. Jak pisać: Pamiętnik rzemieślnika. Warsaw, Prószyński i S-ka, p. 152. 
because as he starts to understand the character, he realizes that this could be a real person, even his neighbour. This is why S. King's novels arouse emotions and involve readers in the action.

One more factor that makes S. King's writing style special is the language he is using. This is what most of the critics argue about, that the language used by King is too plain, too common to call him a good writer. Obviously, thousands of readers in the world think otherwise.

In the book entitled The Linguistics of Stephen King there are many types of language means specified. It's obvious, that we use different language when we are at home with family, and different when we are in the office or at work. Those varieties of language are called 'registers' or functional styles. 'Stephen King is a master of mixing in these different types of registers in order to create a . . . "defamiliarizing effect" . . . Hohne observes this effect in Stephen King's work: "a fine example of its [language's] slippery dual nature is Stephen King's writing, where there is a great deal of tension between the heteroglossic orality that is slang speech, which codifies a knowledge rejected by those in power, and monologic orality, which embodies that power". King's texts, then, contain both "official" and "unofficial" language 24 . As the master of horror, S. King can combine different stylistic genre peculiarities in order to achieve his goal. His simple language is used to form a kind of friendship between his readers and characters of his novels. Official language is used in order to introduce some serious scenes, the atmosphere of dignity. Both of these 'registers' create a complete picture of the situation for the recipient and allow him to feel like a part of the story. One more example of S. King's unofficial language can be found in It: 'But could Silver go? Could he? Christ! And it was a damned good thing he could. . . He had raced to beat the devil that day, oh yeah, for sure, don't you just know it ${ }^{25}$. Reading fragments like this one, a reader feels as if the narrator was his best friend and they were talking about something that really happened. Reading becomes a real pleasure, not a torment. The language is easy to understand and it has one more advantage: it speeds up the action.

Genre elements occurring in S. King's works are also an important clue on his specific style. As mentioned above, most of his novels can be certainly identified as horror novels with a strong

${ }^{24}$ Anderson, J.A., 2017. The Linguistics of Stephen King: Layered Language and Meaning in the Fiction. Jefferson, McFarland. pp. 193-194.

${ }^{25}$ King, S., 2011. It. London, Hodder \& Stoughton. pp. 482-483. 
psychological adjunct. Narrative, although having a perfect rhythm, is often enriched with the use of graphic means, such as brackets, italics and other elements used in order to show the deeper level of the plot. Rising action in King's novels usually stalls for most of the plot, so the climax occurs rather by the end of the story, which keeps the reader guessing until the end. The setting is another repeatable element of horror novels written by S. King, for the action usually takes place in a small town in America, usually in Maine. What is more, many of these towns are fictive and mentioned in more than one story. 'In stories like It, he borrows liberally from real places and landmarks, highways and scenery, even real street corners ${ }^{26}$. This type of setting introduces a special atmosphere from the beginning of the book. Repetitive patterns in King's works also consist of characters - usually there are some youngsters, a writer who wants to achieve success, a man with an alcohol problem and a woman who suffers from it.

Last but not least, it is not only important how S. King writes - it also matters what he writes about. For example, children or teenagers are very important in his works. 'His stories are songs of innocence and experience, juxtaposing childhood and adulthood - effectively completing the wheel whose turn began in childhood by reexperiencing those days from a mature perspective. . . This is a powerful motif; it may cause the reader to look to his or her life as well as that of the characters ${ }^{, 27}$. Horror is scary when it involves adults, but it is terrifying when children are involved. The fact that $\mathrm{S}$. King uses children as characters of many of his novels also allows the reader to understand their feelings ant take their point of view - everyone was a child.

However, the author also mentions another important topic. 'King holds that the most essential element of an effective horror story is love of characters: "You have got to love the people. That's the real paradox. There has to be love involved, because the more you love . . then that allows the horror to be possible. There is no horror without love and feeling . . ., because horror is the contrasting emotion to our understanding of all the things that are good and normal. Without a

${ }^{26}$ Romano, A., 2018. Stephen King Has Spent Half a Century Scaring Us, But His Legacy Is So Much More Than Horror. Retrieved April 4, 2019, from www.vox.com.

${ }^{27}$ Winter, D. E., 1989. The Art. Of Darkness: The Life and Fiction of the Master of the Macabre: Stephen King. London, Hodder \& Stoughton. P. 11. 
concept of normality, there is no horror ${ }^{28}$. Even though this is connected with the plot, not directly with the writing style, it has a huge impact on the credibility of the story. If the readers do not get involved in characters' feeling, then their life or death does not mean so much to them. Where there is love, emotions are highlighted, and they play a major role in every horror. Among others, this important motif was shown in The Shining. Although Jack Torrance has problems with alcohol and child abuse, in fact he can be a loving husband and father. A few fragments in the novel show strong feelings between Jack and his wife, Wendy. He has many flaws and did many bad things in his life, but 'despite his shortcomings indeed, in part because of them - Jack is intensely human, sympathetic, and forgivable 29 . While the novel shows this effective love of characters and this is its great asset, the movie based on it failed to show these emotions. If Jack Torrance is not introduced as a person who can forgive and understand, his character loses vividness and the story is not frightening enough.

Except love, there is one more emotion used in many S. King's novels, also in The Shining - aggression. In his interview with D.E. Winter King admitted: 'I have always had tremendous feelings of aggression that it seemed necessary to cover up, to hide. And my writing has a clear channel for that - I think that this is why there is so much destruction in my early books, because it was a way of ridding myself of a lot of that energy that couldn't be drained in day-to-day life 30 . This is easy to notice - most of King's early novels have many scenes of destruction. His first published story, Carrie, ends with lots of blood, fire and death. Of course, horror is often associated with destruction, but it usually comes from supernatural creatures. S. King calls it down with people. His characters can be very aggressive and this is the most terrifying part for many readers, because it is incredibly realistic. We can hear every day how cruel people can be for another people, so S. King's characters are for us completely real.

${ }^{28}$ Winter, D. E., 1989. The Art. Of Darkness: The Life and Fiction of the Master of the Macabre: Stephen King. London, Hodder \& Stoughton, pp. 55-56.

${ }^{29}$ Winter, D. E., 1989. The Art. Of Darkness: The Life and Fiction of the Master of the Macabre: Stephen King. London, Hodder \& Stoughton. P. 56.

${ }^{30}$ Winter, D. E., 1989. The Art. Of Darkness: The Life and Fiction of the Master of the Macabre: Stephen King. London, Hodder \& Stoughton., p. 100. 
It was already mentioned that S. King's style is very distinctive. However, the author often admits that different horror writers were an inspiration for him.

In Danse Macabre S. King describes the day that probably was extremely important for his future career. He was 12 or 13 years old when he discovered an old box with his father's books. The author admits that the box was a real treasury of Avon paperbacks. Avon was then a publishing company which specialised in fantasy and horror literature. This discovery must have been really important to S. King, as he describes it with true affection. King continues: 'The pearl of the collection was H.P. Lovecraft's collection of short stories from year 1947 entitled The Lurking Fear' ${ }^{31}$ [translation mine]. He even remembers exactly the cover which is to him the best summary of Lovecraft's work. Although King admits that it was not his first meeting with horror, this collection was his first encounter with the genre's serious literature. 'This book, a gift from the father who left, allowed me for the first time to taste the reality beyond the minor movies displayed on Saturday afternoons 32 [translation mine]. These statements show how important role H.P. Lovecraft played in S. King's life. Further in Danse Macabre S. King admitted that Lovecraft opened a way for him, similarly as for Robert Bloch, Clark Ashton Smith, Ray Bradbury and others ${ }^{33}$. Although King's mother and aunt were opposed to this, his young brain was absorbing horror stories like a sponge. He started creating his own works very soon.

S. King admitted that it is normal to capture the writing style of the author that you read a lot. 'There is nothing bad about it. When, as a kid, I was reading Ray Bradbury, I was writing like Ray Bradbury everything was green, wonderful . . When I was reading James M. Cain, everything I wrote was brief, curt and tough as steel. When I was reading Lovecraft, my prose became decorative and baroque ${ }^{34}$ [translation mine]. This is normal when an author is fascinated with another artist's style. The difficulty lies in moulding an own characteristic way of writing. Further in the book King wrote: 'Stylistic repetition is a minor problem it is an entirely acceptable method of starting a writing career (and,

\footnotetext{
${ }^{31}$ King, S., 1995. Danse Macabre. Warsaw, Prószyński i S-ka. P. 145.

${ }^{32}$ King, S., 1995. Danse Macabre. Warsaw, Prószyński i S-ka.

${ }^{33}$ King, S., 1995. Danse Macabre. Warsaw, Prószyński i S-ka, p. 146.

${ }^{34}$ King, S., 2001. Jak pisać: Pamiętnik rzemieślnika. Warsaw, Prószyński i S-ka. p. 116.
} 
indeed, it cannot be dodged: every consecutive stage of a writer's work starts with some repetition), however, it is not possible to imitate another author's approach to the given genre ${ }^{35}$ [translation mine]. This approach is probably one of the most important elements in developing own writing style - every writer needs to feel his genre instead of trying to imitate what somebody else feels. This is why S. King gives an advice to those, who want to become good writers: 'Throw away Poe and Lovecraft before you start . . Both of these fine writers were rococo stylists, weaving words into almost Byzantine patterns . . . In spite of the antique charm both hold for modern readers, most editors regard the style as outdated and bankrupt ${ }^{36}$. Poe, Lovecraft and other horror writers can be a great inspiration, but their works should not become a form of a formula that can only be changed for some special purpose.

According to $\mathrm{T}$. Gómez, an author of a book that analyses S. King's works, in King's novels an influence of Poe, Lovecraft or Tolkien can be seen. However, while these other authors describe terrifying things with the words that hold the rank of art, S. King comes across as a normal guy, who tells an extraordinary story to his friend and engrosses him $^{37}$. This is probably the main feature that makes King's works different in the genre. This author is not trying to scale the heights of his artistic possibilities and give his horror stories a beautiful rim.

To compare S. King and H. P. Lovecraft, it is good to analyse the way both of these authors introduce blood into their stories. One of Lovecraft's short stories entitled The Picture in the House is only about 6 pages long, but conducting blood takes nearly one paragraph: 'The open book lay flat between us, with the picture staring repulsively upward. As the old man whispered the words "more the same" a tiny spattering impact was heard, and something shewed on the yellowed paper of the upturned volume. I thought of the rain and of a leaky roof, but rain is not red. On the butcher's shop of the Anzique cannibals a small red spattering glistened picturesquely, lending vividness to the horror of the engraving. The old man saw it, and stopped whispering even before my

${ }^{35}$ King, S., 2001. Jak pisać: Pamiętnik rzemieślnika. Warsaw, Prószyński i S-ka, p. 127.

${ }^{36}$ King, S., 1986. The Horror Writer and The Ten Bears. [in:] Miller C. \& Underwood T. (ed.), Kingdom of Fear: The World of Stephen King (p. 14). Falmouth, Hodder \& Stoughton.

37 Gómez, T., 2008. Człowiek i twórca: Stephen King, trans. M. Mróz. Warsaw, MUZA SA). p.p. 9-10. 
expression of horror made it necessary; saw it and glanced quickly toward the floor of the room he had left an hour before. I followed his glance, and beheld just above us on the loose plaster of the ancient ceiling a large irregular spot of wet crimson which seemed to spread even as I viewed $i t^{38}$. The fragment is very artistic indeed. While reading it, the reader can imagine the atmosphere in the room, can almost hear the first drop of blood falling on the paper and see how red it is. In comparison, S. King conducts blood in his stories very quickly. He did that already in his first published novel, Carrie: 'Suddenly, a fountain of red spouted from above. It spattered over the painting, there were streams of red on it. I knew immediately, even before it reached them, that it was blood ${ }^{39}$ [translation mine]. In this case, characters do not wonder whether it is blood, or maybe rain or paint. It does not start with a single drop. S. King hits his readers with action, with an unexpected and sudden event. The recipient does not even have time to predict what might happen. Once again, language is the greatest tool used by S. King to surprise his readers and to differentiate from other horror writers.

One more difference between King and his predecessors was given by Robert Bloch, another famous horror writer. He wrote: 'While . . Poe and Lovecraft came into full command of their fantasies they appeared to have an uncertain grasp upon realities; they had difficulty in dealing with everyday characters and situations. King, however wild his fancies, roots his work in the real world of today. His "normal" characters speak and think in the gritty language and slang idioms of the present generation ${ }^{, 40}$. This is another specific feature of S. King - his characters seem so normal that they could be our neighbours or even friends. The way they speak, how they behave is well known to readers. That ability to create such familiar characters probably emanates from being a good observer of the world that surrounds the author. Authors such as Poe or Lovecraft could not do this as well as S. King, and R. Bloch knew about it because he used to correspond with H.P. Lovecraft. 'All of the accounts say that Lovecraft was a terrible snob and, simultaneously, a very shy person (in addition, he was a $100 \%$ racist ...), a writer who corresponded a lot, but could not

${ }^{38}$ Lovecraft, H.P. The Picture in the House. Retrieved March 27, 2019, from http://www.hplovecraft.com/writings/texts/fiction/ph.aspx

${ }^{39}$ King, S., 2013. Carrie, trans. D. Górska. Warsaw, Prószyński i S-ka. p. 143.

${ }^{40}$ Bloch, R., 1986. Monsters in Our Midst [in:] Miller C. \& Underwood T. (ed.), Kingdom of Fear: The World of Stephen King (p. 25). Falmouth, Hodder \& Stoughton. 
deal with interpersonal relations. If he lived today, he would probably be a steady guest of online chats ${ }^{41}$ [translation mine]. This fragment of S. King's books shows that Lovecraft could not create real dialogues and reliable characters if he did not maintain contacts with other people. He lived in his imaginary world full of surrealistic creatures and figures.

A good example of Lovecraft's inability to create good dialogues is a fragment of his story entitled The Colour out of Space: 'Nothin'... nothin'... the colour... it burns... cold an' wet... but it burns... it lived in the well... I seen it... a kind o' smoke... jest like the flowers last spring... the well shone at night... Thad an' Mernie an' Zenas... everything alive... suckin' the life out of everything... in that stone... it must a' come in that stone . . ${ }^{42}$. Although S. King really respects Lovecraft for his work, he admitted that his genius in writing horror stories ended on dialogues. The fragment quoted above is an utterance of a moribund farmer and it drags on for more than 16 lines. People do not talk like this, even on their death bed. The dialogue lacks energy and life, it sounds dry and unnatural ${ }^{43}$. This is definitely a difference between Lovecraft and King. King's dialogues are always concrete and usually short, yet still interesting and giving the reader plenty of information about his characters.

The setting of S. King's stories is different too. Most horrors written by Poe or Lovecraft took place in Europe, in some magnificent buildings from the old times that gave the feeling of going back in time for the reader. King's novels are set in modern America, usually in a small town in Maine. Not all of towns mentioned by King even exist, many are just fiction. However, there is usually a small community in town which is placed far from a big city, so the atmosphere is getting tense very quickly.

What is more, S. King can implement optimism into his stories, even though they are terrifying. While H.P. Lovecraft's stories often embrace 'cosmic pessimism .. ., King's stories typically celebrate the existence of good ${ }^{44}$. In many of his novels a religious motif can be

${ }^{41}$ King, S., 2001. Jak pisać: Pamiętnik rzemieślnika. Warsaw, Prószyński i S-ka. p. 145.

${ }^{42}$ Lovecraft, H.P. The Collour out of Space. Retrieved March 27, 2019, from https://repositorio.ufsc.br

${ }^{43}$ King, S., 2001. Jak pisać: Pamiętnik rzemieślnika. Warsaw, Prószyński i S-ka. pp. 144-145.

${ }^{44}$ Winter, D. E., 1989. The Art. Of Darkness: The Life and Fiction of the Master of the Macabre: Stephen King. London, Hodder \& Stoughton, p. 110. 
noticed, most obviously in Carrie. Those mentions of God have a purpose - in every story it is different, but it is an important part of the plot. A mixture of horror and religion can seem strange, so not many horror writers have used it before. Nowadays, it can be noticed in many horror movies.

All in all, there are many distinctions between works written by S. King and by other horror writers. They are surely a result of the distinctive S. King's style discussed.

\section{Stylistic peculiarities of the horror novels Carrie, The Shining and It by Stephen King}

Genre peculiarities of the three discussed novels (Carrie, The Shining, It) show many similarities between S. King's works. However, each of his novels is different, has a special theme, matching characters and concerns different important motifs. Although S. King's style is easily recognizable for every horror reader, the author's style can also vary depending on the novel.

There are few important elements that make Carrie a piece of art in S. King's collection of horrors. At first, its main character is a young girl - a motif that occurs in many other novels written by the king of modern horror, where children or teenagers are hurt (e. g. Cujo) or are hurting somebody (e.g. Pet Sematary). It seems like nobody understands Carrie and nobody even tries to. However, Carrie turns out to be more than just a 'teenaged ugly duckling ${ }^{, 45}$ and she discovers her superpowers. The way Carrie is described is impressive. Even though, as it was already explained, S. King does not focus too much on giving detailed descriptions of his characters, readers can discover Carrie's appearance and personality while the action develops.

At the beginning of the story, the girl is presented as a klutz, hated by her peers, ignored by the teachers and abused by her mother. However, interludes in the text coming from the local newspapers or chronicles show the reader a different, unknown side of Carrie. For example, a note from an 'Enterprise' weekly said: 'On August 17 in Chamberlain, on Carlin Street, the rain of rocks appeared out of a clear blue sky. The fact was confirmed by many reliable people. The rocks fell mainly on Margaret White's house, seriously damaged the roof and destroyed two

45 Winter, D. E., 1989. The Art. Of Darkness: The Life and Fiction of the Master of the Macabre: Stephen King. London, Hodder \& Stoughton. p. 34. 
gutters and the drain worth about 25,000 dollars. Ms White is a widow and lives with her 3-year-old daughter, Carrietta ${ }^{\text {,4 }}$ [translation mine]. Following extracts confirm readers' suspicions that Carrie was responsible for all of the weird events described. Her character in the reader's imagination starts to gain more respect and slowly turns from a clumsy teenage girl to a powerful young woman.

One element that connects Carrie with The Shining - another King's popular novel - is featuring 'children of extraordinary psychokinetic abilities ${ }^{47}$. However, this time the horror does not come from the child. In The Shining almost all of the terror takes place in characters' imagination and subconsciousness, which is a novelty in the genre. M. Kruszelnicki directs the attention to a short fragment of this novel that tells us a lot about S. King's strategies: 'Blood-chilling gastness took his breath away. Yes. Yes. There was something, something terrifying, that the Overlook [name of the hotel - M.T.] saved for such an occasion. Maybe a huge spider buried under these withered leaves or a rat... or maybe corpse of some child who died here, in this playground. Did someone really die in here? Yes, perhaps. He was thinking about the woman in the bathtub. About the blood and the brain on the wall of the presidential suite. About a small child that fell off the ladder or the swing and with its skull fracted is crawling behind him in the dark, smiling, looking for his last companion in this timeless playground. He will hear it coming in a moment' (translation mine) ${ }^{48}$. In these few sentences the author used many techniques of scaring the reader. Child's imagination, darkness, claustrophobia, fear against spiders, rats and dead people - all of this is happening in just one small mind.

The Shining is also special for some other reasons. Firstly, the novel's main character, Jack Torrance, is a writer - one of S. King's favourite motifs. When the author describes Jack's efforts to write something successful it reminds the reader of King's writing cradle. The technique of describing characters is masterful also this time. Jack Torrance is presented in various ways depending on the person related to him. In the eyes of his son, Danny, Jack was a good father, sometimes getting angry without a serious reason, but he tried to fight his

${ }^{46}$ King, S., 2013. Carrie, trans. D. Górska. Warsaw, Prószyński i S-ka. P. 9.

47 Indick, B.P., 1986. King as a Writer for Children . [in:] Miller C. \& Underwood T. (ed.), Kingdom of Fear: The World of Stephen King (p. 201). Falmouth, Hodder \& Stoughton.

${ }^{48}$ King, S., 1998. The Shining. Warsaw, Prószyński i S-ka. Pp. 330-331. 
weaknesses. Danny did not want his mom to worry about dad. He could also read their thoughts. 'Daddy probably thought that they would have a better life if he had left. That the pain would stop. Daddy nearly always felt pain, mainly because of the Bad Thing. Danny could usually capture it: dad's permanent desire to hole up in a dark corner, look at the colour $T V$, eat peanuts and do the Bad Thing, until his thoughts calm down and stop torturing him' ${ }^{49}$ [translation mine]. Although Danny did not understand that 'the Bad Thing' was drinking, he knew that mom hated when dad was doing it. Wendy's point of view, however, was often changing. In the second chapter, she is so sad that she nearly cries: 'Jack and his pride! ${ }^{50}$ [translation mine]. Later, from Danny's thoughts it is obvious, that Wendy was thinking about the divorce. She truly hated Jack when he broke their son's arm. But in the sixth chapter we can read: 'Her man. She smiled dimly in the dark. . . The smile expressed both sadness and pleasure, for an expression "her man" evoked one hundred different feelings ${ }^{\text {,51 }}$ [translation mine]. This is the best example of Jack's ambiguity. His family loved him, feared him and hated him by turns. In Jack's own eyes, however, 'he always thought Jack Torrance is a really nice guy, who will have to learn how to moderate his anger one day ${ }^{, 52}$ [translation mine]. The reader's point of view on this particular character changes from chapter to chapter. Creating characters like this one is an interesting novelty in the field of horror stories and it is one of identification marks of S. King's writing style.

Another element that makes The Shining even more terrifying is the fact that evil can be inside of each of us. As S. King himself wrote in his book Danse Macabre, the main difference between the old and the new horror literature is connected with the characters' narcissistic personality; that monsters can not only appear on Maple Street, but they can also look out of our mirror at any moment ${ }^{53}$. This is exactly what is happening to Jack Torrance. The quintessence of the horror is the fact, that the hotel in which Jack and his family are staying is trying to change them, to turn them into different people. In the case of Jack, the head of the family, a husband and a father, it turns out to be a terrific change - to

${ }^{49}$ King, S., 1998. The Shining. Warsaw, Prószyński i S-ka. p. 37.

${ }^{50}$ King, S., 1998. The Shining. Warsaw, Prószyński i S-ka, p. 18.

${ }^{51}$ King, S., 1998. The Shining. Warsaw, Prószyński i S-ka, p. 56.

${ }^{52}$ King, S., 1998. The Shining. Warsaw, Prószyński i S-ka, p. 128.

${ }^{53}$ King, S., 2005. Danse Macabre, trans. P. Braiter, P. Ziemkiewicz. Warsaw, Prószyński i S-ka. p. 352. 
the extent of attempting to kill his family. This is how S. King is trying to show the worst part of a horror story - when love turns into bloodlust and the novel's character is completely defenceless against it.

One may wonder why S. King writes so much about children. An important reason is his view on child's thinking. 'King believes that it is important for the reader to cultivate the child's point of view . . You must have a child's ability to believe in everything ${ }^{54}$. This is why The Shining does not only show Danny's thinking. It also comes back to Jack's childhood, his relations with father and his memories that make him want to be a better father for Danny. It is a special measure making the reader feel like going back to being a kid, to thinking as a child. This stylistic feature connects all of the three novels discussed in this chapter. Carrie and The Shining were both featuring children or teenage characters. This is also an extremely important motif in another King's novel - It. Some readers claim that this is the best horror story written by modern master of horror. All of S. King's fears and obsessions reflect in this story ${ }^{55}$.

As already mentioned, in It $\mathrm{S}$. King offered his readers returning to childhood. Eleven-year-old children need to face the terrible clownmurderer. Human world order meshes up with the extra-terrestrial forces' order - the Good and the Evil. According to M. Kruszelnicki, it is not accidental that there is seven of children in this novel. 'Seven young emissaries of the Good bravely facing the terrifying avatars of the absolute Evil. How noncontingent is this number! Seven is the number of fullness and completeness consisting of the total of the lucky numbers: three (heavenly number) and four (earthly number) ${ }^{56}$ [translation mine].

Why did King choose children again to be his main characters? There are many fears that are common to kids, and that the adults do not believe in anymore. In this novel, greatest fears of childhood are real. A good example of such fear is shown in one of the scenes, when the boy is sitting on the bridge and moves his legs above the water: 'A hand closed around Eddie's foot . . . Urine spilled hotly down his legs and stained his jeans black in the moonlight. . . It was Dorsey. It was Dorsey as he had been buried. . . Eddieeee, his dead brother croaked, just like

${ }^{54}$ King, S., 2005. Danse Macabre, trans. P. Braiter, P. Ziemkiewicz. Warsaw, Prószyński i S-ka, p. 60.

${ }^{55}$ Gómez, T., 2008. Człowiek i twórca: Stephen King, trans. M. Mróz. Warsaw, MUZA SA). p. 102.

${ }^{56}$ Kruszelnicki, M., 2010. Oblicza strachu: Tradycja i wspótczesność horroru literackiego. Toruń, Wydawnictwo Adam Marszałek. P. 153. 
one of the dead people who were always coming back from the grave in the horror comics ${ }^{57}$. Every child is afraid of a cold hand coming from under the bed that will catch their leg at night. Adults know that it is a spoof, but if some unidentified thing touches their foot in the water, they often start to scream. King is aware of this fact - we grow out of our childhood fears, but many of them stay with us in a different form. "'The idea," he has said, "is to go back and confront your childhood, in a sense relive it if you can, so that you can be whole." We are haunted by our childhoods, by the important things we lost on the long walk to adulthood: the intensity of loves and fears, the talismanic rituals and objects of affection, and the moments of certain comprehension of our place in the scheme of things ${ }^{58}$. This special technique, a novelty in the genre in which mainly adults occur, has become an extremely important element of building his success as a writer. Adult readers go back to those beautiful times of being a kid, but they need to face their fears during this difficult but pleasant journey. 'The theme of IT was first expressed in King's short story The Boogeyman: "Maybe if you think of a thing long enough, and believe in it, it gets real. Maybe all the monsters we were scared of when we were kids, Frankenstein and Wolfman and Mummy, maybe they were real. Real enough to kill the kids who were supposed to have fallen into gravel pits or drowned in lakes or were just never found" "59. The author himself explained the idea: 'It's nothing but the Biblical idea that faith can move mountains and that faith proveth all things. So when this kid in IT believes that he is seeing the Mummy coming toward him across the ice of a frozen river, it really is the Mummy ${ }^{, 60}$. Children have greater faith than adults. It is easier for them to believe in monsters, ghosts and other creatures. However, this does not mean that King's books are for children. The characters of It come back to face the monster again as adults. The author is trying to show that faith is the key to horror stories: if the readers believe it could be true, it does not matter whether they are 8 or 68 . This stylistic feature is used in many of S. King's stories, and the motif of childhood is one of the author's favourite themes.

${ }^{57}$ King, S., 2011. It. London, Hodder \& Stoughton. P. 312.

58 Winter, D. E., 1989. The Art. Of Darkness: The Life and Fiction of the Master of the Macabre: Stephen King. London, Hodder \& Stoughton. P. 127.

59 Winter, D. E., 1989. The Art. Of Darkness: The Life and Fiction of the Master of the Macabre: Stephen King. London, Hodder \& Stoughton, p. 194.

${ }^{60}$ Winter, D.E., 1984. Interview with Stephen King. 


\section{CONCLUSIONS}

There are many factors that are important elements of S. King's writing style. Apart, they are nothing special, just some useful tips for people who want to become good writers. All together these elements create a unique, special style that represents the best horror writer in the modern world.

In his book On Writing King admitted that people who buy books usually do not care about the literary value of the novel. They do not really care about whether he is considered a great writer or just a writer whose style is nothing exceptional. What they care about is that his books can keep them intrigued and curious. 'People want an interesting story to take on a plane, something that will make them fascinated first, then implicate them and make them turn one page by another ${ }^{, 61}$ [translation mine]. His novels compete with TV and the Internet, and not many literary works can do that.

Examples from novels such as Carrie, The Shining and It were helpful in providing a stylistic analysis of S. King's way of writing. Several stylistic peculiarities that have become the author's identification mark have been analysed (S. King's way of introducing his personal beliefs, experience and fears into his fiction). S. King's novels and short stories contain multiple interesting themes, characters and symbols that tell us a lot about this popular author. Understanding his message hidden in many of his works is an important aim for literature and linguistics.

One thing that cannot be argued despite all of the good and bad opinions about King's writing is his standing out. A good summary on this field could be a fragment of The New Yorker article: 'There are lots of writers who tell it like it is, but only a few who, with such commitment and intensity, tell it like it isn't. King takes the weird and gives it weight. And yet, at the same time, his novels retain a lightness, a playfulness. They show us horrible things, but they also glow, I think, with King's joy - with his pleasure and exhilaration in imagining ${ }^{, 62}$.

\section{SUMMARY}

The article deals with the stylistic basis of Stephen King's horror novels. All in all, three of S. King's novels analysed above, as well as

\section{S-ka. P. 126.}

${ }^{61}$ King, S., 2001. Jak pisać: Pamiętnik rzemieślnika. Warsaw, Prószyński i

${ }^{62}$ Rothman, J., 2013. What Stephen King Isn't. Retrieved March 14, 2019 , from www.newyorker.com. 
many others, show many stylistic peculiarities of the author that are very interesting from the linguistic point of view. Many linguistic novelties in this field can be discovered. One of them is S. King's specific rhythm, strongly connected with narrative. Another one is related to the author's special ability of creating noteworthy characters and describing them. What is more, S. King's descriptions, dialogues, language and vocabulary all concur a specific style which is not common to other horror writers. Many repeatable themes of S. King's works also are a part of the writer's personal style, for many of them are strongly connected with his own life. The field of analysing S. King's writing style is very wide and many aspects can still be developed. One of these aspects is symbolism which will be studied in the following chapter.

\section{REFERENCES}

1. Anderson, J.A., 2017. The Linguistics of Stephen King: Layered Language and Meaning in the Fiction. Jefferson, McFarland.

2. Bloch, R., 1986. Monsters in Our Midst [in:] Miller C. \& Underwood T. (ed.), Kingdom of Fear: The World of Stephen King. Falmouth, Hodder \& Stoughton.

3. Ciabattari, J., 2014. Is Stephen King a Great Writer? Retrieved March 13, 2019, from www.bbc.com.

4. Gómez, T., 2008. Człowiek i twórca: Stephen King, trans. M. Mróz. Warsaw, MUZA SA)

5. Greeley, A. M., 1986. Stephen King's Horror Has a Healing Power [in:] Miller C. \& Underwood T. (ed.), Kingdom of Fear: The World of Stephen King (p. 19). Falmouth, Hodder \& Stoughton.

6. Indick, B.P., 1986. King as a Writer for Children. [in:] Miller C. \& Underwood T. (ed.), Kingdom of Fear: The World of Stephen King (p. 201). Falmouth, Hodder \& Stoughton.

7. King, S., 1986. The Horror Writer and The Ten Bears. [in:] Miller C. \& Underwood T. (ed.), Kingdom of Fear: The World of Stephen King. Falmouth, Hodder \& Stoughton.

8. King, S., 1995. Danse Macabre. Warsaw, Prószyński i S-ka

9. King, S., 1998. The Shining. Warsaw, Prószyński i S-ka

10. King, S., 2001. Jak pisać: Pamiętnik rzemieślnika. Warsaw, Prószyński i S-ka.

11. King, S., 2011. It. London, Hodder \& Stoughton.

12. King, S., 2011. It. London, Hodder \& Stoughton.

13. King, S., 2013. Carrie, trans. D. Górska. Warsaw, Prószyński i S-ka. 
14. King, S., 2013. Carrie, trans. D. Górska. Warsaw, Prószyński i S-ka.

15. Kruszelnicki, M., 2010. Oblicza strachu: Tradycja $i$ współczesność horroru literackiego. Toruń, Wydawnictwo Adam Marszałek.

16. Lovecraft, H.P. The Collour out of Space. Retrieved March 27, 2019, from https://repositorio.ufsc.br

17. Lovecraft, H.P. The Picture in the House. Retrieved March 27, 2019, from http://www.hplovecraft.com/writings/texts/fiction/ph.aspx

18. McDowell, M., 1986. The Unexpected and the Inevitable [in:] Miller C. \& Underwood T. (ed.), Kingdom of Fear: The World of Stephen King. Falmouth, Hodder \& Stoughton.

19. Romano, A., 2018. Stephen King Has Spent Half a Century Scaring Us, But His Legacy Is So Much More Than Horror. Retrieved April 4, 2019, from www.vox.com.

20. Rothman, J., 2013. What Stephen King Isn't. Retrieved March 14, 2019, from www.newyorker.com

21. Winter, D. E., 1989. The Art. Of Darkness: The Life and Fiction of the Master of the Macabre: Stephen King. London, Hodder \& Stoughton.

22. Winter, D.E., 1984. Interview with Stephen King.

\section{Information about the author: Liubov Didukh, $\mathrm{PhD}$,} Associate Professor at the Department of Foreign Languages and Translation Studies, Lviv State University of Life Safety 35, Kleparivska str., Lviv, 79007, Ukraine ORCID ID: https://orcid.org/0000-0001-8833-4571 


\section{TRANSCULTURATION, CONNECTEDNESS \\ AND "ALIEN" HOME AS AN ARCHETYPAL CONCEPT IN POST-POSTMODERN FICTION}

\section{Dmytro Drozdovskyi}

\section{INTRODUCTION}

Twenty-first century British literary fiction problematizes the concept of home as an essential element of the literary discourse. British authors (M. Hamid, Y. Owuor Adhiambo, etc.) who write about the lives of the characters from Africa depict the design of the "third countries" as dangerous for human beings. Immigration is, on the one hand, a psychological issue as it reveals the problem of leaving your own ethnical home. However, on the other hand, ethnical home for the characters is not a place of peaceful living but a territory involved in struggles and riots, war conflicts and various confrontations that reinforce the idea of migration and the concept of transcultural reality that has an impact also on the minds of the characters. This new reality is based on the idea to reach the level of life that enables the idea of happiness and peaceful coexistence, social career success and pleasures.

First, Home in the transcultural literary paradigm becomes "alien" and new unknown lands absorb the knowledge and experience, views and religious beliefs of the people who escaped from their homelands. British fiction problematizes in this was the idea of Home as an archetypal phenomenon as normally home was depicted as a place that formed the characters and their identities. Now, in the post-postmodern transcultural literary paradigm home is associated with pain and fear of being killed, s what the characters retells in I. Aliende's novel In the Midst of Winter (the author is not of British literature design, however, her novel is an important example to spotlight the discussed issue). The life of the woman characters in Latin American country represents the discourse of drugs traffics and human assassinations that demonstrate the idea of the "alien place" where the human life has no social value.

Secondly, outlining contemporary writings it is important to emphasize the concept of connectedness represented by Monica Germaná. The scholar analyzes the idea of "inner interior" in the post-postmodern British fiction paying attention to the fact that post-postmodernism represents the state of being tired of irony. Post-postmodernism is 
attentive to the inner bonds between the characters in the reality they construct physically or mentally. The idea of "true reality" becomes a challenge and an impossible goal for post-postmodern writings. The authors describe deep feelings and states like devastating or appalling determined by various encounters (terroristic attack, the image of the attacked airplane in the sky). As S. Vlacos states, "In present culture, however, the critical or ironic 'edge' associated with postmodernist antirealist techniques has fallen flat, so much so, that the devices of postmodernist anti-realism (those devices designed to shatter the realist illusion and to foreground the fictive status of the work question) are now submerged within a new and yet formally quite familiar mode of realism" ". Besides, the new trends in British fiction demonstrate the importance of Kant's philosophy that was debated and attacked in the British fiction of XX Century. "Where Kant had side-lined aesthetic experience to its own distinct realm of appearances and disinterested pleasures, the realist asserted the interconnection of that experience with knowledge of everyday praxis, championing the artwork's participatory role within everyday understanding and historical reality"2. However, I would state and I have already proved this thesis in my previous researches $^{3}$ that in post-postmodern fiction Kant's philosophy is interconnected with the realist searches of the everyday praxis and the understanding of live that the characters encounter each new day is a ground for deeper understanding of the reality. This search for "true reality" problematizes the concept of realism in the contemporary British fiction and outlines the necessity of new term for realistic writing determined by both Kant and positivism.

The representation of the concept of home interconnects with the idea of "true reality" and positivistic views as the displacement of this concept in the contemporary writing is a result of confrontations, weapon and war conflicts in African, Latin American or other Eastern countries. However, the understanding by the characters of the concept home in the new sociocultural paradigm (when new places become new homes)

${ }^{1}$ The Routledge Companion to Twenty-First Century Literary Fiction (2019). Eds. D. O'Gorman and R. Eaglestone. London-New York: Routledge, p. 103.

${ }^{2}$ Ibid. P. 101.

3 Drozdovskyi D. (2019). Dyskurs subiektnosti v anhliiskomu postpostmodernistskomu romani. [Discourse of Subjectivity in English Postpostmodern Novel]. Naukovyi visnyk Mizhnarodnoho humanitarnoho universytetu. Seriia: Filolohiia. Vypusk 38. P. 194-198. 
reinforces the necessity of the contemporary fiction in Kant's philosophy and the idea of the substantive knowledge. It is important to find the answer to the question what home means for the characters who live in the $21^{\text {st }}$ century and who had to escapee from their ethnical places associated with life threats and social conflicts.

Jennifer Hodgson in The Routledge Companion to Twenty-First Century Literary Fiction (edited by Daniel O'Gorman and Robert Eaglestone" in the chapter "Experiment" quotes Tom McCarthy's novel Remainder analyzing the feeling the narrator has after the encounter with the carrot ("It had texture; it had mass"4). The scholar adds: "These are fictions which describe a world where the real has already been thoroughly managed and mediated. Here characters confront the challenge of situating themselves in relation to a world made strange by unanthropomorphisable hypercapitalist and technocratic forces" ${ }^{\text {. }}$. Jennifer Hodgson argues that "Postmodern claims about the fictiveness of all truths" ${ }^{\prime 6}$. In the latter sentence she scholar quotes the words of the narrator from Adam Thirlwell's novel Kapow! who is ironic about the totality of postmodern irony ("convention' that is 'too convenient"",7). The British scholar underlines also Ben Lerner's novel Leaving the Atocha Station as "an example of how literature can work with ethical and political issues"8. In general, J. Hodgson, analyzing the contemporary experimental British novel, spotlights the reality searches of the post-postmodern characters drawing readers' attention to that fact that "David Shields' epoch-defining manifesto Reality Hunger (2010) argues that a deep and abiding need for the real is ill-served by mainstream fiction's 'pretense [sic!] of actuality" .

In the chapter "Realisms", represented in "The Routledge companion...", it's said that in the contemporary British fiction, the true representation of the reality is one of the most important modes. Such idea problematizes the concept of true reality in the contemporary fiction. Moreover, there are significant determinations of the importance of reality through the lens of astronomy, physics, etc., as there is a need to provide a

${ }^{4}$ The Routledge Companion to Twenty-First Century Literary Fiction (2019). Eds. D. O'Gorman and R. Eaglestone. London-New York: Routledge, p. 20 in the novel.

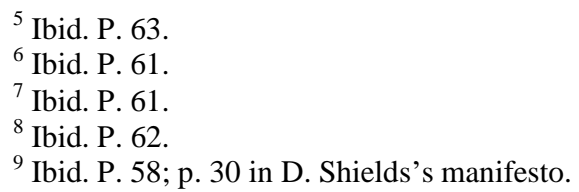


clear view of the Universe nature, and fiction these days has become an essential phenomenon that can deliver new knowledge (even in the alternative mode) using the paradigm of alternative reality. Sciences do not provide the complete look at the human being and the nature of human reactions, feelings, consciousness, etc. Fiction constructs alternative realities exploiting scientific facts as an essential element of the new post-postmodern outlook.

In the chapter "Autobiografiction" in "The Routledge Companion ...", Timothy C. Baker analyses David Shields's "Reality Hunger" manifesto (2010) drawing readers' attention to the fact that it's not important what is real in fiction but it is important what can cause experiencing of "authenticity"10. David Shields exploits the terms "deliberate unartiness", "the difference between fiction and nonfiction", etc.

Timothy C. Baker summarizes that as "James Wood comments in a review of Sheila Heti's How Should a Person Be? (2012) Shields's title is particularly apposite: '[r]ealism is perpetually hungry [...] because no bound manuscript can ever be 'real' enough' (Wood 2012). In a variety of forms, ranging from romans á clef and fictional autobiographies to fiction presented in the form of autobiographies, diaries, and memoirs, as well as texts that problematize all categorical distinctions, contemporary writers constantly renegotiate the value of the "real""11.

Sophie Vlacos, the author of the chapter "Realisms" in "The Routledge Companion ...", discusses the concept of Object Oriented Ontology $^{12}$ as a new vector for literary realistic paradigm of the postpostmodern fiction. Ontological mode of the reality becomes an essence in the post-postmodern literary paradigm in the contemporary British fiction. Ontological mode exploits the connections between the characters and the anthropocene phenomena taking into account the concept of "inner interior" which means the deeper bonds between things and human beings that cannot be explain in the traditional logical paradigm or using the traditional explanation methods.

Granted the diversity of approaches and mediums covered by this general inclination to think beyond the subject, 'contemporary realisms' seems an appropriate flexible term through which to explore their commonality and their literary repercussions. The suitability of this

\footnotetext{
${ }^{10}$ Ibid. P. 48.

${ }^{11}$ Ibid. P. 48.

${ }^{12}$ Ibid. P. 101.
} 
ambidextrous term is confirmed by the rise of a philosophically incongruous and yet historically consistent wave of literary humanism of 'New Sincerity', a mode of literary realism devoted to the material and phenomenological reality of human experience impelled by a similar fatigue with poststructuralist preoccupations ${ }^{13}$.

Thinking of these words by Sophie Vlacos, I have in my mind Olga Tokarchuk's recent Nobel lecture. The Polish author mentioned in her Stockholm speech (December 2019) the term "parable realism". Moreover, let me remind you also of R. Rucker's "A Transrealist Manifesto" in which the American scholar and writer proposes another form of "contemporary realisms ${ }^{14}$. In this way, S. Vlacos's position enables the term (or a paradigm) that coordinates various academic views and writers' manifestos regarding the new form of reality and its representations. Furthermore, this term 'contemporary realisms' demonstrate the importance of realistic tendencies and modes in contemporary fiction.

As the British scholars consider, "eighteen years after Brown's essay the discussions on the material essence of the things have become deeper" ${ }^{\prime \prime}$. Sophie Vlacos takes into account Bill Brown's manifesto "Thing Theory" (2001). The mentioned discussions have unfold the interest in realism and its representations in the post-postmodern fiction.

Contemporary British fiction and particular the novel (the notion "contemporary British novel" in the research is synonymous with the term "post-postmodern novel" that refers to novels written after 2000s: this peculiarity is represented in the contemporary compendia about the British fiction) and the American novel, for example, the I. Allende's In the Midst of Winter exploit to the motif of displacement.

'The term 'displacement' can name an affective state, a psychological mechanism and a physical experience. The interaction between these meanings of the word produces much of its richness and perhaps explains the frequency with which it occurs in contemporary scholarship attempting to grapple with the movement of people around the globe today, and with the legacy of the migrations of the past, both of which have involved violence, coercion and exploitation as well as hope, human ingenuity and the creation of new bonds, communities and

\footnotetext{
13 Ibid. P. 101.

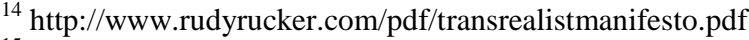

${ }^{15}$ The Routledge Companion to Twenty-First Century Literary Fiction (2019).
}

Eds. D. O'Gorman and R. Eaglestone. London-New York: Routledge, p. 100. 
cultures" $"$. Besides this long but effective definition (which can be of course developed and unfold), Emily Hogg, the author of the chapter "Displacement", writes that

Most obviously, displacement refers to the experience of being out of place geographically. $<\ldots>$

The concept of 'multiple displacement' - referring to a series of proliferating, different displacements, with shared historical roots - also has resonance beyond the Palestinian case, and it is useful to think about this term in relation to Dust, which is set in Kenya ${ }^{17}$.

Displacement as a theoretical concept that outlines and represents one of the key vectors for the transformation of the British novel has been analyzed in The Routledge Companion to Twenty-First Century Literary Fiction ${ }^{18}$ by Emily J. Hogg. In the chapter "Displacement", the author exploits the concept of multiple displacement based on the novel Dust (2014) written by Yvonne Adhiambo Owuor. Migration, terrorism, refugees are images that determine the thematic spectrum of the contemporary British novels written after 2000s, which re-reveal the transgression motif inherent in the post-postmodern novel and correspond it to the transculturation paradigm.

Moreover, the Ukrainian scholar T. Sverbilova is right in her definitions, following Wilson Harris and Jacques Derrida, that "transculturation does not erase differences between cultures, but involves them in the creative play process" $"$. This tendency is inherent in the postmodern novel, but it acquires new features and transformational representation in the post-postmodern paradigm. Stuart Hall in his book, "Familiar Stranger", notes that "he found displacement in the place of his roots" "20. "In Exit West, Mohsin Hamid explores the complexity of the relationship between home/security and displacement/vulnerability through his depiction of homely spaces" ${ }^{21}$.

${ }^{16}$ Ibid. P. 239.

${ }^{17}$ Ibid. PP. 239-240.

18 Ibid. PP. 239-249

19 Sverbilova T. (2019). Dyskurs transkulturatsii ta kulturnoi hibrydnosti yak predmet literaturnoi komparatyvistyky [Dosciurse of Transculturality and Cultural Hybridity as the Subject of Comparative Literature Studies]. URL: https://www.academia.edu/38002133/ДИСКУРС_ТРАНСКУЛЬТУРАЦІїТА_КУЛЬ ТУРНОї ГІБРИДНОСТІ.pdf (accessed 7 December 2019), p. 3.

${ }^{20}$ Hamid M. (2017). Exit West. New York: Hamish Hamilton, Riverhead Books, p. 243.

${ }^{21}$ Ibid. P. 243. 
The purpose of this research is to characterize the transformations of the archetype of Home in the post-postmodern novels.

\section{Transculturality and the Global Care Doctrine}

Transgression as a motive implies transcending boundaries, but in post-postmodernism, it is not just the exit and the extension of, but the search for meaning in the new reality (such as geopolitical) that the characters end up fleeing from their homes, as in the novel Exit West (2017) by Mohsin Hamid. The escape motive implements the discourse of transculturality, which is another factor in British post-postmodern novels. In addition, "the concept of transculturality can be used as a basis for contemporary comparative analysis of literature" 22 .

At the same time, the idea of transculturality in the novels is explicated when the characters enter a new country, form a new type of non-monoethnic identity. Often, the way of seeing sociopolitical reality in the novels is marked by the influence of the Global Care doctrine (Robinson 2008; Robinson 2013), which presupposes the key role of ethical principles in shaping contemporary global politics. Such a political doctrine, which has a significant impact on the formation of contemporary geopolitics, is developed on the basis of perceptions of relationships at the interpersonal level, which at the same time involves attention to such phenomena as geopolitical stereotypes, prejudices, etc. (for instance, the differences between the southern and northern types of mentality in Europe). According to T. Sverbilova, "special attention should be paid to the study of the dynamics of the formation of transcultural phenomenon in contemporary fiction - its component was previously studied through the prism of ethnicity, and aspects of transcultural that lead to the creation of a literary work that is thematic, problematic phenomenon" 23 .

The Global Care doctrine assumes that all players on the geopolitical scale are responsible for determining economic and social policies in the world: each player is responsible for the Other. One can agree that this political theory has at its core, in particular, an imagological basis, since relations between countries correspond to the basis of the study

${ }^{22}$ Sverbilova T. (2019). Dyskurs transkulturatsii ta kulturnoi hibrydnosti yak predmet literaturnoi komparatyvistyky [Dosciurse of Transculturality and Cultural Hybridity as the Subject of Comparative Literature Studies]. URL: https:/www.academia.edu/38002133/ДИСКУРС_ТРАНСКУЛЬТУРАЦІїТА_КУЛЬ ТУРНОЇ_ГІБРИДНОСТІ.pdf (accessed 7 December 2019), p. 1.

${ }^{23}$ Ibid. P. 9. 
of relations between people of different cultural regions. Global Care concepts are represented in contemporary post-postmodern British fiction. For example, Henry Perowne in I. McEwan's Saturday outlines terrorism as a challenge for the $21 \mathrm{st}$ century. However, the explanation of this phenomenon for the neurosurgeon, in the novel, has a medical assumption, which fully corresponds to the general tendencies of the post-postmodern novel (such phenomena are perceived and considered in the scientific paradigm, analytically and rationally (Drozdovskyi 2019) with biological and genetic explanations). T. Sverbilova states: "Homi Bhabha argues that world literature must be viewed through the lens of such common themes as historical trauma, slavery, genocide, exile, loss of cultural identity" ${ }^{24}$. Sharing this thesis, I note that to the list of concepts it is important to add the concept of "terrorism", which deals with the discourse of transculturation and is a factor in the development of Global Care doctrine.

In I. Allende's novel In the Midst of Winter, two opposite worlds are depicted: the American (Brooklyn) and Latin American, the latter is associated with drug cartels, human trafficking, slavery, etc. In the British novels, African countries whose characters leave their homes in search for a better economic fortune appear as a space for social problems and economic troubles. The shifting of cultural patterns, experiences, interaction of one type of identity with another defines the transcultural paradigm of the contemporary British fiction, in which characters often embrace the views inherent in the Global Care doctrine, in particular in terms of developing shared responsibility, and so on. In I. McEwan's Saturday, Henry is an example of a character who observes the world as an open space in which there are numerous links between East and West. Terrorism has become one of the key global issues, and Henry is trying to understand what causes terroristic attacks, which, at first, appear as a clash of worldviews and, accordingly, values formed by religion politics (in the Muslim East, cultural politics is often defined by religious doctrine, as Henry considers).

\section{Transculturality in Post-postmodernism: concepts and feelings of connectedness}

Terrorism, as stated in The Routledge Companion to the TwentyFirst Century Literary Fiction, has led to the formation of the separate genre paradigm in the contemporary novel "9/11". As Arin Keeble argues in the chapter "The 9/11 Novel".

${ }^{24}$ Ibid. P. 4. 
In mapping this conflictedness and charting the evolution of the 9/11 canon, I will also address the underlying question of what this body of texts is: a question of both classification and qualification" 25 .

The author adds that

'9/11 Novel' is often used interchangeably with 'post 9/11 novel' a term which is deployed to describe texts that engage centrally $9 / 11$ but also as a general catchall for novels written after the attacks. I understand $9 / 11$ and its aftermath directly ${ }^{26}$.

I would like to underline that A. Keeble analyses Saturday by I. McEwan explaining that this novel does not "engage with $9 / 11$ directly but" deals "centrally with terror and 'otherness' in the immediate af6tyermath" 27 .

The discourse of the "otherness" is an essential element to unfold the questions of transculturality in the contemporary British fiction. On the one hand, transculturality is an opportunity to redistribute knowledge, ideas, and open access to everything (in terms of geographical displacement, mobility, etc.). On the other hand, it is important to implement the concept of displacement in such a way that it creates the opportunity to perceive different memories, traditions, identities, expanding with the help of the Other limit of one's own perception. This process is often portrayed in novels as a process of the encounter, but one of the protagonists of the novel In the Midst of Winter considers the representatives of other cultures as carriers of experience that extend their own boundaries and knowledge about the world. The process of transculturation involves interchange and enrichment for all participants in the space of contacts. Moreover, "connectedness" is an important feature of the post-postmodern novel. Analyzing Ali Smith's novels, Monica Germaná states:

Significantly, while placing emphasis on the critical state of human relations in the twenty-first century, Smith's fiction also emerges as strongly life-assertive and redemptive, replacing the solipsistic of contemporary living with a new kind of emphatic connectedness that, arguably, constitutes a clear departure from the postmodern disaffection ${ }^{28}$.

${ }^{25}$ The Routledge Companion to Twenty-First Century Literary Fiction (2019).

Eds. D. O'Gorman and R. Eaglestone. London-New York: Routledge, p. 273.

${ }^{26}$ Ibid. P. 274.

${ }^{27}$ Ibid. P. 274

${ }^{28}$ Ibid. P. 100. 
The scholar defines this new feature of the British fiction represented in Ali Smith's novels as an important element in transformations of the postmodernism into post-postmodernism. If the postmodern characters revealed that state of tranquility as a way to escape from the outer chaos, then the post-postmodern characters are ready to be a part of the confrontation in the world trying to understand the deep (genetically determined, metaphysical) essence of such disorder that leads to human misunderstandings and conflicts. The post-postmodernism exploits the importance of true feelings and emotions, and meeting with the "otherness" provides this opportunity for both parts of the transcultural situation (even it is painful and unpleasant mentally or emotionally). In the novel Dust, the characters, "Struggling with this hostile school environment and with tensions in their family, Ajany and Odidi respond with dreams of movement and migration. $\langle\ldots\rangle$. The language of home, homelessness and longing is repeated in Selene and Hugh's story. Selene experiences an intense feeling of displacement in Kenya. <... . Ajany and Odidi, on the other hand, are citizens of the post-colonial nation-state their sense of belonging is not ethically compromised in the way that Hugh's is. Nonetheless, because the novel uses repeated words and phrases to link Ajany and Odidi's story with Hugh and Selene's, the reader becomes aware that Ajany and Odidi's homelessness is not simply a free-floating or individual sense of being dislocated or disconnected"29. Anyway, for many reasons the concept of connectedness is associated with the post-postmodern discourse, which is oriented to depict the deep pain and feeling of loss and disorientation the characters have and express because of the disordered world to which they belong and that a priory cannot be their home as a safety and comfortable place.

\section{Home as a dangerous place: transcultural transformation of Home archetype}

Speaking about cultural changes and transnational shifts of the characters, it is worth mentioning Hegel's idea associated with progress as a promotion in " +1 mode", when the characters develop morality, intelligence, etc. providing a general progression. However, transculturation processes in the real world, related in particular to the Global Care doctrine and represented in fiction, shift the notion of "my own" (safety) and "alien" (dangerous), inherent in the ancient and

${ }^{29}$ Ibid. P. 241. 
generally in traditional world, particularly in the aspect of Home as an archetypal phenomenon. The aforementioned archetype, which is one of the basic ones for human beings, is undergoing a transformation in the paradigm of post-postmodernism and is demonstrated in the transformed model in the contemporary fiction. Thus, home (the safety space) is now depicted as a space of dangers, and the other world gives the characters the opportunity to develop their intelligence, morality, culture in the new cultural spheres providing a form of new sincerity. I understand this notion as the sort of emotional response to the reality based on deep understanding of inner motivations of the characters. The scholars say that "As ideas of sincerity and authenticity are not unchanging but differ from culture to culture, a few examples will serve to demonstrate the differentiation between sincerity and authenticity as they currently exist before we return to literature. Firstly, assuming that authenticity really exists, it is possible to behave authentically, but insincerely. If your authentic self is a liar and you make a promise on which you subsequently renege, you were insincere but authentic. Secondly, in an example that I owe to Orlando Patterson, one can be sincere but inauthentic. Patterson notes that people may be authentically prejudiced but that this does not prohibit them from behaving according to negotiated standards of society, decency and self-consistency (sincerity) ${ }^{\text {"30 }}$.

For example, Ithaca sub-archetype (a variation of Home archetype), inherent in European literatures in general, is undergoing a transformation in the contemporary British novels. Odysseus's desire to get into his home is now replaced by the desire of the characters to find themselves by breaking ties with their own homes, which are economically uncomfortable. Going beyond home and realizing the ability of the characters to approach the formation of a new type of thinking (global), a new worldview and a new identity. In the novel Dust by Yvonne Edgambo Ovour, the heroine, Selena, cannot enter her own home because she tries to open the door with "the wrong key" "31. In this way, according to Emily Hogg, the novel demonstrates "the situation of homelessness" 32 ."Her inability to open the door symbolizes the extent to which she is out of place: he refrain throughout her time in Kenya is 'Let

\footnotetext{
${ }^{30}$ Ibid. P. 38.

${ }^{31}$ Owuor Adhiambo Y. (2013). Dust. Kwani Trust, p. 114.

${ }^{32}$ The Routledge Companion to Twenty-First Century Literary Fiction (2019).
} Eds. D. O'Gorman and R. Eaglestone. London-New York: Routledge, p. 241. 
us go back home' to England" "33. Let me repeat Emily Hogg's words from "The Routledge Companion" that give an important key to understanding the feeling of homelessness as a concept of the post-postmodern mind and an issue of the post-postmodern historical (transcultural) period: "Ajany and Odidi's homelessness is not simply a free-floating or individual sense of being dislocated or disconnected (of the sort that many young people the world over experience), but has a history, and is embedded in the political decisions and actions of the past" ${ }^{, 34}$.

Analyzing to the already mentioned image of Ithaca as a representation of the archetype of Home, I would like to note that this image also contains the motive of agon, rivalry and political conflict, which is associated with the travels of Odysseus, who, due to the will of the gods, was forced to abandon Penelope (his wife) and home. Conflict at home, clashes between different political groups, power struggles determine the image of home as an archetypal phenomenon for characters in the contemporary British novel, e.g. in Dust. The characters leave their home conflict space in which their lives are in danger to achieve new goals.

Transculturality is possible by the geopolitical Global Care doctrine (Robinson 2008; Robinson 2013), which provides the possibility of choosing another home and constructing a new identity, no longer grounded on a mono-ethnic basis. Undoubtedly, T. Sverbilova's assertion that new digital communications technologies and international network transcommunication communities question the existence of national cultures and nation-states and reinforce the concept of multiculturalism and culturalism to be reconsidered. "It is transculturalism that, according to many cultural researchers, remains the future" 35 .

T. Sverbilova argues that "cultural hybridization is defined as the blending of heterogeneous cultural elements leading to the emergence of new cultural forms as a result of the interaction of global, national and regional cultural influences and their processing at the local level. According to contemporary ideas, cultural influences are never

${ }^{33}$ Ibid. P. 241.

${ }^{34}$ Ibid. P. 241.

${ }^{35}$ Sverbilova T. (2019). Dyskurs transkulturatsii ta kulturnoi hibrydnosti yak predmet literaturnoi komparatyvistyky [Dosciurse of Transculturality and Cultural Hybridity as the Subject of Comparative Literature Studies]. URL: https://www.academia.edu/38002133/ДИСКУРС_ТРАНСКУЛЬТУРАЦЇ_ТА_КУЛЬ ТУРНОЇ_ГІБРИДНОСТІ.pdf (accessed 7 December 2019), p. 11. 
unidirectional, they can be reversed, and new cultural phenomena arising from the interaction of cultural forms of different origins and levels, as a rule, contain elements of all interacting cultures.

Caribbean philosophers have emphasized that hybrid identities and cultures should be seen not as a regional case but as the norm of a constantly moving, globalized world breaking away from its roots. This is an indispensable condition for the existence of contemporary cultural industries, despite the fact that belief in the existence in the contemporary world of national cultures contradicts such a means of being"36.

Hybrid identities have more creative potential than homogeneous cultures, so the new novels that exploit and reinforce the idea of transcending the borders and challenging the cross-boundaries experience provides an example of the creative benefit in the discourse of culture and literature.

However, the contemporary British novel is adopting a change of the notion of "one's own" and "alien" affecting the archetypal level of worldview by the characters.

As I have mentioned, the post-postmodern British novels represent a shift in the notion of the category one's own-alien. If traditionally, the category "one's own" was superimposed on the image of Home that has an archetypal nature and is associated with comfort and security, then in the contemporary British novels the category of "one's own" is portrayed as potentially dangerous. The characters who leave homes remain alive, while terrorists kill those who stay at home. I note that this shift is a consequence of the development of the multi/postcultural paradigm of the 21 st century British novel, in which one element of the image of the space are the topoi associated with the authentic home of the Other: for example, Kenya is an African country where human life is under a constant threat. If, in the traditional way, traveling to other worlds has been associated with being in danger, today this idea of traveling outside home is a subject to de(con)struction. In contemporary British literary theory, such a change is represented by the term displacement, which means "change/transformation/re-location". This concept is represented at the level of motif in a large number of contemporary British novels, which express a broader seek for multiculturalism and transculturality. However, a fixed feature, considered in particular in contemporary British

${ }^{36}$ Ibid. P. 11. 
theoretical works, as The Routledge Companion..., represents a change in the concept of the archetypes of Road and Home.

In post-postmodern novels, Road as an archetypal concept is associated with self-knowledge, the acquisition of new experiences and self-knowledge; instead, an authentic, ethnically determined home may pose a threat to basic values including life. The imbalance and disproportionality of the socio-economic development of the regions of the planet actualizes the problem of different treatment of value categories and of such category as respect for life and its protection as the highest value. The lack of democratic institutions and the unformed state itself are a factor in the displacement of traditional archetypal images.

The study of transculturation has become one of the priority areas of study in comparative literature studies. T. Sverbilova's "Discourse of Transculturation and Cultural Hybridity as a Subject of Comparative Literature" proposes a systematic and fairly comprehensive analysis of this phenomenon in the history of formation and features of functioning as a comparative problem.

Despite the fact that T. Sverbilova, following other researchers, start from the interpretation of transculturation as a linguistic phenomenon (and the question related to the perception of culture as a translational phenomenon), it is important to take into account the communicative specifics represented in the discourse of transculturality. In addition, at the present stage, the outlined phenomenon denotes not only the processes occurring in the border areas, but also it involves the loci and topoi associated with the former peripheral zones of the empires (such as the British one), as well as with the center of the territories related in the past to the Imperial Center (London). The scholar points out that "the category of cultural hybridization is used for border-type cultures, where a common identity is defined, not related to national, linguistic identity (e.g. Caribbean identity), 37 .

As already noted, now we observe the transformation of traditional ideas of the world, for which, for a considerable period, the perception of the home as a safety space was basic and opposed to an alien space associated with danger. On the other hand, going beyond home territory, represented in a number of contemporary British novels written after 2000 -s, recognizes the problem of displacement as one of the factors of transculturation.

${ }^{37}$ Ibid. P. 3. 
The characters of the contemporary novels leave home because it is associated with death. They leave their space and enter new worlds, metropolises constructed as immanently transcultural, in which the concept of identity is not a priori mono-ethnic. At the same time, there is no reason to state there is a dissolution of the ethnic or racial identity of the post-postmodern characters. Those who change their home spaces and go beyond the borders may become the source for new meanings that inspire others in order to search for the meaning of life taking into account those philosophical practices that are associated with the lives of these migrant or refugee characters. Chilean-American writer Isabel Allende presents such idea in the novel In the Midst of Winter. The wife of one of the main characters introduces a discourse of African beliefs and mystical practices of communication between the physical and metaphysical phenomena, and the husband is deeply influenced and inspired by these African beliefs.

Characters entering the metropolitan world (London, New York, etc.) open themselves to a new worldview, while at the same time they become a source for producing sensibilities, experiences, meanings that could be formed in Latin America, or Africa in the novels In the Midst of Winter by I. Allende and Dust by Yvonne Edgambo Owor. The characters' worldview conforms M. Foucault's thesis that we analyze the world in a way we are structured to see it. However, this postulate may be a subject to some changes: we see the world as we are taught to see it plus the way we see it when we are in a new socio-cultural environment. Besides, T. Sverbilova is right in pointing out that the processes of transculturation (and this ideas is shared and stated by F. Ortiz, $\mathrm{N}$. Vysotska, and others), are multilevel and multifaceted, in any case such a research should reveal the two-vector peculiarity of the phenomenon of transuclturality.

The discussed issues problematize another question in the contemporary British novel: the theory of transculturality is oriented toward the reconstruction the identity of the Other, however, it is much less attention paid to defining the identity of a "traditional" British person born in London. The identity of such characters is often portrayed through the contrasts with the identity of the Other, but now it has no inherently established parameters, which indicates the refusal of the contemporary British novel to postulate the idea of Englishness, which was already deconstructed in the postmodern stage. For Henry, in Saturday, his native London becomes a danger place because of the interference of another, more precisely the Alien, who is a representative of the Muslim religious 
fanatic views. Christopher, in M. Haddon's The Curious Incident of the Dog in the Night-Time, travels to London: the situation at the train station becomes one of the important factors in the character's development. Another type of urbanism, metaphorically speaking, of a different speed of transport and social connections, marks London in the novel.

\section{CONCLUSIONS}

The discourse of transculturation influences an array of themes and motifs explored in the contemporary English-language novels in the UK (Mohsin Hamid, Yvonne Edgambo Ovour) and the USA (Isabel Allende). The possibility of exploring a transcultural doctrine implies that every participant in the socio-cultural and political space has the value to form a common cultural environment, and everyone has the right to live a decent life in accordance with the concept of Global Care, which implies the ethical responsibility of all players for global transformations. At the same time, this discourse reinforces the ethics of the principles that underlie communication between different actors in the geopolitical and sociocultural space. The motif of migration determined by the threat to the lives of the characters within the home transforms the archetypal image of Home eliminating from it the notion of protection and security. Instead, the outer open space, which has a higher socio-economic level of development, is the foundation on which people from, for example, African or Latin American countries have the opportunity to provide a decent life. The discourse of transculturation, explicated in literary works, affects the transformation of the archetype Home (as well as the Road), which gives grounds for clarifying the theory of archetypes of the transcultural period characterized by hybridity, cultural heterogeneity, ethics of respect for the Other, experience to shape the concept of the planetary and global existence of mankind. Socio-political changes affect the space of literature affecting the change in such basic value concepts as the category of archetype.

\section{SUMMARY}

The theory of transculturality (F. Ortiz) is of particular importance in contemporary literary and cultural studies, the objects of which are hybrid cultural phenomena.

Moreover, transculturalism replaces multiculturalism, which does not imply the transfer of meanings, values, experiences, cultural phenomena, etc., but only confirms their presence in one geopolitical and socio-cultural field. Transculturality makes it possible to view cultural 
artifacts as a multifaceted phenomenon, marked by immanent heterogeneity and homogeneity, which at the same time provides particular creative and cultural significance of such phenomena. In Ukrainian and foreign literary studies, the outlines of transculturation are presented in the works of H. Bhabha, N. Vysotska, I. Orzhytskyi, T. Sverbilova, M. Tlostanova, and others. However, such studies have provided a historical overview of the forms of formation of the discourse of transculturation and the basic theoretical concepts (ideas) implemented in this discourse. The proposed research, which is an attempt to develop ideas that are relevant to the discourse of transculturation, spotlights the archetype of the Home as one influenced in contemporary British fiction by transculturation, which leads to the shifting of the immanent essence of this archetype in the contemporary British novel. Transformations are subject to such basic notions that correlate with the archetype of the Home as security, protection, comfort, and so on. In novels written after 2000-s, the characters leaving their ethnical space reach a new level of social security that guarantees the value of their own lives, while being within the locus of their home is marked by the dangers and potential threats to their lives. In the research, I deal with the transformation of the basic archetype of world literature in the paradigm of post-postmodernism. The replacement of the immanent features of the Home archetype is in line with the concept of displacement, which is widely represented in contemporary British theory of literature and British fiction.

\section{REFERENCES}

1. Allende I. (2018). Tam, za zymoiu [In the Midst of Winter]; trans. from Spanish by Serhii Borshchevskyi. Kyiv: Vydavnytstvo Anetty Antonenko, 2018. 360 p.

2. Drozdovskyi D. (2019). Dyskurs subiektnosti v anhliiskomu postpostmodernistskomu romani. [Discourse of Subjectivity in English Post-postmodern Novel]. Naukovyi visnyk Mizhnarodnoho humanitarnoho universytetu. Seriia: Filolohiia. Vypusk 38. P. 194-198.

3. Miroshnychenko L. Ya. Skeptytsyzm Sokrata i suchasnyi anhliiskyi roman [Socrates's Skepticism and the Contemporary English Novel]. Vid baroko do postmodernizmu: zbirnyk naukovykh prats. 2013. Vol. 17. № 2. P. 119-125.

4. Hamid M. (2017). Exit West. New York: Hamish Hamilton, Riverhead Books. 256 p.

5. Owuor Adhiambo Y. (2013). Dust. Kwani Trust. 385 p. 
6. Robinson F. (2013). Global care ethics: beyond distribution, beyond justice. Journal of Global Ethics. Volume 9. Issue 2: Critical Approaches to Global Justice: At the Frontier. P. 131-143. URL: https://www.tandfonline.com/doi/abs/10.1080/17449626.2013.818466 (accessed 7 December 2019). https://doi.org/10.1080/17449626.2013. 818466

7. Robinson F. (2008). The importance of care in the theory and practice of human security. Journal of International Political Theory. 4 (2). P. 167-188 URL: https://journals.sagepub.com/doi/abs/10.3366/ e1755088208000207 (accessed 7 December 2019).

8. Sverbilova T. (2019). Dyskurs transkulturatsii ta kulturnoi hibrydnosti yak predmet literaturnoi komparatyvistyky [Dosciurse of Transculturality and Cultural Hybridity as the Subject of Comparative Literature Studies]. URL: https://www.academia.edu/38002133/\%D0\% 94\%D0\%98\%D0\%A1\%D0\%9A\%D0\%A3\%D0\%A0\%D0\%A1_\%D0\%A 2\%D0\%A0\%D0\%90\%D0\%9D\%D0\%A1\%D0\%9A\%D0\%A3\%D0\%9B\% D0\%AC\%D0\%A2\%D0\%A3\%D0\%A0\%D0\%90\%D0\%A6\%D0\%86\%D0 $\% 87 \_\%$ D0\%A2\%D0\%90_\%D0\%9A\%D0\%A3\%D0\%9B\%D0\%AC\%D0 $\%$ A2\%D0\%A3\%D0\%A0\%D0\%9D\%D0\%9E\%D0\%87_\%D0\%93\%D0\% 86\%D0\%91\%D0\%A0\%D0\%98\%D0\%94\%D0\%9D\%D0\%9E\%D0\%A1\% D0\%A2\%D0\%86.pdf (accessed 7 December 2019).

9. The Contemporary British Novel since 2000 (2017). Ed. J. Acheson. Edinburgh: Edinburgh University Press. 214 p.

10. The Routledge Companion to Twenty-First Century Literary Fiction (2019). Eds. D. O'Gorman and R. Eaglestone. London-New York: Routledge. 474 p.

\section{Information about the author: Dmytro Drozdovskyi,} $\mathrm{PhD}$, Candidate of Philological Sciences, Academic Fellow of the Department of World Literature, T. Shevchenko Institute of Literature of the National Academy of Sciences of Ukraine 4, M. Hryshevskyi str., Kyiv, 01001, Ukraine ORCID ID: orcid.org/0000-0002-2838-6086 


\section{THE HUMAN REALM PERCEPTION IN SALMAN RUSHDIE'S NOVEL “TWO YEARS, EIGHT MONTHS AND TWENTY-EIGHT NIGHTS"}

\section{Tetiana Konovalenko}

\section{INTRODUCTION}

Salman Rushdie has always managed to astonish and to enchant his readers. Creative work according to the canons of magical realism gives the author the opportunities to invite his readers, at first sight, to the usual people's world, which otherwise appears to be characterized by supernatural features, inhabited with usual and unusual creatures, in which next to the ordinary life, absolutely supernatural events are happening. The occurrence of magic phenomenon or the appearances of supernatural creatures and even worlds in various literary works have their place at different stages of events development. In the novel "Two Years, Eight Months and Twenty-Eight Nights", since the first its line, it becomes clear that the story will be told about jinns and their nature, the devil is mentioned there as well. Further the author compares jinns and people, points at certain similar and different features. Besides, since the very beginning, Rushdie questions the future of the human realm depending on the triumph of the good or the evil: "...we have lived another thousand years since those days, but we are all forever changed by that time. Whether for better or for worse, that is for our future to decide" $"$.

It should be mentioned that there is a feature common for all Rushdie's literary works; it is the close link of the depicted in the novel events to the human history as well as the condemnation of the universal human drawbacks and sins.

The novel by Salman Rushdie "Two Years, Eight Months and Twenty-Eight Nights" dives the reader into the whirligig of events so that then to throw him or her out 'rather worn, bewildered and wholly happy

1 Rushdie, Salman (2015) Two Years Eight Months and Twenty-Eight Nights.New York: Random House. 
on the last page,2 . The fabric of the novel is woven through with the deep philosophic ideas such as the reason for being or the power of love.

This is the fairy-tale for adults and it runs about the war of jinns and people. The war is condemned as the phenomenon threatening the existence of the whole world and making the humanity lose all elements of humaneness. The tone of the narration is changing all the time: once it sounds as the motives and manner of eastern fairy-tales, especially closely to "The Thousand Nights and One Night", then the reader finds himself or herself on the pages of History course-book with bare facts on the events and attendant circumstances.

\section{Global Issues of the Human World Revealed}

The author's manner of writing in the genre of magic realism helps him to reveal the global problems of the human world and to strengthen the depiction colours he uses fairy-tale. Michiko Kakutani pointed that "magic realism - which combines heightened language with elements of the surreal - has tended to flourish in troubled areas of the world, or that many of its practitioners have sought to describe calamitous events that exceed the grasp of normal description". He calls it "a mirror of a reality in which the fantastic is frequently part of everyday life - a reality in which military death squads have effectively turned the word "disappear" into a transitive verb". The researcher emphasizes Rushdie's talent in using "the hallucinatory devices of magic realism to try to capture, metaphorically, the sweep and chaos of contemporary reality, its resemblance to a dream or nightmare" and maintaining "that the writer has a responsibility to tackle the larger issues of the day"3.

The versatile talent of Rushdie is in both his manner of writing and the ability to concentrate on the most urgent issues of the mankind. Rusdie's author's style in the novel "Two Years, Eight Months and Twenty-Eight Nights" amazes with its multilayer structure, as the story runs about itself and contains several stories at the same time. The readers from time to time find references or implications to paintings, films, other

${ }^{2}$ Yusefovich, Galyna (2016)Yest li zhizn posle non-fiction? Da! S romanami Salmana Rushdie i Davida Mitchella [Is there a life after Non-fiction? Yes! With novels by Salman Rushdie and David Mitchell]. Meduza [Jellyfish] (electronic journal). 10 Dec. Retrieved from: https://meduza.io/feature/2016/12/10/est-li-zhiznposle-non-fiction. (accessed 24 Dec. 2019).

3 Kakutani, Michiko (2018). Critic's Notebook; Telling Truth Through Fantasy: Rushdie's Magic Realism. New York Times 
literary or scientific works or characters or their authors (Voltaire's Dr. Pangloss, Aladdin's Lamp, Clark Kent, "Ghost Busters", Carroll's "Alice in Wonderland", Gogol's "Nose", Goya's Saturn, Fairy Queen Morgan and Wizard Merlin, Sinatra, Dearg-Due, Vlad Dracula, Mickey Mouse, Gandalf Gray, Rene Magritte's "Golconda", Homer, Isaac Asimov's "Foundation", Harry Potter and many others) as the author arranges for them to meet the characters of those books or remember those art and science representatives. Besides the literary intertextuality, the novel is characterized with historical relevance. The writer equates his artistic depiction of jinns' and people's war with the real wars in human history. He mentions even the Crimean annexation and ATO in Ukraine, as it goes: "crazed paramilitary jinn parasites in charge of tanks in Eastern Europe, shooting passenger aircraft out of the sky" 4 . In general, the writer shows the contemporary period of history as the worst of all, that is as the end of the world. The novel begins with the quotation by Francisco de Goya: "Fantasy abandoned by reason produces impossible monsters: united with her, she is the mother of the arts and the origin of their marvels." Though the second part of it emphasizes the condition for the existence of the real art, the author draws readers' attention to its first part, transforming it and writing it separately: "The sleep of reason brings forth monsters", warning the mankind about the loss of the control over such phenomena as violence, cruelty, terrorism, war.

The novel has deep philosophic content. The background story is devoted to philosophy as well, as it is about two philosophers Ibn Rushd and Ghazali, who have been arguing on the basic philosophy categories for a thousand years. It has been stated in literary critics before that "the polarity of characters is peculiar of most magic realist novels and chimeric prose" $"$. Ghazali is depicted as a negative character, extremely vain and lofty. We cannot say that Ibn Rushd is shown as an absolutely positive character, because he is just a common person having the drawbacks of common people. But his philosophy is deeply humanistic. On the existence of God he says that He is inexpressible, is beyond the borders of people's understanding. His wife Dunia responds to this his statement with a paradox: "Suppose I suppose that God may not exist. Suppose you make me suppose that 'reason,' 'logic' and 'science' possess

4 Rushdie, Salman (2015) Two Years Eight Months and Twenty-Eight Nights.New York: Random House.

${ }^{5}$ Konovalenko, T.V. (2017) Typology of Characters in Magical Realism and Chimeric Prose. Literary Imagination. Issue 3 (2), (November), Volume 19, 744-751. 
a magic that makes God unnecessary. Can one even suppose that it would be possible to suppose such a thing?" ". The main work by Ibn Rushd was 'The Incoherence of the Incoherence', in which he tried to "reconcile the words "reason," "logic" and "science" with the words "God," "faith" and "Qur'an," and he had not succeeded", and his book was set on fire as at that moment "that was what God decided"

The author contrastively compares histories of both jinns' and people' worlds. The existence of the jinns' world is languid, unchanging and dull. People's world is vice versa shown as the realm of constant changes, endless metamorphosis that was the cause of jinns intrusion into this dynamic world. Since the very beginning of the novel we see jinnia Dunia settle in the people's world, devote her life to philosopher Ibn Rushd, bear a great many of his children, though not being his lawful wife. And when he left her and she came back to her jinns' world, "the voyagers from the world of the jinn to ours became fewer in number, ... and the slits in the world became overgrown by the unimaginative weeds of convention and the thornbushes of the dully material"". Rushdie remarks that the mankind defense from the supernatural with their practicality and following their traditions. The situation cannot stay the same all the time, so a little bit later the real begin to interweave with the supernatural.

In the third millennium the bored jinns make up their minds to destroy the Earth and its population. On the one hand, the cause is their boredom and having nothing to do. On the other hand, this is caused by Islamic theologist Ghazali's making free the jinn and jinn's realizing the wish of Ghazali's soul a great deal of time after his death: to frighten the mankind so much that they would gather their wits and returned to the religion. After that the plot is developed according to Rushdie's usual manner of catching action spiced with good humour. Though the aftertaste stays rather anxious.

${ }^{6}$ Rushdie, Salman (2015) Two Years Eight Months and Twenty-Eight Nights. New York: Random House.

7 Rushdie, Salman (2015) Two Years Eight Months and Twenty-Eight Nights.New York: Random House.

8 Rushdie, Salman (2015) Two Years Eight Months and Twenty-Eight Nights.New York: Random House.

9 Rushdie, Salman (2015) Two Years Eight Months and Twenty-Eight Nights.New York: Random House. 
The author describes our world as the mystic illogic of accidental distribution. He writes the chaos and feeling of consistent unprotectedness of the modern mankind into the canon of fairy-tale, though, as we have already remarked, a little bit of its reality seems more and more real within every next chapter. Almost cartooned presentiment of the end of the world, flavoured with jokes and unpredictable realizations of the most fantastic literary plots. However, there is always the danger of chaos having its own algebra. In Rushdie's formula the readers can see thoughtless-fanatic nature of jinns, who are able to be implanted in people and to make them do endless harm.

Chimeric metamorphosis in the novel specify the time and space. The world of jinns, existing like out of the time, is shown in line with the chronological sequence of certain events in the people's world. As for the location of non-human world, it's not all that simple: it exists in the parallel space, from which sometimes the channels to the people's world appear, they are called just "wormholes". The impressive example of such a wormhole is the transfer of Jimmy Kapoor, while which he understands that there the universal laws stop functioning, and "the idea of place ceased to have meaning and was replaced by velocity"10. The author skillfully uses to the best effect the idea of such world's existence and uses the peculiar play on words, as "In that timeless time he had time to perceive that he had entered the transportation system of the world behind the veil of the real, the subcutaneous subway network operating just below the skin of the world he knew, which allowed such beings as the dark jinn and he had no idea who or what else besides to move at FTL speeds - speeds faster than light - around their lawless land for which the word land seemed inappropriate. He had time to hypothesize that for whatever reasonless reason this, the underground railroad of Fairyland, had been sequestered from terra firma for a long time, but had now begun to burst through into the dimension of the actual to wreak miracles or havoc amongst humanbeings" $"$.

But the author also emphasizes on the fact that the static world of the jinns' Fairyland is indeed empty and lacks the sense. This is because "It was human beings who allowed the jinn to express themselves, to create immense wealth for lucky fishermen, to imprison heroes in magic

10 Rushdie, Salman (2015) Two Years Eight Months and Twenty-Eight Nights.New York: Random House.

11 Rushdie, Salman (2015) Two Years Eight Months and Twenty-Eight Nights. New York: Random House. 
webs, to thwart history or enable it, to take sides in wars, between the Kurus and Pandavas, for example, or the Greeks and Trojans, to play Cupid or to make it impossible for a lover ever to reach his beloved, so that she grew old and sad and died alone at her window waiting for him to arrive" ". And the engine of this is that "the human way was doing, the human reality was alteration, human beings were always growing and shriveling and striving and failing and yearning and envying, acquiring and losing and loving and hating, and being, in sum, interesting"13.

Rushdie multilaterally covers the issues of the mankind's existence, their philosophy of life, positive features, drawbacks and sins and all that is on the way of mankind's historical development and can cause either the complete degradation or the complete destruction.

The writer actively works out the philosophic range of issues and usually whirls it into the complicate curl and emphasizes the complexity of those issues as in this extract: "The existence of the jinn posed problems to moral philosophers from the beginning. If men's deeds were motivated by benevolent or malignant sprites, if good and evil were external to Man rather than internal, it became impossible to define what an ethical man might be. Questions of right and wrong action became horribly confusing" "14. Further it runs about moral confusion of the epoch and a lot of work for students of morality. The writer's position is precisely clear, Rushdie ruthlessly exposes hypocrites and canters. To continue this thought, the author offers the theory that "in the old days before the separation of the Two Worlds, they say everyone had his or her personal jinni or jinnia whispering in an ear, encouraging good deeds or bad" "The matter is that people are not to blame for their deeds; the responsibility is on the jinns. The author's open irony emphasizes the hypocrisy of human nature and avoiding their responsibility for their doings. Besides, the issue is covered on the global level, as it goes about wars and conflicts.

12 Rushdie, Salman (2015) Two Years Eight Months and Twenty-Eight Nights. New York: Random House.

13 Rushdie, Salman (2015) Two Years Eight Months and Twenty-Eight Nights. New York: Random House.

14 Rushdie, Salman (2015) Two Years Eight Months and Twenty-Eight Nights. New York: Random House.

15 Rushdie, Salman (2015) Two Years Eight Months and Twenty-Eight Nights.New York: Random House. 
This is the novel-parable on the eternal love and its opposition disability to love, on turning the wisdom into scholasticism, and the belief into fanaticism. The author says: "...that to tell a story about the past is to tell a story about the present. To recount a fantasy, a story of the imaginary, is also a way of recounting a tale about the actual ${ }^{16}$. As it is stated in the novel review, "It is the utopia vice versa: the story written by the name of our far and mysterious predecessors about our epoch deranged time, the time of worders", and in one more it is precisely pointed that "the author so strongly twirled and spinned - and the fiction interweaved with the reality, the past, future and our present with all its problems: bribery, corruption, treachery, murders, ruinous habits...". The author chooses the cruel jinn Zumurrud to say: “... fear and greed, are the tools by which these insects (people) can be controlled with almost comical ease" 17 .

With the precisely professional touches, the writer outlines such problems of society as "American crazy" and the terrible consequences of its degradation: "shooting-kids-at-school or putting-on-a-Joker-mask-andmowing-people-down-in-a-mall or just plain murdering-your-mom-atbreakfast crazy". Here Rushdie explains the cause of all that craziness Second Amendment crazy - usual everyday craziness, starting to be the norm. He speaks of quite real things, realism of our society and our life the Second Amendment to the Constitution of the USA: "A well regulated Militia, being necessary to the security of a free State, the right of the people to keep and bear Arms, shall not be infringed"18. The reader also encounters with other deeds and events which trespass against all the human principles of peaceful existence of the mankind: "knife crazy", "the knockout-game type of crazy that persuaded young black kids it was cool to punch Jews in the face", "drug crazy and politician crazy and Westboro Baptist Church crazy and Trump crazy", "9/11 crazy". To

16 Rushdie, Salman (2015) Two Years Eight Months and Twenty-Eight Nights. New York: Random House.

17 Rushdie, Salman (2015) Two Years Eight Months and Twenty-Eight Nights. New York: Random House.

${ }^{18}$ USA Government (2017) Bearing Arms.Second Amendment. Constitution annotated. 03 Oct. Retrieved from: https://www.congress.gov/content/conan/pdf/ GPO-CONAN-2017-10-3.pdf 
summarize the idea of the mankind going crazy, Rushdie ends this extract with the phrase: "The devil was on the loose",

The deep philosophic wisdom goes through the whole novel. A lot of attention is paid to the analysis of separate actions of the mankind representatives, the regularities of their development, opinions on their lives and the laws of existence, making a mark. Once Mr. Geronimo was written to in a letter by his father: "You'll never amount to anything if you can't stick to anything". But the man remembers his father's words when his legs unstuck in the grounds of La Incoerenza and he is levitating all the time. Ironically he comments: "The old man knew what he was talking about". This is the hint to the all people on the Earth. At the end of the novel, when most people are levitating, i.e. unstuck in the ground, there is "the separation plague" told of and there are the examples of "a noticeable separation of writers from their subjects" in the area of literature, "the separation of causes and effects" in the area of science, "the separation of words and meanings", "the growing separation of the rich from the poor", "a spate of marital separations", end of old friendships. Here the authors uses a kind of zeugma, combining differentlevels things, concrete and abstract, which belong to quite different categories and spheres.

The issues of migration and migrants destinies are revealed in the novel. Thus, Mr. Geronimo thinks on that he "could have roots spreading under every inch of his lost soil, his beloved lost home, that he could have been a part of something, that he could have been himself, walking down the road not taken, living a life in context and not the migrant's hollow journey that had been his fate" 20 . We can see the tragedy of the life of a migrant which is usually more a regularity than a peculiarity. The author demonstrates the wild and cruel laws of living in the people's society: the people who are less protected socially become the targets for people's finding faults with them and making them even unhappier.

Ye.Yu. Chemiakin points that in postcolonial writers' novels there "appears the character belonging to several axiological systems, he

19 Rushdie, Salman (2015) Two Years Eight Months and Twenty-Eight Nights.New York: Random House.

20 Rushdie, Salman (2015) Two Years Eight Months and Twenty-Eight Nights. New York: Random House. 
accepts them and makes himself enriched"21. He analysed the character of a multicultural person in previous novels by Rushdie and other writers, pointing that Rushdie himself was a migrant so he described real emotions, hesitations, sufferings he experienced himself. The scientist points that Rushdie's books are the mixture of fiction and magic with political satire.

So, the appearance of "the machine of the future" in the novel is not accidental. It was thought up by the government of the country to make the people forget about their needs and interests and fully devote themselves to "the machine of the future". Ordinary people become blind and deaf, they do all they are told to do until one day, one of the men was visited by a jinn and was endued with the ability to see what was happening. At that moment the delusion that the machine is building the future was stopped. The people understood that they had been deceived. This story in story represents politicking and populism and reveals the lie, which is brought to the ears of ordinary people by the politicians, who manipulate the society.

The United States President within the described period is shown as a positive, charismatic personality, although not successive in the struggle against jinns and becoming "a president of empty words", "as many of them are, as they all have been, for so very, very long" ${ }^{\text {"2 }}$. Here we can clearly observe the sarcasm on people's losing trust to their presidents and governments.

It also runs on the people's attitude to the information. "In her (Storm Baby) illustrious memory we refuse to allow truth to become "truth", 23. Misinterpretation of information often occurs in mass media, public reports, and to make it worse it becomes the weapon in "the information war" of mankind against themselves. Beyond that the author hints on rewriting pages of mankind's history. The weak politicians are eager to make their mark on the world not by doing something important and necessary, but by rewriting the course-books in History.

21 Chemiakin Ye. Yu. (2011) Obraz multiculturnogo cheloveka v postcolonialnom diskurse [The character of a multicultural man in the postcolonial discourse]. History Annual. P. 25-34.

${ }^{22}$ Rushdie, Salman (2015) Two Years Eight Months and Twenty-Eight Nights.New York: Random House.

23 Rushdie, Salman (2015) Two Years Eight Months and Twenty-Eight Nights. New York: Random House. 
One more issue is arisen by the writer and it is the power of money and it significance in the life of some people. Especially brightly we can see the character of Sanford Bliss through such trifles as: "He (Sanford Bliss) also believed in numerical superstitions, such as the idea that round numbers were unlucky, you never charged ten dollars for a bag of feed, you charged $\$ 9.99$, and you never gave a man a hundred-dollar tip, but always one hundred and one" 24 . The author says that "there wasn't a line of poetry in his head but every dollar figure he'd ever encountered was neatly filed away and readily accessible" 25 . He was a man who "encountered the extraordinarily un-American idea that reality was not something given, not an absolute, but something that men made up, and that values, too, changed according to who was doing the valuing" ${ }^{26}$. And at this moment there appears the continuation of the novel's beginning, represented in Francisco deGoya's quotation: "If zero is the point of sanity at which two plus two always equals four, and one is the fucked-up place where two and two can add up to any damn thing you want them to be"... "then, ..., I'm sorry to tell you that we are currently located somewhere around zero point nine seven three,"27. This is one more hint as for mankind's coming to the critical point of existence.

\section{Rushdie's Means of Making Realism Magic}

The magic of figures is included into the title of the novel "Two Years Eight Months and Twenty-Eight Nights", which is an allusion to "One Thousand and One Nights" and if counted will do the same number of nights. But this number is throughout in the novel while being counted as the same number of days, at first beginning from Ibn Rushd's exile till his return to the court of Caliph Al-Mansur. Nevertheless while this period of time Ibn Rushd was staying with Dunia, whom he was telling his stories at nights, here we can see the hint on one thousand and one nights. Later this number will appear in Mr. Geronimo's life whose wife perished in two years, eight months and twenty-eight days sharp since he

24 Rushdie, Salman (2015) Two Years Eight Months and Twenty-Eight Nights.New York: Random House.

25 Rushdie, Salman (2015) Two Years Eight Months and Twenty-Eight Nights.New York: Random House.

26 Rushdie, Salman (2015) Two Years Eight Months and Twenty-Eight Nights.New York: Random House.

27 Rushdie, Salman (2015) Two Years Eight Months and Twenty-Eight Nights.New York: Random House. 
had begun to work at "La Incoerenza". The author summarises in the following way: "One thousand days and one day. There was no escape from the curse of numbers" 28 .

By the way, the thought of round numbers bringing misfortune goes through the whole novel the red line and the writer for sure does not uses round numbers in it. So, Ibn Rushd awoke after almost one thousand years' lying forgotten in one hundred and one days after the great storm. While arguing with Ghazali he speaks of possibility for religion shriveling away in a thousand and one years and beginning to live in God's truth.

Instead the reader can watch the terrible events happening in one hundred and one nights after the storm when in Jimmy Kapoor's room there appears a jinn who declares that he is the very person to "have danced Time and Space into being" 29 . He also informs on the fact that the portal is "busted open" and "border between what imagineers are imagining and what imaginees are desiring is leaky now" and through the wormholes the jinns will easily come to the human world and will be taking over and it is sure for "hundred and one percent" and he tells Kapoor to "forget about it" 30 .

Describing some supernatural events is accompanied with the author's beliefs on people's attitude to them and generally to real and unreal phenomena, as it runs in the extract where a new character appears - Baby Storm: "...our ancestors realized that many of them had abandoned the laws of realism long ago and felt at home in the more glamorous dimensions of the fantastic" ${ }^{\text {". }}$. At the same time we can see the worldview of Rosa Fast, the honest politician who used Baby Storm's unique abilities for identifying and revealing the lie and hypocrisy, told about the baby: "...We came into office to clean this place up... and chance has given us the human broom with which we can sweep it clean" ${ }^{\prime 3}$. There is a remark on Rosa's being an atheist who believes in miracles. Since the very beginning she understands the Baby Storm's

28 Rushdie, Salman (2015) Two Years Eight Months and Twenty-Eight Nights. New York: Random House.

29 Rushdie, Salman (2015) Two Years Eight Months and Twenty-Eight Nights. New York: Random House.

30 Rushdie, Salman (2015) Two Years Eight Months and Twenty-Eight Nights. New York: Random House.

31 Rushdie, Salman (2015) Two Years Eight Months and Twenty-Eight Nights. New York: Random House.

32 Rushdie, Salman (2015) Two Years Eight Months and Twenty-Eight Nights. New York: Random House. 
mission in the human world, so her ongoing influence on the human history running is called "events of a new kind, events of a type we would have described until very recently as fantastic and improbable" 33 .

The miracles continue to happen to both certain people and the global community. The individual influence can be seen from the small situation when the woman haunted by a rapist turned into a bird or the pervert peeping a celebrity turned into a deer as well as mass metamorphosis when the clothes of all people, present in the city square, disappeared and everything they had with them fell on the ground. Though this everything is presented with both: usual little things (cellphones, pens, keys, credit cards, currency, condoms, women's underwear, guns, knives, the phone numbers of unhappily married women, hip flasks, masks, cologne, photographs of angry daughters, photographs of sullen teenage boys, breath-freshening strips, plastic baggies containing white powder, spliffs, lies, harmonicas, spectacles, bullets) and quite immaterial things such as sexual insecurities, inflatable egos and broken, forgotten hopes ${ }^{34}$. The writer supports the fact that nothing is secret, that shall not be made manifest, described in the Bible. The whole situation reveals not only humans' physical nakedness but also and especially the moral one.

The reader is introduced to the reconceptualisation of reality perception since "things had reached a point at which only science fiction gave us a way of getting a handle on what the formerly real world's nonCGI mundanity seemed incapable of making comprehensible"35. All people who stayed alive after being struck with a lightning were considered to be "persons of interest". The reality interweaves with the fiction, so we can see that calling a jinn with rubbing a lamp becomes quite a usual event but not a wonder. The humanity feels difficult to learn to live in the epoch of wonders. This author's opinion appears to be revealing the humanity's secrets which are much better to remain secret as they demonstrate all sins and drawbacks of the humanity. As Anne Hegerfeldt pointed, marginalization is one of the society issues revealed in magic realist novels: "in order to level the social and cultural hierarchy

33 Rushdie, Salman (2015) Two Years Eight Months and Twenty-Eight Nights. New York: Random House.

34 Rushdie, Salman (2015) Two Years Eight Months and Twenty-Eight Nights. New York: Random House.

35 Rushdie, Salman (2015) Two Years Eight Months and Twenty-Eight Nights. New York: Random House. 
that is colonialism's (patriarchy's/ racism's/chauvinism's/...) legacy, magic realist fiction takes on the perspective of the hitherto oppressed, thereby endorsing their world view as a valid alternative to the dominant outlook $^{36}$. In this genre literary works we can surely observe the authors' sympathy to those who differ from the vast majority and "other marginalized world views are similarly revalued as important contributions which should be taken into account by dominant discourses $^{37}$.

For the brighter picture of the background of endless wonders era, Rushdie uses a number of allusions: "In a Romanian village a woman began laying eggs. In a French town the citizenry began turning into rhinoceroses. Old Irish people took to living in trash cans. A Belgian man looked into a mirror and saw the back of his head reflected in it. A Russian official lost his nose and then saw it walking around St. Petersburg by itself. A narrow cloud sliced across a full moon and a Spanish lady gazing up at it felt a sharp pain as a razor blade cut her eyeball in half and the vitreous humor, the gelatinous matter filling the space between the lens and the retina, flowed out. Ants crawled out of a hole in a man's palm"38. Here the author gives the examples from various world-known literary works to prove that all those wonders were the results of jinns influence.

The poetics of Salman Rushdie's novel under consideration proves to be an extraordinary part of author's individual style. Sometimes it is difficult to define what stylistic device or figure has been used by the author as he involves the richest stylistic potential of a literary language. For instance the depiction of cautious Mr. Geronimo who foresaw that "the fabric of society to tear and disintegrate, who knew that superglue could be used to hold cuts together, who did not trust human nature to build solidly or well" 39 . This extract is fortified with the combination of metaphor and irony which is spread further to tell about Mr. Geronimo’s

${ }^{36}$ Hegerfeldt, Anne (2002) Contentious Contributions: Magic Realism Goes British. Janus Head: Journal of Interdisciplinary Studies in Literature, Continental Philosophy, Phenomenological Psychology, and the Arts, 2002, 5 (2), pp. 62-86.

${ }^{37}$ Hegerfeldt, Anne (2002) Contentious Contributions: Magic Realism Goes British. Janus Head: Journal of Interdisciplinary Studies in Literature, Continental Philosophy, Phenomenological Psychology, and the Arts, 2002, 5 (2), pp. 62-86.

38 Rushdie, Salman (2015) Two Years Eight Months and Twenty-Eight Nights. New York: Random House.

39 Rushdie, Salman (2015) Two Years Eight Months and Twenty-Eight Nights. New York: Random House. 
superstitions and about the fact that in the USA "wicked spirits lived in trees so it was necessary to knock on wood to drive them out, whereas British tree-spirits (he was an admirer of the British countryside) were friendly creatures so one touched wood to get the benefit of their benevolence" ${ }^{, 40}$. It is quite unexpected episode where there is the transfer from Mr. Geronimo's character description to the percertion of his levitation state as leaving God and making the corresponding conclusions as for his further living: "If you walk away from God you should probably try to stay in the good books of Luck"41. The writer uses here the personification, giving the luck the importance of new God who will be able to lead Mr. Geronimo in his further life.

The personification as well as the irony is often used by the author in the novel. These two stylistic devices are rather often used together, for instance: "as if the storm was telling our ancestors, Fuck you, I'm buying the island back" 42 . In this sentence we see the combination of comparison with personification to emphasise that there is nothing happening accidentally, that everything has its causes and consequences.

The author seems to accidentally use the return allusion when tells about creation of a new intellectual group consisting of writers including magic realists. Rushdie's self-irony sounds quite clearly they are mentioned in the same line with idiot movie actors and renegade theologians. General binary opposition "religion - science" acts throughout the whole novel. The question of eternal struggle of these concepts is shown by the author. He depicts the humanity tending to the extremes often not being able to find the golden middle. Thus, we can see that the levitation called by the author "a previously unknown virus: a gravity bug", presents an issue for Mr. Geronimo who tries to explain it and does not know how to do that whether by means of science or religion. He founds the explanation about gravitons in quantum physics, a fundamental science, but this theory appears to be a supposition only which has no confirmation. He continues to study the science and look for the causes of his state and runs across "the language of creation", which cannot be understood by an ordinary person: "isospin doublet, Noether's

40 Rushdie, Salman (2015) Two Years Eight Months and Twenty-Eight Nights. New York: Random House.

41 Rushdie, Salman (2015) Two Years Eight Months and Twenty-Eight Nights. New York: Random House.

42 Rushdie, Salman (2015) Two Years Eight Months and Twenty-Eight Nights. New York: Random House. 
theorem, rotation transformation, up and down quarks, Pauli exclusion principle, topological winding number density, De Rhamcohomology, hedgehog space, disjoint union, spectral asymmetry, Cheshire Cat principle" $" 43$. Rushdie expresses sarcasm on the scientific language which remains beyond people's comprehension. He contradistinguishes science and needs of ordinary people, trying to remind that the science should serve to those people's needs. He mocks at scientists' trying to transfer the science into the extraordinary complex semantic field. After studying the crabbed books Mr. Geronimo realizes that his mind as well as body is getting off the ground.

The humour is present in a number of novel pages. The author's comparisons and similies are especially refined. It can be seen from the fragment where Rushdie tells about the rareness of such cases when jinnia could bear human children and compares it with "That would be as if the breeze were to be impregnated by the hair it ruffled and gave birth to more hair. That would be as if a story mated with its reader to produce another reader" ${ }^{34}$. He speaks of a unique ability of Dunia to bear a great many of Ibn Rushd's offsprings. Some other quite unusual comparisons make a reader smile: "had she produced offspring the way Henry Ford learned to produce motor cars, the way Georges Simenon wrote novels, which is to say, like a factory, or industriously" 45 . Later on the jinnia's maternal abilities will help half-humans-half-jinns to save the human world from annihilation. Dunia appealed to her descendants to find jinni within themselves, because it was the only fact which could help them to save the world they were living in.

Description of all supernatural events or things is supplied with author's humoristic comments. In such a way is described a situation when Dunia flied on her magic carpet into another apartment and appeared in front of Blue Yasmeen and said that she preferred not to use them as "their blasted positioning system is always going wrong"46.

43 Rushdie, Salman (2015) Two Years Eight Months and Twenty-Eight Nights. New York: Random House.

44 Rushdie, Salman (2015) Two Years Eight Months and Twenty-Eight Nights. New York: Random House.

45 Rushdie, Salman (2015) Two Years Eight Months and Twenty-Eight Nights. New York: Random House.

${ }^{46}$ Rushdie, Salman (2015) Two Years Eight Months and Twenty-Eight Nights. New York: Random House. 
The author also uses irony in other cases when he reveals his characters' emotions. When Mr. Geronimo, an earthling man, became the victim of a gravitation deviation and tried to touch the ground without effect, Miss Alexandra Bliss Farina "was watching him through groundfloor French windows with tears streaming down her beautiful young face and something else flowing from her eyes that he couldn't make out. It might have been fear or shock. It might even have been desire" ${ }^{\text {. The }}$ author in some way ironically combines practically incompatible emotional states of the Lady Philosopher.

Irony often turns into sarcasm, especially when it runs on the humans' sins in general or on some separate people's ones. The introduction to the story of Mr. Geronimo's appearance in the world is the preface about people easy going away from such important things as honor, morality, good judgment, and truth. Later on the reader learns about the birth of "the illegitimate son of a firebrand Catholic priest" 48 who could not be given his father's surname to follow the decency. Mr. Geronimo is shown as a deeply miserable person who has neither Motherland nor father's care and cheer that emphasise the causes of his being unfortunate. In a sarcastic comparison combined with antithesis it is expressed that the father appeared as alien to him "as Martians or reptiles, but was also as close as blood could make him" 49 . Father Jerry's character features are described rather contradictory: "the neighborhood's leading matchmaker and its benevolent tyrant, a conservative of the right type $", 50$. The use of oxymoron helps the writer to depict this character more concisely and to demonstrate his own attitude to such actors of society ideals. Besides, he shows that it often can be observed that such people have rather happy living, as Father Jerry was so big authority for the people that "nobody made a fuss when he surreptitiously (meaning that everyone knew about it) made a match for himself with a grave-faced stenographer" and became "a little less than perfectly celibate" ${ }^{51}$. Ironical

47 Rushdie, Salman (2015) Two Years Eight Months and Twenty-Eight Nights. New York: Random House.

48 Rushdie, Salman (2015) Two Years Eight Months and Twenty-Eight Nights. New York: Random House.

49 Rushdie, Salman (2015) Two Years Eight Months and Twenty-Eight Nights. New York: Random House.

50 Rushdie, Salman (2015) Two Years Eight Months and Twenty-Eight Nights. New York: Random House.

51 Rushdie, Salman (2015) Two Years Eight Months and Twenty-Eight Nights. New York: Random House. 
remark in brackets characterizes the people surrounding such a "devoted" priest. But fortunately there is no projection of father's character on Mr. Geronimo, there is only cause-and-effect relationship with his worldview.

The author's words about the motto of the whole humankind sound sarcastically: "No good deed goes unpunished"

Casterbriges smile is described with sarcasm as well: "His smile was a thing of menacing, almost feral sweetness, a smile that could bite your head off. His politeness was terrifying" $" 53$.

Mr. Geronimo's character is depicted as a charismatic personality in spite of being unsociable, influencing nobody, having nobody to follow. Nevertheless he is characterized with positive features and fixed on the soil very much. He even often thought of himself "as a plant, perhaps even as one of those man-plants born of sexual congress between a human being and the earth himself; and, consequently, as the gardened rather than the gardener. He placed himself in the soil of time and wondered, godlessly, who might be gardening him. In these imaginings he cast himself always among the rootless plants, the epiphytes and bryophytes, who must lean upon others, being unable to stand alone. So he was, in his own fancy, a sort of moss or lichen or creeping orchid, and the one he leaned upon, the gardener of his nonexistent soul, was Ella Manezes. His loving and much-loved wife" ${ }^{\text {"54 }}$. Later, after his wife's death he considered his gardened plants to contain the spirit of his deceased wife. When he had to cut his hair on his own, he called himself a gardener of his own head. So, we can see that he had a sense of humour. Though he seemed a person otherworldly but he rather realistically considered his possibilities and thought of the Fortune as "that merciless hag" "55.

He felt himself unnatural but hadn't suspected yet that he did not belong to the plants, but to much more supernatural creatures - jinns. His wife Ella noticed that he smelled like smoke, that "in the throes of his passion the edges of his body softened, became blurry, so that her body

52 Rushdie, Salman (2015) Two Years Eight Months and Twenty-Eight Nights. New York: Random House.

53 Rushdie, Salman (2015) Two Years Eight Months and Twenty-Eight Nights. New York: Random House.

54 Rushdie, Salman (2015) Two Years Eight Months and Twenty-Eight Nights. New York: Random House.

55 Rushdie, Salman (2015) Two Years Eight Months and Twenty-Eight Nights. New York: Random House. 
could melt into his" ${ }^{\text {} 56}$. Here the author does not use the metaphor he just writes in the style of magic realism, as Geronimo is the descendant of jinnia Dunia, a representative of Duniazat. When Dunia lived with Ibn Rushd he did not noticed anything strange in her, but when she appeared in front of him in almost a thousand-year period after his death and confessed about her being a jinnia, he remembers that sometimes "she had looked a little smudged at the edges, as if she were drawn in soft charcoal. Or smoke" ${ }^{, 57}$.

It is curious that the writer outlines Mr. Geronimo's fortune similar to his greatgreatgreatmother's fortune and in the same way as jinnia Dunia fell in love with philosopher Ibn Rushd, Geronimo encountered Alexandra Bliss Farina who got to know incoherence and absurdity of the world, began her long inquiry into pessimism, was sure of "the absurdity of human life and the incompatibility of happiness and freedom"58 and revealed an exceptional gift for the acquisition of languages, she knew eighteen languages. She has quite unusual view on the civilization meaning as considers that "after years of mayhem can a measure of stable beauty be achieved" country place to heel, ... one must kill and kill and kill, one must destroy and destroy" ${ }^{\prime 60}$, but she summarizes her phrase on the global level appealing to the whole world. Having the pseudonym El Criticon, Alexandra published her essay "The Worst of All Possible Worlds" grounding the theory "that the rift between the human race and the planet was approaching a tipping point, an ecological crisis that was metamorphosing into an existential one"61. At first, her colleagues laughed at her without any suspicion of changing their opinion soon and considering her to be a prophetess.

56 Rushdie, Salman (2015) Two Years Eight Months and Twenty-Eight Nights. New York: Random House.

57 Rushdie, Salman (2015) Two Years Eight Months and Twenty-Eight Nights. New York: Random House.

58 Rushdie, Salman (2015) Two Years Eight Months and Twenty-Eight Nights. New York: Random House.

59 Rushdie, Salman (2015) Two Years Eight Months and Twenty-Eight Nights. New York: Random House.

60 Rushdie, Salman (2015) Two Years Eight Months and Twenty-Eight Nights. New York: Random House.

61 Rushdie, Salman (2015) Two Years Eight Months and Twenty-Eight Nights. New York: Random House. 
The isolation of the Lady Philosopher from the society is deeper because of her estate La Incoerenza location on the banks of the Hudson, "which at the end of its journey is a "drowned river," its fresh water pushed beneath the incoming salt tides of the sea" ... "On the banks of the drowned river La Incoerenza likewise resisted order" ${ }^{\text {"62 }}$. The author skillfully combines the nature's, real estate's and personality's peculiar protest to follow the widespread principles to show how difficult it is to live in a human world having another nature in comparison with the majority.

The estate manager Oliver Oldcastle causes the reader's interest as well as he is a rather contradictory person "loving the Bible and loathing the Church" ${ }^{\text {"63 }}$. But characterizing him the author uses more stylistic devices beside of antithethis, for example, the following comparison: "Oldcastle ushered Mr. Geronimo into the grounds, looking like God showing Adam into Eden, and charged him with the task of bringing horticultural coherence to the place" ${ }^{94}$. Comparison is followed by a humorous remark about "horticultural coherence" which sounds in accordance with the philosophic context, but does not seem relevant to the gardening.

Here is one more bright example of Giacomo Donizetti, who had conquered many women in many places without loving them, after whispering of some jinns women no longer fell in love with him instead he began to fall in love with all women he saw, so he "had become a beast in the thrall of the monster Love" $"$. Metaphorical depiction of love proves that any extreme emotional expression can do a lot of harm and even destroy a person.

\section{CONCLUSIONS}

Thus, the author reveals a lot of drawbacks and sins of the humankind and while considering people's balancing between the good

62 Rushdie, Salman (2015) Two Years Eight Months and Twenty-Eight Nights. New York: Random House.

63 Rushdie, Salman (2015) Two Years Eight Months and Twenty-Eight Nights. New York: Random House.

64 Rushdie, Salman (2015) Two Years Eight Months and Twenty-Eight Nights. New York: Random House.

65 Rushdie, Salman (2015) Two Years Eight Months and Twenty-Eight Nights. New York: Random House. 
and the bad makes the conclusion on the fact that "the human race falls more naturally towards the dark" $" 66$.

In the novel Salman Rushdie embodies both a procurator and a pleader of the humankind - he tells about the global problems of the jinns' world having copied them from the people's world: "I see its shallowness: its obsession with shiny baubles, its amorality, its widespread contempt for human beings, which I must call by its true name, racism" ${ }^{\prime 67}$. Nevertheless, Rushdie is an optimist and in the end of the novel he speaks of "a peaceful, civilized world, of hard work and respect for the land", of "a world ruled by reason, tolerance, magnanimity, knowledge, and restraint" and of "the victory of our better natures over the darkness within" ${ }^{\text {68 }}$.

\section{SUMMARY}

This article interprets Salman Rushdie's novel "Two Years, Eight Months and Twenty-Eight Nights" and the global issues of human realm depicted in it. Magic realist novel features are studied on the level of meaning and form. Such traits of author's individual style as the novel's multilayer structure, intertextuality, the interaction of human (real) and jinns (fiction) worlds, real historical events and persons described, condemnation of the universal human drawbacks and sins, philosophic worldview, global issues of human existence are specified. The characters of the novel are analysed and linked to the typical representatives of the human realm. Some stylistic peculiarities of the text are emphasized and interpreted. The article addresses the author's attitude to the characters and various processes and phenomena occurring in people's society.

\section{REFERENCES}

1. Chemiakin, Ye. Yu. (2011) Obraz multiculturnogo cheloveka v postcolonialnom diskurse [The character of a multicultural man in the postcolonial discourse]. History Annual. P. 25-34.

2. Hegerfeldt, Anne (2002) Contentious Contributions: Magic Realism Goes British. Janus Head: Journal of Interdisciplinary Studies in

66 Rushdie, Salman (2015) Two Years Eight Months and Twenty-Eight Nights. New York: Random House.

67 Rushdie, Salman (2015) Two Years Eight Months and Twenty-Eight Nights. New York: Random House.

68 Rushdie, Salman (2015) Two Years Eight Months and Twenty-Eight Nights. New York: Random House. 
Literature, Continental Philosophy, Phenomenological Psychology, and the Arts,2002, 5 (2), pp. 62-86.

3. Kakutani, Michiko (2018) Critic's Notebook; Telling Truth Through Fantasy: Rushdie's Magic Realism. New York Times (electronic journal), 24 Feb. Retrieved from: www.nytimes.com (accessed 22 Dec. 2019).

4. Konovalenko, T.V. (2017) Typology of Characters in Magical Realism and Chimeric Prose. Literary Imagination.Issue 3 (2), (November), Volume 19, pp. 744-751.

5. Mendes, Ana Cristina, Wesley, Charlie (2017)_New Directions in Rushdie Studies. The Journal of Commonwealth Literature,September, 52(3), pp. 417-421.

6. Rushdie, Salman (2015) Two Years Eight Months and TwentyEight Nights. New York: Random House. (In English)

7. USA Government (2017) Bearing Arms.Second Amendment. Constitution annotated. 03 Oct. Retrieved from: https:// www.congress.gov/content/conan/pdf/GPO-CONAN-2017-10-3.pdf (accessed 04 Jan. 2020).

8. Yusefovich, Galyna (2016) Yest li zhizn posle non-fiction? Da! S romanami Salmana Rushdie i Davida Mitchella [Is there a life after Non-fiction? Yes! With novels by Salman Rushdie and David Mitchell]. Meduza [Jellyfish] (electronic journal). 10 Dec. Retrieved from: https://meduza.io/feature/2016/12/10/est-li-zhizn-posle-non-fiction (accessed 24 Dec. 2019).

\section{Information about the author:}

Tetiana Konovalenko,

$\mathrm{PhD}$, Associate Professor, Dean of Philological Faculty, Bohdan Khmelnytsky Melitopol State Pedagogical University 20, Hetmanska str., Melitopol, Zaporizhia region, 72312, Ukraine ORCID ID: http://orcid.org/0000-0003-4867-324X 


\section{ADDRESSING POLYPHONICITY OF DRAMATIC DISCOURSE}

\section{Valeriia Koroliova}

\section{INTRODUCTION}

The process of artistic communication predetermined by social, communicative and normative factors directs contemporary researchers to the analysis of a literary text in a discursive aspect which reorients linguists to study the pragmatic factor in the text as a manifestation of the communicative intention of an addressee and recipient.

A specific kind of artistic discourse, which is in turn a modification of Ukrainian national discourse, is defined by linguists as dramatic discourse. However, in our opinion, dramatic discourse having only its characteristic features deserves to be singled out and analyzed as an independent discourse which by categorical features is close to dialogical and theatrical (stage) discourses. Generalized modern interpretation of discourse implies enrichment of a text at the discursive level with characteristics due to extralinguistic factors that enhance its pragmatic openness and transform procedurality from an immanent feature into a differential feature of discourse.

Dramatic discourse can be considered a mixed type of communication. On the one hand, it is personality-oriented because it functions in everyday communication, and on the other hand, it is statusoriented because it has an institutional character due to its connection with stage (theatrical) discourse. In addition, modern scholars point to the importance of status role of characters emphasizing the dependence of semantics of a play on social status to which they (characters) are empowered by a playwright. All this determines the specificity of dramatic discourse addressing and the actualization of "double addressing" concept.

The ambiguity of communicative status and the complex system of dramaturgic text addressing lead to different definitions of "double addressing" concept. Researchers of postmodernism trying to counteract the confrontation of high and mass cultures declare double addressing of any literary text as the principle of postmodernist writing aimed at both an average reader and an intellectual. Some researchers (I. Ilyin, L. Strelets) perceive double addressing as an increase in the communicative load of internal communication system due to a lack of explicit dialogue between 
an author and a reader, which makes both characters and readers become recipients of conversational turns. In this case not only are conversational turns marked with relevant remarks, but also any dialogues and monologues of characters are perceived as addressed to readers. While agreeing that the fictitious communication of characters is subordinate to author's main dialogue with a reader, we note that a more accurate interpretation of double addressing, in our view, is its interpretation within the framework of external communication, expressed in paratext elements of a play, adressees of which are aviewer and a director. It should be noted that viewers or readers do not act as direct addressees, but rather as an observer who watches the events unfolding in a play, whether on stage or in dramaturgic text

Dramatic discourse caused by specifics of stage communication is characterized by double addressing which distinguishes director and reader as direct addressees of paratext elements of a play, including remarks. In our opinion, it is interesting to analyze dramaturgic addressing on the material of contemporary Ukrainian dramaturgy which is characterized by a number of specific features, namely: lack of clear local determination of dramaturgic works which causes a decrease in author's communication party at the beginning of a play; inclusion of extra-literary elements to a dramaturgic text, immorality, appearance of marginal characters all increase the dialogicality of contemporary dramatic discourse and affect the paratext component of plays; genre experiment that characterizes modern dramaturgic process allowing a playwright, despite canonical limits of artistic possibilities of a drama, to apply structural extension and functional complication of play's remark layer giving it a narrative feature.

Thus, separation from classical dramaturgic design, genre experiments and implementation of creativity in the text of a play determine the specificity of communicative system of contemporary dramatic discourse. The consequence is destruction of the boundaries between external and internal communication within a text of a modern Ukrainian play.

\section{Addressing as discursive category}

Discursive categories characterizing speech not only as a means of transmission but also as the formation of thought differ from textual categories in their procedural nature, adherence to the criteria of selection of non-linguistic context, the situation of speech creation. Considering the interpretation of modern linguists discourse as a consideration of all the 
spectra of speech functioning in its situationally-communicative, pragmatically-social and culture-historical aspects, we perceive I. Shevchenko's concept as an appropriate one. According to it categories are divided into discursive, separated into cognitive (informative and cohesive) and communicative (intentional, addictive, situational) and meta-discursive, expressed by means of designing discourse as a process - its communicative strategies and tactics, genre-stylistic peculiarities discursive roles ${ }^{1}$.

Recent linguistic studies of dramatic discourse do not pay much attention to implementation of textual categories in plays. Analyzing the text-forming potential of communicative strategies, O. Krynytska presents anthropocentricity, informativeness, intentionality, modality, membership, dynamism, cohesion, coherence, integrity as text categories of a dramaturgic work ${ }^{2}$.

N. Safonova within the limits of a dramaturgic work distinguishes such specific textual and discursive categories as continuum, dialogism, expressiveness, emotionality, anthropocentricity. However, the categories of expressiveness and emotionality that the author interprets as "a means of creating an artistic image, revealing the inner world of actors, a way of expressing the modal load of the whole text" are characteristic of any work of $\operatorname{art}^{3}$. Just like anthropocentricity as a tripartite explication of subjective-modal coloring of a text (with levels of author, characters, reader) is peculiar to other works of art.

Given the available linguistic studies all discursive categories can be divided into universal (invariant), which are characteristic of the vast majority of discourses, and specific (individual), characteristic only of a particular discursive variety. In particular, modern linguists cite such discursive categories as individual: within the limits of Internet discourse - virtuality, accessibility, multimedia, hypertextuality; within the limits of political discourse - agonizing, aggressive, ideological; within the educational-pedagogical discourse - paraphrasing, polysemioticity, integrativeness.

${ }^{1}$ Shevchenko I. S. Discourse and its categories. Bulletin of Kharkiv National University. 2011. No. 973. P. 8.

${ }^{2}$ Krynytska O. I. Implementation of communicative strategies in artistic text. Ivano-Frankivsk, 2009. P. 5.

3 Safonova N. M. Subjective modality in dialogue and polylogue of contemporary Ukrainian drama. Donetsk, 2006. P. 11. 
An important category is that of an addressee expressed in the program's built-in textual addressing to a hypothetical reader which should help optimize the understanding and integration of a text by a real recipient. According to A. Vorobyova the category of addressing is interpreted as a text feature through which author's idea of the potential addressee and the peculiarities of his/her interpretative activity are verbalized ${ }^{4}$. The structure of discourse conditioned by presence of an addressee and an addresser explains the importance of the category of addressing that comes to the fore in the process of perception of a work. The peculiarity of dramatic discourse is the sign of double textual addressing because, thanks to remarks, plays always have two addressees: one is the playwriter and the other is the viewer. We should note that a viewer or reader does not act as a direct addressee, but as an observer who watches the events unfolding in a play, whether on stage or in dramaturgic text.

A play's director is an addressee who is eliminated from the direct text in play's paratext zone and is obliged to facilitate the implementation of play's dramaturgic design. In this case areader who turned to any contemporary play is defined in the structure of dramatic discourse as an addressee, who receives information aimed at both a viewer and a director.

Addressing significantly affects the division of dramaturgic space. The external nature of text division expressed by the presence of structural part is caused by the peculiarity of human world perception, so a speaker tries to achieve the success of text communication through adequate division of the proposed text. Among the means of discretion are: utterance, paragraph, chapter, section, etc. - at the formal level; sentences, transphrasal unities, microtexts, periods - at the semantic level.

Double addressing determines the peculiarity of formal structuring of contemporary plays. Dramaturgic literature text, as opposed to epic and lyrics, focuses not only on the verbal reproduction of a picture of reality recorded in writing. The basis of the play is another artistic and aesthetic principle of the image according to which the text of a play is designed for reproduction on stage by real people (actors), which motivates the specifics of its language organization. The stratification of dramaturgic fabric of a work into replicas of characters and author's remarks

\footnotetext{
${ }^{4}$ Vorobyova O. P. Text categories and addressee factor. Kyiv: Higher School,
} 1993. P. 117. 
determine the specificity of the category of discretion in dramatic discourse.

The importance of extra-lingual factor in a drama justifies the interruption of characters' conversational turns by author's narratives, which constitute the paralinguistic accompaniment of characters' speech. It should be noted that replicas and remarks of a dramaturgic text are distinguished not only graphically (presentation of remartks in brackets, font reduction, use of italics), but also stylistically. In this case we can talk about the appointment of the former (replicas) to characters, and the latter (remarks) - to a director, emphasizing the addressing of the entire text to a potential reader.

This situation transforms the dialogicality of dramatic discourse which is due, according to A. Hubersfeld, to the fact that conversational turns are always generated by a communicative situation, always addressed to someone ${ }^{5}$. Double addressing determines both the internal and external dialogical nature of drama. Internal dialogism is peculiar to any artistic discourse, since in its structuring the elements "author - text reader" are always involved. Ocassionally linguists even identify the concepts of "dialogue" and "discourse" defining discourse as a communicative act that involves two roles - speaker and addressee. In this case, in dramatic discourse the role of a speaker is performed by an author, and the role of an addressee by a reader. Perceiving dialogue as a two-way communicative process in which each participant of a dialogue is a subject and simultaneously an object of speech influence, a reader becomes a passive participant of dramatic discourse, which, however, does not diminish his/her importance as a communicator.

External dialogism is the dominant feature of dramatic discourse. The implementation area of external dialogism is communication of characters of contemporary plays. External dialogism is also characteristic of everyday discourse, whose stylization, in fact, is dramaturgic dialogue. However, a dramaturgic work is characterized by speech "engagement" in which reader is already involved in the structure of a text through author, who takes into account tastes of potential recipient during the creative process, which is why the "engagement" of a dramaturgic work causes the "concentration" of dialogism in personal communication compared to everyday communication dialogues. External dialog is motivated by

${ }^{5}$ Yubersfeld A. Instead of preface. Pavi P. Dictionary of theater. Moscow: Progress, 1991. P. 7. 
support of communicative activity of a character by author's intention. In this case, even the monologue speech of a characher, who is on stage, contains elements of dialogue. A monologue from P. Arye's play "Colors" provides an example of it:

A woman in white. They took away the father. I have never seen him again. At school-byname -children of the enemy of the people. What kind of people? (Sits on the floor or cube). My mother was taken away, beaten and raped every night. Wife of the enemy of the people. She got pregnant without a father. The boy was born dead. I don't know if I could hate him? No! Cross out the last one! ... I would love him more than myself... Perhaps, in many respects, I am also to blame... I used to sew quite well, but I did not finish my life very well. Everything passed by just like in tango. (Upward commanding tone). Maitre! Size 2/4, the pace is moderate!

The analyzed separate monologue from P. Arye's play "Colors" spanning several pages of text proves the existence of explicit markers of dialogicalness in monologue speech (appeals, interrogative and imperative constructions). Internal dialogue of a play taking into account addressee factor determines the presence of expressions of external dialogue in character's speech.

In this case we consider appropriate to use the term "polyphonic" to refer to a category of dramatic discourse that reflects the specificity of addressing in contemporary plays. Any character's replica having a dual direction is defined by polyphonicity: aiming at both a partner in personal communication and a potential reader.

In the same way, author's remarks are intended for both writer and reader since drama as a kind of literature requires paratextual remarks for director. On the other hand, the choice of drama's author for implementation of a creative plan is motivated "not so much and not only "to play" it, but because he/she needs exactly this and no other form of verbal-artistic image" . It should be noted that lack of narrative in a dramaturgic text and the imposition of a double address on a reader, who plays the roles of both a director and a viewer, enhances the importance of imgaination in the recipient of a contemporary play. In this case a reader needs to imagine a dramaturgic effect, reconstruct the missing elements in a text, which leads to a successful perception of a dramaturgic text and

${ }^{6}$ Vinokur T. G. On the language of contemporary dramaturgy. Language Processes of Contemporary Russian Fiction. Moscow: Science, 1977. P. 137. 
author's intention implementation. Lack of detailed descriptions of interior, portrayal of characters, depiction of internal status of characters in the text of a play enhances the importance of receptiveness of reader's perception, usage of his/her intuition and creativity.

Thus, the category of addressing significantly influences both formal division of a dramaturgic text and overall sense of polyphonicity, even in monologically solitary characters' replicas. This multi-level structuring of addressees leads to a stylistic stratification of the text of a play: a text aimed at a director should be simplified, emotionless while characters' parties should be filled with emotional and evaluative connotation, and they become the epitome of authorial talent. However, modern drama captures blurring of the boundaries between the two text registers which eliminates stylistic marking of addressing.

\section{Paratext as means of explisit addressing}

A dramaturgic text illustrates the pluralistic addressing of paratextual components of a play most clearly. In scientific community the term of "paratext" as a designation of non-textual elements, which, taking the limiting place, significantly affect the complex nature of the relationship between the text, author and reader, was introduced by G. Genette ${ }^{7}$. The parts of a play in which an author can directly address the production are a list of characters and remarks.

The list of characters is an important means of direct expression of an author's intentions which modern playwrights use to inform a director, predict and interest a reader. The list of characters is a manifestation of author's communicative activity, explicitly directed at a reader as an object of playwright's speech influence which determines the level of deployment of the characteristics of each character and the actual tone of that characteristic.

According to the degree of author's description detalization of characters and pragmatic potential we consider it appropriate to offer a distinction between minimized, concise and detailed lists of dramaturgic characters. At times the lists of characters are minimized, devoid of not only author's character traits, but even character nominations. For example, in E. Kononenko's play "Call man" we have the following description:

${ }^{7}$ Genette G. Paratexts: thresholds of Interpretation. Cambridge: Cambridge UP, 1997. P. 2. 


\section{List of characters:}

$\mathrm{He}$

She

People in episodes and on the phone.

To those with a minimized level of characteris description we also include lists of characters that enumerate only neutral character names that are devoid of pragmatic load in semantics. For instance, the following list is presented by T. Ivashchenko in the comedy "Ordering Love":

List of characters:

Vira Mykolayivna

Kyrylo

Nadiia.

Priority in the studied dramaturgic works is concise authorial descriptions of characters in the list in which a playwright selects only one trait, favoring family, age and social characteristics, e.g.:

List of characters.

Oksana Pavlivna Pokotylo, 43 years old

Olha Pavlivna Karpenko, her sister, years old

Tayisiia Nazarivna Kostenko, their mother, years old

Nadiyka and Sonia, Olha's daughters, 6 and 4 years old (H. Lehka "Pornography").

Another instance is the list of N. Doliak's play "Gastarbeiter seasons" (age, family and social characteristics, description of appearance, psychological evaluation) which has detailed author's characteristics:

List of characters:

Sasha Alex - a fragile woman, 45 years old. Tries to look much younger. She succeeds. Fun and energetic person. Former dancer. Woman of fashion.

Katia-Katarina - at most twenty-five years old. Tall, looks like a model, though she dresses very clumsily, always with a sad look. Former sportswoman.

Olena-Helena - an elegant delicate lady of middle age. She is fluent in German - in the past a teacher. Widow.

Kolia-Helen's son. Candidate of Engineering, looks like a mouse, an elderly slender man.

Tamara - his mistress. Too beautiful as for such a man, a woman who resembles a Japanese statuette. 
Detailed lists of characters make it possible for a playwright to contact a director directly, to draw attention to those character traits that are important for revealing author's position and concept of a play.

In lists of characters at times we have direct addressing only to a director, for example:

$C A T-$ man in black

PUSSY CAT - woman in white

$B O D Y$ - speechless and overall "less" (actor is not required) (N. Nezhdana "Loneliness suicide").

Another parathex element relevant to addressing is a remark which should be interpreted as a conversational turn of author's speech party in author-reader dialogue. In this case all narratives perform either a conversational turn function or a narrative function which has recently become widespread in contemporary dramaturgic texts. The typology of remarks is still not unified and it is ambiguous and vague in the lexicographic literature. We consider it appropriate to classify remarks by their structure and communicative functions. Let us analyze the proposed typology of remarks on specific examples.

1. A replicated representative. Representational function is traditional for a remark ${ }^{8}$ because this feature allows recipient to perceive extracurricular reality without involving the event sphere. Representative remarks state physical, mental state of participants in dramatic discourse.

A shortened replicative representative is expressed by a sentence with a partially filled out scheme in which character's name is often a subject and the predicative function can be performed by a conversational turn, e.g.: Valerii (turns to Olha). For all saints and sinners, keep quiet! (A. Bahrian "Treat me with nuts"); Tania (looking at her watch). Twenty minutes left (O. Viter "Station").

A representative remark expressed by an ellipse for highest possible syntactic compression is a component of a complete sentence that is consistent with the components of a conversational turn and character's name, e.g.: Yan (to Valeriia). You also need to leave. It will be better (V. Tarasov "Love Hunting Season"); Dubelt (to a Servant). Thank you, my friend (S. Rosovetskyy "Shevchenko under court").

A non-shortened replicated representative has the form of a single complete two-sentence sentence in which a character may not even have a

8 Baklanova A. G. Linguostylistic characteristics of drama as text type. Moscow, 1983. P. 3. 
communicative initiative, but his/her actions stated in a conversational turn are a direct reaction to the previous replica. Example:

Clavdia Semenivna. Go.

Grandma Hanna goes out (V. Kanivets "I want to be the president").

2. Replicated descriptor. Remarks with a descriptive function are not intended to be a statement but rather a description of a phenomenon, event, object. Such footnotes at most indicate the interpenetration of author's communicative party to communicative activity of characters. For example: Woman (through her teeth). You can say just Vira... Heorhiivna (N. Nezhdana "The one who opens the door"); Olena (playfully). Hopefully it's not the only nail the house holds? (O. Pohrebinska "I know five boys' names ...").

3. Narrative. It represents providing dramatic action with a narrative character through introduction to a play of fiction elements that indicates author's intention of monologizing. A narrative remark contains as much information as possible about the stage production. A noncommon narrative is expressed by one or two sentences that have no more than two predicative centers. Example:

Andrii. Why? I am drinking, I've just drunk three cups today ...

Andrii sits at a table. Halyna is making tea (N. Nezhdana "When the Rain Returns").

Syntactic construction with more than two predicative centers is characterized as a widespread narrative remark which is interpreted as author's communicative party, which can contain not only descriptions of events but also reflection, evaluation and expression of a playwright. For instance:

They drink champagne ... Marital life begins. Franko sits down to work. Olga cleans the house (T. Ivashchenko "The secret of being").

Further complication of widespread narrative remark by author's intentions leads to fictionalization of remarks. Example:

Change of light. Barely audible, gradually approaching, "Eternal memory!" Sounds. When the tune gets tight behind the stag it enters the stage and the hall along with the funeral procession. They carry a small white coffin. Behind the coffin there is Lira with a dark veiled head, Semirid and all the villagers. Father Antoni and Lira stop on stage and watch the procession. And "Eternal Memory!" weeps with unspeakable pain, combining notes of sorrow and... optimism. This two-word requiem has become one of the most ingenious works of Christianity ... The unspeakable longing of man for man, the complaint of humanity to the 
cruelty of death which does not have any mercy ... (M. Nayenko "To Heaven - on foot").

Such narratives determine further development of a play, structure dramatic discourse in general. Fictionalized drawings are aptly treated as epic miniatures that, apart from traditional features, are marked by meaningful elegance and compositional design ${ }^{9}$, for example:

"Benign Thursday" dance show. (It is such a rare day in life. People can't help enjoying themselves. A boy is cheering happily, a businessman goes out of town to look at a house with a garden. Old people sit looking away from a distance, sadly recalling that at their young age all the days were like that. Horses were lying on a green meadow. The chickens were cackling, waving their wings in the sun. A happy day when one manages everything). Joseph-Maria's stall. Master and Mak (S. Lazo "This is Life!").

Fictionalized narratives at most demonstrate double addressing of dramaturgic discourse since such intrusions of author's speech activity into the textual array of a play contain an explicit attempt to influence a director connected with the perception of hidden meanings of a play. Example:

Intrigue continues to evolve into the best examples of a classic detective. After a while the armored door opens. First and Second roll out a large trunk on wheels. Looking around they run to the front door slightly opening it (J. Vereshchak "Stefko sold to mormons").

It is easy to notice the difference between these fictionalized remarks and the traditional ones which fulfill their primary function of ascertainment and are aimed at a double addressee.

Occasionally fictionalized notes from the implicitly expressed form of author's speech party become a real explicit author's speech activity. For example, in V. Rybachuk's play "Solo for Two" the author using a conversational turn presents his own thoughts-appeal to a director about the fate of his dramatic work, warning the object of communication about possible consequences of stage embodiment of the play:

This is not the final version of action development... The action may develop in a different way: as each of us imagines it, or may have already "played" in our lives. That play is not a performance. I am not sure that a director who will (hopefully) ever turn this play into a performance will not

9 Zaitseva I. P. Poetics of contemporary dramaturgic discourse. Lugansk: Alma Mater, 2007. 332 p. 
be homosexual, zoophile or, for example, a rodent, and the play text will not only perceive the play through the lens of his physiological (or party) preferences. so when nymphomaniacs in knightly armor will run after a naked man on stage - do not attribute this to me, and when an actor says, "This is all a lie" and the text does not contain it, it will not be the opinion of an actor, mine or yours. Our thoughts do not always coincide.

In this example author's speech activity is quite real and reader's party remains virtual. Author is not acting as a mediator between reader and event trying to program recipient's emotional response, but rather as the subject of communication in the dialogue with reader. Unlike double textual addressing, which is typical of play texts (there are always two addressees in play texts: director and viewer), the shown remark is explicitly directed at reader as the object of author's speech influence.

Conversational turns with explicit markers of appeal to a viewer have a special communicative load. Such conversational turns lead to destruction of the so-called "fourth wall" which delimits the fictional world of drama from audience and is labeled with word forms like to the viewer, to the audience. Example:

1. Den (to the public). And when angels lose their feathers, does it hurt or not? Does anyone know? No? (N. Nezhdana "Deal with angel").

2. (Green and Brown lower their heads ... In the frenzy they smear makeup on each other's face and body. They turn to the audience).

Green and Brown. Please!

Voice. What do you think about this? (A. Vyshnevskyy "The Difference").

3. A sadist. (To the hall). Hush... Keep quiet, children, quiet because you will be in trouble (J. Vereshchak "Uniformist").

It should be noted that contemporary authors introduce such remarks to the structure of a dramaturgic text to engage reader in dramaturgic discourse as an accomplice to the play's co-author. At times further character's replicas may even mimic character's direct dialogue with viewer with the latter's alleged replicas. For instance:

1. Similarity. Well, how do you find the fairy tale? If it weren't for me, then it wouldn't exist. Do you like it or not? I can't hear it, louder! Did you like it? Well, then come again and bring to our underwater kingdom all friends who have not seen it. Be therefore rich as the Earth, and healthy as the water! (V. Serdiuk "Adventure Day, or June 32").

2. Overseas-looking sir (addressing the hall). Don't you know where the authorities are located here? I have to keep my grandfather's will and give this treasure to the local state. No? Don't know? Hey, are 
you walking? And what will I do with all this? Please help. Well, someone? Maybe you, a young man? Either not. Horror, what a proud nation, and nobody wants gold here already... (V. Serdiuk "Adventure Day, or June 32").

Such expressions of explicit addressing are placed by an author in strong positions in a dramatic text, namely, at the beginning or end of a play. Appeal to a viewer / reader of a play may not be on behalf of a character, but be rather directly authorial and contained in optional drama components, such as epilogue or prologue. For example, S. Brama in the play "Pig liver" presents the following epilogue:

There will be no applause today, because together with you we honor the moment of silence of all victims of unjustified cruelty.

N. Bondarenko in the play "Sky colour chrysanthemum" addressing reader in the prologue explains the structural specificity of the drama, which encourages addressee to the perception of the work:

The play is based on the "Mobius tape" in dialogue with the Japanese writer Rennyo. The combination of Japanese and Ukrainian cultures gave an unexpected effect, which can be felt reading the play.

Place of direct appeals to a viewer / reader in strong positions of the text provides highlighting the most important meanings of a text, focusing attention on the most important, enhancing emotionality and aesthetic effect, as well as demonstrates the importance of an addressee in dramatic communication, his/her permanent influence on a playwright creating a play.

\section{Settings as specifically addressed dramaturgic text}

Separating the main body of a dramaturgic text which presents characters' internal communication as the stylization of live oral speech and the so-called "texts in the text" which make up paratext elements of a play (title, subtitle, list of characters, remarks, etc.), the researchers highlight introductory remarks as a prime example of a playwright's direct appeal to a director. Such introductory (mise-en-scene, introductory) remarks are called settings by linguists, they are means of reproducing the "naturalness" of a situation, the ease in actor's moving on stage, the conformity of all elements of the stage space decor with the appearance of actors ${ }^{10}$. It is the setting which is the most striking example

10 Kubriakova H. S. In search of language essense: Cognitive Studies. Moscow: Badge, 2012. 208 p. 
of dramaturgic text double addressing. Communicative function of these remarks is quite significant, as they affect the success of author's embodiment, compensating for the lack of information on the conditions of internal communication of characters, due to the specificity of dramatic discourse, devoid of narrative. Such settings are traditionally distinguished purely linguistically, verbalizing in laconic sentences with verbal expressions of meaningful content the communicative task of which is to announce presence in surrounding reality as a whole or in its individual fragments of corresponding objects with their characteristic features. Example:

1. Hospital ward. Late Night. There is a large window on the right. Left door. There are two wheelchairs on the backstage. Lysy and Borodan are sleeping there (V. Serdiuk "Merciful sister").

2. Bohdan's apartment. Living room. Home environment. Table with chairs.

Poliusia pulls Max's hand from the doorstep. Dressed as modern "progressive" youth (A. Bahriana "Angels have something from evil").

In the studied plays addressing of remarks to a director proves the usage of theatrical terminology in the structure of a dramatic text, for example:

1. All objects and decorations are present on stage at the same time. Shared space. Everything is conditional. Stage. Even actors. After all, they are also here on stage, but they are not visible. Spectator will see them when needed. They will all remain on stage until the end of the play, becoming actors for a while and spectators of their colleagues' mise-enscenery on stage for a while... They will come to life and become active when it is their turn and while they are spectators as well the only difference is that they are sitting not in the darkness of orchestra stalls, but in the twilight of the stage (O. Zhovna "Experiment").

2. It is half-dark. The curtain is open. Room. Decorations are conditional - with replacement of several detail the room is transformed into any other room specified in the play. On the left side of the front stage there is a chair and a coffee table - this is Darina's place, illuminated by a spotlight. There is a light, quiet, slightly sad melody (leitmotif of the play) (N. Uvarova "The Undying Heart").

Settings reproduce reality both in reader's and director's imagination with subsequent implementation for spectator. It is for director that playwright's directives are introduced, the most important of which are visual and sound aspects. The visual aspect is the layout of 
stage, decorations, lighting, details, costumes for actors. Here are excerpts from several settings that illustrate the visual guidance:

1. Large living room, tastefully decorated in a modern studio. On the walls there are pictures by Yakov Hnizdovskyy "Cat's Dreaming" and "Pink Beech" (O. Mykolaychuk "Flower for three months").

2. Evening. The front door bangs. Jack in a short jacket and jean enters the room. He puts a bottle on the table, opens it, pours it into a glass and drinks (S. Shchuchenko "Noble Don").

3. The stage is divided into three parts. Almost the whole wall is occupied by a painting. In the hall there is a table for a chairman of the meeting, chairs for participants. At the end of the hall there is a door to the compartment where the costumes were stored, and now there are tables with bottles and dishes for the feast (A. Naumov "Department for the decent").

Sound implementation aims to outline the sounds of nature, city, voices behind the stage, special effects. For instance:

1. Wind whistling. The passage from Dmytro Dontsov's article about O. Teliha "Poetry of Fire Borders" is read in a male voice (A. Bahriana "Sadness and Passion").

2. Night. Some strange sounds are heard. They are joined by voices of trembits (T. Ivashchenko "Secret of being").

3. Light goes off, hissing of carriage doors can be heard, the clatter of carriage wheels is distant and dog's barking is very close (V. Danilenko "Money for Ionesco").

Addressing a director is also indicated by the presence in remarks of author's comments which cause variations during the production of a play which is marked in remarks by corresponding lexical items. In this case author allows future director to select the details that he/she thinks will be the most suitable for the reproduction of the scene and the course of a drama. Example:

1. Park of a clinic for mentally ill. A Cropppar-like man in pajamas sits in a wheelchair and mutters something gibberish (perhaps Sanskrit). Nietzsche walks nearby - in a suit, with a stick - but it is not clear who he is (T. Kytsenko "The three Nietzsches").

2. Den is at home, collects a bag - there is a wig, makeup, a hare mask in it. Castle opening is heard. Den abruptly hides everything in a bag, a bag in a box, and the latter hides, for example, under a bed and hangs something (it may vary) (N. Nezhdana "Deal with angel").

3. On the stage there is a movable table with crushing traces of multi-day drinking (appropriate minimum of props - for theater 
consideration). Almost under the table lies a man. This is Miryk. He wakes up. Sits down (O. Slipets "Chronicles of the first year").

At times such remarks are used by author at the same time for selfpresentation and creation of a certain emotional mood, for example:

A fire is made. Certainly there may be problems with the fire department of the theater - but still some kind of fire would be desirable (N. Nezhdana "Loneliness suicide").

It should be noted that structurally settings of contemporary Ukrainian plays are quite diverse: from a detailed description of interior with clear authorial comments to an abstract rendering of the scene without specifying the stage embodiment. In this case we trace the dependence of syntactic structure and stylistic design of remarks on the function of this element of a play, allotted by author. The more specific and transparent setting addressing is to director, the more structurally easier and expressively neutral is the text of setting. Playwright's deviation from the classic for a drama addressing to director causes complication of syntactic organization of setting and actualizes the detection of author's origin in the text of remark. Let us compare two mise-en-scene settings that were given at the beginning of a play:

1. Ivan and Ivanna's apartment. In the middle there is a corridor with an entrance door. On one wall there is a large chandelier, on the opposite one there are clothes hangers. Beneath the wall there is a brush stand. To the left of the corridor there is a toilet, a bathroom and a kitchen. The kitchen includes a refrigerator, stove, numerous cabinets, a table and a seating area. To the right of the corridor there is a room. The room has bookshelves, a wardrobe, a large sofa. There is a desk with an armchair on the couch, a computer on the desk. In the corner by the window there is a TV. In the middle of the room there is a large carpet (A. Shamayeva "Last chance, or how to spend leisure time correctly").

2. Deep darkness of the scene is torn apart by a long, white female cry that suddenly breaks on an incredibly high note. Gradually intersecting light breaks through concentrating on the cramped female body that freezes into the floor, there is another figure hovering above - a shadow of a person or a human-shadow, a medium - a perennial manifestation of instantness - a child... a girl... a woman... a witch without signs of time... person ... A half-dark room. Blurred lines blur space - half-dream ... half-life ... (L. Chupis "Pottery Circle Dancing").

The first excerpt is composed of structurally simple sentences with semantics of a statement that neutralize but accurately depict play's scenery. In the second example there are complex sentences, termination 
of phrases is punctuated by three dots, which conveys considerable emotional tension. In this case there are no specific notes for director about interior and the course of further actions in a play and indeed addressing to director itself is leveled.

\section{CONCLUSIONS}

Given the peculiarity of dramatic discourse perception in a communicative act (reading or stage embodiment) the situation of text perception, its structure we define drama text as the text of polyphonic addressing which is the sole link of communicative process between addressee and addresser. Thus, it can be stated that dramatic text is defined as a structurally heterogeneous text simultaneously represented by two forms of existence, written or staged, represented by both textual and paratextual components.

Dramaturgic text has double addressing expressed in paratext elements of a play, the recipients of which are viewer and producer. In particular, remarks are directed to director, characterized by structural simplification, clarity, presence of theatrical terminology. Leveling of addressing to director causes complication of syntactic organization of remarks, which in some cases demonstrate explicit involvement of reader in theatrical action. An important component of addressing to director is setting, structurally and functionally diverse.

Thus, contemporary Ukrainian dramaturgy captures numerous shifts in textual and paratextual elements regarding their traditional addressing. Replicas are directly addressed to reader in some places, paratext component becomes a stylistically colored expression of author's origin, which reorients $\mathrm{him} / \mathrm{her}$ from the classic form (emotionally, structurally mature, simplified) into a paradigmatically meaningful component of a play.

\section{SUMMARY}

Modern Ukrainian dramatic discourse is characterized by experiments with form and content which explains modifications in traditional addressing of a dramatic text. Traditionally paratext (footage, list of characters, etc.) addressed to the stage director has a simplified form and neutral styling; emotionally colored are the remarks addressed to actors that make up play's internal communication. However, modern play demonstrates erasure of these canons, transition to addressing director in the area of replicas, enhancing emotional part of a conversational turn. We also record changes in introductory remarks, socalled setings: appearance of stylistic changes in them, violation of clear 
instructions for director, expression of author's emotions and experiences. All this transforms, mixes pragmatically important parts of a play, modifying the addressing of dramatic discourse, making it polyphonic.

\section{REFERENCES}

1. Baklanova A. G. (1983) Lingvostilisticheskaya kharakteristika dramy kak tipa teksta [Linguostylistic characteristics of drama as text type]. Moskva (in Russian).

2. Vinokur T. G. (1977) O yazyke sovremennoy dramaturgii [On modern dramaturgy language]. Yazykovye protsessy sovremennoy russkoy khudozhestvennoy literatury. Moskva: Nauka, pp. 130-197 (in Russian).

3. Vorobyova O. P. (1993) Tekstovye kategorii i faktor adresata [Text categories and addressee factor]. Kiev: Vishcha shkola (in Russian).

4. Zaitseva I. P. (2007) Poetika sovremennogo dramaturgicheskogo diskursa [Poetics of contemporary dramaturgic discourse]. Lugansk: Al'ma-mater (in Russian).

5. Krynytska O. I. (2009) Realizatsiya komunikatyvnykh stratehiy u khudozhn'omu teksti [Implementation of communicative strategies in artistic text]. Ivano-Frankivs'k (in Ukrainian).

6. Kubriakova H. S. (2012) V poiskakh sushchnosti yazyka [In search of language essense]. Moskva: Znak (in Russian).

7. Safonova N. M. (2006) Subyektyvna modal'nist' u dialozi ta polilozi suchasnoyi ukrayins'koyi dramy [Subjective modality in dialogue and polylogue of contemporary Ukrainian drama]. Donetsk (in Ukrainian).

8. Shevchenko I. S. (2011) Diskurs i ego kategorii [Discourse and its categories]. Visnik Kharkivskogo natsionalnogo universitetu. № 973, pp. 7-10 (in Russian).

9. Yubersfeld A. (1991) Vmesto predisloviya [Instead of preface]. Pavi P. Slovar teatra. Moskva: Progress, pp. 7-9 (in Russian).

10. Genette G. (1997) Paratexts: thresholds of Interpretation. Cambridge: Cambridge UP.

\section{Information about the author:}

Valeria Koroliova,

Doctor of Philology, Assistant Professor, Head of the Department of Ukrainian Language,

Oles Honchar Dnipro National University 72, Haharin Ave., Dnipro, 49010, Ukraine ORCID ID: orcid.org/0000-0002-7482-0517 


\section{FEMININE WORLD OF ANN OAKLEY'S NOVELS}

\section{Alla Marchyshyna}

\section{INTRODUCTION}

What is there in a plot? A fiction text of the so-called "traditional" structure comprises a set of elements that make up its story, i.e. a plot. Since school years, the reading audience knows that there should be such components as introduction, conflict, rising action, climax, falling action, denouement. Their arrangement may be different depending on the text composition but the given list is almost complete and is expected to provide the exciting narrative. The present study isn't aimed at challenging the relevance of constituents of the plot structure. On the contrary, it seeks to prove whether it is enough for a plot as a text skeleton. Here, the assumption is made that a plot may acquire one more characteristic feature: gender colouring.

There may be suggestions that the latter is rather a matter of stylistics than of a plot itself. The deep insight into some texts gives rise to the idea that it does refer to the plot. Text stylistics due to its nature focuses on the imagery in its general and peculiar senses: it transforms concepts into images thus provoking the readers' intellectual and emotional spheres making the process of text contents perception interesting and emphatic. Stylistics is there on the surface.

Plot is another cup of tea. It is deeply inside the author's worldview implemented into the events that constitute the plot. The selection and arrangements of events reflect the author's hierarchy of (literary) values. As far as any literary text is not a precise reflection of the world but is its artistic representation, the very choice of the events the author endows with importance and functioning in a plot determines its gender bias and identification signals. The plots with distinctive gender colouring are characteristic of Ann Oakley's novels.

A plot of a fiction text is not just a kind of storytelling, neither it is a container of events which either the author or the narrator hurry to make public to impress the reader. First, to a complete text, a reader might ask a question, "What has happened?" There is no plot if nothing has happened. And here it is the starting point to identify the gender colouring of the plot. Though some researches prove that "gender differences emerge more commonly in spoken than in typed 
narratives"1, similarly, there exists psychological assumption that importance of events (What has happened? Has anything happened?) is ranked differently by men and women: "men and women are two distinct groups of people who think, communicate, influence, and lead in different ways" . Thus, the sequence of events making up a plot is gender dependent.

Second, there arises a question how the plot events are arranged. Here, the role of an author is crucial as far as it is an agent who translates the scope of information to a narrator and endows this text construct with functions to render the assigned "data" to a reader. In this respect, R. Franzosi's observation proves successful stating that "narrators and narratees constrain how events are narrated. The focus on how involves a focus on plot (rather than story), on rhetorical efficacy, on the strategic mix of pure narrative, description, and evaluation, and on the effective use of language)"3. These verbal means of a plot expansion become semantically and stylistically loaded elements determining text perception and interpretation.

Gender-related events assessment commonly originates from a bipolar spectrum of problematic loadings on the factors both triggering and resulting from the events in question. This way the dimensions of plot lines are specified which are termed gender-role preferences ${ }^{4}$. They are implicit in gender-related social norms and the gender-related characteristics which acquire verbal forms in a fiction text. Hence, nonrelative, absolute statements are hard to maintain in a belles-lettres style which is qualified as highly subjective and biased (see, for example, M. Longo ${ }^{5}$ who considers a literary text as a result of a subjective process) whereas only "science has been traditionally seen as the major, if not the

1 Grysman A. et al. The influence of gender and gender typicality on autobiographical memory across event types and age groups. Memory \& Cognition. 2016. Vol. 44. P. 856.

2 Merchant K. How Men and Women Differ: Gender Differences in Communication Styles, Influence Tactics, and Leadership Styles. Senior Thesis. Claremont McKenna College. CMC Senior Theses. 2012. Paper 513. URL: http://scholarship.claremont.edu/cmc_theses/513. P. 13.

3 Franzosi R. Quantitative Narrative Analysis. Thousand Oaks: SAGE Publications, Inc., 2010. P. 46.

${ }^{4}$ Shapin S. The Science of Subjectivity. Social Studies of Science. 2011. Vol. 42 (2).

5 Longo M. Fiction and Social Reality. Literature and Narrative as Sociological Resources. London and New York: Routledge, 2016. P. 111. 
only, domain where objectivity lives" ${ }^{\text {. }}$. Scholars may even go too far and doubt what fragment of reality is the text focused on and to what extent it relates to reality. Take, for instance, H. M. Davidson's interpretation of M. Proust's theory of text where the similar idea is emphasized ("Proust is here sharing a common understanding of literature, namely the feeling that it contains some form of truth about reality; but it is not clear, what kind of truth this is!"7).

Likewise, it is caused by the long-rooted stereotypes. As N. Ellemers states, "gender stereotypes affect the way people attend to, interpret, and remember information about themselves and others" 8 . The same suggestion was proved by the empirical research ${ }^{9}$ which concluded that narratives depend on gender bias both in the way of factual elaboration and interpretative elaboration.

\section{Method}

To qualify the plot events as female or male dominated, McAdams' life story coding system ${ }^{10}$ may serve the ground for differentiation. Here, the two basic concepts of agency and connectedness constitute the milestones for male or female priority in events selection and description. It continues Bakan's ${ }^{11}$ theory of agency and communion where agency is meant as "personal achievement, power, and the assertion of the individual self $\langle\ldots>$ Themes of communion express desires for love,

6 Longo M. Fiction and Social Reality. Literature and Narrative as Sociological Resources. London and New York: Routledge, 2016. P. 170.

${ }^{7}$ Davidson H. M. The literary representation of reality. Res Cogitans. 2018. Vol. 13 (1). P. 115.

${ }^{8}$ Ellemers N. Gender Stereotypes. Annual Review of Psychology. 2018. Vol. 69. P. 275.

9 Grysman A. et al. The influence of gender and gender typicality on autobiographical memory across event types and age groups. Memory \& Cognition. 2016. Vol. 44. P. 856-868.

${ }^{10}$ Mansfield E. D., McAdams D. P. Generativity and themes of agency and communion in adult autobiography. Personality and Social Psychology Bulletin. 1996. Vol. 22. P. 721-731; McAdams D. P. et al. Continuity and change in the life story: A longitudinal study of autobiographical memories in emerging adulthood. Journal of Personality. 2006. Vol. 74. P. 1371-1400.

11 Bakan D. The duality of human existence. Boston: Beacon Press, 1966. $242 \mathrm{p}$. 
friendship, and community"12. The scholars consider agency as "the expression of autonomy and self-efficacy, a sense of controlling one's life" whereas connectedness "is a sense of relatedness and valuing others" ${ }^{\prime 4}$. Though agency and connectedness have acquired malestereotyped and female-stereotyped features respectively, this study aims neither to verify nor to counterclaim the traditional beliefs. The research seeks to demonstrate how gender related and gender valued events and their interpretation construct the plot of Ann Oakley's novels "The Men's Room", "Matilda's Mistake", and "A Proper Holiday".

\section{1. "The Men's Room"}

The story focuses on adultery, a love affair between the protagonists, a man and a woman. It may seem a typical situation at first sight. Two middle-aged university professors abandon their spouses in search of new passion. Deep in the family and household chores, they are thirsty for adventure and risk, open to changes and challenges. It produces a chain reaction: their refusal to stay in the marriage results in their spouses' desire to take revenge for breaking the wedding vows. Everybody gets rid of family obligations, and the problem is not resolved but deepened.

The lovers get nothing what they expected. They face moral confrontation, combat criminal sanctions for adultery, go through monetary damages, suffer from emotional distress and so on.

Charity claims herself guilty for her son's disease development caused by the nervous breakdown after the parents' divorce. This signals Charity's stereotyped apprehension of a wife's and mother's role in the family: "a wife's adultery was historically seen as proof of parental unfitness in child custody proceedings"

${ }^{12}$ McAdams D. P. et al. Continuity and change in the life story: A longitudinal study of autobiographical memories in emerging adulthood. Journal of Personality. 2006. Vol. 74. P. 1376.

13 Grysman A. et al. The influence of gender and gender typicality on autobiographical memory across event types and age groups. Memory \& Cognition. 2016. Vol. 44. P. 857.

14 Grysman A. et al. The influence of gender and gender typicality on autobiographical memory across event types and age groups. Memory \& Cognition. 2016. Vol. 44. P. 857.

${ }^{15}$ Miller A. Punishing Passion: A Comparative Analysis of Adultery Laws in the United States of America and Taiwan and their Effects on Women. Fordham International Law Journal. Vol. 41. Issue 2. P. 433. 
Having committed adultery which she longed so much for, Charity does not enjoy satisfaction but undergoes a serious trial, thus verifying the long-rooted stereotype that "wives and mistresses are often cited as suffering social disadvantages that outweigh those of their male counterparts" $"$.

The primary conflict of the novel is patterned as person vs himself/herself. In the early stages of rising action, the female protagonist perceives her fate:

Charity had had four children because she wanted to. $<\ldots>$ The four of them, taken as a package, represented their mother's first understanding of her place in the world ${ }^{17}$.

The woman's devotion to family and children had to direct her life and the plot, but Charity is a contemporary lady and is interested in feminists' ideas (she reads Spare Rib, by the way). This fact defines her further career:

She'd been working for some years in a university department of sociology. She did this as a necessary change from domesticity, the other half of the successful woman's image ${ }^{18}$.

As it can be seen from the fragment, it is necessary to combine a family and a job for a woman to be successful. The male dominated plot would hardly introduce a conflict where a protagonist should have either to choose or the combine the two issues.

The protagonist revolts and tries to cope with her passion. Charity's protest against a love affair looks exactly feminine-like: right ${ }^{, 19}$.

'I can't possibly be in love with you; you're my boss, it wouldn't be

Charity tries to change her life but she does it in a totally feminine way: "Men and women differ psychologically in the way they act, from the style in which they communicate to the way in which they attempt to influence others" ${ }^{20}$. She is so tightly bound to her relations that her connectedness makes new relations more painful than rewarding.

${ }^{16}$ Miller A. Punishing Passion: A Comparative Analysis of Adultery Laws in the United States of America and Taiwan and their Effects on Women. Fordham International Law Journal. Vol. 41. Issue 2. P. 445.

${ }^{17}$ Oakley A. The Men's Room. London: Flamingo, 1991. P. 4.

18 Oakley A. The Men's Room. London: Flamingo, 1991. P. 5.

${ }^{19}$ Oakley A. The Men's Room. London: Flamingo, 1991. P. 26.

20 Merchant K. How Men and Women Differ: Gender Differences in Communication Styles, Influence Tactics, and Leadership Styles. Senior Thesis. 
Charity's husband hit her across the face ${ }^{21}$ and she felt victimized hence reproducing the deep-rooted stereotype that "In cases of sexual infidelity, male aggression is deemed reasonable because a cheating wife is more shameful than a cheating husband" 22 . She encountered physical and psychological male aggression which arose as her husband's behavioral response to her adultery confession; he committed an act of rude agency protesting against the split marital connectedness.

Concerning connectedness as a marker of feminine discourse structuring, the following fragment may serve an extended example of the concept in question:

For Charity, life was no longer essentially magical; it had been overcome by routine. The children's schools started again on 2 September. In the preceding week, she was busy organising their clothes; washing, cleaning, purchasing and labeling. She took Dan and Harry and Rachel to have their hair cut, and sent Tom down the road with instructions about what to have done to his. Then she took Rachel to the doctor for her booster immunisations. She also began to autumn-clean the house, turning out cupboards and excavating under beds, pulling down curtains and discovering dead plants. No cupboard was safe from her house-wifely skirmishes, and even the goldfish got a new lease of life as she bought an electronic test meter to determine the hardness of the water in which they swam and had their being ${ }^{23}$.

Here, a number of enlisted events happened to the protagonist showing her multiple connections: to her children (Dan, Harry, Rachel, Tom), to her pets (goldfish), to her children's schools (she knew the date when they started and adjusted all the preparations to the date), to her house (she used to clean it every autumn). All the described events constitute a stereotyped feminine "routine" which makes up the protagonist's life. They are absorbing but not rewarding thus may be described as feminine. Charity's overcommitment is directed to the wellbeing of her nearest and dearest but this dedication is unnoticed in all the chores she has to complete. She sacrifices her time to the family welfare

Claremont McKenna College. CMC Senior Theses. 2012. Paper 513. URL: http://scholarship.claremont.edu/cmc_theses/513. P. 16.

${ }^{21}$ Oakley A. The Men's Room. London: Flamingo, 1991. P. 70.

${ }^{22}$ Miller A. Punishing Passion: A Comparative Analysis of Adultery Laws in the United States of America and Taiwan and their Effects on Women. Fordham International Law Journal. Vol. 41. Issue 2. P. 456.

${ }^{23}$ Oakley A. The Men's Room. London: Flamingo, 1991. P. 48. 
and considers it matter-of-fact and proper. This principle fits the longexisted theory ("It is often assumed that women are naturally more altruistic than men, especially their own offspring" 24 ) stating that women are born caregivers ("Our culture continues to define care in feminine terms" ${ }^{, 25}$ ) while men are valued for their brains. Some scholars explain this phenomenon from the ontological positions: "physiological differences between man and women, in particular the effect of male hormones such as testosterone on physical and emotional development, make men more self-assertive, aggressive, dominant and competitive, on average, than women are" ${ }^{26}$. Such reasons have been suggested to explain and even justify inequality between sexes in career promotion and housekeeping.

Charity is opposed in her feminist ideas. Her counterpart is her lover, Mark Carleton. She perceives him a stereotype male when he initiates their love affair. She considers him bold and decisive. Her assuredness disappears when the passion weakens and Mark seeks the other romantic adventure. In her eyes, it is weak and unmanly. She is not alone in her suggestions: men are stereotypically blamed and reproached if they violate prescriptive stereotypes by lacking agency and showing weakness $^{27}$. Uncertainty, indecision, embarrassment govern the male rudeness contaminating their once rational abstract mind.

\section{2. "Matilda's Mistake"}

Can assertiveness and career ambitions negotiate with "natural" feminine traits stereotypically ascribed to anyone born a woman? Does a feminist worldview strengthen or weaken connections in McAdams' interpretation? Does agency prevail connections when it comes to a kind of contest between professionals of different sexes? The novel "Matilda's

${ }^{24}$ Folbre N. (2010). The Milk of Human Kindness. Global Perspectives on Gender and Work: Readings and Interpretations, edit. J. Goodman. Plymouth: Rowman \& Littlefield Publishers, Inc. 2010. P. 148.

${ }^{25}$ Folbre N. (2010). The Milk of Human Kindness. Global Perspectives on Gender and Work: Readings and Interpretations, edit. J. Goodman. Plymouth: Rowman \& Littlefield Publishers, Inc. 2010. P. 154.

${ }^{26}$ Hakim C. Work-Lifestyle Choices in the $21^{\text {st }}$ Century: Preference Theory. New York: Oxford University Press Inc., 2002. P. 221.

27 Moss-Racusin C. A. et al. When men break the gender rules: status incongruity and backlash toward modest men. Psychology of Men and Masculinity 2010. Vol. 11. P. 140-151. 
Mistake" leaves these problems unsolved and encourages the readers to suggest their solution.

This is a rare case in literature when one of the plotlines depicts friendship between women. In "Matilda's Mistake", it is friendship between Willow Cornford, an American married to an Englishman, and Matilda Cressey, a British journalist (Willow and Matilda met when Matilda did an MA in journalism in Minnesota in $1976^{28}$ ). This fact was neither "a static auxiliary" to the central plot development nor a "symptomatic exclusion from it" but rather a "transmission mechanism",29 that facilitated the key conflict to originate and gave reason to some events. Taking into account the stereotyped American attitude towards everything as compared to European rendered by Willow, and Matilda's energetic discposition (Matilda is good at making lists, it's one of the skills that got her this job in the first place ${ }^{30}$ ) and high job position (she is President of the Council for Consumer Affairs), the friendship between the two ladies seems more like business relations. Their meetings are always caused by some pragmatic reason. For example, Willow knew both of Matilda's previous professional experience and her new longawaited appointment (She is pleased to be here, as after fifteen years in journalism it dawned on her that she was unlikely to get a major editorial $j o b^{31}$ ) and decided to ask her friend for a favour requiring her professional skills and present job. She would like Matilda to undertake some investigation of an Alternative Birth Centre - a private clinic offering services of "natural childbirth". The friends made an agreement and the rising action begins.

Desire for love, affection often become motivational themes for "ego development", "psychological well-being", and "personal growth"32 of a female character what triggers plot events succession. In a plot, the concentration of female values and needs falls on a climax which reveals all the secrets or missing points in the story. As far as a stereotyped

${ }^{28}$ Oakley A. Matilda's Mistake. Flamingo, London, 1991. P. 17.

29 Marcus Sh. Between Women: Friendship, Desire, and Marriage in Victorian England. Princeton: Princeton University Press, 2007. P. 3.

${ }^{30}$ Oakley A. Matilda's Mistake. Flamingo, London, 1991. P. 12.

${ }^{31}$ Oakley A. Matilda's Mistake. Flamingo, London, 1991. P. 12.

${ }^{32}$ McAdams D. P. et al. Continuity and change in the life story: A longitudinal study of autobiographical memories in emerging adulthood. Journal of Personality. 2006. Vol. 74. P. 1376. 
woman is assumed to aspire for mutual love resulting in a marriage, A. Oakley introduces this traditional episode into the novel:

"So, what's the discussion you want us to have, Matilda?"

"I want to know what we're doing here together, Steven."

"I would have thought it was obvious," he says.

"I don't want to have just another relationship."

$<\ldots>$

"You want me to stop the world and get off. You want to marry me.”

"Yes." It takes courage for her to say this little word, and then to look at him in the smoky atmosphere and await his response $e^{33}$.

The female protagonist initiates unraveling of relations with her lover. She would like the situation to be clear, their statuses to be distinct and herself to be sure in her future. Matilda demonstrates agency for the sake of connectedness. She starts a conversation, she sets a problem and she wants the problem to be solved. In her favour, of course. She succeeds:

Steven takes Matilda to Lindroos on Aleksanterinkatu and buys her a silver Lapponia ring. The design is pleasingly angular, like ab Alvar Aalto library. Matilda enjoys twisting it round on her finger ${ }^{34}$.

The verbal marker of Matilda's "achievement" is a ring, a symbol of the engaged status. The further succession of events proves Matilda has reached her final goal: she married Steven and got another symbol confirming this status: a ring:

Matilda, in ice-blue silk, slips her Lapponia ring on the same finger as her wedding ring after the ceremony and feels properly married: two rings on the same finger, that's the true sign ${ }^{35}$.

The two rings stand for a marital status and signal such protagonist's traits of character as determination and resoluteness. Finally, she establishes new connectedness but only after activation of agency. She is satisfied with the result what is signified by a word properly. Its dictionary definition ("in a manner that is suitable for the purpose or situation; in a way that is considered right or correct; really, or completely"36) correlates with tradition and stereotype. So, the evident conclusion consists in the fact that no matter what progressive and

${ }^{33}$ Oakley A. Matilda's Mistake. Flamingo, London, 1991. P. 107.

${ }^{34}$ Oakley A. Matilda's Mistake. Flamingo, London, 1991. P. 107.

35 Oakley A. Matilda's Mistake. Flamingo, London, 1991. P. 163.

${ }^{36}$ Macmillan Dictionary. URL: https://www.macmillandictionary.com. 
feminist outlook the protagonist demonstrates, she sticks to the patriarchal tradition of official marriage with all its attributes. Besides, the lexeme proper(ly) is one of the recognizable features of Ann Oakley's literary style (see, for example, her novel "A Proper Holiday" where this word acquires a strong position, i.e. the title, and goes through all the text as a key concept).

Climax isn't always the most important scene in a story. In many stories, it may have no successive falling action or denouement, otherwise the author encourages the reader to predict the continuation or resolution. The same refers the final remarks of the text. When the two key characters of the novel - protagonist (Matilda) and antagonist (Steven) - marry and the story seems to come to its happy end there appears something that excites the reader's interest at the very last page. There is a short dialogue between Matilda and Steven while they are making love:

M.: "Are there things you haven't told me about your past?"

S.: "Of course not. I mean yes, obviously, but nothing important",37.

There are unanswered questions and, accordingly, unresolved problems challenging Matilda in future. But there is no way back:

It's over quickly but it's only a beginning, as ovum and sperm conjoin in the darkness of Matilda's left fallopian tube ${ }^{38}$.

The fragment implies that the final of the previous event (over) switches over to the new one (beginning). Matilda's getting pregnant signals a new event, a new character, a new kind of relations and connectedness. But it is the last sentence of the novel, and the readers have to unwind this imaginative knot themselves.

In terms of McAdams' connectedness, the whole narration presents links, connections, relations etc. Here belong friendship between Matilda and Willow, marital relations between Willow and Antony, family links between Matilda and her parents, Matilda and William's civil marriage, connections between Steven van den Biot and the patients of his clinic - pregnant women, professional relations and later - love affair between Steven and Matilda, Steven's unexpected encounter with his first love Béatrice and sweet memories of youth, the atmosphere between the employees in Matilda's office - all of them women, family relations between Lady Claudia Foxman and her husband, love affair between Lord

${ }^{37}$ Oakley A. Matilda's Mistake. Flamingo, London, 1991. P. 167.

${ }^{38}$ Oakley A. Matilda's Mistake. Flamingo, London, 1991. P. 167. 
Foxman and his mistress, Lady Foxman's romantic feelings and sexual appeal towards Steven and a lot of others. The narrative progression of the novel binds several plotlines where the conflict grounds on some connection with a feminine character being involved. There is not a single description of relations between men only. In fits Judith Butler's theory of identity formation through discoursive practices ${ }^{39}$. Ann Oakley's individual style bears the signals of gender construction, unlike a born sex. This gender identity formation is going on in a fiction text in the form of a plot.

The postmodern frame of the novel's messages and structures asserts the interpretation of identity represented on its pages. The characters' self-perception, self-expression, self-actualisation is verbalized according to the author's selection of lingual instruments. Here, the author's cognitive processes of creating and textualising character images bears the impact of postmodern philosophy where the idea of "self" is only perceptible in relation to "other" $"$. Such correlation and to some extent juxtaposition provides a person with a sense of belonging, connection; affiliation with some community (family, job, friendship etc.) ensures relations, ties and their development. In a text, it results in plot succession.

\section{3. "A Proper Holiday"}

Both men and women benefit from leisure pastime. The plot of "A Proper Holiday" is a picture of English families having their vacation in Turkey. The novel abounds in events and characters. From the first pages, the rhysoma plot structure makes it difficult to identify the number and succession of events.

The analysis of the novel proves that whatever happens in a text, happens for a reason. The cause-and-effect sequence binds all the plot elements together forming a plot line(s). Despite the splitting into multiple story lines, a literary text recreates real life in all its riches and multifacetness. The central theme unites all plot components into a single unit - a text, a cohesive and coherent verbal unit.

${ }^{39}$ Butler J. Gender Trouble: Feminism and the Subversion of Identity. New York: Routledge, 1990. 272 p.; Butler J. Bodies That Matter, on the Discursive Limits of Sex. New York \& London: Routledge, 1993. 256 p.

${ }^{40}$ Hall S. Introduction: Who Needs Identity? Questions of Cultural Identity, edit. Hall S. and du Gay P. London: SAGE, 1996. P. 17. 
The feminine bias of the novel is noticeable from its very beginning: one of the protagonists, Crispin Delancey, having just arrived at the Turkish hotel for a package holiday, observes a woman swimming in the pool and involuntarily compares her with his wife. His represented inner speech expresses his attitude towards them both. The verbal means serve the character descriptions:

She was thirty-ish, he supposed. Her compact body wore a yellow bikini like a second skin. She had light, crinkly hair which sparkled in the sharp mid-morning sunlight, creating altogether the appearance of a svelte, illuminated lemon ${ }^{41}$.

Here, the new acquaintance is depicted by verbal units with positive meaning, for example, compact body, like a second skin, svelte which sound like compliments to a good-looking person. There are several words united by "light" semantics; the word light in hair description; the lexeme sunlight symbolizes the sun - a source of light, energy, life and growth; sparkle and illuminate stand for light and brightness, too; morning stands for sunrise, a new day, new expectations. The meaning of "light" is extended by its tints: yellow (bikini) and lemon. Besides, the suffix - ish denotes "used with many adjectives to make other adjectives meaning slightly or fairly; used with many numbers to make adverbs meaning approximately" ${ }^{\text {. }}$. It is objectified the new acquaintance's description whose age is presented in a diminutive perspective which makes a positive association of youth.

On the contrary, Crispin views his wife in a different way:

"You'll burn if you don't do something about it!" A large tapestry bag arrived by Crispin's right ear accompanied by his fun-loving, fattish, forty-something wife, Dodo ${ }^{43}$.

In contrast to the previous verbal portrait, the suffix -ish is attributed to the general description of Dodo's appearance (fattish). It is not in the wife's favour compared to the previous woman's portrayal but with different verbalization (svelte, compact body). The wife's age is forty-something which is at least ten years more than thirty-ish. What's more, it indicates the husband's ignorance of his wife's exact age. Judging from the events sequence, the first thing Crispin noticed was a bag (large tapestry bag), his wife was just its accompaniment. The only positive

\footnotetext{
${ }^{41}$ Oakley A. A Proper Holiday. Flamingo, London, 1996. P. 1.

${ }^{42}$ Macmillan Dictionary. URL: https://www.macmillandictionary.com.

${ }^{43}$ Oakley A. A Proper Holiday. Flamingo, London, 1996. P. 1.
} 
semantics arises from the attribute fun-loving but it is too weak to combat the pretty stranger.

So, the love triangle is drawn on the first page. It layers the plot making the narrative development easy to predict. Ann Oakley tries to play with the conventions of this tool in her own way making all the three participants of this geometry figure enjoy the vacation differently. She signals to the reader that none of the three is going to suffer having come to such a faraway country to have "a real holiday - one without obligations, without routines, in which one was absolutely free to - well, have a holiday"44. But is this holiday "proper"? The key lexeme in the strong position - the title of the book - implies its denotative meaning ("suitable for a purpose or situation; considered to be morally good; considered to be real or serious; complete in every detail" ${ }^{\prime 4}$ ). By the end of the novel it becomes clear that the attribute "proper" possesses multiple interpretations depending on many circumstances: sex, gender, age, education, social background, profession, nationality, religion, surrounding etc. There are several plotlines concentrating on many characters, and each of them treats "proper" in his/her own way. And behaves respectively.

Taking into account that "narrating is an activity for creating identity as well as for sharing experience" $" 46$, the author forms different identities, both as literary heroes and social constructs (sharing her personal experience of a sociologist and feminist). Ann Oakley portrays the Europeans (the British in particular) who let themselves relax too much violating social norms and human morals. It results in their children's escape, the rampageous fact that even mass media write about. It is a feminine voice, that of a Turkish woman Bilge, that calls on to them with accusations and supplication to come to their senses:

"You're sick and stupid and selfish. You don't deserve your children, no wonder they've run away from you! You're none of you fit to be parents! You should be ashamed of yourselves." There were tears in her eyes, and the red of her hotel uniform ran with sweat. She fell full of heat and feeling and tiredness, and she wanted to go on shouting at them

${ }^{44}$ Oakley A. A Proper Holiday. Flamingo, London, 1996. P. 2.

${ }^{45}$ Macmillan Dictionary. URL: https://www.macmillandictionary.com

46 Daiute C. Narrative Inquiry: A Dynamic Approach. New York: SAGE Publications Inc., 2014. P. 15. 
and hurting them until they all came to their senses and understood what she was trying to tell them ${ }^{47}$.

This desperate shout is supported by another woman - an elderly lady, a former intelligence officer Wilma Blake:

"Mind you," said Wilma, gripping her handbag, "I've got some sympathy with Bilge's point of view."

$<\ldots>$

“Well, look at you all. You're a dissolute lot, aren't you! No wonder your youngsters ran away from you!",48.

These two female characters (Bilge and Wilma) are keepers of traditional morals neglected by the contemporary European societies. They imply the stereotypical feminine function of caretaking and family guarding. Ann Oakley introduces a character of Wilma Blake, an elderly woman, a keeper of traditional moral but not devoid of analytical consideration, and communicates the long-lived values which have survived even under feminist influence and explicate "social harms that befall women over men in adulterous situations" 49 .

The narrative of the novel serves a fragment of the contemporary British reality where representatives of different social strata explicate the way of their functioning in community. The links binding the society into an active and progressing unity serve signs of connectedness realized in the texts. The scope of "immediate constituents" of a narrative is being extended nowadays what does not remain unnoticed by scholars. Take, for example, R. Franzosi's observation stating that "besides social relations, concepts and ideas also stand in relation to each other, with words distributed in conceptual spaces" ${ }^{, 50}$. The moral norms regulating interactions within the depicted community are grounded on socioeconomic dimensions and the conception of morality as the whole nation's guidepost. It proves the suggestion that "socio-economic conditions may affect the function, and perhaps the development, of at least some of the brain areas and structures associated with emotion and

${ }^{47}$ Oakley A. A Proper Holiday. Flamingo, London, 1996. P. 198.

${ }^{48}$ Oakley A. A Proper Holiday. Flamingo, London, 1996. P. 201.

49 Miller A. Punishing Passion: A Comparative Analysis of Adultery Laws in the United States of America and Taiwan and their Effects on Women. Fordham International Law Journal. Vol. 41. Issue 2. P. 447.

50 Franzosi R. Quantitative Narrative Analysis. Thousand Oaks: SAGE Publications, Inc., 2010. P. 52. 
cognition"51. In the novel, these conditions trigger the scope of connections binding the heroes into a system of characters. In contrast to seemingly diverse sets of traits the depicted characters possessed, there are some unifying aspects.

\section{Postmodern Feminine Identity}

The novels under discussion fit the matrix of postmodern writing. At times, the narrative breaks the conventional unity and dashes into unexpected composition shifts. One of them is fragmentation which seems to undermine the text unity and swings the centre. Giving prominence to fragmentation enables Ann Oakley to introduce several plotlines with a protagonist and a message in each. Fragmentation serves a liberation force facilitating the appearance of various if not contrasting characters thus painting the picture of contemporary society free from fixed systems of beliefs, regulations, values, and obligations. This patchwork of literary characters' portraits displays the heterogeneous composition of the British social strata of late $20^{\text {th }}$ century. This corresponds to the rejection of "metanarratives" as found in J.-F. Lyotard's book "The Postmodern Condition: A Report on Knowledge" 52 where the philosopher and literary theorist advocates the idea of multiple "mininarratives". They are more specific and can immediately and precisely depict particular events, people, objects in definite circumstances, within peculiar textual forms etc.

Fragmentation can be observed in all the three texts under analysis but it is most vivid in "A Proper Holiday". At first sight, the fragmented system of characters seems to generate discontinuity and hybridity of the text as a whole. Here, the reader encounters families (the Delanceys, the Dunkerleys, the Uptons, the Hollbeaches, the Shaws) each of which leads its own story and each of them splits into older and younger generations. The connections are intertwined, morals are violated on all age levels, the generation gap comes to the fore exposing the total indifference on the part of the parents and outburst of protesting moods on the part of their teenage children. The "feminine" tint of this fragmentation consists in the

${ }^{51}$ Caravita S. et al. Socio-Economic Factors Related to Moral Reasoning in Childhood and Adolescence: the Missing Link Between Brain and Behaviour. Frontiers in Human Neuroscience. 2012. Vol. 6. P. 3.

${ }^{52}$ Lyotard J.-Fr. The Postmodern Condition: A Report on Knowledge. 1979. Transl. by G. Bennington and B. Massumi. Minneapolis: University of Minnesota, 1984. 135 p. 
fact that there is a female character in each group and this very character influences the plot development.

In postmodern fiction, an identity presentation does not totally depend on the author's ideas directly expressed in a text or proclaimed by characters themselves. It is often implied in details and concealed "between lines". The transparency of a character's identity explication arises from the lingual means depicting his/her lifestyle and consumption. The comforting stability of the character's traits peculiar for, for instance, classical novels is alien to postmodern identity. In Ann Oakley's books, a reader encounters individuals whose identity is embedded in plentiful events constituting the plotline. So, lifestyle choices become vital for text identity framing and narrative development. In the novels in question, this identity is predominantly feminine.

Feminine identity in the novels under analysis can boast of multiplicity of signifiers. If the direct nomination remains unspoken or unexpressed, the effective implication hidden under the denominative folds of the narrative comes out in completely unexpected contexts. Consider, for example, a stereotyped tradition of a wife to take her husband's surname in marriage. Matilda from "Matilda's Mistake" sticks to a different principle:

"It's for Les, Miss Cressey - whoops! Mrs van den Bore-it," she explains later. $<\ldots>$

"It's all right, Margaret," says Matilda, "and I'm not going to change my name. You can stick with the old one. It's easier anyway."

"That's right," says Margaret's sister Lesley that evening. "I approve of that."

"You do, Les?"

"Course I do. She's a professional woman, got a career of her own. Doesn't want to be an appendage of his, does she? ",53.

In the fragment, there are several verbal signals identifying the protagonist as a postmodern type of a feminine identity. The patriarchal nominations like Miss and Mrs seem outdated to a younger colleague what explains her mocking at them. Matilda announces her independence in matrimony by proclaiming her desire to retain her maiden name ( $I$ 'm not going to change my name). The statement is quite unexpected as far as the tradition to acquire a new surname is a deep-rooted one. She is not alone in her creed and is supported by the other feminine character,

${ }^{53}$ Oakley A. Matilda’s Mistake. Flamingo, London, 1991. P. 164. 
Lesley, whose arguments refer exclusively to Matilda's professional value (a professional woman, got a career of her own). According to the text, only professional achievements raise a woman's self-esteem and social rank; otherwise she is bound to be a man's shadow (to be an appendage of his). The protagonist rejects the socially expected connections. If so, the abstract allows to derive some vistas for the further development of events after the narrative is over and the reader closes the book: is the new family's life going to be cloudless and smooth if the wife proclaims selfesteem and self-assurance and her husband is much older than her? will the relations within the family change in case Matilda's career promotion does not progress? Ann Oakley leaves many questions for a curious reader to ponder on yet the only point remains evident: any development or continuation of the plot are feminine-focused, female coloured.

\section{CONCLUSIONS}

Ann Oakley constructs culturally relevant identities. A diverse range of female characters accumulates the postmodern worldview. On the one hand, these are individuals with distinctive traits and established values; on the other - they exemplify lack of autonomy, consumption dependence and reference to the synchronic paradigm in its broad sense.

The "feminine" features of the analysed novels are identified in such aspects: the events that trigger the plot development are brought about by a female character; these events arise from the female character's connectedness (family, job, romance) and are specified by a traditionally accepted feminine approach towards their qualification and evaluation; as far as the three novels bear the signals of postmodern philosophy there are obvious transformations noticeable in female characters representation, in particular, their acquirement of agency features translated through the female activity, resoluteness, determinism implemented in both the narrative flow and lingual units.

\section{SUMMARY}

The paper concerns the significance of identity explication in a plot development. Verbal means of feminine identity representation are considered to be text constructs determining the contents and succession of plot events. The concepts of agency and connectedness serve the matrix within which feminine and masculine characters are treated as bearing stereotyped traits. The study of Ann Oakley's novels "Matilda's Mistake", "The Men's Room", and "A Proper Holiday" proves that the scope of events and the way of their narration are derived from the 
socially and culturally approved system of values, beliefs, morals etc. traditionally attributed to women. The impact of postmodern philosophy upon the analysed texts is traced in the transformations of female characters where the elements of agency and connectedness are often interchanged and intertwined.

\section{REFERENCES}

1. Grysman A. et al. The influence of gender and gender typicality on autobiographical memory across event types and age groups. Memory \& Cognition. 2016. Vol. 44. P. 856-868.

2. Ellemers N. Gender Stereotypes. Annual Review of Psychology. 2018. Vol. 69. P. 275-298.

3. Mansfield E. D., McAdams D. P. Generativity and themes of agency and communion in adult autobiography. Personality and Social Psychology Bulletin. 1996. Vol. 22. P. 721-731.

4. McAdams D. P. et al. Continuity and change in the life story: A longitudinal study of autobiographical memories in emerging adulthood. Journal of Personality. 2006. Vol. 74. P. 1371-1400.

5. Bakan D. The duality of human existence. Boston: Beacon Press, 1966. 242 p.

6. Miller A. Punishing Passion: A Comparative Analysis of Adultery Laws in the United States of America and Taiwan and their Effects on Women. Fordham International Law Journal. Vol. 41. Issue 2. P. 425-471.

7. Constantinople A. Masculinity-femininity: an exception to a famous dictum? Psychological Bulletin. 1973. Vol. 80. P. 389-407.

8. Shapin S. The Science of Subjectivity. Social Studies of Science. 2011. Vol. 42 (2). P. 170-184.

9. Longo M. Fiction and Social Reality. Literature and Narrative as Sociological Resources. London and New York: Routledge, 2016. $176 \mathrm{p}$.

10. Davidson H. M. The literary representation of reality. Res Cogitans. 2018. Vol. 13 (1). P. 111-134.

11. Merchant K. How Men and Women Differ: Gender Differences in Communication Styles, Influence Tactics, and Leadership Styles. Senior Thesis. Claremont McKenna College. CMC Senior Theses. 2012. Paper 513. URL: http://scholarship.claremont.edu/cmc_theses/513.

12. Oakley A. The Men's Room. London: Flamingo, 1991. 312 p.

13. Folbre N. (2010). The Milk of Human Kindness. Global Perspectives on Gender and Work: Readings and Interpretations, edit. 
J. Goodman. Plymouth: Rowman \& Littlefield Publishers, Inc. 2010. P. 147-158.

14. Hakim C. Work-Lifestyle Choices in the $21^{\text {st }}$ Century: Preference Theory. New York: Oxford University Press Inc., 2002. 360 p.

15. Moss-Racusin C. A. et al. When men break the gender rules: status incongruity and backlash toward modest men. Psychology of Men and Masculinity 2010. Vol. 11. P. 140-151.

16. Oakley A. Matilda's Mistake. Flamingo, London, 1991. 167 p.

17. Oakley A. A Proper Holiday. Flamingo, London, 1996. 216 p.

18. Marcus Sh. Between Women : Friendship, Desire, and Marriage in Victorian England. Princeton: Princeton University Press, 2007. 368 p.

19. Macmillan Dictionary. URL: https://www.macmillandictionary.com

20. Daiute C. Narrative Inquiry: A Dynamic Approach. New York: SAGE Publications Inc., 2014. 320 p.

21.Butler J. Gender Trouble: Feminism and the Subversion of Identity. New York: Routledge, 1990. 272 p.

22. Butler J. Bodies That Matter, on the Discursive Limits of Sex. New York \& London: Routledge, 1993. 256 p.

23. Caravita S. et al. Socio-Economic Factors Related to Moral Reasoning in Childhood and Adolescence: the Missing Link Between Brain and Behaviour. Frontiers in Human Neuroscience. 2012. Vol. 6. P. 1-14.

24.Lyotard J.-Fr. The Postmodern Condition: A Report on Knowledge. 1979. Transl. by G. Bennington and B. Massumi. Minneapolis: University of Minnesota, $1984.135 \mathrm{p}$.

25. Hall S. Introduction: Who Needs Identity? Questions of Cultural Identity, edit. Hall S. and du Gay P. London: SAGE, 1996. P. 1-17.

26. Franzosi R. Quantitative Narrative Analysis. Thousand Oaks: SAGE Publications, Inc., 2010. 200 p.

Information about the author: Alla Marchyshyna, Doctor of Philological Sciences, Associate Professor at the Department of the English Language, Kamianets-Podilskiy National Ivan Ohiienko University 50/53, Hrushevskoho ave., Kamianets-Podilskiy, 32300, Ukraine 
DOI https://doi.org/10.36059/978-966-397-194-0/99-131

\title{
THE METHODOLOGY OF THE MODELLING OF THE FRACTAL POETICAL MODEL OF THE WORLD (BASED ON THE BRITISH POETRY OF THE XIX ${ }^{\mathrm{TH}}$ CENTURY)
}

\section{Oksana Moskvichova}

INTRODUCTION

\begin{abstract}
To see a World in a grain of sand, And a Heaven in a wild flower, Hold Infinity in the palm of your hand,

And Eternity in an hour. (W. Blake "Auguries of Innocence", )
\end{abstract}

In the mathematics, in the computer science, in the fractal geometry, in the theory of systems, and in the synergetics 'the fractal' (from the Latin 'fractus' - 'to break, to destroy') - is identified as the object that is characterized by the fractional structure having the hierarchical level of the organization; as the endless geometrical figure every fragment of which is repeated in the reduced scale ${ }^{2}$. In the academic scientific world the leading role in the generation of the theory of fractals belongs to the mathematics because fractals have been identified by the mathematician Benoit B. Mandelbrot in his scientific research "The Fractal Geometry of Nature"3. Benoit B. Mandelbrot generated fractals by means of the mathematical and computer calculations and the researches of the coastline of Great Britain. Fractals have been investigated deeply in the mathematics but this term belongs also to the sphere of the synergetics, the science that comprises the physics and the mathematics, and has been integrated into the linguistics being the interdisciplinary direction of the scientific researches in the aspect of which are investigated processes of the transition from the chaos to the order and (in English)

${ }^{1}$ Blake W. (2019) The Selected Poems. London : Wordsworth Poetry Library.

${ }^{2}$ Demenok S. L. (2018) Prosto fraktal. [The Simple Fractal]. Sankt-Peterburg : Strata. (in Russian)

${ }^{3}$ Mandelbrot B. B. (1982) The Fractal Geometry of Nature. New York : W. H. Freemanand Company. (in English) 
vice versa in the open nonlinear spheres of the different nature ${ }^{4}$. In the article we are served by the dominant role of the exploration of the fractality in the mathematics because in the process of the constructing of the fractal poetical model of the world we rely on the postulates of the mathematical modelling of fractals.

The aim of the article is to describe the process of the modelling of the fractal poetical model of the world in the linguistic and the cognitive aspects on the basis of the British poetry of the XIX $-\mathrm{XXI}^{\text {st }}$ centuries.

The object of the scientific research is the fractal poetical model of the world in the British poetry of the XIX - XXI ${ }^{\text {st }}$ centuries. The subject the cognitive and the fractal potential of literary concepts ${ }^{5}$, conceptual tropes, frames and emergent conceptual blends as verbal means of the modelling of the fractal poetical model of the world on the basis of the British poetical texts of the romantic, the modern and the postmodern periods.

The material of the investigation is presented by the British poetry of the XIX $-\mathrm{XXI}^{\mathrm{st}}$ centuries in the total amount of 3628 poetical texts (4832 pages). For the illustration of the design of the fractal poetical model of the world have been chosen the brightest examples (490 poetical texts on 267 pages).

The methodology of the modelling of the fractal poetical model of the world is polydisciplinary conditioned by the combination of the interpretational, the textual, the descriptive, the semantic, the component, the linguistic, the stylistic, the cognitive, the poetical, the mathematical, the fractal, the geometrical methodology.

\section{The illumination of fractals in the modern scientific paradigm}

The founder of the theory of the fractality Benoit B. Mandelbrot has identified the term 'the fractal' from the Latin words 'frangere' ('to break') and 'fractus' ('ruptured, discrete, fractional'). The word is identical to the English 'fracture' ('the rapture') and 'fraction' ('the fraction'). Except the meaning 'fractional' (in words 'the fraction' and

${ }^{4}$ Demenok S. L. (2018) Superfraktal. [The Superfractal]. Sankt-Peterburg : Strata. (in Russian)

5 Nikonova V., Boyko Y. (2019) Gender-specific emotivity of Victorian female prose from a multidimensional perspective. In Lege artis. Language yesterday, today, tomorrow. Vol. IV (1), pp. 47-82. (in English) 
'the refraction') the word 'fractus' means 'the wrong-shaped'6. Thus, Benoit B. Mandelbrot has modeled the definition of the identified by him term 'the fractal' as for the algorithm and the association from the English 'FRACTionAL'. Even graphically Benoit $\mathrm{B}$. Mandelbrot has written the word 'FRACTAL' from 'FRACTionAL' by means of capital letters in the way the cognitive scientists write identified and verbalized concepts. The conceptual sphere in the field of the cognitive linguistics is graphically represented by the linguists in the similar way to the Circular Apollo Fractal (e.g., (Fig. 1)). Thus, we surmise the existence of the connection between the cognitive linguistics and the fractional mathematical theory in the graphical way.
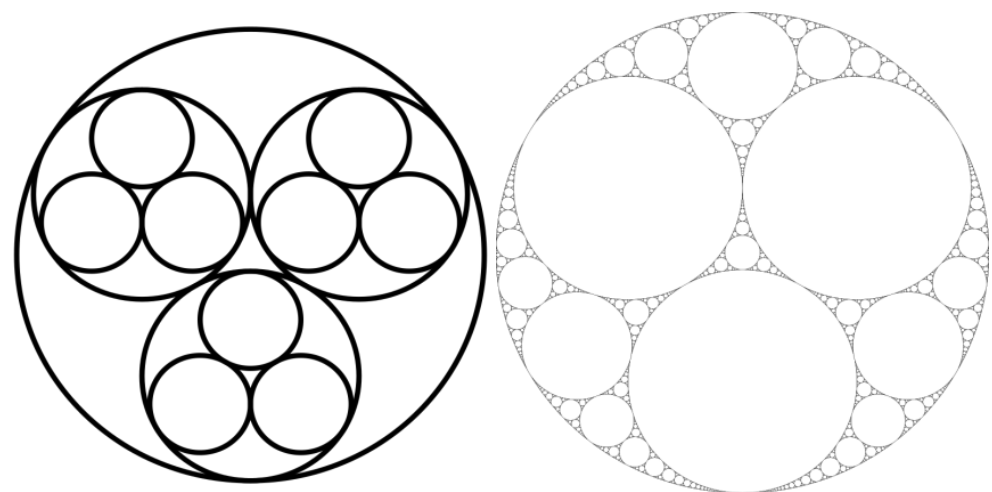

Fig. 1. The Circular Apollo Fractals

Fractals or the mathematical and the geometrical monsters have changed the mathematics of the end of the $\mathrm{XX}^{\text {th }}$ century and after their multidisciplinary integration into different scientific spheres lots of terms and forms have been identified by the scientists in the fractional and the mathematical way. Benoit B. Mandelbrot has summarized different types of fractals, has identified the ways of the fractional computer calculation that have been integrated into the modern fractional computer graphics (e.g., (Fig. 2; Fig. 3; Fig. 4) ${ }^{7}$.

${ }^{6}$ Demenok S. L. (2018) Prosto fraktal. [The Simple Fractal]. Sankt-Peterburg : Strata. (in Russian)

7 Mandelbrot B. B. (1982) The Fractal Geometry of Nature. New York : W. H. Freemanand Company. (in English) 

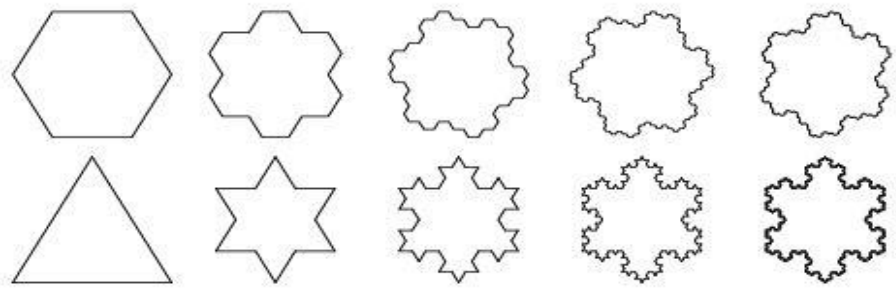

हूल हु हु
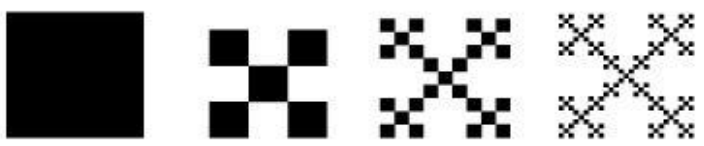

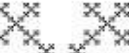

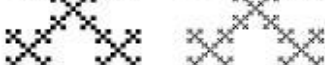
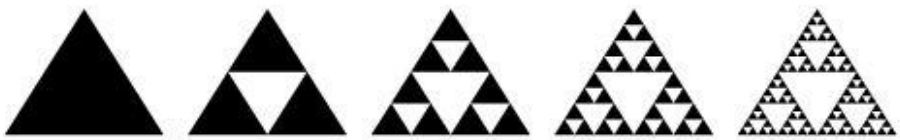

Fig. 2. Types of fractals
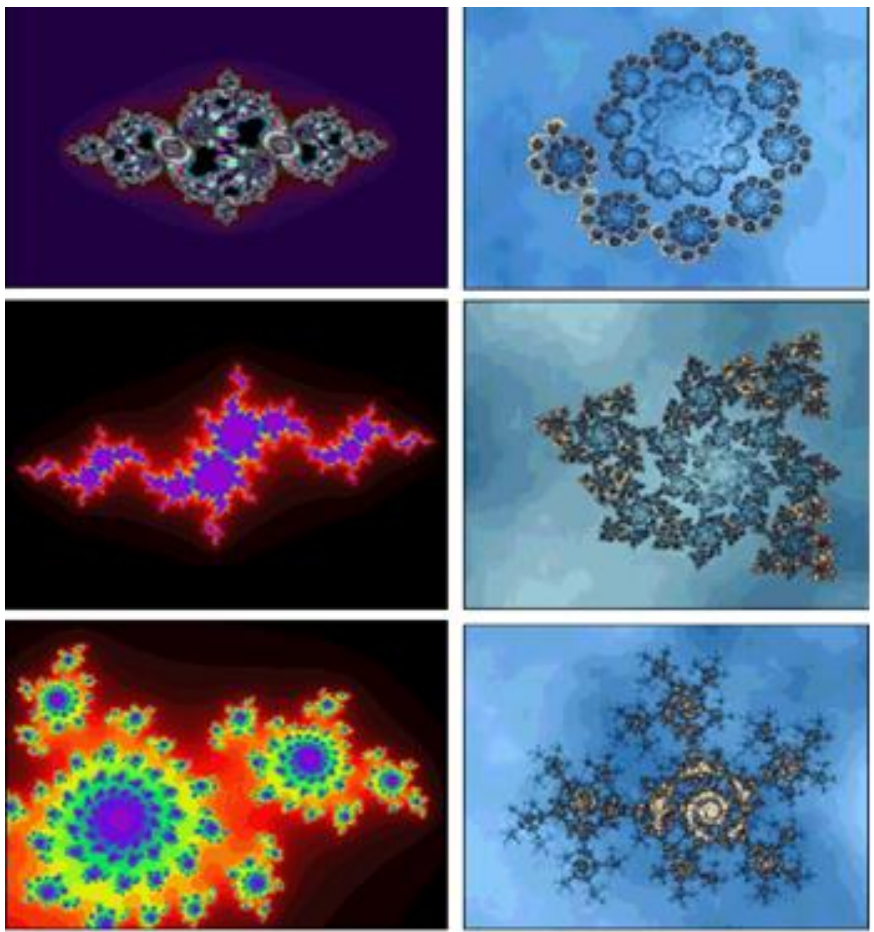

Fig. 3. Types of fractals in the computer graphics 


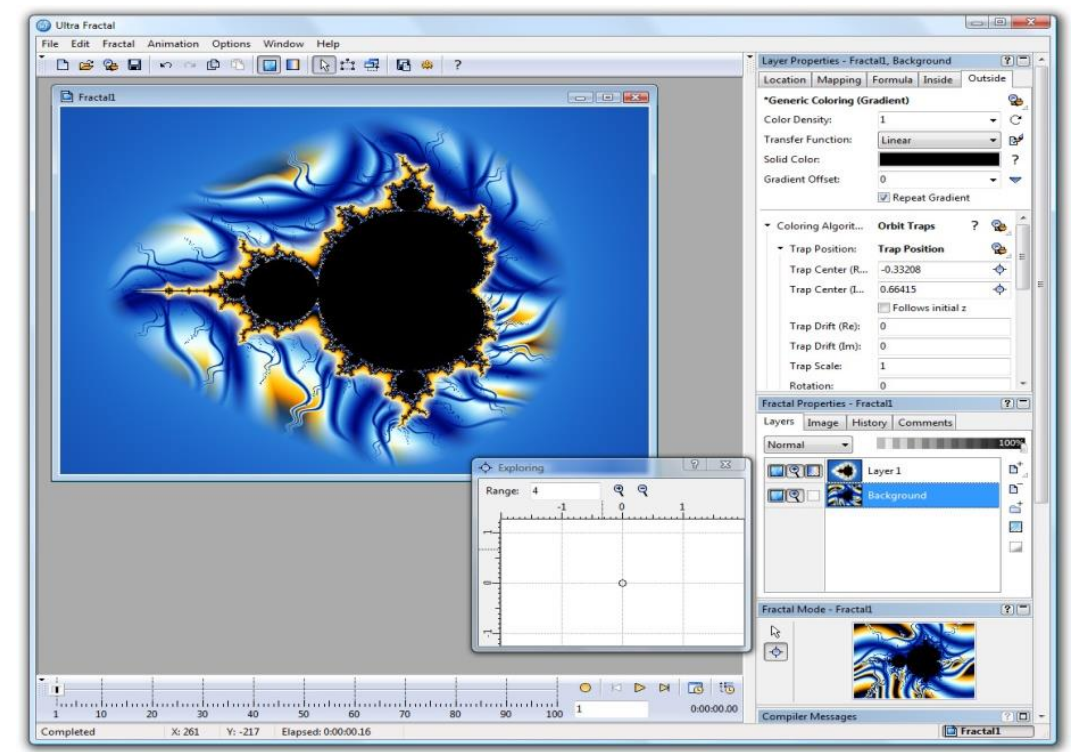

Fig. 4. The computer calculation of fractals in the computer graphics

Benoit B. Mandelbrot has stated that every self-similar fractal element is never-ending because structurally every fractal consists from the smallest or the fractional elements the modelling of which is ruled by the previous elements of the fractal. The fractal is the self-similar and the never-ending unity, the connection between elements of which is determined by the connection between all the elements of the fractal. The construction of the fractal is strict and mathematically determined because every small element of the fractal is the simplified version of the whole fractal. The process of the modelling of the fractal is ruled by the repeated repetition of the analogical mathematical operations - iterations. Fractal iterations are recursive, the final stage of the previous element of the fractal is the beginning of the new stage of the fractal modelling - the iterational fractal process. The fractal modelling is the endless process because fractals have the beginning but don't have the ending and the final stage of the modelling ${ }^{8}$.

${ }^{8}$ Demenok S. L. (2018) Superfraktal. [The Superfractal]. Sankt-Peterburg : Strata. (in Russian) 


\section{The modelling of the fractal poetical model of the world}

Extrapolating the methodology of the linguistic, the poetical, the cognitive analysises of the poetry and considering the results of the fractal modelling in the mathematics, in the fractal geometry, in the synergetics, in the theory of systems we propose the methodology of the modelling of the fractal poetical model of the world on the basis of the British poetry of the XIX $-\mathrm{XXI}^{\text {st }}$ centuries in the linguistic and the cognitive perspectives.

Thus, the fractal poetical model of the world is characterized by the complex structure, the starting point of it's constructing is the strange / the circular / the cyclic fractal attractor (from the Latin 'attrahere' - 'to attract'; from the English 'to attract') ' $^{9}$. The fractal attractor is the starting point of the fractal modelling that is stable and attracts to itself all the trajectory of the whole fractal system or the fractal model. Structurally, in the aspect of the fractal geometrical modelling, the fractal attractor comprises from the central node around which, in the spiral form, are pulverized trajectories of the fractal that never intersect and are concentrated around the central node of the attractor. The strange fractal attractor in the fractal modelling is the trajectory of the fractal orbit that makes possible the fractal modelling to get started in such a way: 'the central node of the strange fractal attractor $\rightarrow$ the cycle $\rightarrow$ the fractal' (e.g., (Fig. 5)):
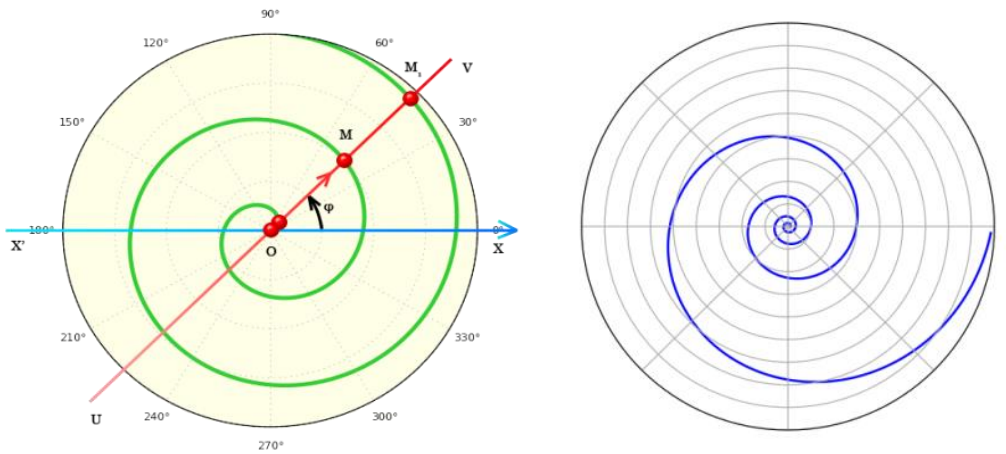

Fig. 5. The trajectory of the fractal modelling from the central node of the strange fractal attractor to the cycle and to the fractal

${ }^{9}$ Demenok S. L. (2018) Superfraktal. [The Superfractal]. Sankt-Peterburg : Strata. (in Russian) 
Integrating the theoretical aspects of the fractal modelling and taking into consideration the actuality of the term 'the strange fractal attractor' in the aspect of the fractal constructing while the modelling of the fractal poetical model of the world we propose to understand under the central node of the attractor the literary concept or literary concepts that are identified by us in the British poetry of the XIX $-\mathrm{XXI}^{\text {st }}$ centuries. The literary concept in the cognitive linguistics and the cognitive poetics is the basic element of the fractal conceptual model of the world that includes linguistic and extra-linguistic aspects determined by historical and cultural traditions of the romantic, the modern and the postmodern periods in Great Britain.

The central node of the fractal poetical model of the world is the literary concept / literary concepts. According to the trajectory of the orbit of the strange fractal attractor the dynamics of the fractal modelling of the poetical model of the world we outline in such an order: literary concepts $\rightarrow$ the basic conceptual tropes (the conceptual metaphor, the conceptual metonymy, the conceptual oxymoron, the conceptual metamorphosis $\left.{ }^{10}\right) \rightarrow$ the frame mode of the fractal poetical model of the world (frames) $\rightarrow$ the integrated mode of the fractal poetical model of the world (emergent conceptual blends).

The article is concentrated around the identification of the literary concepts and the basic conceptual tropes in the British poetry of the $\mathrm{XIX}-\mathrm{XXI}^{\mathrm{st}}$ centuries and the frame and the integrated modes of the fractal poetical model of the world will be represented in the next publications of the author of the article.

The deep nature of the fractal poetical model of the world is determined by it's complicated linguistic and cognitive aspects that are explained by the combination in the fractal poetical model of the world micro-segments (literary concepts), macro-segments (basic conceptual tropes), frames and the emergent conceptual blends in one fractal unity. We define the fractal poetical model of the world as the complex linguistic, cognitive and fractal construct that comprises from segments modelled according to the iterational and integrated methodology of the linguistic, the poetical, the cognitive analysises with the deployment into the fractal net of the conceptual senses filled with frames and conceptual blends.

10 Moskvichova O. A. (2015) Evoljucija metamorfozy $v$ anghlijsjkomu poetychnomu myslenni : monoghrafija. [The Evolution of Metamorphosis in the English Poetry : the Monograph]. Kherson : Ajlant. (in Ukrainian) 
In the cognitive linguistics has been proved that the fractal 'iteration' (from the Latin 'iteration' - 'to repeat') is the process of the multiple repetition of the analogous structure or the step as for the analogy with the previous repetitive operation. The fractal 'recursion' (from the Latin 'recursio' - 'the returning') - the process of the repetition according to the certain algorithm or the formula when the starting cycle is the result of the previous cycle. The fractal self-similarity is the fractal peculiarity of the whole fractal system in which the structural organization of an element is repeated completely or partially according to the structure of other elements of the whole fractal system ${ }^{11}$.

In the article we propose the fractal modelling of the fractal poetical model of the world based on the computer fractal modelling the fundamental fractal of which is the Mandelbrot Fractal. But our investigation is added by the linguistic and the cognitive aspects of the fractal poetical model of the world based on the results of the scientific research on the basis of the British poetry of the XIX $-\mathrm{XXI}^{\text {st }}$ centuries from the point of the cognitive linguistics and the cognitive poetics. In such a way our investigation is multidisciplinary or the subdisciplinary combining the fractal theory in the mathematics and in the fractal geometry integrated into the sphere of the cognitive linguistics and the cognitive poetics.

We have stated that the starting point of the modelling of the fractal poetical model of the world is the literary concept or literary concepts identified by us in the British poetry of the XIX $\mathrm{XXI}^{\text {st }}$ centuries. The hierarchy of the verbalized literary concepts is congregated by us into the micro-segment of the fractal poetical model of the world. We design the micro-segment of the fractal poetical model of the world on the basis of the graphic modelling of the Mandelbrot Fractal that consists from three concentric circles. The main circle of the mentioned fractal is the main cardioid and the additional circles are the copies of the main cardioid circle. The number of additional circles may be endless (e.g., (Fig. 6)):

11 Bystrov Ja. V. (2016) Bioghrafichnyj naratyv u linghvokoghnityvnomu vymiri (na materiali anghlomovnoji prozy XX - pochatku XXI stolitj) [The Biographical Narrative in the Linguistic and the Cognitive Aspects (on the basis of the English Prose of the $X X^{\text {th }}$ - the beginning of the XXI ${ }^{\text {st }}$ Centuries] : dys. ... d-ra fil. nauk : 10.02.04 / Kyjivsjkyj nac. linghvistychnyj un-t. Kyjiv. (in Ukrainian) 


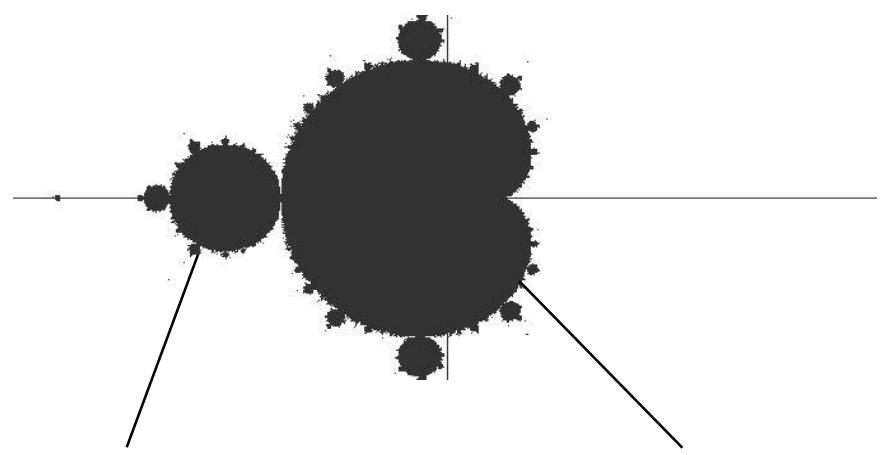

additional circles

the main cardioid circle

\section{Fig. 6. The graphic modelling and the structure of the Mandelbrot Fractal}

According to such a graphic design of the structure of the Mandelbrot Fractal we model the micro-segment of the fractal poetical model of the world that is impregnated by the identified by us literary concepts on the basis of the British poetry of the XIX $-\mathrm{XXI}^{\text {st }}$ centuries. The main cardioid circle of the micro-segment of the fractal poetical model of the world (1) is the presentive and the sensual and is impregnated by the aptly identified literary concepts in the British poetry of the XIX $-\mathrm{XXI}^{\text {st }}$ centuries. The first additional circle of the fractal micro-segment of the fractal poetical model of the world (2) is denominated by us the typology of the conceptual and the semantic approximations on the micro-level of the micro-segment and is nominated by us the imaginative and the associative circle. This circle we impregnate by the literary concepts containing the information of the associative type. The next additional circle (3) is the circle of the conceptual and the semantic deviations and is impregnated by rare literary concepts and is identified by us as the semantic circle (e.g., (Fig. 7)):

In the analogical way we design the macro-segment of the fractal poetical model of the world that is repleted by the reconstructed by us conceptual tropes (the conceptual metaphor, the conceptual metonymy, the conceptual oxymoron, the conceptual metamorphosis ${ }^{12}$ (e.g., (Fig. 8)):

12 Moskvichova O. A. (2015) Evoljucija metamorfozy $v$ anghlijsjkomu poetychnomu myslenni : monoghrafija. [The Evolution of Metamorphosis in the English Poetry : the Monograph]. Kherson : Ajlant. (in Ukrainian) 


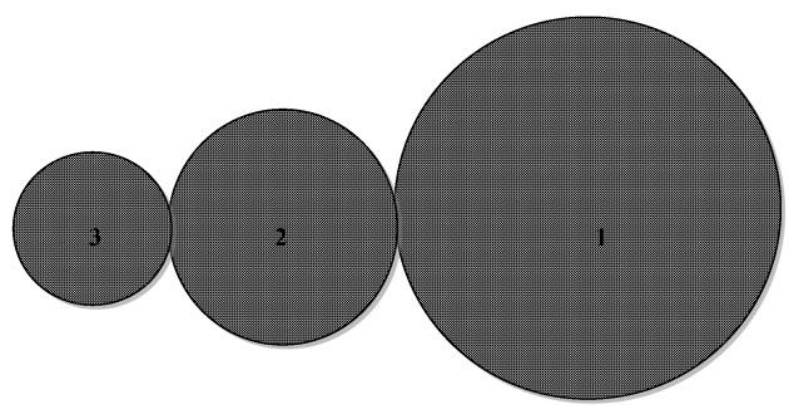

Fig. 7. The fractal modelling of the micro-segments of the fractal poetical model of the world the presentive and the sensual microsegment of the typology of the fractal iterations of the self-similar literary concepts; $\mathbf{2}$ - the conceptual and the semantic micro-segment of the typology of the conceptual and the semantic approximations; 3 - the semantic micro-segment of the typology of the conceptual and the semantic deviations)

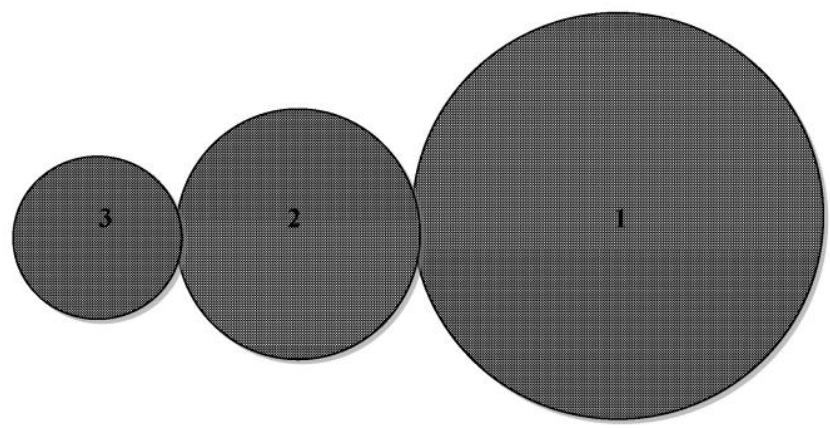

Fig. 8. The fractal modelling of the macro-segments of the fractal poetical model of the world

(1- the presentive and the sensual macro-segment of the typology of the fractal iterations of the self-similar conceptual tropes; 2 - the conceptual and the semantic macro-segment of the typology of the conceptual and the semantic approximations; 3 - the semantic macrosegment of the typology of the conceptual and the semantic deviations)

As we have been mentioned the fractal recursion is the process when the previous step of the fractal modelling is the starting point of the design of the next fractal step. The Mandelbrot Fractal in the fractal 
geometry is the starting point or the reservoir for the further fractal modelling the variety of which is identified in mathematics and the fractal geometry (e.g., (Fig. 9; Fig. 10)):

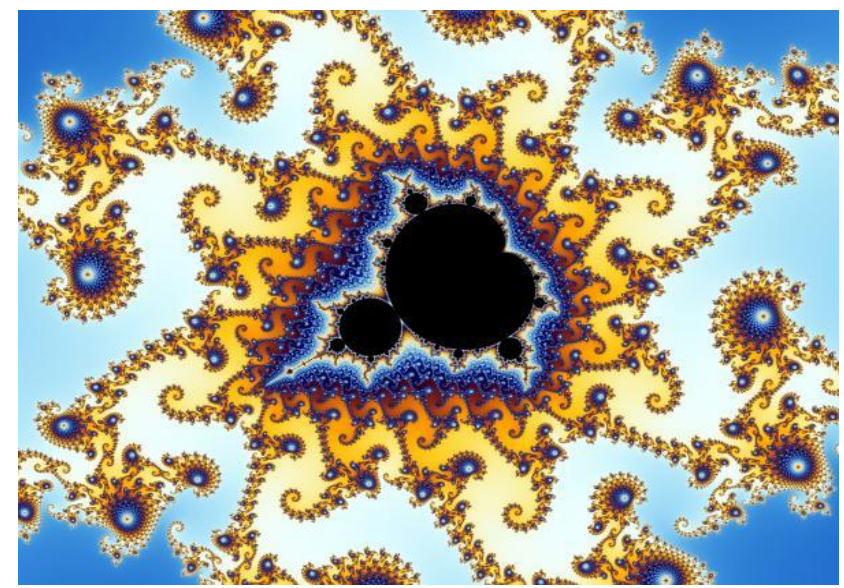

Fig. 9. The computer design of various fractals from the reservoir of the Mandelbrot Fractal

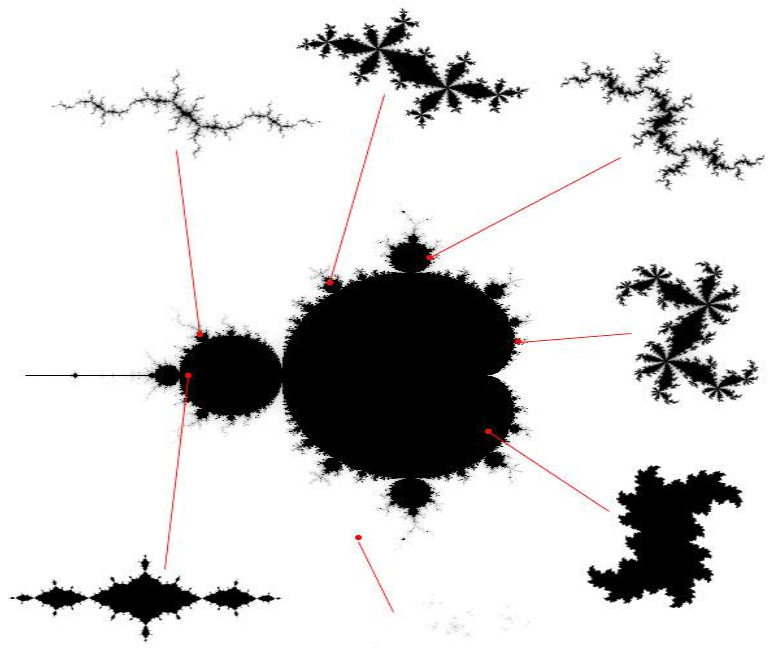

Fig. 10. The modification of various fractals from the reservoir of the Mandelbrot Fractal 
In our scientific investigation the micro-segment of the fractal poetical model of the world is transformed into the segment of the conceptual senses of the frame mode fulfilled by frames. The macrosegment of the fractal poetical model of the world is transformed into the net of the conceptual senses of the integrated mode fulfilled by emergent conceptual blends. Frames and conceptual blends are modelled according to linguistic and cognitive operations and procedures existing in the cognitive linguistics and the cognitive poetics and will be presented by us in the next articles (e.g., (Fig. 11)):

The micro-segment

of the fractal poetical

model of the world

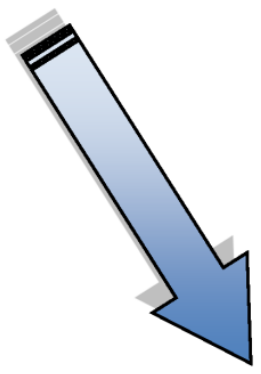

The frame mode

of the fractal poetical model of the world (frames) world (conceptual blends)
The macro-segment of the fractal poetical model of the world

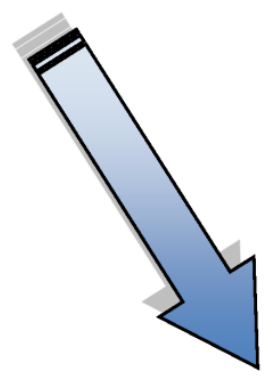

The integrated mode of the fractal poetical model of the

\section{Fig. 11. The transformation of micro- and macro-segments of the fractal poetical model of the world into integrated modes}

Graphically integrated modes will be designed by us as various types of fractals. Thus frames will be modelled as the Fractal 'Snowflake', conceptual blends - as the Fractal 'Square' (e.g., (Fig. 12)): 

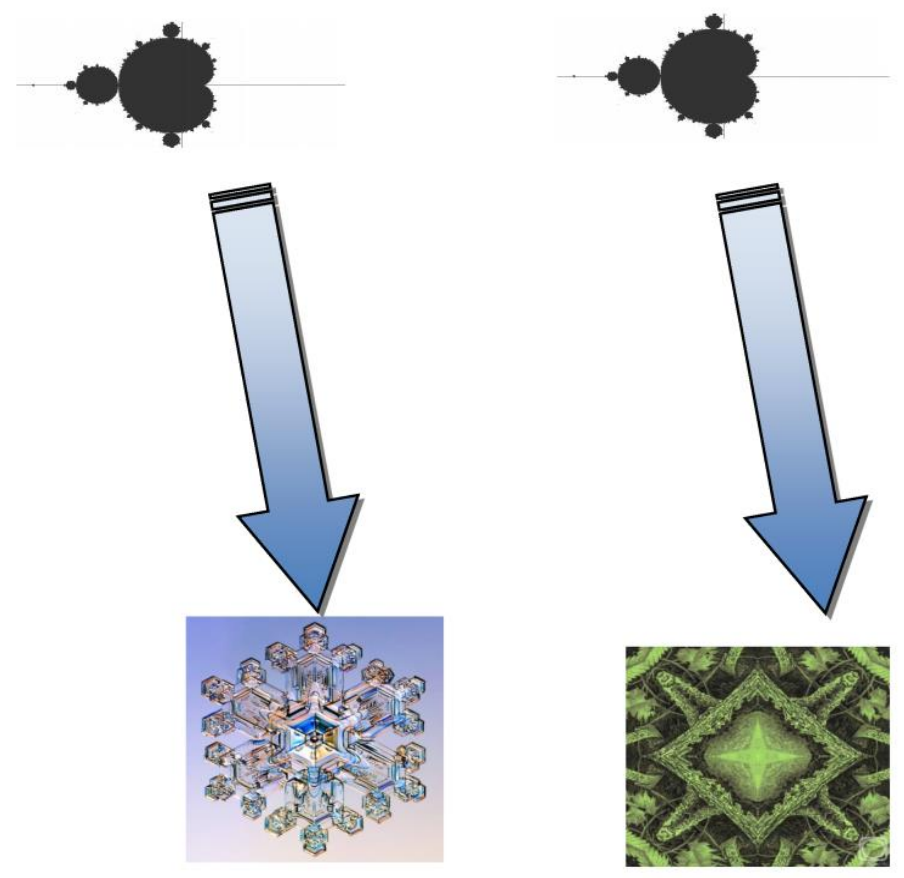

Fig. 12. The graphic transformation of micro- and macro-segments of the fractal poetical model of the world into integrated modes

The fractal iteration in the process of the modelling of the fractal poetical model of the world is characterized by us as main procedures of the identification and the reconstruction of literary concepts and conceptual tropes existing in the cognitive linguistics and in the cognitive poetics. And the whole fractal poetical model of the world, consisting from micro- and macrosegments, integrated frames and conceptual blends modes will be graphically modelled as the Dragon Fractal of HarterHeighway or the Fractal Julia and will be presented in the next scientific publications of the author (e.g., (Fig. 13)):

In the result of the investigation of the realization of the designed fractal poetical model of the world in the British poetry of the XIX $\mathrm{XXI}^{\text {st }}$ centuries we propose the summarizing results that form the basis for the construction of the micro- and the macro-segments of the fractal poetical model of the world. The material of the scientific doctoral research of the author in the doctoral dissertation on the title "The fractal 
poetical model of the world in the linguistic and the cognitive survey (on the material of the British poetry of the XIX $-\mathrm{XXI}^{\text {st }}$ centuries) includes the British poetry of the mentioned centuries in the total amount of 3628 poetical texts (4832 pages). From the analyzed poetry the author of the article has chosen the brightest examples (490 poetical texts (267 pages)). The results of the investigation are illustrated by the author in the doctoral dissertation on the basis of 230 poetical texts. In the article we represent the summarizing results in tables because the whole amount of the poetical texts analyzed in the dissertation comprises 93 pages and can't be illustrated in the article.

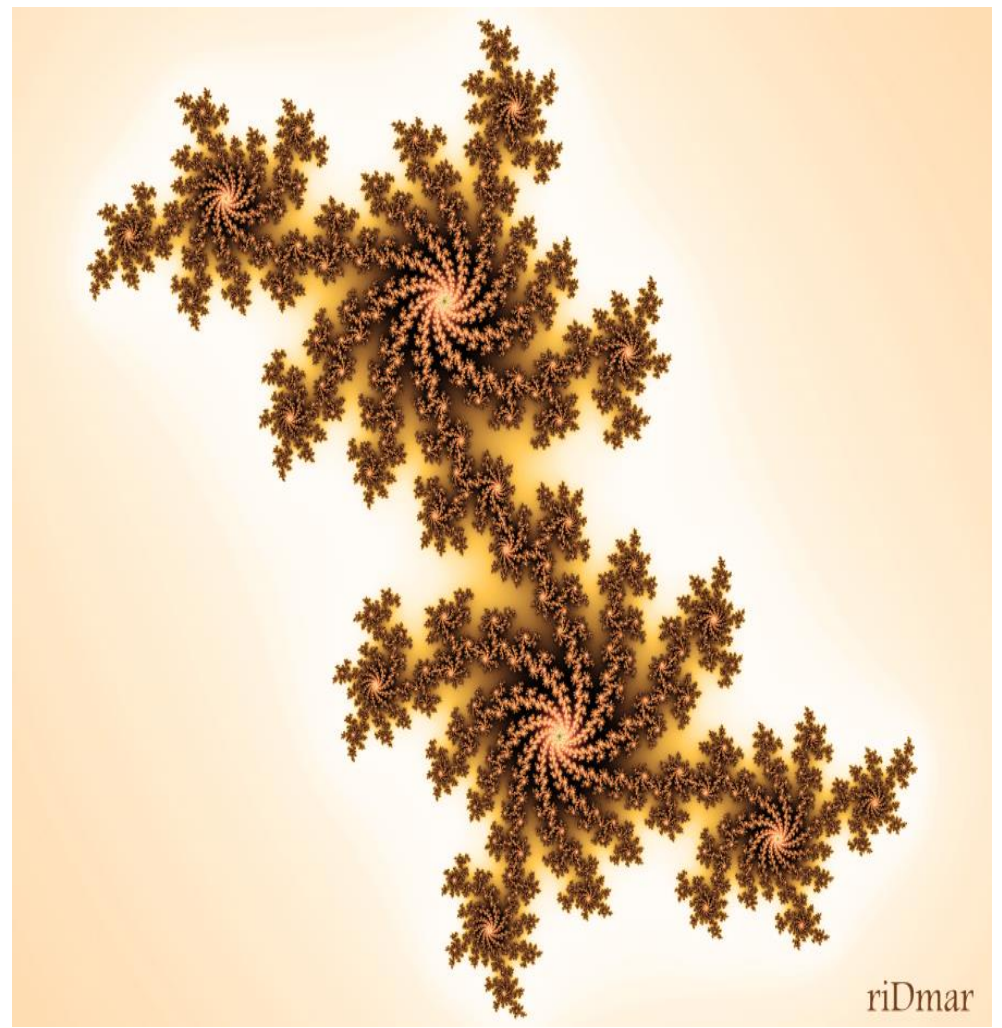

Fig. 13. The Dragon Fractal of Harter-Heighway or the Fractal Julia

As we have mentioned the microsegment of the fractal poetical model of the world is represented by the identified literary concepts in the 
British poetry of the XIX $-\mathrm{XXI}^{\text {st }}$ centuries. We have stated that microand macrosegments of the fractal poetical model of the world are designed by us on the basis of the Mandelbrot Fractal. Both micro- and macrosegments consist of tree circles, such as:

- the first main cardioid circle (the presentive and the sensual) - (1);

- the second additional circle (the conceptual and the semantic approximations) - (2);

- the third additional circle (the semantic deviations) - (3).

Graphically both micro- and macro segments we design according to the model of the Mandelbrot Fractal (e.g., (Fig. 14)):

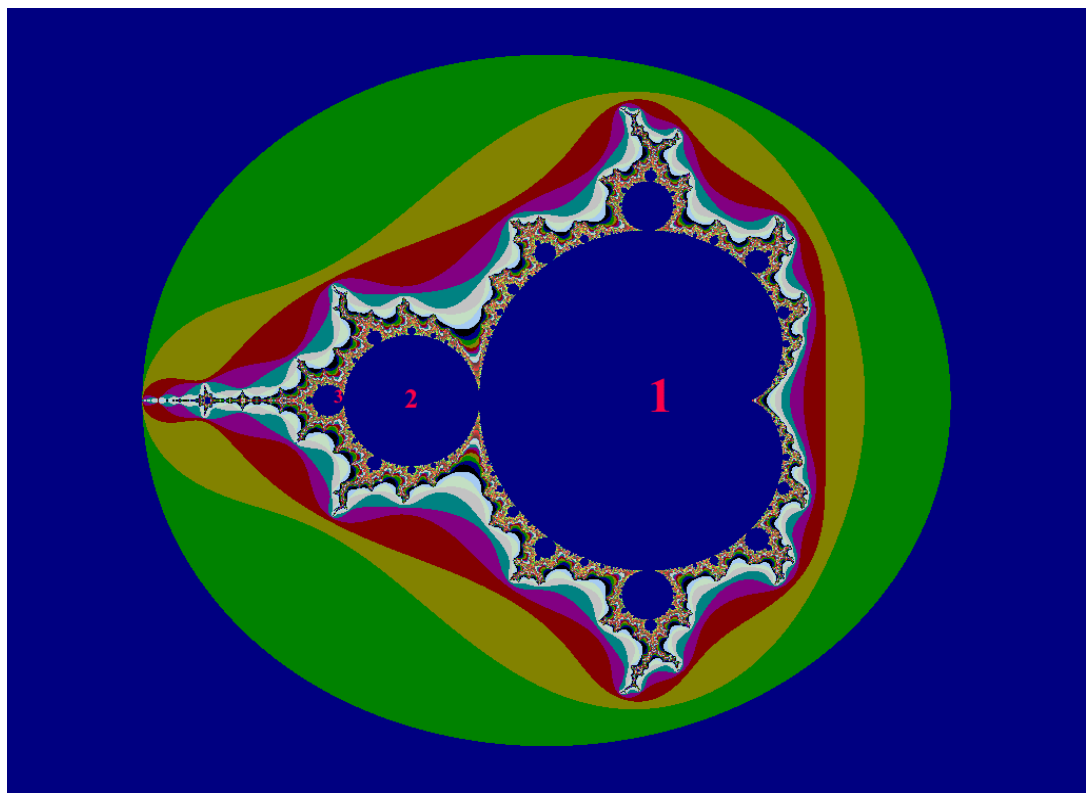

Fig. 14. The graphic design of micro- and macrosegments of the fractal poetical model of the world

The hierarchy of the literary concepts identified in the British poetry of the romantic period that fill the first main circle of the microsegment of the fractal poetical model of the world are presented in the following table (numbers $1-4$ ). The second additional circle is filled by the literary concepts (numbers $5-34$ ). The third additional circle is filled by the literary concepts (numbers 35 - 79) (Table 1): 
Table 1

Literary concepts identified in the British poetical texts of the romantic period

\begin{tabular}{|c|l|c|}
\hline \multicolumn{2}{|c|}{ The hierarchy of the literary concepts } & $\begin{array}{c}\text { The total amount of } \\
\text { the realization }(\%)\end{array}$ \\
\hline $\mathbf{1}$ & \multicolumn{1}{|c|}{$\mathbf{3}$} \\
\hline 1. & LIFE & $45(15 \%)$ \\
\hline 2. & DEATH & $40(13 \%)$ \\
\hline 3. & LOVE & $32(10 \%)$ \\
\hline 4. & PERSON / PERSONALITY & $22(7 \%)$ \\
\hline 5. & GOD & $16(5 \%)$ \\
\hline 6. & TIME & $16(5 \%)$ \\
\hline 7. & NATURE & $10(3 \%)$ \\
\hline 8. & JOY & $7(2 \%)$ \\
\hline 9. & REVIVAL & $6(1,9 \%)$ \\
\hline 10. & HAPPINESS & $5(1,6 \%)$ \\
\hline 11. & HOPE & $5(1,6 \%)$ \\
\hline 12. & FREEDOM & $5(1,6 \%)$ \\
\hline 13. & DREAM & $4(1,3 \%)$ \\
\hline 14. & FRIEND & $3(0,9 \%)$ \\
\hline 15. & SLEEP & $3(0,9 \%)$ \\
\hline 16. & SOUL & $3(0,9 \%)$ \\
\hline 17. & WOMAN & $3(0,9 \%)$ \\
\hline 18. & HEAVEN & $3(0,9 \%)$ \\
\hline 19. & IDENTITY & $2(0,6 \%)$ \\
\hline 20. & INHUMANITY & $2(0,6 \%)$ \\
\hline 21. & FATE & $2(0,6 \%)$ \\
\hline 22. & PLEASURE & $2(0,6 \%)$ \\
\hline 23. & AGE & $2(0,6 \%)$ \\
\hline 24. & SELF & $2(0,6 \%)$ \\
\hline 25. & DAY & $2(0,6 \%)$ \\
\hline 26. & JOURNEY & $2(0,6 \%)$ \\
\hline 27. & FRIENDSHIP & $2(0,6 \%)$ \\
\hline 28. & MIRACLE & $2(0,6 \%)$ \\
\hline 29. & BETRAYAL & $2(0,6 \%)$ \\
\hline 30. & FAME & $2(0,6 \%)$ \\
\hline 31. & MYTHOLOGY & $2(0,6 \%)$ \\
\hline 32. & WORLD & \\
\hline & & $2 \%)$ \\
\hline
\end{tabular}


Continuation of table 1

\begin{tabular}{|c|c|c|}
\hline $\mathbf{1}$ & 2 & 3 \\
\hline 33. & INSPIRATION & $2(0,6 \%)$ \\
\hline 34. & PEOPLE & $2(0,6 \%)$ \\
\hline 35. & COLOUR & $1(0,3 \%)$ \\
\hline 36. & MOTHER & $1(0,3 \%)$ \\
\hline 37. & CHILD & $1(0,3 \%)$ \\
\hline 38. & HEART & $1(0,3 \%)$ \\
\hline 39. & THOUGHT & $1(0,3 \%)$ \\
\hline 40. & ENGLAND & $1(0,3 \%)$ \\
\hline 41. & GRIEF & $1(0,3 \%)$ \\
\hline 42. & TRINITY & $1(0,3 \%)$ \\
\hline 43. & PAIN & $1(0,3 \%)$ \\
\hline 44. & WILINESS & $1(0,3 \%)$ \\
\hline 45. & VALUE & $1(0,3 \%)$ \\
\hline 46. & HOLINESS & $1(0,3 \%)$ \\
\hline 47. & HEALTH & $1(0,3 \%)$ \\
\hline 48. & CONTAINER & $1(0,3 \%)$ \\
\hline 49. & CREATION & $1(0,3 \%)$ \\
\hline 50. & SIN & $1(0,3 \%)$ \\
\hline 51. & DOG & $1(0,3 \%)$ \\
\hline 52. & RESURRECTION & $1(0,3 \%)$ \\
\hline 53. & IMMORTALITY & $1(0,3 \%)$ \\
\hline 54. & POWER & $1(0,3 \%)$ \\
\hline 55. & POISON & $1(0,3 \%)$ \\
\hline 56. & MUTABILITY & $1(0,3 \%)$ \\
\hline 57. & ART & $1(0,3 \%)$ \\
\hline 58. & CITY & $1(0,3 \%)$ \\
\hline 59. & DECORATION & $1(0,3 \%)$ \\
\hline 60. & NIGHT & $1(0,3 \%)$ \\
\hline 61. & MUSIC & $1(0,3 \%)$ \\
\hline 62. & NUMBER & $1(0,3 \%)$ \\
\hline 63. & EGO & $1(0,3 \%)$ \\
\hline 64. & MELODY & $1(0,3 \%)$ \\
\hline 65. & AMBITION & $1(0,3 \%)$ \\
\hline 66. & WORD & $1(0,3 \%)$ \\
\hline 67. & LIGHT & $1(0,3 \%)$ \\
\hline 68. & FEELINGS & $1(0,3 \%)$ \\
\hline
\end{tabular}


End of table 1

\begin{tabular}{|c|c|c|}
\hline 1 & 2 & 3 \\
\hline 69. & SILENCE & $1(0,3 \%)$ \\
\hline 70 . & MOTION & $1(0,3 \%)$ \\
\hline 71. & HUMAN BEING & $1(0,3 \%)$ \\
\hline 72. & FEAR & $1(0,3 \%)$ \\
\hline 73. & TRUTH & $1(0,3 \%)$ \\
\hline 74. & BURDEN & $1(0,3 \%)$ \\
\hline 75 . & MIND & $1(0,3 \%)$ \\
\hline 76. & WEALTH & $1(0,3 \%)$ \\
\hline 77. & PLAY & $1(0,3 \%)$ \\
\hline 78. & POETRY & $1(0,3 \%)$ \\
\hline 79. & FLOWER & $1(0,3 \%)$ \\
\hline & \multicolumn{2}{|c|}{$\begin{array}{c}\text { The total amount of the literary concepts }-305(100 \%) \text {. } \\
\text { Numbers } 1-4-139(45 \%) \text {. } \\
\text { Numbers } 5-34-121(40 \%) \text {. } \\
\text { Numbers } 35-79-45(15 \%) .\end{array}$} \\
\hline
\end{tabular}

The hierarchy of the conceptual metaphors identified in the British poetry of the romantic period that fill the first main circle of the macrosegment of the fractal poetical model of the world are presented in the following table (numbers 1-2). The second additional circle is filled by the conceptual metaphors (numbers $3-18$ ). The third additional circle is filled by the conceptual metaphors (numbers 19-148) (Table 2):

Table 2

Conceptual metaphors reconstructed in the British poetical texts of the romantic period

\begin{tabular}{|c|l|c|}
\hline \multicolumn{2}{|c|}{$\begin{array}{c}\text { The hierarchy of the conceptual } \\
\text { metaphors }\end{array}$} & $\begin{array}{c}\text { The total amount of the } \\
\text { realization }(\%)\end{array}$ \\
\hline $\mathbf{1}$ & \multicolumn{1}{|c|}{$\mathbf{2}$} & $\mathbf{3}$ \\
\hline 1. & LIFE IS A JOURNEY & $7(4 \%)$ \\
\hline 2. & GOD IS UP & $6(3 \%)$ \\
\hline 3 & LIFE IS A RACE & $5(2,7 \%)$ \\
\hline 4. & DEATH IS SLEEP & $4(2 \%)$ \\
\hline 5. & LIFE IS A DREAM & $3(1,6 \%)$ \\
\hline 6. & TIME IS A MOTION & $3(1,6 \%)$ \\
\hline 7. & $\begin{array}{l}\text { LOVE IS A HUMAN BEING } \\
\text { (A PERSON) }\end{array}$ & $3(1,6 \%)$ \\
\hline
\end{tabular}


Continuation of table 2

\begin{tabular}{|c|c|c|}
\hline 1 & 2 & $\mathbf{3}$ \\
\hline 8. & LIFE IS WOE & $2(1 \%)$ \\
\hline 9. & GOD IS LOVE & $2(1 \%)$ \\
\hline 10. & $\begin{array}{l}\text { DEATH IS THE END OF A } \\
\text { JOURNEY }\end{array}$ & $2(1 \%)$ \\
\hline 11. & LOVE IS SLEEP & $2(1 \%)$ \\
\hline 12. & BEAUTY IS A LIVING BEING & $2(1 \%)$ \\
\hline 13. & LOVE IS THE POWER & $2(1 \%)$ \\
\hline 14. & NATURE IS A TEACHER & $2(1 \%)$ \\
\hline 15. & LIFE IS A CHANGE & $2(1 \%)$ \\
\hline 16. & DEATH IS LOVE & $2(1 \%)$ \\
\hline 17. & $\begin{array}{lcr}\text { LIFE IS A } & \text { JOURNEY } \\
\text { THROUGH TIME } & \\
\end{array}$ & $2(1 \%)$ \\
\hline 18. & LIFE IS STRUGGLE & $2(1 \%)$ \\
\hline 19. & PEOPLE ARE ANIMALS & $1(0,5 \%)$ \\
\hline 20. & DEATH IS THE FRIEND & $1(0,5 \%)$ \\
\hline 21. & $\begin{array}{l}\text { THE FATE OF A PERSON IS } \\
\text { THE RURAL SHADE }\end{array}$ & $1(0,5 \%)$ \\
\hline 22. & $\begin{array}{l}\text { THE FATE OF A PERSON IS } \\
\text { THE OCEAN }\end{array}$ & $1(0,5 \%)$ \\
\hline 23. & LIFE IS A PLEASURE & $1(0,5 \%)$ \\
\hline 24. & PEOPLE ARE PLANTS & $1(0,5 \%)$ \\
\hline 25. & A PERSON IS A STRANGER & $1(0,5 \%)$ \\
\hline 26. & LIFE IS DEATH & $1(0,5 \%)$ \\
\hline 27. & DEATH IS REVIVAL & $1(0,5 \%)$ \\
\hline 28. & EMOTIONS ARE NATURE & $1(0,5 \%)$ \\
\hline 29. & $\begin{array}{l}\text { LIFE IS A DAY, HAPPINESS IS } \\
\text { A NAME (A PERSON OR A } \\
\text { WORD) }\end{array}$ & $1(0,5 \%)$ \\
\hline 30. & $\begin{array}{lcr}\text { AMBITION IS A } & \text { METEOR- } \\
\text { GLEAM (A LIGHT) } & \\
\end{array}$ & $1(0,5 \%)$ \\
\hline 31. & FAME IS A DREAM & $1(0,5 \%)$ \\
\hline 32. & LOVE IS A DREAM & $1(0,5 \%)$ \\
\hline 33. & JOY IS LIFE & $1(0,5 \%)$ \\
\hline 34. & PLEASURE IS LIFE & $1(0,5 \%)$ \\
\hline 35. & EMOTIONS ARE LIFE & $1(0,5 \%)$ \\
\hline 36. & LIFE IS A BURDEN & $1(0,5 \%)$ \\
\hline 37. & TIME IS MOVEMENT & $1(0,5 \%)$ \\
\hline
\end{tabular}


Continuation of table 2

\begin{tabular}{|c|c|c|}
\hline 1 & 2 & 3 \\
\hline 38. & LOVE IS TRUE & $1(0,5 \%)$ \\
\hline 39. & MIND IS WEALTH & $1(0,5 \%)$ \\
\hline 40. & FRIENDSHIP IS A GIFT & $1(0,5 \%)$ \\
\hline 41. & LIFE IS A MORNING & $1(0,5 \%)$ \\
\hline 42. & LIFE IS A PLAY & $1(0,5 \%)$ \\
\hline 43. & GOD IS THE HEALER & $1(0,5 \%)$ \\
\hline 44. & 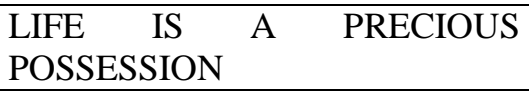 & $1(0,5 \%)$ \\
\hline 45. & TIME IS A DESTROYER & $1(0,5 \%)$ \\
\hline 46. & A PERSON IS AN ANGEL & $1(0,5 \%)$ \\
\hline 47. & PERSON IS A CONTAINER & $1(0,5 \%)$ \\
\hline 48. & LOVE IS IMMORTAL & $1(0,5 \%)$ \\
\hline 49. & FATE IS DARK & $1(0,5 \%)$ \\
\hline 50. & PEOPLE ARE CLOUDS & $1(0,5 \%)$ \\
\hline 51. & DREAM IS THE POWER & $1(0,5 \%)$ \\
\hline 52. & SLEEP IS POISON & $1(0,5 \%)$ \\
\hline 53. & MUTABILITY IS JOY & $1(0,5 \%)$ \\
\hline 54. & MUTABILITY IS SORROW & $1(0,5 \%)$ \\
\hline 55. & DEATH IS MILD & $1(0,5 \%)$ \\
\hline 56. & A CITY IS THE CRADLE & $1(0,5 \%)$ \\
\hline 57. & A CITY IS THE GRAVE & $1(0,5 \%)$ \\
\hline 58. & DEATH IS NIGHT & $1(0,5 \%)$ \\
\hline 59. & MUSIC IS THE LIVING BEING & $1(0,5 \%)$ \\
\hline 60. & LIFE IS UP & $1(0,5 \%)$ \\
\hline 61. & LIFE IS A RAINBOW & $1(0,5 \%)$ \\
\hline 62. & GOD IS THE CHILD & $1(0,5 \%)$ \\
\hline 63. & LIFE IS PIETY & $1(0,5 \%)$ \\
\hline 64. & A BRITON IS A SUBJECT & $1(0,5 \%)$ \\
\hline 65. & $\begin{array}{l}\text { PEOPLE ARE CREATURES OF } \\
\text { A WINTER'S DAY }\end{array}$ & $1(0,5 \%)$ \\
\hline 66. & LOVE IS A TEACHER & $1(0,5 \%)$ \\
\hline 67. & LOVE IS DEATH & $1(0,5 \%)$ \\
\hline 65. & LOVE IS GRAVE & $1(0,5 \%)$ \\
\hline 68. & LOVE IS PAIN & $1(0,5 \%)$ \\
\hline 69. & A PERSON IS A STATUE & $1(0,5 \%)$ \\
\hline 70. & LOVE IS A FOUNTAIN & $1(0,5 \%)$ \\
\hline
\end{tabular}


Continuation of table 2

\begin{tabular}{|c|c|c|}
\hline 1 & $\mathbf{2}$ & $\mathbf{3}$ \\
\hline 71. & NATURE IS THE CREATOR & $1(0,5 \%)$ \\
\hline 72. & $\begin{array}{llll}\text { THE LIFE OF } & \text { A } & \text { HUMAN } \\
\text { BEING IS A DAY } & & \\
\end{array}$ & $1(0,5 \%)$ \\
\hline 73. & THE LIFE IS THE MYSTERY & $1(0,5 \%)$ \\
\hline 74. & $\begin{array}{l}\text { A WOMAN IS A PHANTOM OF } \\
\text { DELIGHT / A LOVELY } \\
\text { APPARITITION / A MOMENT'S } \\
\text { ORNAMENT / A DANCING } \\
\text { SHAPE / AN IMAGE / A } \\
\text { CREATURE / A BEING / A } \\
\text { TRAVELLER BETWEEN LIFE } \\
\text { AND DEATH / AN ANGELIC } \\
\text { LIGHT }\end{array}$ & $1(0,5 \%)$ \\
\hline 75. & DEATH IS REST & $1(0,5 \%)$ \\
\hline 76. & HEART IS A CONTAINER & $1(0,5 \%)$ \\
\hline 77. & SOUL IS THE DARKNESS & $1(0,5 \%)$ \\
\hline 78. & LIFE IS SEA & $1(0,5 \%)$ \\
\hline 79. & TIME IS A LIVING BEING & $1(0,5 \%)$ \\
\hline 80. & HOPE IS A LIVING BEING & $1(0,5 \%)$ \\
\hline 81. & TIME IS HOPE & $1(0,5 \%)$ \\
\hline 82. & $\begin{array}{l}\text { TEARS ARE THE LIGHT OF } \\
\text { GLADNESS }\end{array}$ & $1(0,5 \%)$ \\
\hline 83. & WORDS ARE GOLD & $1(0,5 \%)$ \\
\hline 84. & A PERSON IS A NIGHTINGALE & $1(0,5 \%)$ \\
\hline 85. & JOY IS THE MASK & $1(0,5 \%)$ \\
\hline 86. & LIFE IS A CAVERN & $1(0,5 \%)$ \\
\hline 87. & LIFE IS A GLIMMER & $1(0,5 \%)$ \\
\hline 88. & A PERSON IS THE SPIRIT & $1(0,5 \%)$ \\
\hline 89. & A PERSON IS A SOUL & $1(0,5 \%)$ \\
\hline 90. & $\begin{array}{l}\text { HEART IS A CONTAINER } \\
\text { FULL OF SWEET IMAGES }\end{array}$ & $1(0,5 \%)$ \\
\hline 91. & LIFE IS A GAME & $1(0,5 \%)$ \\
\hline 92. & LIFE IS A VALUE & $1(0,5 \%)$ \\
\hline 93. & THE WORLD IS THE WHEEL & $1(0,5 \%)$ \\
\hline 94. & FREEDOM IS UP & $1(0,5 \%)$ \\
\hline 95. & HEAVEN IS UP & $1(0,5 \%)$ \\
\hline 96. & LIFE IS A DAY & $1(0,5 \%)$ \\
\hline
\end{tabular}


Continuation of table 2

\begin{tabular}{|c|c|c|}
\hline 1 & 2 & 3 \\
\hline 97. & DEATH IS DOWN & $1(0,5 \%)$ \\
\hline 98. & $\begin{array}{l}\text { LIFE IS A FLOWER / LIFE IS } \\
\text { A ROSE }\end{array}$ & $1(0,5 \%)$ \\
\hline 99. & LIFE IS AN ILLUSION & $1(0,5 \%)$ \\
\hline 100. & SOUL IS A SHIP & $1(0,5 \%)$ \\
\hline 101. & $\begin{array}{l}\text { A WOMAN (A PERSON) IS A } \\
\text { LIGHT }\end{array}$ & $1(0,5 \%)$ \\
\hline 102. & GOD IS A LIGHT & $1(0,5 \%)$ \\
\hline 103. & $\begin{array}{lccc}\text { LIFE } & \text { IS } & \text { A } & \text { JOURNEY } \\
\text { THRUOGH TIME } & \end{array}$ & $1(0,5 \%)$ \\
\hline 104. & $\begin{array}{llll}\text { LOVE } & \text { IS } & \text { A } & \text { MAGNETIC } \\
\text { FORSE } & & & \end{array}$ & $1(0,5 \%)$ \\
\hline 105. & DEATH IS LIGHT & $1(0,5 \%)$ \\
\hline 106. & HAPPINESS IS ENGLAND & $1(0,5 \%)$ \\
\hline 107. & DEATH IS PAIN & $1(0,5 \%)$ \\
\hline 108. & LIFE IS TRINITY & $1(0,5 \%)$ \\
\hline 109. & JOY IS LIGHT & $1(0,5 \%)$ \\
\hline 110. & LIFE IS A FROST & $1(0,5 \%)$ \\
\hline 111. & LOVE IS LIGHT & $1(0,5 \%)$ \\
\hline 112. & LOVE IS A TOMB & $1(0,5 \%)$ \\
\hline 113. & JOY IS HAPPINESS & $1(0,5 \%)$ \\
\hline 114. & GOD IS LIGHT & $1(0,5 \%)$ \\
\hline 115. & $\begin{array}{l}\text { DREAMS ARE STREAMS OF } \\
\text { SHADOWS }\end{array}$ & $1(0,5 \%)$ \\
\hline 116. & LOVE IS BONDAGE & $1(0,5 \%)$ \\
\hline 117. & LOVE IS A HEAVEN & $1(0,5 \%)$ \\
\hline 118. & LOVE IS A HELL & $1(0,5 \%)$ \\
\hline 119. & LOVE IS A CRIME & $1(0,5 \%)$ \\
\hline 120. & DEATH IS THE GARMENT & $1(0,5 \%)$ \\
\hline 121. & HAPPINESS IS WOE & $1(0,5 \%)$ \\
\hline 122. & HEAVEN IS MISERY & $1(0,5 \%)$ \\
\hline 123. & LOVE IS A WIND & $1(0,5 \%)$ \\
\hline 124. & DEATH IS THE BLOSSOM & $1(0,5 \%)$ \\
\hline 125. & LOVE IS A SIN & $1(0,5 \%)$ \\
\hline 126. & $\begin{array}{llll}\text { DEATH } & \text { IS } & \text { THE } & \text { LIVING } \\
\text { BEING } & & & \\
\end{array}$ & $1(0,5 \%)$ \\
\hline
\end{tabular}


End of table 2

\begin{tabular}{|c|c|c|}
\hline 1 & 2 & $\mathbf{3}$ \\
\hline 127. & LOVE IS DESIRE & $1(0,5 \%)$ \\
\hline 128. & LOVE IS A FLAME & $1(0,5 \%)$ \\
\hline 129. & $\begin{array}{l}\text { THE WORLD IS A } \\
\text { CONTAINER }\end{array}$ & $1(0,5 \%)$ \\
\hline 130. & HOPE IS A DREAM & $1(0,5 \%)$ \\
\hline 131. & LOVE IS A UNITY & $1(0,5 \%)$ \\
\hline 132. & LOVE IS A GRIEF & $1(0,5 \%)$ \\
\hline 133. & TIME IS THE RIVER & $(0,5 \%) 1$ \\
\hline 134. & LIFE IS A CYCLE & $1(0,5 \%)$ \\
\hline 135. & LOVE IS A CONTAINER & $1(0,5 \%)$ \\
\hline 136. & DREAMS ARE THE SALE & $1(0,5 \%)$ \\
\hline 137. & LIFE IS DEATH & $1(0,5 \%)$ \\
\hline 138. & DREAM IS A PRIZE & $1(0,5 \%)$ \\
\hline 139. & JOY IS HEAVEN & $1(0,5 \%)$ \\
\hline 140. & HOPE IS LIGHT & $1(0,5 \%)$ \\
\hline 141. & DEATH IS COLD & $1(0,5 \%)$ \\
\hline 142. & TIME IS A SEASON & $1(0,5 \%)$ \\
\hline 143. & HOPE IS A COMFORTER & $1(0,5 \%)$ \\
\hline 144. & TIME IS DEATH & $1(0,5 \%)$ \\
\hline 145. & LIFE IS A SEASON & $1(0,5 \%)$ \\
\hline 146. & LOVE IS A BIRD & $1(0,5 \%)$ \\
\hline 147. & $\begin{array}{l}\text { LOVE IS THE CROWN OF } \\
\text { THORNS }\end{array}$ & $1(0,5 \%)$ \\
\hline 148. & LIFE IS A CURSE & $1(0,5 \%)$ \\
\hline \multicolumn{3}{|c|}{$\begin{array}{c}\text { The total amount of the literary concepts }-184(100 \%) \text {. } \\
\text { Numbers } 1-2-13(7 \%) . \\
\text { Numbers }-3-18(40 \%) . \\
\text { Numbers } 19-148-131(71 \%) .\end{array}$} \\
\hline
\end{tabular}

The hierarchy of the conceptual metonymies reconstructed in the British poetry of the romantic period that fill the second additional circle and are represented in the following table (Table 3): 
Table 3

Conceptual metonymies reconstructed in the British poetry of the romantic period

\begin{tabular}{|c|c|c|}
\hline \multicolumn{2}{|c|}{ The hierarchy of the conceptual metonymies } & $\begin{array}{l}\text { The total amount } \\
\text { of the realization }\end{array}$ \\
\hline 1 & 2 & 3 \\
\hline 149. & NATURE STANDS FOR A PERSON & $1(2 \%)$ \\
\hline 150. & DEATH STANDS FOR A FRIEND & $1(2 \%)$ \\
\hline 151. & THE VOICE STANDS FOR THE HARP & $1(2 \%)$ \\
\hline 152. & LIFE STANDS FOR THE DAY & $1(2 \%)$ \\
\hline 153. & WINTER STANDS FOR DEATH & $1(2 \%)$ \\
\hline 154. & SPRING STANDS FOR REVIVAL & $1(2 \%)$ \\
\hline 155. & $\begin{array}{llll}\text { LOVE STANDS FOR A HUMAN } \\
\text { BEING (A PERSON) }\end{array}$ & $1(2 \%)$ \\
\hline 156. & THE FEARS STAND FOR AGE & $1(2 \%)$ \\
\hline 157. & THE TEARS STAND FOR AGE & $1(2 \%)$ \\
\hline 158. & $\begin{array}{l}\begin{array}{l}\text { DUST STANDS FOR THE POET } \\
\text { (A PERSON) }\end{array} \\
\end{array}$ & $1(2 \%)$ \\
\hline 159. & $\begin{array}{l}\text { A MONUMENT STANDS FOR A } \\
\text { POET (A PERSON) }\end{array}$ & $1(2 \%)$ \\
\hline 160. & $\begin{array}{l}\text { A ROSEBUD (A FLOWER) STANDS } \\
\text { FOR A GIRL (A PERSON) }\end{array}$ & $1(2 \%)$ \\
\hline 161. & $\begin{array}{llll}\text { FRIENDSHIP } & \text { STANDS } & \text { FOR } & \text { THE } \\
\text { GIFT } & & & \\
\end{array}$ & $1(2 \%)$ \\
\hline 162. & $\begin{array}{l}\text { THE FRIENDSHIP'S } \quad \text { HEART } \\
\text { STANDS FOR THE DEAREST GIFT } \\
\text { OF HEAVEN or } \\
\text { FRIENDSHIP STANDS FOR THE } \\
\text { GIFT OF HEAVEN }\end{array}$ & $1(2 \%)$ \\
\hline 163. & $\begin{array}{l}\text { THE VOLUMES (OF POETRY) } \\
\text { STAND FOR THE POET'S PRAYER }\end{array}$ & $1(2 \%)$ \\
\hline 164. & $\begin{array}{l}\text { GUARDIAN AND REWARD STAND } \\
\text { FOR PRAYS (POETRY) OF THE } \\
\text { POET }\end{array}$ & $1(2 \%)$ \\
\hline 165. & $\begin{array}{l}\text { A SHADOW STANDS FOR A } \\
\text { PERSON }\end{array}$ & $1(2 \%)$ \\
\hline 166. & $\begin{array}{l}\text { A MUSE STANDS FOR A FRIEND } \\
\text { (A PERSON) }\end{array}$ & $1(2 \%)$ \\
\hline
\end{tabular}


Continuation of table 3

\begin{tabular}{|c|c|c|}
\hline 1 & 2 & 3 \\
\hline 167. & $\begin{array}{llll}\text { AN ANGEL } & \text { STANDS } & \text { FOR } & \text { A } \\
\text { PERSON } & & & \\
\end{array}$ & $1(2 \%)$ \\
\hline 168. & $\begin{array}{l}\text { THE POET'S DARLING FLAME } \\
\text { STANDS FOR A PERSON (JESSY) }\end{array}$ & $1(2 \%)$ \\
\hline 169. & A NAME STANDS FOR A PERSON & $1(2 \%)$ \\
\hline 170. & $\begin{array}{l}\text { HANDS, VOICE, LOOKS, LIPS } \\
\text { STAND FOR A PERSON }\end{array}$ & $1(2 \%)$ \\
\hline 171. & A SHADOW STANDS FOR A CHILD & $1(2 \%)$ \\
\hline 172. & $\begin{array}{l}\text { THE SPIRIT STANDS FOR A SLAVE } \\
\text { (A PERSON) }\end{array}$ & $1(2 \%)$ \\
\hline 173. & $\begin{array}{llll}\text { THE SPOT STANDS } & \text { FOR } & \text { THE } \\
\text { PILGRIM'S SOUL } & & \\
\end{array}$ & $1(2 \%)$ \\
\hline 174. & $\begin{array}{l}\text { THE RED FLOWER STANDS FOR } \\
\text { LOVE }\end{array}$ & $1(2 \%)$ \\
\hline 175. & $\begin{array}{l}\text { THE DYING GLADIATOR STANDS } \\
\text { FOR LOVE }\end{array}$ & $1(2 \%)$ \\
\hline 176. & $\begin{array}{l}\text { THE SAD FLOWER STANDS FOR } \\
\text { LOVE }\end{array}$ & $1(2 \%)$ \\
\hline 177. & $\begin{array}{l}\text { A FLOWER STANDS } \\
\text { PERSON }\end{array}$ & $1(2 \%)$ \\
\hline 178. & A SPIRIT STANDS FOR A PERSON & $1(2 \%)$ \\
\hline 179. & $\begin{array}{l}\text { THE SCULPTURE STANDS FOR } \\
\text { THE MOTHER }\end{array}$ & $1(2 \%)$ \\
\hline 180. & $\begin{array}{llll}\text { THE SPIRIT STANDS } & \text { FOR } & \text { THE } \\
\text { DEAD CHILD } & & & \\
\end{array}$ & $1(2 \%)$ \\
\hline 181. & $\begin{array}{l}\text { THE HUMAN SOUL STANDS FOR } \\
\text { THE MAN }\end{array}$ & $1(2 \%)$ \\
\hline 182. & $\begin{array}{l}\begin{array}{l}\text { THE HEART STANDS FOR THE } \\
\text { MAN }\end{array} \\
\end{array}$ & $1(2 \%)$ \\
\hline 183. & $\begin{array}{l}\text { A NIGHTINGALE STANDS FOR } \\
\text { THE PERSON }\end{array}$ & $1(2 \%)$ \\
\hline 184. & $\begin{array}{l}\text { THE OAK STANDS FOR THE } \\
\text { GRAVE / FOR THE MONUMENT }\end{array}$ & $1(2 \%)$ \\
\hline 185. & THE VOICE STANDS FOR GOD & $1(2 \%)$ \\
\hline 186. & $\begin{array}{l}\text { THE FLOWER STANDS FOR THE } \\
\text { THOUGHT }\end{array}$ & $1(2 \%)$ \\
\hline 187. & BEES STAND FOR THE THOUGHTS & $1(2 \%)$ \\
\hline
\end{tabular}


End of table 3

\begin{tabular}{|c|l|c|}
\hline $\mathbf{1}$ & \multicolumn{1}{|c|}{$\mathbf{2}$} & $\mathbf{3}$ \\
\hline 188. & $\begin{array}{l}\text { A FLOWER STANDS FOR A } \\
\text { WOMAN }\end{array}$ & $1(2 \%)$ \\
\hline 189. & $\begin{array}{l}\text { A LITTLE BLACK THING STANDS } \\
\text { FOR THE BOY }\end{array}$ & $1(2 \%)$ \\
\hline 190. & $\begin{array}{l}\text { AN ANGEL STANDS FOR A } \\
\text { WOMAN }\end{array}$ & $1(2 \%)$ \\
\hline 191. & $\begin{array}{l}\text { THE IMMORTAL SPIRIT STANDS } \\
\text { FOR A PERSON (SHAKESPEARE) }\end{array}$ & $1(2 \%)$ \\
\hline 192. & $\begin{array}{l}\text { A PALE GHOST STANDS FOR THE } \\
\text { PERSON (A POET) }\end{array}$ & $1(2 \%)$ \\
\hline 193. & $\begin{array}{l}\text { VOICE STANDS FOR THE PERSON } \\
\text { A POET) }\end{array}$ & $1(2 \%)$ \\
\hline 194. & $\begin{array}{l}\text { THE FLOWER (THE ROSE) STANDS } \\
\text { FOR THE PERSON (A GIRL) }\end{array}$ & $1(2 \%)$ \\
\hline 195. & $\begin{array}{l}\text { THE BIRD (THE NIGHTINGALE) } \\
\text { STANDS FOR THE PERSON (A } \\
\text { MAN) }\end{array}$ & $1(2 \%)$ \\
\hline 196. & A GHOST STANDS FOR THE BOY & $1(2 \%)$ \\
\hline 197. & $\begin{array}{l}\text { A SAINT / AN ANGEL STAND FOR } \\
\text { A GIRL }\end{array}$ & $1(2 \%)$ \\
\hline 198. & A FACE STANDS FOR A PERSON & $1(2 \%)$ \\
\hline 199. & $\begin{array}{l}\text { SEVEN OR FIVE STAND FOR } \\
\text { SISTERS AND BROTHERS }\end{array}$ & $1(2 \%)$ \\
\hline & The total amount of the conceprual metonymies - 51. \\
\hline
\end{tabular}

The hierarchy of the conceptual metamorphosises (Москвичова 2015) reconstructed in the British poetry of the romantic period that fill the first main circle of the macrosegment of the fractal poetical model of the world are presented in the following table (number 200). The second additional circle is filled by the conceptual metaphors (numbers 201 202). The third additional circle is filled by the conceptual metaphors (numbers 203-223) (Table 4): 
Table 4

Conceptual metamorphosises reconstructed in the British poetry of the romantic period

\begin{tabular}{|c|c|c|}
\hline \multicolumn{2}{|r|}{$\begin{array}{c}\text { The hierarchy of the conceptual } \\
\text { metamorphosises }\end{array}$} & $\begin{array}{l}\text { The total amount of } \\
\text { the realization }(\%)\end{array}$ \\
\hline 1 & 2 & $\mathbf{3}$ \\
\hline 200. & $\begin{array}{l}\text { AN ALIVE PERSON TURNS INTO } \\
\text { A DEAD PERSON } \\
\text { DEATH } \\
\text { METAMORPHOSIS }\end{array}$ & $11(30 \%)$ \\
\hline 201. & $\begin{array}{l}\text { A YOUNG PERSON TURNS INTO } \\
\text { AN OLD PERSON } \\
\text { TIME CAUSES METAMORPHOSIS }\end{array}$ & $3(8 \%)$ \\
\hline 202. & $\begin{array}{l}\text { A PERSON IN LOVE TURNS INTO } \\
\text { A LONELY PERSON } \\
\text { LOVE } \\
\text { METAMORPHOSIS } \\
\end{array}$ & $2(5 \%)$ \\
\hline 203. & $\begin{array}{l}\text { AUTUMN TURNS INTO WINTER } \\
\text { NOVEMBER } \\
\text { METAMORPHOSIS OF AUTUMN } \\
\text { INTO WINTER }\end{array}$ & $1(3 \%)$ \\
\hline 204. & $\begin{array}{l}\text { PEOPLE TURN INTO MOURNING } \\
\text { PEOPLE } \\
\text { MAN'S INHUMANITY CAUSES } \\
\text { PEOPLE TO MOURN }\end{array}$ & $1(3 \%)$ \\
\hline 205. & $\begin{array}{l}\text { A PERSON TURNS INTO A } \\
\text { MOURNING PERSON } \\
\text { THE MAN HAS THE POWER AND } \\
\text { THE WILL TO CHANGE A MAN } \\
\text { INTO A MOURNING FELLOW }\end{array}$ & $1(3 \%)$ \\
\hline 206. & $\begin{array}{l}\text { WRETCHEDNESS OR VICE TURN } \\
\text { INTO RUIN } \\
\text { HEART } \\
\text { METAMORPHOSIS }\end{array}$ & $1(3 \%)$ \\
\hline 207. & $\begin{array}{l}\text { A DEAD PERSON TURNS INTO } \\
\text { AN ALIVE PERSON } \\
\text { A CHARM ON EARTH CAUSES } \\
\text { METAMORPHOSIS }\end{array}$ & $1(3 \%)$ \\
\hline
\end{tabular}


Continuation of table 4

\begin{tabular}{|c|c|c|}
\hline 1 & 2 & 3 \\
\hline 208. & $\begin{array}{l}\text { A DEAD PERSON TURNS INTO } \\
\text { AN ALIVE PERSON } \\
\text { ONE SERAPH'S } \\
\text { METAMORPHOSIS }\end{array}$ & $1(3 \%)$ \\
\hline 209. & $\begin{array}{l}\text { AN ILL PERSON TURNS INTO A } \\
\text { RECOVERED PERSON } \\
\text { A P PERSON } \\
\text { METAMORPHOSIS }\end{array}$ & $1(3 \%)$ \\
\hline 210. & $\begin{array}{l}\text { THE ROSY WINE BRINGS THE } \\
\text { DARLING FLAME (INSPIRATION) } \\
\text { TO THE POET } \\
\text { THE ROSY WINE CAUSES } \\
\text { METAMORPHOSIS }\end{array}$ & $1(3 \%)$ \\
\hline 211. & $\begin{array}{l}\text { A PERSON IS TURNED INTO A } \\
\text { BLEST PERSON WITH THE } \\
\text { BROKEN HEART } \\
\text { SUSPICION OR A PERSON (he) } \\
\text { CAUSES METAMORPHOSIS } \\
\end{array}$ & $1(3 \%)$ \\
\hline 212. & $\begin{array}{l}\text { A SWINE IS TURNED INTO A } \\
\text { PERSON } \\
\begin{array}{lll} & \\
\text { A PERSON } & \text { (he) } & \text { CAUSES } \\
\text { METAMORPHOSIS } & \end{array}\end{array}$ & $1(3 \%)$ \\
\hline 213. & $\begin{array}{l}\text { A DEAD BODY (SOUL) IS } \\
\text { TURNED INTO A RESURRECTED } \\
\text { BODY (SOUL) } \\
\text { GOD (Jesus Christ or He) CAUSES } \\
\text { METAMORPHOSIS }\end{array}$ & $1(3 \%)$ \\
\hline 214. & $\begin{array}{ll}\text { SOUL IS TURNED INTO A FOUL } \\
\text { FRIEND } \\
\text { MISERY } \\
\text { METAMORPHOSIS }\end{array}$ & $1(3 \%)$ \\
\hline 215. & $\begin{array}{l}\text { THE GAZER'S SPIRIT IS TURNED } \\
\text { INTO A STONE, } \\
\text { A VAPOUR OF THE AIR IS } \\
\text { TURNED INTO A MIRROR } \\
\text { THE MEDUSA CAUSES } \\
\text { METAMORPHOSIS }\end{array}$ & $1(3 \%)$ \\
\hline
\end{tabular}


End of table 4

\begin{tabular}{|c|c|c|}
\hline 1 & 2 & 3 \\
\hline 216. & 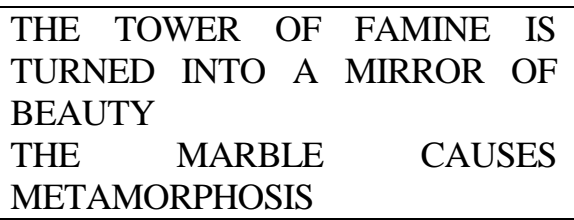 & $1(3 \%)$ \\
\hline 217. & $\begin{array}{l}\text { A PERSON IS TURNED INTO A } \\
\text { MATURE (AN OLD) PERSON } \\
\text { TIME CAUSES METAMORPHOSIS }\end{array}$ & $1(3 \%)$ \\
\hline 218. & $\begin{array}{l}\text { A CHILD TURNS INTO AN } \\
\text { ADULT PERSON } \\
\text { TIME CAUSES METAMORPHOSIS }\end{array}$ & $1(3 \%)$ \\
\hline 219. & $\begin{array}{lll}\text { AN ALIVE CHILD IS } & \text { TURNED } \\
\text { INTO A DEAD CHILD } & \\
\text { DEATH OR GOD } & \text { CAUSE } \\
\text { METAMORPHOSIS } & \\
\end{array}$ & $1(3 \%)$ \\
\hline 220. & $\begin{array}{lll}\text { SOULS TURN INTO } & \text { REVIVED } \\
\text { SOULS } & & \\
\text { REVIVAL } & \text { CAUSES } \\
\text { METAMORPHOSIS } & \\
\end{array}$ & $1(3 \%)$ \\
\hline 221. & $\begin{array}{l}\text { GOD TURNS INTO A CHILD } \\
\text { NAME } \\
\text { METAMORPHOSIS }\end{array}$ & $1(3 \%)$ \\
\hline 222. & $\begin{array}{l}\text { GOD TURNS INTO A PERSON } \\
\text { SORROW } \\
\text { METAMORPHOSIS }\end{array}$ & $1(3 \%)$ \\
\hline 223. & $\begin{array}{l}\text { DAY IS TURNED INTO NIGHT } \\
\text { TIME CAUSES METAMORPHOSIS }\end{array}$ & $1(3 \%)$ \\
\hline \multicolumn{3}{|c|}{$\begin{array}{l}\text { The total amount of the conceptual metamorphosises } \\
\text { \%). } \\
\text { Number } 200(29 \%) \text {. } \\
\text { Number } 201 \text { до } 202 \text { номерів - } 5(13 \%) \text {. } \\
\text { Numbers } 203 \text { до } 223 \text { номерів - } 22(58 \%) .\end{array}$} \\
\hline
\end{tabular}

The hierarchy of the conceptual oxymorons reconstructed in the British poetry of the romantic period that fill second additional circle is filled by the conceptual oxymorons (Table 5): 
Conceptual oxymorons reconstructed in the British poetry of the romantic period

\begin{tabular}{|l|l|l|}
\hline \multicolumn{2}{|c|}{$\begin{array}{c}\text { The hierarchy of the conceptual } \\
\text { oxymorons }\end{array}$} & $\begin{array}{c}\text { The total amount of } \\
\text { the realization }(\%)\end{array}$ \\
\hline 224. & DAY (LIFE) IS NOT A JOY & $1(17 \%)$ \\
\hline 225. & A BRITON IS NOT A SLAVE & $1(17 \%)$ \\
\hline 226. & BLOOM IS NOT IMMORTAL & $1(17 \%)$ \\
\hline 227. & JOY IS NOT GRIEF & $1(17 \%)$ \\
\hline 228. & PAIN IS NOT UNBELOVED & $1(17 \%)$ \\
\hline 229. & SILENCE IS NOT INVISIBLE & $1(17 \%)$ \\
\hline The total amount -6. \\
\hline
\end{tabular}

The correlation of the amount of the conceptual tropes in the macrosegment of the fractal poetical model of the world of the romantic period is summarized in the following table (Table 6):

The summarizing results

\begin{tabular}{|c|c|c|c|c|}
\cline { 2 - 5 } \multicolumn{1}{c|}{} & $\begin{array}{c}\text { Conceptual } \\
\text { metaphors } \\
(\%)\end{array}$ & $\begin{array}{c}\text { Conceptual } \\
\text { metonymies } \\
(\%)\end{array}$ & $\begin{array}{c}\text { Conceptual } \\
\text { metamorphosis } \\
\text { es }(\%)\end{array}$ & $\begin{array}{c}\text { Comceptual } \\
\text { oxymorons } \\
(\%)\end{array}$ \\
\hline $\begin{array}{c}\text { The total } \\
\text { amount of } \\
\text { the } \\
\text { conceptual } \\
\text { tropes }(\%)\end{array}$ & $184(66 \%)$ & $51(18 \%)$ & $38(14 \%)$ & $6(2 \%)$ \\
\hline $\begin{array}{c}279 \\
(100 \%)\end{array}$ & \multicolumn{3}{|c}{} \\
\hline
\end{tabular}

\section{CONCLUSIONS}

The fractal poetical model of the world is modelled by us on the basis of the British poetry of the XIX $-\mathrm{XXI}^{\text {st }}$ centuries and our investigation can be perspective because depending on the material of the investigation the fractal model of the world can be constructed not only in the poetry but in the narratology. Thus, the fractal model of the world may be mythological and religious (on the basis of religious and mythological texts), utopian (on the basis of the political texts), historical and philosophical (on the basis of historical and philosophical texts or texts 
that reflect the historical personality/personalities), futrological (on the basis of the texts of the fantasy genre).

Proposed fractal modelling may be perspective in the investigation of the literary work of a poet, an author, an epoch or poets, authors or different cultural and historical periods. We assume that the fractal model of the world may be semiotical including symbols that can be individual and authors, emphatic, eidetic. In the mathematics and in the geometry, in the existing fractal theory, are identified various types of fractals. It is proved that structures the algorithm of the modelling of which is changed spontaneously are superfractals. Multifractals are the complicated fractal structures that consist from several fractal structures. Allatorial fractals fractals in which the smallest outer influence or the outer fluctuations change the form of the whole fractal ${ }^{13}$.

In the linguistic perspective we consider that that the linguistic model may be superfractal segments of which are changed with the integration to the investigation of the text the comparative analysis. The multifractal is the linguistic model that is added by the other linguistic aspect (for example, the combination of the linguistic, the cognitive and the semiotic aspects of the investigation of the texts). The allatorial fractal linguistic model is the model segments of which are changed while the incorporation the new results of the investigation of the text unidentified by the predecessors (e.g., (Fig. 15)):

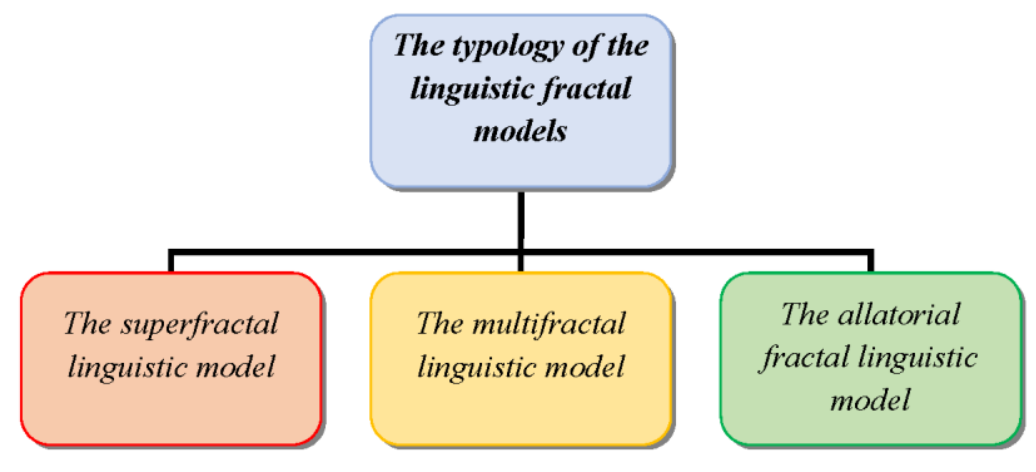

Fig. 15. The proposed typology of the linguistic fractal models

${ }^{13}$ Demenok S. L. (2018) Prosto fraktal. [The Simple Fractal]. SanktPeterburg : Strata. (in Russian) 
The proposed by us methodology of the modelling of the fractal poetical model of the world opens the new paradigm in the modern cognitive linguistics and the cognitive poetics - the cognitive graphics or the cognitive fractal graphics that comprises the combination of the cognitive linguistics, the cognitive poetics, the mathematics, the fractal geometry, the theory of systems, the synergetics. Modelled by us the fractal poetical model of the world is characterized not by the rhizome but the strictly determined structure because the fractal is characterized by the strictly determined structure and consists from the elements of the reductions scale that are self-similar and are excelled by the hierarchical organization, by the recursiveness and by the iteration because the process of the fractal modelling is determined by the multifaceted repetition of the analogical mathematical operations - iterations that are recursive, the final element of the fractal is the beginning of the new element - the recursive. Fractal iterations in our process of the design of the fractal poetical model of the world are the linguistic and the cognitive operations and mechanisms that help the linguists to identify literary concepts and to reconstruct conceptual tropes in the text. Recursiveness is the ability of the micro-segment of the fractal poetical model of the world to be transformed into the frame mode, and the macro-segment - into the integrated mode of emergent conceptual blends. The cognitive fractal graphics is proved in the scientific research by the computer design of the fractal poetical model of the world on the basis of the fractal modelling in the mathematics, in the fractal geometry and in the computer graphics.

\section{SUMMARY}

The article is dedicated to the investigation of the specificity of the reproduction of the reality in the fractal poetical model of the world on the basis of the British poetry of the XIX $-\mathrm{XXI}^{\text {st }}$ centuries with the help of the linguistic, the poetical analysis of the lexical and the semantic tropes as the verbal means of actualization of cognitive processes of the formation of the fractal poetical model of the world and the outlining of the axiological sense that is specific for the cognitive style of poets of the British romantic, modern and postmodern periods by means of the linguistic, the cognitive, the poetic analyses of the above mentioned tropes. The analyses comprises the usage of the cognitive and the discourse strategies of the interpretation of the deepest sense of the fractal poetical model of the world, such as: the reconstruction of the axiological literary concepts as elements of the fractal poetical model of the world, the modelling of the conceptual tropes as the cognitive basis of the 
formation and the designing of the fractal poetical model of the world and the modelling of the conceptual blends and frames as emergent cognitive structures of the embodied understanding in the poetics of the British romantic, modern and postmodern periods.

\section{REFERENCES}

1. Bystrov Ja. V. (2016) Bioghrafichnyj naratyv $u$ linghvokoghnityvnomu vymiri (na materiali anghlomovnoji prozy XX pochatku XXI stolitj) [The Biographical Narrative in the Linguistic and the Cognitive Aspects (on the basis of the English Prose of the $X X^{\text {th }}-$ the beginning of the XXI $I^{\text {st }}$ Centuries] : dys. ... d-ra fil. nauk : 10.02.04 / Kyjivsjkyj nac. linghvistychnyj un-t. Kyjiv. (in Ukrainian)

2. Demenok S. L. (2018) Prosto fraktal. [The Simple Fractal]. Sankt-Peterburg : Strata. (in Russian)

3. Demenok S. L. (2018) Superfraktal. [The Superfractal]. SanktPeterburg : Strata. (in Russian)

4. Moskvychova O. A. (2015) Evoljucija metamorfozy $v$ anghlijsjkomu poetychnomu myslenni : monoghrafija. [The Evolution of Metamorphosis in the English Poetry : the Monograph]. Kherson : Ajlant. (in Ukrainian)

5. Blake W. (2019) The Selected Poems. London : Wordsworth Poetry Library. (in English)

6. Mandelbrot B. B. (1982) The Fractal Geometry of Nature. New York : W. H. Freemanand Company. (in English)

7. Nikonova V., Boyko Y. (2019) Gender-specific emotivity of Victorian female prose from a multidimensional perspective. In Lege artis. Language yesterday, today, tomorrow. Vol. IV (1), pp. 47-82. (in English)

\section{Information about the author: Oksana Moskvichova,}

Candidate of Philological Sciences, Associate Professor, Associate Professor at the Department of the English Language and the Methodology of Teaching, Doctoral Student,

Kherson State University

27, University str., Kherson, 73000, Ukraine ORCID ID: https://orcid.org/0000-0001-7678-5834 


\section{PSEUDOMORPHIC CHARACTERS OF THE NOVEL "THE PHARMACIST" BY YURIY VYNNYCHUK IN THE CONTEXT OF CULTURAL TRADITION (CULTUROLOGICAL FACETS OF ANALYSIS)}

\section{Oleksandra Nikolova, Kateryna Vasylyna}

\section{INTRODUCTION}

The value of the cultural aspect of philological analysis is determined by the prospects of research of artistic texts that reflect mankind's cultural heritage in the figurative form. Firstly, it is necessary to "decode" such achievements as iconic cultural phenomena accumulated during the development of a society in literary works in order to understand the nature of the interaction of tradition and innovation (diachronic approach). Secondly, the analysis of verbal works of art in the cultural context of the current era is carried out with the intention to elucidate those processes that determine the leading trends in the field of literature as a "document of its day" (synchronic approach). And, thirdly, comparative multidirectional studies allow us to rise to the level of broad generalizations and systematically comprehend the importance of certain cultural connections and typological similarities that explicitly attest to the existence of universal values, universal ideas, promote mutual understanding among representatives of different countries, ethnicities etc. And this is only to name a few potential possibilities of such studies.

According to N. Simbirtseva, "the cultural aspect of the philological analysis of a text can be characterized in terms of the values represented by the interaction and complementarity of the chain "time space - personality"; in terms of communication in the sociocultural space that embraces the dialogue of the author of an artwork with themselves, with history, with routine life etc., as well as the close and distant context of the literary text functioning; in terms of the subject-object relations of the writer and culture and the role that the creative individuality of the writer plays in the local sociocultural space" 1 .

${ }^{1}$ Simbirtseva N. A. (2007) Bytije literaturno-khudozhestvennogo proizvedenija: kulturologicheskij aspect [Functioning of a work of fiction: culturological aspect]. Vestnik Chelyabinskogo gosudarstvennogo universiteta, no. 14. P. 28. 
The interplay of cultural studies and philology has a long history, linked to the concept of "race, milieu, and moment" by H. Taine that was substantially enriched by the research of many scientific schools (e.g. "ritualists", representatives of the "Cambridge School" focused on establishing ritual sources of origin of literature, structuralists who are interested in decoding value orientations at the level of binary oppositions in a work of art, etc.), by such well-known scholars as M. Bakhtin ("The Creative Art of François Rabelais and Folk Culture of the Middle Ages and the Renaissance", "Problems of Dostoevsky's Poetics"), Y. Lotman ("The Semiotics of Culture and the Concept of a Text") and others. Unfortunately, it is impossible to provide comprehensive and holistic coverage of all the achievements in this field within the range of our article. However, everything stated before proves that the research in the chosen direction is viable and productive.

At present there are plenty of research papers in which the authors substantiate the importance of cultural studies for philology. For example, the abovementioned study by N. Simbirtseva in which the scholar explains her own methodology of studying literary texts in culturological light which is based on the well-known "theory of dialogue" by M. Bakhtin; T. Betsenko's research ${ }^{2}$ (that characterizes linguocultural approach); the one by L. Komarova ${ }^{3}$ (where important basic principles of cultural analysis of a literary text are identified with the view of concepts of B. Vokhrysheva and Y. Brazgovskaya) etc.

The purpose of this article is to study the novel "The Pharmacist" by Y. Vynnychuk with the view of the culturalogical aspect by selecting and characterizing the pseudomorphic characters of this piece in the context of cultural tradition.

To achieve the main purpose, it is necessary to combine synchronic, diachronic methods of culturology with the genetic and typological approaches of comparative studies in contextual facet.

${ }^{2}$ Betsenko T. (2017) Vydy analizu khudozhnoho tekstu [Types of a literary text analysis]. Visnyk Lvivskoho universytetu. Seriya filolohichna, vypusk 64, ch II. Pp. 239-244.

${ }^{3}$ Komarova L. I. Sovremennyje podhody k izucheniju hudozhestvennogo teksta [Modern approaches to studying a literary text]. Cyberleninka (electronic journal). Retrieved from: https://cyberleninka.ru/article/n/sovremennye-podhody-kizucheniyu-hudozhestvennogo-teksta (accessed: 24 January 2020). 


\section{Scientific background of the research: theoretical basis and main directions of studies that are relevant to solving the stated problem}

The range of phenomena potentially favorable for cultural studies in philology is very broad. Pseudomorphic characters are one of them as they deserve special attention of scholars interested in research of verbal art pieces (myths, folklore, literature) as well as their ceremonial and ritual sources in various cultural contexts (synchronic, diachronic, comparative ones).

Pseudomorphic characters (derived from the ancient Greek "pseudo" - "deceit", "fiction", "mistake" and "morpho" - "form") are the characters whose main feature is "falsehood created as a result of unnatural violation of the correspondence between their essence and its formal presentation / reception, that start to correlate with the opposite categories. Such characters temporarily acquire someone else's likeness, impersonate others, they are inadequately perceived ..." .

It is necessary to single out several main ways of pseudomorphic characters' creation.

“1) Cross-dressing (change of dress, disguise), most often aimed at visual change of gender or social status, i.e. cross-gender" and crossstatus travesty: in the first case, a girl / woman dresses as a man or, vice versa, a man wears a woman's dress, and in the second case the change of clothing indicates a formal transition of a person to another social group, class (in particular, when a noble man pretends to be a beggar, a rogue tries to mislead someone with an expensive suit, etc.).

2) Metamorphosis, accompanied only by a formal transformation with the preservation of the meaningful essence, that is, of consciousness, of intelligence of the person transformed (purely formal metamorphosis). For example, when as a result of magic (spell, voluntary transformation), a person acquires the likeness of an animal, a

${ }^{4}$ Nikolova O. O. (2017) Psevdomorfni personazhi ukrainskoi ta rosiiskoi literatur kintsia XVIII - pershoyi polovyny XIX st. (u konteksti yevropeiskoyi tradytsii). [Pseudomorphic Characters of Ukrainian and Russian Literatures of the Late $18^{\text {th }}-1^{\text {st }}$ Half of the $19^{\text {th }}$ C. (in the Context of European Tradition)]. Zaporizhzhya : Zaporizkyi natsionalnyi universytet. p.5. (in Ukrainian).

${ }^{5}$ Osinovskaya O. S. Kross-gendernoje pereodevanije v pjesah U. Shekspira [Cross-gender change of attire in plays by W. Shakespeare]. Literatures and Languages (electronic journal), vol. 21. Retrieved from: http://svr-lit.ru/svrlit/articles/english/osinovskaya-kross-gendernoe-pereodevanie.htm (accessed: 31 January 2020). 
bird, a plant, and so on, while retaining the ability of thinking, talking and feeling in a human way, or when a supernatural creature appears in an anthropomorphic form to conceal its true nature (humanization of gods, demons, spirits, etc.) ...

3) A verbal and positional pretention aimed at creating a holistic illusion that can accompany travesty, transformation or substitute them.

In the latter case, the character turns to deceptive verbal and behavioral self-presentation and tries to impersonate the other person thus shows unusual mental abilities, moral qualities or, on the contrary, conceals them to produce an impression of one's own importance or worthlessness, etc.

4) Situational mismatch (incongruence between one's essence and its presentation or its perception) means that pseudomorphism arises as a result of a coincidence, play of chance, confusion, misidentification, substitution made by someone else and so on"6.

The potential of the cultural studies of this subject "is predominantly defined by its universal nature: on the one hand, it functions on all the levels of the "triad" of "myth/ ritual - folklore literature" and, on the other hand it is widely-spread at different times in numerous national cultures" and the visually receptive things is one of the eternal themes in creative works of many peoples" ${ }^{\prime}$.

However, despite "popularity" of such characters, comprehensive coverage of the issues of their genesis, criteria of systematization, ways of distribution, trends of transformation, etc. has evolved only recently.

The monograph "Pseudomorphic Characters of Ukrainian and Russian Literatures of the Late $18^{\text {th }}-1^{\text {st }}$ Half of the $19^{\text {th }} \mathrm{C}$. (in the Context of European Tradition)" is the first attempt at systematic study of these

${ }^{6}$ Nikolova O. O. (2017) Psevdomorfni personazhi ukrainskoi ta rosiiskoi literatur kintsia XVIII - pershoyi polovyny XIX st. (u konteksti yevropeiskoyi tradytsii). [Pseudomorphic Characters of Ukrainian and Russian Literatures of the Late $18^{\text {th }}$ $1^{\text {st }}$ Half of the $19^{\text {th }}$ C. (in the Context of European Tradition)]. Zaporizhzhya : Zaporizkyi natsionalnyi universytet. P. 24 (in Ukrainian).

${ }^{7}$ Ibid, p. 22.

${ }^{8}$ Nikolova O. O. (2017) Psevdomorfni personazhi ukrainskoi ta rosiiskoi literatur kintsia XVIII - pershoyi polovyny XIX st. (u konteksti yevropeiskoyi tradytsii). [Pseudomorphic Characters of Ukrainian and Russian Literatures of the Late $18^{\text {th }}-$ $1^{\text {st }}$ Half of the $19^{\text {th }} \mathrm{C}$. (in the Context of European Tradition)]. Zaporizhzhya : Zaporizkyi natsionalnyi universytet. P. 5. (in Ukrainian). 
issues in a limited cultural and historical context ${ }^{9}$. Its conclusions are based on the author's own observations of the trends of functioning of the relevant phenomenon as well as on the achievements of well-known scientists who analyze certain facts in different fields of culture that are either directly or indirectly related to it.

Taking into account a great amount of such papers and without indulging in detailed analysis of each and every one of them, it is possible to categorize them into several groups in accordance with the object of research.

The first group is represented by the studies of the authors who analyze rituals associated with cross-dressing, masking, role swap, imitations, i.e. effective ways of creating temporary dissonance between the visible and the real, the formal and the essential. Works by J. G. Frazer ${ }^{10}$, F. M. Cornford ${ }^{11}$, M. Bakhtin ${ }^{12}$ and others present research of this kind. Scholars often stress upon the links between such rituals and the mythological, folklore and fictional images. The second group is exemplified by the studies of mythologists and folklorists (e.g. I. Sazonovich ${ }^{13}$, Y. Krzhizhanovskiy ${ }^{14}$ ) that are devoted to different characters who pretend to be someone else. The third group is presented by the literary criticism carried out in broad cultural

9 Nikolova O. O. (2017) Psevdomorfni personazhi ukrainskoi ta rosiiskoi literatur kintsia XVIII - pershoyi polovyny XIX st. (u konteksti yevropeiskoyi tradytsii). [Pseudomorphic Characters of Ukrainian and Russian Literatures of the Late $18^{\text {th }}-$ $1^{\text {st }}$ Half of the $19^{\text {th }}$ C. (in the Context of European Tradition)]. Zaporizhzhya : Zaporizkyi natsionalnyi universytet. 450 p. (in Ukrainian).

${ }^{10}$ Frazer J. G. (2001) Zolotaja vetv: issledovanije magii i religii v dvuh tomah [Golden bough: a study of magic and religion in two volumes]. Moskva : TERRA Knizhnyj klub, vol. 1. Pp. 379-386 (in Russian).

${ }^{11}$ Cornford F. M. (1914) The Origin of Attic Comedy. London : EDWARD ARNOLD. Pp. 132-137.

12 Bakhtin M. M. (1990) Tvorchestvo Fransua Rable i narodnaya kultura Srednevekovya i Renessansa [The Creative Art of François Rabelais and Folk Culture of the Middle Ages and the Renaissance]. Moskva: Hudozhestvennaja literatura. 543 p. (in Russian).

13 Sazonovich I. P. (2011) Pesni o devushke-voine $i$ byliny o Stavre Godinoviche : issledovanije po istorii razvitija slavjano-russkogo eposa [Songs about a girl-warrior and epics about Stavr Godunovich]. Moskva : Kniga po Trebovaniju. 183 p. (in Russian).

${ }^{14}$ Krzhizhanovskiy Y. (1963) Devushka-yunosha (k istorii motiva «peremena pola») [A girl-boy (history of the "gender change" motive)]. Russkij folklor, vol. 8. Pp. 56-66. 
context and focused on the characters' travesty in concrete pieces of literature (O. Osinovskaya ${ }^{15}$, G. Uliura $^{16}$, etc.), transformation $\left(\right.$ R. Krokhmalny ${ }^{17}$ ), imposture (Y. Makarenko ${ }^{18}$, M. Lazutkina ${ }^{19}$ ) and so forth.

The monograph "Pseudomorphic Characters of Ukrainian and Russian Literatures of the Late $18^{\text {th }}-1^{\text {st }}$ Half of the $19^{\text {th }} \mathrm{C}$. (in the Context of European Tradition)" 20 suggests a detailed review of the essence of the concepts of all the above mentioned scientists, as well as of other scholars that are meaningful for understanding the nature of pseudomorphic characters. A theoretical and methodological basis for research of this phenomenon is also accessible there ${ }^{21}$.

15 Osinovskaya O. S. Kross-gendernoje pereodevanije v pjesah U. Shekspira [Cross-gender change of attire in plays by W. Shakespeare]. Literatures and Languages (electronic journal), vol. 21. Retrieved from: http://svr-lit.ru/svr-lit/articles/english/ osinovskaya-kross-gendernoe-pereodevanie.htm (accessed: 31 January 2020).

16 Uliura A. (2004) Henderno markyrovannoje pereodevanije kak komicheskoje (na materiale russkoj klassicheskoj literatury) [Gender-marked crossdressing as the comic (case study: Russian classical literature)]. "Dóxa / DOKSA». Zbirnyk naukovykh prats z filosofii ta filolohii, vol. 5. Pp. 335-342.

17 Krokhmalnyi R. O. (2005) Metamorfoza $i$ tekst: semantychna, strukturotvorcha $i$ svitohlyadna rol pereminy khudozhnoho obrazu [Metamorphosis and the text: semantic, structure-making and worldview role of changing a literary image]. Lviv : Vydavnychyi tsentr Lvivskoho nats. un-tu imeni Ivana Franka. 424 p. (in Ukrainian).

${ }^{18}$ Makarenko Y. K. (2002) Zhanrovyj aspekt sjuzheta samozvanstva v russkoy dramaturgii $i$ istoriografii kontsa XVIII - pervoj treti XIX $v v$. [The genre aspect of the plot about impostor in Russian dramaturgy and historiographics of the late XVIII early XIX centuries] (PhD Thesis). Tomsk, $21 \mathrm{p}$.

19 Lazutkina M. G. (2003) Formirovanije hudozhestvennogo obraza samozvantsa Lzhedmitrija I v russkoj literature XVII - XIX vekov [Formation of a fictional image of the impostor Pseudo-Dmitrij I in Russian Literature of XVII XIX centuries] (PhD Thesis), Moskva, $19 \mathrm{p}$.

${ }^{20}$ Nikolova O. O. (2017) Psevdomorfni personazhi ukrainskoi ta rosiiskoi literatur kintsia XVIII - pershoyi polovyny XIX st. (u konteksti yevropeiskoyi tradytsii). [Pseudomorphic Characters of Ukrainian and Russian Literatures of the Late $18^{\text {th }}$ $1^{\text {st }}$ Half of the $19^{\text {th }}$ C. (in the Context of European Tradition)]. Zaporizhzhya : Zaporizkyi natsionalnyi universytet. pp. 12 - 19 (in Ukrainian).

${ }^{21}$ Nikolova O. O. (2017) Psevdomorfni personazhi ukrainskoi ta rosiiskoi literatur kintsia XVIII - pershoyi polovyny XIX st. ( $u$ konteksti yevropeiskoyi tradytsii). [Pseudomorphic Characters of Ukrainian and Russian Literatures of the Late $18^{\text {th }}$ $1^{\text {st }}$ Half of the $19^{\text {th }}$ C. (in the Context of European Tradition)]. Zaporizhzhya : Zaporizkyi natsionalnyi universytet. Pp. 22 - 140. (in Ukrainian). 
As concerns the prospects of pseudomorphic characters' analysis, it is worthwhile mentioning that "research carried out within other .... literary trends, cultural epochs promises interesting findings in the field" ${ }^{22}$. This emphasizes the expediency of broadening the object range of such studies.

This article is aimed at the analysis of pseudomorphic characters in the novel "The Pharmacist" by the contemporary writer Yurii Vynnychuk who is a significant figure in Ukrainian culture of the $21^{\text {st }}$ century. He is known as a journalist, interpreter, editor and the author of a lot of novels ("Malva Landa", "Springtime Games in Autumn Gardens", "Pears in Dough", "Tango of Death", "The Pharmacist", "Sisters of Blood", "Lutetia", etc.), he has been awarded with literary prizes ("Golden Ukrainian Writers", "BBC Book of the Year").

"The Pharmacist" (2015) by Y. Vynnychuk attracts the attention of critics and scholars who analyse different aspects of the novel: Y. Vitiak ${ }^{23}$, O. Kotsarev ${ }^{24}$, T. Litvinchuk ${ }^{25}$, A. Panchenko ${ }^{26}$, I. Tsikhotskii and I. Borosovska ${ }^{27}, \mathrm{~S}$. Cherniuk ${ }^{28}$ etc.

${ }^{22}$ Ibid, p. 387.

23 Vitiak Y. (2016) Literaturna farmatsevtyka. Mizh panatseieiu i platsebo [Literary pharmaceuticals. Between the panacea and placebo]. Literaturnyi Ternopil, no 2, pp. 83-84.

${ }^{24}$ Kotsarev O. «Aptekar» Vynnychuka: vidmy, katuvannia, strashni mahichni knyzhky, balzamy, otruty i troshky seksu ["The Pharmacist" by Vynnychuk: witches, tortures, horrible magic books, balms, poisons and a little sex]. Тексти.org.иа [Texts.org.ua] (electronic journal). Retrieved from: http://texty.org.ua/pg/article/ editorial/read/63534/Aptekar_Vynnychuka_vidmy_katuvanna_strashni_magichni_kny zhky (accessed 10 January 2020).

${ }^{25}$ Litvinchuk T. V. (2017) Lokus domu v serednovichnomu Lvovi (na materiali romanu «Aptekar» Yuriia Vynnychuka) [Locus of home in medieval Lviv (Yurii Vynnychuk's "The Pharmacist": case study)]. Literaturoznavchi studii, vol. 1(2), pp. 32-40.

${ }^{26}$ Panchenko A. (2016) Chytajem ukrainskoje: Retsenzija na knigu «Aptekar» Yurija Vinnichuka [Reading Ukrainian: review of the book "The Pharmacist" by Yurii Vynnychuk]. Segodnia [Today] (electronic journal). Retrieved from: https:// ukr.segodnya.ua/lifestyle/showbiz/chitaem-ukrainskoe-recenziya-na-knigu-aptekar-yuriyavinnichuka-701314.html (accessed 20 December 2019).

27 Tsikhotskii I., Borosovska I. (2018) Starolvivska beletrystyka Yuriia Vynnychuka: avtorska kontseptsiya movnoho istoryzmu (na materiali romanu «Aptekar») [Old-Lviv belles-lettres by Yurii Vynnychuk: author's concept of language historicism (novel "The Pharmacists": case study)]. Visnyk Lvivskoho universytetu. Seriya filolohichna, vol. 68, pp. 30-47. 
Regardless of the point of view, the majority of scientists claim that "The Pharmacist" exposes a strong connection with the cultural context: "communicative rhizomatics",29, intertextuality, "dialogism" with the "texts" of different eras and countries.

According to S. Cherniuk, the "encyclopedia" (according to U. Eco) of the implicit reader of "The Pharmacist" may a priori contain not only the works of the sixtiers-eightiers but also an immense (and indefinite) list of foreign authors, most obviously of "Perfume" by Patrick Süskind, "Decameron" by Giovanni Boccaccio, or of oriental fairy tales for sure by Wilhelm Hauff, "The Name of the Rose" by Umberto Eco, "The Witches of Eastwick" by John Updike, of important proto-texts outlined by the writer himself" ${ }^{30}$. The scholar also emphasizes the correlation of the novel with different genre forms: of "mass literature such as adventure, rogue, detective, love, fantastical, thrash, thriller, of black humor, folk-medicine, as well as of the ones aimed at a more experienced reader e.g. historical, political, historical medical, alchemical-apothecary, philosophical, antiquary or, more broadly, with meta-prose literature, literature about literature" $" 31$.

At the same time, despite the popularity of "The Pharmacist" among the scientific community of Ukraine, the question of functioning of pseudomorphic characters in its artistic world still remains unsettled. However, S. Cherniuk points out that the image of the "travesty transvestite Yuliana-Lorenzo" evokes associations with Boccaccio's "Decameron" and works by Shakespeare: "the intertextuality of both names may have been due to the combination of the names of the two Medici brothers, of whom Lorenzo was, among other things, a writer who had active dispute with Savonarola"32.

${ }^{28}$ Cherniuk S. L. (2016) Komunikatsiina ryzomatyka romanu Y. Vynnychuka «Aptekar» [Communication rhizomatics of Yurii Vynnychuk's novel "The Pharmacist"]. Nuakovi pratsi Chornomorskogo derzhavnoho universytetu imeni Petra Mohyly kompleksu "Kyevo-Mohylianska Akademiia”, vol. 276, no. 264, pp. 121-126. Retrieved from: http://nbuv.gov.ua/UJRN/Npchdufl_2016_276_264_23 (accessed 11 November 2019).

${ }^{29}$ Ibid.

${ }^{30}$ Ibid.

${ }^{31}$ Ibid.

${ }^{32}$ Cherniuk S. L. (2016) Komunikatsiina ryzomatyka romanu Y. Vynnychuka «Aptekar» [Communication rhizomatics of Yurii Vynnychuk's novel "The Pharmacist"]. Nuakovi pratsi Chornomorskogo derzhavnoho universytetu imeni Petra 
However, there is still no comprehensive, systematic coverage of the problem in its cultural aspect accompanied by a convincing argumentation of the traditional character of the motives of impersonation and pretention used by Y. Vynnychuk. Our research is intended to fill the existing lacuna.

\section{Cross-gender travesty (the image of Yuliana-Lorenzo) in the context of cultural tradition}

There are different pseudomorphic characters acting in "The Pharmacist". The most notable is the image of a girl Yuliana by name who engages herself in cross-gender travesty: she pretends to be a young man named Lorenzo in order to obtain medical education, to master a "male" profession of a surgeon (the action is set in the $17^{\text {th }}$ century) and to revenge upon her sister's murderer.

"Surgery? I have some grasp of it. Because I studied at the university in Padua. - It's impossible! No women can enter there. - And who told you that I was a woman? I was a boy. I got disguised as a boy and so I studied during all those years" ${ }^{33}$.

While playing her male role for a long time, Yuliana not only learned how to perform operations, fence skillfully and speak in a rough voice, but also got rid of a purely female vulnerability and sensuality: "I've learned to be cold, and no death will ever move me" ${ }^{34}$. So, it is not surprising that the heroine kills all her sister's rapists, one by one, she does it in cold blood and, having completed her revenge, she leaves the city unsuspected and unhindered.

The image of Yuliana-Lorenzo neatly fits into the context of cultural tradition, since the history of cross-gender travesty goes back to ancient rites, continues its development in myths and folklore of different peoples. It is also enriched by many attributes due to the development of literature, in the first place, and later through cinematography.

Though there is a debate among scholars about the essence of ritual and ceremonial dressing in the attire of the opposite sex, still everyone

Mohyly kompleksu “Kyevo-Mohylianska Akademiia”, vol. 276, no. 264, pp. 121-126. Retrieved from: http://nbuv.gov.ua/UJRN/Npchdufl_2016_276_264_23 (accessed 11 November 2019).

${ }^{33}$ Vynnychuk Y. (2015) Aptekar [The Pharmacist]. Kharkiv: Folio, p. 183 (in Ukrainian).

${ }^{34}$ Ibid, p. 184. 
acknowledges the fact of its existence in many cultures. For example, V. Propp points out that this custom "has been extremely widespread throughout Europe since antiquity"35, but "it is difficult to explain, and there is no complete clarity in its meaning and sense till this day" 36 . M. Bakhtin argues that this phenomenon is typical of carnival performances related to the destruction of traditional social norms: "We observe it first of all in the participants' clothes. Men are dressed as women and vice versa..."37. O. Freidenberg interprets "female-male travesty" as a metaphor of sexual contact: "a woman becomes a man, a man becomes a woman" 38 .

The range of folklore genres in which the corresponding motifs are used to the best effect is quite wide and embraces ballads, songs, epics, romances, fairy tales, legends and so on. For example, $\mathrm{O}$ Miller $^{39}$, I. Franko ${ }^{40}$, I. Sazonovich ${ }^{41}$, Y. Krzhizhanovskiy ${ }^{42}$ and others pay special attention to the "popularity" of the image of a "maiden warrior" in the folk art of different countries. The international system of classification of fairy tales suggested by A. Aarne and S. Thompson singles out the plots of such types as: "The

35 Propp V. Y. (2000) Russkije agrarnyje prazdniki. Opyt istorikoetnograficheskogo issledovanija [Russian agrarian holidays. Experience of historical and ethnographic research]. Moskva : Labirint, p. 137 (in Russian).

${ }^{36}$ Ibid, p. 137.

37 Bakhtin M. M. (1990) Tvorchestvo Fransua Rable i narodnaya kultura Srednevekovya i Renessansa [The Creative Art of François Rabelais and Folk Culture of the Middle Ages and the Renaissance]. Moskva: Hudozhestvennaja literature, p. 454 (in Russian).

${ }^{38}$ Freidenberg O. M. (1997) Poetika sjuzheta i zhanra [Poetics of plot and genre]. Moskva : Labirint, p. 95 (in Russian).

${ }^{39}$ Miller O. F. (1869) Ilja Muromets i bogatyrstvo Kijevskoje [Ilya Muromets and Kyiv bogatyrs]. Sankt-Peterburg : Tipografija N. N. Mikhajlova, p. 635-637 (in Russian).

${ }^{40}$ Franko I. (1984) Divchyna-voiachka [A girl-warrior]. Zibrannia tvoriv $u$ 50 -ty $t$. [Collection of works in 50 volumes]. Kyiv : Naukova dumka, vol. 42, pp. 225-229.

41 Sazonovich I. P. (2011) Pesni o devushke-voine i byliny o Stavre Godinoviche : issledovanije po istorii razvitija slavjano-russkogo eposa [Songs about a girl-warrior and epics about Stavr Godunovich]. Moskva : Kniga po Trebovaniju, 183 p. (in Russian).

${ }^{42}$ Krzhizhanovskiy Y. (1963) Devushka-yunosha (k istorii motiva «peremena pola») [A girl-boy (history of the "gender change" motive)]. Russkij folklor, vol. 8 . pp. 56-66. 
Abandoned Bride Disguised as a Man" AT 881, "The Forsaken Fiancée: Service as a Menial" AT 884, "The Girl as Soldier" AT 884 etc. The fairytale plot "The Active Heroine Disguised as a Man Saves a Man from Trouble" (AT 880, 881, 881A, 882, 883B, 887, 888, $888 \mathrm{~A})$ is analyzed in detail by Ye. Meletinskiy ${ }^{43}$.

As for literary studies, according to G. Uliura, "the theme of crossdressing (in the broadest sense of the term ranging from the change of social status to carnivalization of gender) is probably the most important and nearly the least studied of all the variety of topics that form the field of interest of gender studies in literary criticism" "44. This gap is to some extent filled by the results of the research presented in the monograph "Pseudomorphic Characters of Ukrainian and Russian Literatures of the Late $18^{\text {th }}-1^{\text {st }}$ Half of the $19^{\text {th }}$ C. (in the Context of European Tradition)", which highlights quite a number of works of art that use this material.

It is necessary to note that "Literary life of various motives with cross-gender dressing continues in novelistics (the third and ninth novellas of the second day of "Decameron" by Giovanni Boccaccio, "The Novel of How the Revelation Source was Discovered" by A. de Eslava, "New Pastimes and Merry Chats" by Bonaventure des Périers, "Pachecos and Palomeques" by Gonzalo de Céspedes y Meneses, "El Patrañuelo" by Juan de Timoneda, "The Fortunes of Diana" by Lope de Vega, etc.), dramaturgy ("Castrucho the Pimp" by Lope de Vega, ... "Life is a Dream" by Pedro Calderón de la Barca, "Don Gil of the Green Breeches" by T. de Molina, "The Servant of Two Masters" by C. Goldoni, "The Merry Wives of Windsor", "The Merchant of Venice", "The Two Gentlemen of Verona", "The Twelfth Night or What You Will", "As You Like It" by W. Shakespeare, "The Headstrong Woman" by H. KvitkaOsnovianenko etc.), stories and novels ("Natalia, the Boyar's Daughter" by M. Karamzin, "Chaikovskii" by Y. Hrebinka, "The Foundation of Kharkov" by H. Kvitka-Osnovianenko), hagiographical literature ("The Life of Reverend Apollinaria", "The Life of Our Reverend Mother Xenia"... and others) etc.

${ }^{43}$ Meletinskiy Ye. (1990) Istoricheskaja poetika novelly [Historical poetics of novella]. Moskva: Nauka, p. 13 (in Russian).

44 Uliura A. (2004) Henderno markyrovannoje pereodevanije kak komicheskoje (na materiale russkoj klassicheskoj literatury) [Gender-marked crossdressing as the comic (case study: Russian classical literature)]. "Dóxa / DOKSA». Zbirnyk naukovykh prats z filosofii ta filolohii, vol. 5, p. 335. 
In the last of the genre traditions listed above, dressing of a woman in men's attire is prompted by her desire to serve God" "45.

Scholars also testify the spread of "Popesse Joanna" plot in WestEuropean and East-Slavic literatures: it is about the seizure of "papal authority by a young woman who obtains (due to good theological education received by her in a male likeness) a high position in Catholic hierarchy and even the papal throne for some time, from which she is dismissed by the angry people"

O. Osinovskaya, while analyzing tendencies in the functioning of cross-gender travesty in Shakespeare's plays, states the following: "...usage of "someone else's" clothing results either in increase or decrease of one's status. A man, putting on women's clothing, lost those powers, rights and authority that the "strong" sex usually possesses... Women, on the contrary, receive much more mobility in men's clothing. They become more influential in their new environment" 47 , they acquire many more rights: women's crossdressing as the one directed up the social hierarchy of Elizabethan society is justified and rewarded ${ }^{48}$.

In general, the analysis of the cultural tradition associated with the usage of plots in which a girl imitates a man gives possibility to identify several leading motives of such travesty: 1) love (rescue or return of a loved one, of a man); 2) desire to establish justice (revenge on the traitor, slanderer, criminal, etc.); 3) fight for gender equality, i.e. desire to "prove one's suitability for some serious, "male" business, profession, etc." "49.

45 Nikolova O. O. (2017) Psevdomorfni personazhi ukrainskoi ta rosiiskoi literatur kintsia XVIII - pershoyi polovyny XIX st. ( $u$ konteksti yevropeiskoyi tradytsii). [Pseudomorphic Characters of Ukrainian and Russian Literatures of the Late $18^{\text {th }}-$ $1^{\text {st }}$ Half of the $19^{\text {th }}$ C. (in the Context of European Tradition)]. Zaporizhzhya : Zaporizkyi natsionalnyi universytet. p. 63 (in Ukrainian).

${ }^{46}$ Veselovsky A. N. (1870) Starinnyj teatr $v$ Yevrope [Ancient theatre in Europe]. Moskva : V tipografii P. Bakhmeteva, p. 59 (in Russian).

${ }^{47}$ Osinovskaya O. S. Kross-gendernoje pereodevanije v pjesah U. Shekspira [Cross-gender change of attire in plays by W. Shakespeare]. Literatures and Languages (electronic journal), vol. 21. Retrieved from: http://svr-lit.ru/svr-lit/articles/english/ osinovskaya-kross-gendernoe-pereodevanie.htm (accessed: 31 January 2020).

48 Ibid.

49 Nikolova O. O. (2017) Psevdomorfni personazhi ukrainskoi ta rosiiskoi literatur kintsia XVIII - pershoyi polovyny XIX st. ( $u$ konteksti yevropeiskoyi tradytsii). [Pseudomorphic Characters of Ukrainian and Russian Literatures of the Late $18^{\text {th }}$ $1^{\text {st }}$ Half of the $19^{\text {th }}$ C. (in the Context of European Tradition)]. Zaporizhzhya : Zaporizkyi natsionalnyi universytet. P. 64 (in Ukrainian). 
The presence of the pseudo-Lorenzo in Y. Vynnychuk's novel is not in any way connected with love, at the same time two other motives remain relevant, which demonstrates the peculiar "emancipation" of the heroine, whose need for self-realization, professional growth and protection of her sister's honor are of paramount importance. So, crossgender travesty is a consequence of Yuliana's awareness of the need to fight for women's rights in patriarchal society (the right for education, work, justice). Everything mentioned above gives reason to integrate this cross-dressing plot of "The Pharmacist" in the cultural context of modernity, because Yuliana's position represents the position of a Ukrainian woman of the $21^{\text {st }}$ century rather than that of a girl of the $17^{\text {th }}$ century.

The so-called "motive of deception of feelings" 50 , typical of the cultural tradition, is also updated in the novel. It is the case when a pseudomorphic character evokes the sympathy of a representative of their own sex, who is not aware of the fraud.

The corresponding narrative cliché is used, for example, in Novella III (LXXIV 1-3) of "Novellino", "Castrucho the Pimp", "The Fortunes of Diana" by Lope de Vega, "Anconitanka" by A. Beolko, "The Adventures of a Beautiful Muslim Woman" by Antoine François Prévost d'Exiles, "The Twelfth Night, or What You Will" by W. Shakespeare and many more. Analyzing this motif in a comedy by W. Shakespeare, O. Anikst notes that the "triangle" of "Olivia - Orsino - Viola" was borrowed from Barnaby Rich ("Farewell to Military Profession", 1581), at the same time this plot-line had a long life: "It first appeared in the Italian comedy "The Confused" (1531), then in one of the novels by Bandello (1554), from which it passed over to François de Belleforest and from there it arrived in England"51.

Such "deception of feelings" is generally typical of the Renaissance drama: "A hero is in love, the subject of his passion has affection to another one who (the girl disguised as a man) has given the heart to a boy who is in love without reciprocity ("The Deceived"). It is clear that no one can get out of this maze without loss unless a fourth partner is involved

50 Anikst A. (1989) Dvenadtsataya noch, ili Chto ugodno [Twelfth Night or What you will]. Angliyskaya komediya XVII - XVIII vekov : antologiya [English comedy of 17th-18th centuries]. Moskva: Vysshaya shkola, p. 736.

51 Anikst A. (1989) Dvenadtsataya noch, ili Chto ugodno [Twelfth Night or What you will]. Angliyskaya komediya XVII - XVIII vekov : antologiya [English comedy of $17^{\text {th }}-18^{\text {th }}$ centuries]. Moskva: Vysshaya shkola, p. 735. 
who would accept love that is non-productive, aimed at a representative of the same-sex, that is, unless a circular structure is transformed into a paired one (and the fourth part, the twin-brother of that girl who has adopted another gender is sure to appear), ${ }^{, 52}$.

In the novel by Y. Vynnychuk a country girl Ruta falls in love with Yuliana-Lorenzo and she is sure that it is the best man in the world. "Stammering and hurrying, missing words and individual sounds, Ruta confessed her feelings to Lorenzo, starting with the fact that it had happened to her for the first time, that she had never loved anyone so much, all the time since Lorenzo appeared in her life, she had loved him, and it seemed to her that he might also have some feelings to her" ${ }^{\prime 53}$. At the same time the situation is getting more complicated because the pharmacist (Lukash) sympathizes with Yuliana as a girl.

However, while in the classic version of the plot the conflict is resolved in a traditional way, it is otherwise settled in the novel by Y. Vynnychuk. An unexpected thing happens as soon as all the truth about the gender of the "fair knight" is revealed: Yuliana kisses the girl named Ruta. "Juliana pressed Ruta to her breast and kissed her on the lips with such passion that Ruta got dizzy ..." ${ }^{, 54}$. But in the finale of the novel Ruta at last realizes that it is Lukash who is her true love. Thus after disappearance of pseudo-man Yuliana, the boy and the girl who used to be in love with her finally find each other.

\section{Franz and Lukash as pseudomorphic characters and carnivalesque nature of the novel in the context of cultural tradition}

Another pseudomorphic character of "The Pharmacist" is a devil that during the development of action in the piece pretends to be an ordinary man. The infernal creature turns into an attractive young man named Franz: “.. a skinny, slender young master dressed in German fashion came into the house ... - Ah, it's you, rascal - the witch

${ }^{52}$ Andreyev M. L., Khlodovskiy R. I. (1988) Italyanskaya literatura zrelogo $i$ pozdnego Vozrozhdeniya [Italian literature of high and late Renaissance]. Moskva : Nauka, p. 181 (in Russian).

${ }^{53}$ Vynnychuk Y. (2015) Aptekar [The Pharmacist]. Kharkiv: Folio, p. 235 (in Ukrainian).

${ }^{54}$ Ibid, p. 285. 
recognized the familiar devil, who hadn't visited her for a long time" ${ }^{, 55}$. It is in this appearance that he stays among people.

The cultural tradition connected with the idea of the possibility of humanization of supernatural creatures (gods, spirits, demons, etc.) who in an anthropomorphic form are unrecognized and act in the earthly world, is rooted in ancient times: many myths and folklore of different peoples are illustrative in this respect ${ }^{56}$. "... the motive of deceptive humanization of a demonic creature can be associated with the typical Christian notion of the devil as a fraudster who resorts to various tricks to ruin as many souls as possible. Numerous fairytales, legends and ballads of different nations tell how the constant antagonist of God travels the world in the image of a human, tempting the credulous and indulging their passions" 57 .

In the fiction of the $18^{\text {th }}-20^{\text {th }}$ centuries the image of a humanized infernal is often associated with such motive as "a man makes a deal with the devil": here it is necessary to mention J. W. Goethe ("Faust"), J. Cazotte ("The Devil in Love"), A. von Chamisso ("Peter Schlemihl's Miraculous Story"), V. Hauff ("The Cold Heart"), M. Gogol ("Evening on the Eve of Ivan Kupala"), M. Zagoskin ("The Tempter"), L. Andreev ("Diary of Satan"), J. Krus ("Timm Thaler, or the Traded Laughter"), M. Bulgakov ("The Master and Margarita") etc.

The image of the anthropomorphic devil was created by Y. Vynnychuk in accordance with the best examples of this cultural tradition: there are many significant allusions in the text of "The Pharmacist" that actualize associations with various works that form the context of "cultural demonology".

For example, an intimate friendship with the witch is depicted in the spirit of "The Night Before Christmas" by M. Gogol: Franz and Vivdia drink vodka together, eat bacon and talk about life as old companions. Emphasis on the German costume as well as the German name of the devil, his role of a "servant" of the alchemist named

${ }^{55}$ Vynnychuk Y. (2015) Aptekar [The Pharmacist]. Kharkiv: Folio, p. 40 (in Ukrainian).

${ }^{56}$ Nikolova O. O. (2017) Psevdomorfni personazhi ukrainskoi ta rosiiskoi literatur kintsia XVIII - pershoyi polovyny XIX st. (u konteksti yevropeiskoyi tradytsii). [Pseudomorphic Characters of Ukrainian and Russian Literatures of the Late $18^{\text {th }}-$ $1^{\text {st }}$ Half of the $19^{\text {th }}$ C. (in the Context of European Tradition)]. Zaporizhzhya : Zaporizkyi natsionalnyi universytet. p.p. 85-88 (in Ukrainian).

${ }^{57}$ Ibid, p. 91. 
Kalkbrenner reminds a knowledgeable reader not only of J. W. Goethe's "Faust", but also of the chapbook "Historie of Johann Faust, the Infamous Magician and Necromancer" (as Kalkbrenner's name is Johann). Vivdia's salvation from prison, eagerness to find the murderers of Yuliana's sister, to help the innocent Lukash, who is at risk of execution ("I can sometimes go against my principles and do a good deed"58), all these events allow to draw parallels between Franz's image and M. Bulgakov's "kind" Woland. Mentioning "my friend Pilate" is also reminiscent of "The Master and Margarita".

Y. Vynnychuk's pseudomorphic character is not an embodiment of absolute evil, he is rather a cunning rogue, a trickster, a joker: in this aspect he looks like a travesty devil, the "crook, mocker, brawler" of folk theatre, fairy tales and legends ${ }^{60}$.

Franz gladly pokes fun at the sermons in the church, knows how to insert a sharp word in time; his favorite sphere is a play on the verge of illusion and reality, when the boundary between common norms and ideas is blurred: in such a carnival atmosphere, the hellish rogue feels quite organic. Therefore, among all masks for the holiday of Morana (something like modern Halloween), he chooses the most suitable one and that is of his own visage: "you will be a very nice vampire. I will be a werewolf, Amalia will be an old witch, and Franz... well, Franz will be...- Oh, dear Johann, - Franz grimaced, blushing pretentiously and putting on his devil mask, - you should not make wrongful use of name. I'll be just Franz"61.

At the same time, the humanized infernal creature of "The Pharmacist" as well as Yuliana-Lorenzo, seems to be functioning at the intersection of past and present. The basis for considering the image of a girl disguised as a man in the context of the cultural realities of modernity is provided by her progressive, "feministic" views. While in the case of anthropomorphic fiend the ground for this is his true awareness of these realities (because the devil is able to travel in time).

${ }^{58}$ Vynnychuk Y. (2015) Aptekar [The Pharmacist]. Kharkiv: Folio, p. 311 (in Ukrainian).

${ }^{59}$ Ibid, p. 304.

60 Shchytova-Romanchuk L. A. (2000) Tvorchist Hodvina v konteksti romantychnoho demonizmu [Godwin's creative activity in the context of romantic demonism] (PhD Thesis), Dnipropetrovsk: DDU, p. 6.

${ }^{61}$ Vynnychuk Y. (2015) Aptekar [The Pharmacist]. Kharkiv: Folio, p. 267 (in Ukrainian). 
Supporting Kalkbrenner's words that the moon makes women "... brawlers, flirts", Franz notes: "- as well as feminists... - What did you say? - Johan was surprised. - What the hell are feminists? - Ah, but these are the monsters who will make their appearance in two hundred years, laughed Franz" ${ }^{\prime 62}$.

Thus, the ambivalence of this pseudomorphic character of the Ukrainian writer's novel (as well as that of Yuliana-Lorenzo), is determined not only by the contradiction between his essence and appearance, but also by his simultaneous belonging to the cultural tradition of the past and present.

The narrator (Lukash Hulevich) is also a pseudomorphic character: the young man substitutes his late friend Martin. Before his death, the latter insisted on such a "performance": "All my papers and the stryiko's (uncle's) will are there. There's also some money there. I will all the same die, you can take advantage of this. Stryiko had no other relatives but me. You will say that you are me, Martin Airer from Salzburg" "63.

So Lukash becomes the owner of a pharmacy and still he has no rights for it. His image supplements the gallery of simulators, imitators of the novel: "Yuliana thought that Lukash is just living another life, Martin's life, as she lives the life of some non-existent Lorenzo, there are already three of them who live someone else's lives ...,"64.

Lukash is, in fact, an impostor, for he annexes another person's property, while obtaining material gain and status in society, which he would not have had under other circumstances. In this aspect, Y. Vynnychuk's pharmacist relates to pretenders of a wide cultural context who groundlessly appropriate someone else's belongings - the throne (self-proclaimed rulers), wealth (pseudo-rich man), the bride (pseudo-betrothed) and the like. A detailed review of these types is presented in the monograph "Pseudomorphic Characters of Ukrainian and Russian Literatures of the Late $18^{\text {th }}-1^{\text {st }}$ Half of the $19^{\text {th }} \mathrm{C}$. (in the Context of European Tradition)" ${ }^{\text {"65 }}$.

${ }^{62}$ Ibid, p. 226.

${ }^{63}$ Ibid, p. 18.

${ }^{64}$ Vynnychuk Y. (2015) Aptekar [The Pharmacist]. Kharkiv: Folio, p. 285 (in Ukrainian).

${ }^{65}$ Nikolova O. O. (2017) Psevdomorfni personazhi ukrainskoi ta rosiiskoi literatur kintsia XVIII - pershoyi polovyny XIX st. (u konteksti yevropeiskoyi tradytsii). [Pseudomorphic Characters of Ukrainian and Russian Literatures of the Late $18^{\text {th }}-$ 
In his function Lukash Hulevich is most similar to the pseudo-hero of a fairy tale, distinguished and characterized by V. Propp ${ }^{66}$, because he occupies the place of the one who is legally entitled to enjoy the benefits of life (in the fairy tale it is the throne and wife, in the piece by Y. Vynnychuk it is the title of the "royal" pharmacist).

However, this similarity is only a formal one. After all, Lukash, firstly, is not guilty of Martin's death, while a fabulous pseudo-hero kills the seeker, Martin dies at the hands of an unknown murderer. Secondly, he does not declare himself an heir to the pharmacist by his own will (pseudohero is driven by mercenary motives, Lukash executes the will of his dying friend). And finally, he gets no punishment after the resurrection of the true hero and his own exposure (Lukash's friends know about the swap and they all keep this secret). Thus, the pharmacist from the novel of the same name compares favourably with the impostors, since his substitution is imposed, noble, in no way connected with the deceitful and criminal methods of achieving the goal.

The analysis of the pseudomorphic characters of the novel by this Ukrainian writer in the context of cultural tradition makes it possible to draw conclusions about their specificity: all the pretenders in "The Pharmacist" feel much better in their mask than without it. The mask helps them to act according to their true needs and goals.

Yuliana disguised as a man lives a much more interesting, more fulfilling life than the one she would be destined to live as a girl: for comparison one can take the story of her twin sister, raped and murdered by rich young men ("Because she is nobody. She has no more rights for her life than any ants" ${ }^{, 67}$ ). In fact, it is only in the costume of a man that Yuliana becomes herself, she is a strong, determined, courageous, skilled surgeon, a fair executioner for those who put themselves above the law.

The devil in the image of Franz plunges into the very whirlpool of human passions, enjoying earthly revelry more than his existence in hell.

\footnotetext{
$1^{\text {st }}$ Half of the $19^{\text {th }}$ C. (in the Context of European Tradition)]. Zaporizhzhya : Zaporizkyi natsionalnyi universytet. Pp. 56-58 (in Ukrainian).

${ }^{66}$ Propp V. Y. (1946) Istoricheskije korni volshebnoj skazki [Historical roots of a Fairy-tale]. Leningrad : Izd-vo Leningradskogo gosudarstvennogo ordena Lenina universiteta, p. 137 (in Russian).

${ }^{67}$ Vynnychuk Y. (2015) Aptekar [The Pharmacist]. Kharkiv: Folio, p. 4 (in Ukrainian).
} 
"In hell, you know, everyone has their own occupation. Still, making tricks is much more fun than suffering near sinners' boilers" $"$.

When Lukash plays the role of his deceased friend Martin, he gets a possibility to help others, to test in practice and to improve his knowledge of medicine, he also finds true love.

Paradoxically, pseudomorphism provides Y. Vynnychuk's characters with the ability to realize their own essence, while, according to traditional views, a mask is to deprive one of one's self, level one's personality: through masking, cross-dressing one loses their identity. In many cultures of ancient times, this was reflected in various archaic ceremonies, where any ritual actions aimed at violating the correspondence between the true nature of a human and its formal presentation/reception (exchanging the clothes, covering-up the face, swapping status etc.) meant symbolic death ${ }^{69}$.

Here one can mention, for example, the calendar (Kronia, Saturnalia, Maslyana, carnivals, etc.) and social (initiations, marriage and so on) "transitional rituals", " "a mandatory component of which is a formal role inversion, substitution as a reflection of a permanent mutual transition of life and death. It is about temporarily role swapping between lords and slaves in Kronia and Saturnalia, cross-gender travesty, election of profane kings and popes, use of costumes / masks of animals, strangers, monsters, appearance of counterfeit brides at weddings, imitation of death that is vital for initiation, "carnival funerals", substitution of a person by their artificial image etc." $"$

In the context of the carnival cultural traditions pseudomorphic characters are typical functional types and represent one of those

${ }_{69}^{68}$ Ibid, p. 42.

69 Mednikova M. B. (2004) Fenomen maski v traditsionnoj kulture: simvolicheskaja priroda sposoba ritualnogo prevrashchenija [Phenomenon of a mask in traditional culture: symbolic character of the way of ritual metamorphosis]. Livejournal. (electronic journal). Retrieved from: https://svart-ulfr.livejournal.com/ 207940.html (accessed 12 January 2020).

${ }^{70}$ Gennep Arnold van. (2002) Obrjady perehoda: Sistema izuchenija obrjadov [Rituals of transition: system of studying the rituals]. Moskva: «Vostochnaja literatura» RAN, p. 15 (in Russian).

71 Nikolova O. O. (2017) Psevdomorfni personazhi ukrainskoi ta rosiiskoi literatur kintsia XVIII - pershoyi polovyny XIX st. (u konteksti yevropeiskoyi tradytsii). [Pseudomorphic Characters of Ukrainian and Russian Literatures of the Late $18^{\text {th }}-$ $1^{\text {st }}$ Half of the $19^{\text {th }}$ C. (in the Context of European Tradition)]. Zaporizhzhya : Zaporizkyi natsionalnyi universytet. P. 33 (in Ukrainian). 
significant connections that allow to include various synchronically and diachronically different phenomena into cultural comparative analysis (for example, ancient myths and rituals, folklore and literary texts).

Carnivalesque atmosphere in the artistic world of Y. Vynnychuk's novel is created not only with the help of introduction of pseudomorphic characters, but also by depictions of Morana's festivities, which are also intended to unite the past and the present in the mind of a conscious recipient. Morana's Day is associated with medieval carnivals, various carnival-type festivals, characterized in detail by M. Bakhtin as well as with the contemporary Halloween.

M. Bakhtin points out that "carnival life" is "a life removed from its usual track, to a certain extent its "life inside out", "inverse world" ("monde a l'envers"),"72, "carnival brings together, unites, betroths and combines the holy and the profane, the high and the low, the grandiose and the miserable, the reasonable and the unreasonable, etc."73, "everything that was closed, disconnected, distant from each other by the beyond-carnival hierarchical worldview enters into carnival contacts and combination",74.

A whole chapter in the novel by Y. Vynnychuk is devoted to Morana's Day, the first part of which is almost entirely based on reminiscences of M. Bakhtin's famous works. On this day Lviv's inhabitants dress up in the costumes of the dead, their ancestors, thus creating the illusion of their resurrection, which, in its turn, is to symbolize the spring revival of nature after winter. Simple laymen also have fun and enjoy themselves, arranging a kind of large-scale performance with the participation of different carnival monsters representatives of the dark world (witches, ghouls, devils, etc.).

"People needed entertainment, possibility to spill out all their passions and to sink into a reverie at least for a while. The holiday of Morana, when the dead were remembered, did not in any way resemble the Day of all the dead, when the dried flowers, fallen leaves, rains, gloomy days and long nights cause fatigue and desire to fall asleep, when

72 Bakhtin M. M. (2002) Problemy poetiki Dostoevskogo [Problems of Dostoevsky's poetics]. Moskva-Augsburg : «Im-Werden-Verlag», 2002, p. 71 (in Russian).

Bakhtin M. M. (2002) Problemy poetiki Dostoevskogo [Problems of Dostoevsky's poetics]. Moskva-Augsburg : «Im-Werden-Verlag», 2002, p. 72 (in Russian).

${ }^{74}$ Ibid, p. 72. 
the end of the year looks like the end of life... But it is perceived differently in March, when nature wakes up and manifests itself in colors, smells and sounds. Spring also awakens in the souls of people... and everyone prepared a mask of their ancestor ... But it was not only by clothes and a mask that they depicted forefathers, they also mentioned some customs or features of the deceased, their language, behavior ... a certain category of philistines turned this holiday into a parody, putting on whatever turns up, in particular, sometimes some ugly masks, made in haste ... Animals' and birds' heads... or snouts of some sort of fiends with bloody fangs prevailed among such masks"75.

At the same time, such masking can be considered in the context of Slavic rituals. For example, characterizing the tradition of dressing up for yuletide, A. Baiburin notes that "different groups of maskers are united by one common characteristic: they are all connected with the sphere of the $\mathrm{f}$ o e and opposed to the $\mathrm{f} \mathrm{r}$ i e $\mathrm{n} \mathrm{d}$ in all planes topical for the group: social (... farriers, soldiers), ethnic (Romas, Moors, Turks), belonging to nonhuman, animal sphere (bull, goat, bear, etc.), witchcraft (devil, evil spirits, etc.), the world of death (the dead, forefathers) and generally the distant land ("people of the road"). By the well-known analogy, the maskers exemplify a specific parade of representatives of an alien world",76.

During Morana holiday, all residents of Lviv temporarily turn into pseudomorphic characters: people feign the dead, representatives of the animal or supernatural worlds. Pseudomorphism transforms from the exception into the norm.

Everything stated above quite vividly manifests, on the one hand, the significance of pseudomorphic characters in Y. Vynnychuk's novel, and, on the other hand, the expediency of considering "The Pharmacist" in the broad context of cultural tradition.

\section{CONCLUSIONS}

Thus, it is obvious that cultural aspect of philological analysis is relevant and significant. The scrutiny of scientific works proves that the

75 Vynnychuk Y. (2015) Aptekar [The Pharmacist]. Kharkiv: Folio, pp. 257259 (in Ukrainian).

76 Baiburin A. K. (1993) Ritual v traditsyonnoj kulture. Strukturnosemanticheskij analis vostochoslavijanskikh obrjadov [Ritual in traditional culture. Structural and semantic analysis of East-slavic rites]. Sankt-Peterburg : Nauka, p. 132 (in Russian). 
pseudomorphic characters are among the phenomena that have a longterm potential for cultural study in the realm of philology. Such characters' main feature is their falsehood created by the violation of correspondence between their essence and their formal presentation/ reception (they acquire alien appearance, impersonate others, they are perceived inadequately). The means of creating pseudomorphism are travesty, reincarnation, verbal-positional pretense, situational mismatch (coincidence, confusion, etc.). Such images are associated with the expression of universal beliefs about the contradictions of the visible and the true, which in many forms is reflected in the cultures of many countries of the world.

There are different preudomorphic characters in "The Pharmacist" by Y. Vynnychuk: 1) Yuliana-Lorenzo (a girl who performs the role of a young man); 2) devil-Franz, who stays among people in human form; 3) self-proclaimed pharmacist Lukash, who pretends to be Martin (his deceased friend).

All the images naturally fit into the cultural context: as for the first character, it is connected with a cross-gender travesty of ancient rites, dissemination of this motif in folklore and literature (works by G. Boccaccio, Lope de Vega, T. de Molina, C. Goldoni, W. Shakespeare, etc.); as for the second one, it reflects the universal beliefs in the possibility of humanization of the supernatural creatures that are logically reflected in art in general and literature in particular (works by J. W. Goethe, J. Cazotte, A. von Chamisso, M. Gogol, L. Andreyev, M. Bulgakov and others); as for the third protagonist, it shows correlation with the phenomenon of imposture. Depiction of Morana's holiday is to be examined in the light of carnivalesque culture.

At the same time the pseudomorphic characters of the novel under study have their specific features: they are modernized and creatively transformed in accordance with the modern culture realia.

\section{SUMMARY}

The article deals with the study of correlation between the pseudomorphic characters of Y. Vynnychuk's novel "The Pharmacist" and the cultural tradition. The cultural aspect of philological analysis makes it possible to elucidate this issue. The main feature of pseudomorphic characters is the contradiction between their essence and formal presentation/reception (they impersonate others/are inadequately perceived). Several pseudomorphic images of the book are considered here. 
The first one is a girl Yuliana by name, who pretends to be a young man Lorenzo. The second image is that of the devil who hides behind the mask of a common human. The third pseudomorphic character is the pharmacist Lukash, who plays the role of Martin (his deceased friend). All the images naturally fit into the cultural context: as for the first character, it is connected with a cross-gender travesty of ancient rites, dissemination of this motif in folklore and literature; as for the second one, it reflects the universal beliefs in the possibility of humanization of the supernatural creatures that are logically reflected in art in general and literature in particular; as for the third protagonist, it shows correlation with the phenomenon of imposture. It is advisable to consider the images of Morana holiday, during which the inhabitants of the city hide behind the masks of their dead relatives or monsters, in the light of the carnivalesque cultural traditions. At the same time, the pseudomorphic characters of the novel under study have their own peculiarities: they are modernized and creatively transformed according to the realia of modern culture.

\section{REFERENCES}

1. Simbirtseva N. A. (2007) Bytije literaturnokhudozhestvennogo proizvedenija: kulturologicheskij aspect [Functioning of a work of fiction: culturological aspect]. Vestnik Chelyabinskogo gosudarstvennogo universiteta, no. 14. Pp. 28-34.

2. Betsenko T. (2017) Vydy analizu khudozhnoho tekstu [Types of a literary text analysis]. Visnyk Lvivskoho universytetu. Seriya filolohichna, vol. 64, ch II. Pp. 239-244.

3. Komarova L. I. Sovremennyje podhody $\mathrm{k}$ izucheniju hudozhestvennogo teksta [Modern approaches to studying a literary text]. Cyberleninka (electronic journal). Retrieved from: https://cyberleninka.ru/ article/n/sovremennye-podhody-k-izucheniyu-hudozhestvennogo-teksta (accessed: 24 January 2020).

4. Nikolova O. O. (2017) Psevdomorfni personazhi ukrainskoi ta rosiiskoi literatur kintsia XVIII - pershoyi polovyny XIX st. (u konteksti yevropeiskoyi tradytsii). [Pseudomorphic Characters of Ukrainian and Russian Literatures of the Late $18^{\text {th }}-1^{\text {st }}$ Half of the $19^{\text {th }} \mathrm{C}$. (in the Context of European Tradition)]. Zaporizhzhya : Zaporizkyi natsionalnyi universytet. 450 p. (in Ukrainian).

5. Osinovskaya O. S. Kross-gendernoje pereodevanije v pjesah U. Shekspira [Cross-gender change of attire in plays by W.Shakespeare]. Literatures and Languages (electronic journal), vol. 21. Retrieved from: 
http://svr-lit.ru/svr-lit/articles/english/osinovskaya-kross-gendernoe-pere odevanie.htm. (accessed: 31 January 2020).

6. Frazer J. G. (2001) Zolotaja vetv: issledovanije magii i religii $v$ dvuh tomah [Golden bough: a study of magic and religion in two volumes]. Moskva : TERRA - Knizhnyj klub, vol. 1.528 p. (in Russian).

7. Cornford F. M. The origin of Attic comedy. London : EDWARD ARNOLD, 1914. 252 p.

8. Bakhtin M. M. (1990) Tvorchestvo Fransua Rable $i$ narodnaya kultura Srednevekovya i Renessansa [The Creative Art of François Rabelais and Folk Culture of the Middle Ages and the Renaissance]. Moskva: Hudozhestvennaja literatura. 543 p. (in Russian).

9. Sazonovich I. P. (2011) Pesni o devushke-voine $i$ byliny o Stavre Godinoviche : issledovanije po istorii razvitija slavjano-russkogo eposa [Songs about a girl-warrior and epics about Stavr Godunovich]. Moskva : Kniga po Trebovaniju, 183 p. (in Russian).

10. Krzhizhanovskiy Y. (1963) Devushka-yunosha (k istorii motiva «peremena pola») [A girl-boy (history of the "gender change" motive)]. Russkij folklor, vol. 8. Pp. 56-66.

11. Uliura A. (2004) Henderno markyrovannoje pereodevanije kak komicheskoje (na materiale russkoj klassicheskoj literatury) [Gendermarked cross-dressing as the comic (case study: Russian classical literature)]. «Dóxa / DOKSA». Zbirnyk naukovykh prats z filosofii ta filolohii, vol. 5. Pp. 335-342.

12. Krokhmalnyi R. O. (2005) Metamorfoza i tekst: semantychna, strukturotvorcha $i$ svitohlyadna rol pereminy khudozhnoho obrazu [Metamorphosis and the text: semantic, structure-making and worldview role of changing a literary image]. Lviv : Vydavnychyi tsentr Lvivskoho nats. un-tu imeni Ivana Franka. 424 p. (in Ukrainian).

13. Makarenko Y. K. (2002) Zhanrovyj aspekt sjuzheta samozvanstva $v$ russkoy dramaturgii $i$ istoriografii kontsa XVIII - pervoj treti XIX $v v$. [The genre aspect of the plot about impostor in Russian dramaturgy and historiographics of the late XVIII - early XIX centuries] (PhD Thesis), Tomsk, $21 \mathrm{p}$.

14. Lazutkina M. G. (2003) Formirovanije hudozhestvennogo obraza samozvantsa Lzhedmitrija I v russkoj literature XVII - XIX vekov [Formation of a fictional image of the impostor Pseudo-Dmitrij I in Russian Literature of XVII - XIX centuries] (PhD Thesis), Moskva, 19 p.

15. Vitiak Y. (2016) Literaturna farmatsevtyka. Mizh panatseieiu i platsebo [Literary pharmaceuticals. Between the panacea and placebo]. Literaturnyi Ternopil, no 2, pp. 83-84. 
16. Kotsarev O. «Aptekar» Vynnychuka: vidmy, katuvannia, strashni mahichni knyzhky, balzamy, otruty i troshky seksu ["The Pharmacist" by Vynnychuk: witches, tortures, horrible magic books, balms, poisons and a little sex]. Тексти.org.иа [Texts.org.ua] (electronic journal). Retrieved from: http://texty.org.ua/pg/article/editorial/ read/63534/Aptekar_Vynnychuka_vidmy_katuvanna_strashni_magichni_ knyzhky (accessed 10 January 2020).

17. Litvinchuk T. V. (2017) Lokus domu v serednovichnomu Lvovi (na materiali romanu «Aptekar» Yuriia Vynnychuka) [Locus of home in medieval Lviv (Yurii Vynnychuk's "The Pharmacist": case study)]. Literaturoznavchi studii, vol. 1(2), pp. 32-40.

18. Panchenko A. (2016) Chytajem ukrainskoje: Retsenzija na knigu «Aptekar» Yurija Vinnichuka [Reading Ukrainian: review of the book "The Pharmacist" by Yurii Vynnychuk]. Segodnia [Today] (electronic journal). Retrieved from: https://ukr.segodnya.ua/lifestyle/ showbiz/chitaem-ukrainskoe-recenziya-na-knigu-aptekar-yuriya-vinnic huka-701314.html (accessed 20 December 2019).

19. Tsikhotskii I., Borosovska I. (2018) Starolvivska beletrystyka Yuriia Vynnychuka: avtorska kontseptsiya movnoho istoryzmu (na materiali romanu «Aptekar») [Old-Lviv belles-lettres by Yurii Vynnychuk: author's concept of language historicism (novel "The Pharmacists": case study)]. Visnyk Lvivskoho universytetu. Seriya filolohichna, vol. 68, pp. 30-47.

20. Cherniuk S. L. (2016) Komunikatsiina ryzomatyka romanu Y. Vynnychuka «Aptekar» [Communication rhizomatics of Yurii Vynnychuk's novel "The Pharmacist"]. Nuakovi pratsi Chornomorskogo derzhavnoho universytetu imeni Petra Mohyly kompleksu "KyevoMohylianska Akademiia”, vol. 276, no. 264, pp. 121-126. Retrieved from: http://nbuv.gov.ua/UJRN/Npchdufl_2016_276_264_23 (accessed 11 November 2019).

21. Vynnychuk Y. (2015) Aptekar [The Pharmacist]. Kharkiv: Folio, 318 p. (in Ukrainian).

22. Propp V. Y. (2000) Russkije agrarnyje prazdniki. Opyt istoriko-etnograficheskogo issledovanija [Russian agrarian holidays. Experience of historical and ethnographic research]. Moskva : Labirint, 192 p. (in Russian).

23. Freidenberg O. M. (1997) Poetika sjuzheta $i$ zhanra [Poetics of plot and genre]. Moskva : Labirint, 448 p. (in Russian). 
24. Miller O. F. (1869) Ilja Muromets $i$ bogatyrstvo Kijevskoje [Ilya Muromets and Kyiv bogatyrs]. Sankt-Peterburg : Tipografija N. N. Mikhajlova, 830 p. (in Russian).

25. Franko I. (1984) Divchyna-voiachka [A girl-warrior]. Zibrannia tvoriv u 50-ty $t$. [Collection of works in 50 volumes]. Kyiv : Naukova dumka, vol. 42, pp. 225-229.

26. Meletinskiy Ye. (1990) Istoricheskaja poetika novelly [Historical poetics of novella]. Moskva: Nauka, 278 p. (in Russian).

27. Veselovsky A. N. (1870) Starinnyj teatr v Yevrope [Ancient theatre in Europe]. Moskva : V tipografii P. Bakhmeteva, 419 p. (in Russian).

28. Anikst A. (1989) Dvenadtsataya noch, ili Chto ugodno [Twelfth Night or What you will]. Angliyskaya komediya XVII XVIII vekov : antologiya [English comedy of 17th-18th centuries]. Moskva: Vysshaya shkola, pp. 735 - 746.

29. Andreyev M. L., Khlodovskiy R. I. (1988) Italyanskaya literatura zrelogo i pozdnego Vozrozhdeniya [Italian literature of high and late Renaissance]. Moskva : Nauka, 296 p. (in Russian).

30. Shchytova-Romanchuk L. A. (2000) Tvorchist Hodvina v konteksti romantychnoho demonizmu [Godwin's creative activity in the context of romantic demonism] (PhD Thesis), Dnipropetrovsk: DDU, $20 \mathrm{p}$.

31. Propp V. Y. (1946) Istoricheskije korni volshebnoj skazki [Historical roots of a Fairy-tale]. Leningrad : Izd-vo Leningradskogo gosudarstvennogo ordena Lenina universiteta, 337 p. (in Russian).

32. Mednikova M. B. (2004) Fenomen maski v traditsionnoj kulture: simvolicheskaja priroda sposoba ritualnogo prevrashchenija [Phenomenon of a mask in traditional culture: symbolic character of the way of ritual metamorphosis]. Livejournal. (electronic journal). Retrieved from: https://svart-ulfr.livejournal.com/207940.html (accessed 12 January 2020).

33. Gennep Arnold van. (2002) Obrjady perehoda: Sistema izuchenija obrjadov [Rituals of transition: system of studying the rituals]. Moskva : «Vostochnaja literatura» RAN, 198 p. (in Russian).

34. Bakhtin M. M. (2002) Problemy poetiki Dostoevskogo [Problems of Dostoevsky's poetics]. Moskva-Augsburg : «Im-WerdenVerlag», 2002, 167 p. (in Russian).

35. Baiburin A. K. (1993) Ritual v traditsyonnoj kulture. Strukturno-semanticheskij analis vostochoslavijanskikh obrjadov [Ritual 
in traditional culture. Structural and semantic analysis of East-slavic rites]. Sankt-Peterburg : Nauka, 240 p. (in Russian).

Information about the authors:

Oleksandra Nikolova,

Doctor of Philology, Associate Professor (Dotcent), Professor at the Chair of German Philology and Translation, Zaporizhzhia National University 66, Zhukovski str., Zaporizhzhia, 69600, Ukraine ORCID ID: orcid.org/0000-0002-2327-1941

Kateryna Vasylyna, Candidate of Philology, Associate Professor (Dotcent), Associate Professor at the Chair of English Philology,

Zaporizhzhia National University

66, Zhukovski str., Zaporizhzhia, 69600, Ukraine ORCID ID: orcid.org/0000-0002-7885-5418 


\section{SUPERSTRUCTURE AND HEGEMONY IN MILAN KUNDERA'S "THE JOKE" AND POST-POSTMODERN CULTURAL TEXTS}

\section{Oksana Prihodko}

\section{INTRODUCTION}

In the novel "The Joke" ("Žert", 1967), Milan Kundera demonstrates the mechanism of functioning of the superstructure. Under this concept, which was first developed by Louis Althusser, I mean a set of factors that influence society, forming certain hegemony and defining the system of power relations. From the very beginning, the novel's character Ludvik Jahn is reluctant to return to his hometown, the center of which he roamed in childhood and adolescence. In the end, the character confesses that it is not just reluctance, but a hatred that causes this psychological discomfort associated with the perception of the past.

The motif of superstructure corresponds to the motif of cultural transgression and transculturalism discourse in general in contemporary literature and cinema texts of the post-postmodern period. The scholars admit that

The Hegelian contradiction is never overdetermined. Therein lies the difference between Hegel and Marx and between economism and Althusser's reading of Marx. The contradiction between forces and relations of productions cannot explain historical change on its own. It only acquires ruptural force through its overdetermination by contradictions arising in different levels of the social formation. Instead of a direct causal link between base and superstructure, which conceives of politics and ideology as epiphenomena or by-products of the economy, the superstructures acquire their own specificity and effectiveness in the historical process, to the extent that changes in the base do not automatically modify the superstructures (Althusser, 1969, pp. 111, 115). The latter are part of the conditions of existence of the economic level, if only because labour legislation intervenes to organise the process of production (Althusser and Balibar, 1970, p. 178). The superstructures always already contaminate the base ${ }^{1}$.

\footnotetext{
${ }^{1}$ https://www.researchgate.net/publication/262358457_Althusser, p. 189.
} 
As Dmytro Drozdovskyi argues, "In post-postmodernism, the psychological aspect of reality is evident. Functions of the psyche are a resource that makes it possible to combine the real and the imaginary. Post-postmodernistic reality appears as a type of space in which the penetration of the fictitious into the present and vice versa takes place, and the subject of reality cannot fully understand what, in fact, occurs",2. The author states continuing his theory of post-postmodernism that "Postpostmodernistic reality is created in a special way and at the same time appears to be split and potentially multiple. In post-postmodernism, the motif of the fragmented person and, as a consequence, the perception of reality as a bifurcated phenomenon (Atonement by I. McEwan) has been actualized. Besides, the constructed schizophrenic reality sometimes appears to be the last opportunity to protect from the Truth, which person cannot perceive due to the biological limitation of his own analytical abilities (Saturday by I. McEwan). Heroes feel at the intuitive level that there is something more complicated in the organization of the body, memory, brain, the universe but at the moment they do not have adequate tools for understanding these phenomena and their description for future generations (D. Mitchell's Cloud Atlas)"”3.

Discourse and motives of cultural transgression are represented in the contemporary American cinema culture and texts of the XXI Century.

For example, recent Hollywood films demonstrate the tendency of American culture to reveal the idea of multicultural and transcultural representation of the ordinary life of the characters who exploit mimetically the life of ordinary people. This idea of mixture of different people of different nations and races is depicted, for example, from the first episodes in the movie "The Good Doctor", which represents a story about the doctor with autism disorder. In the film, we see actors of Mexican, Chinese and white American origin. This is an example of transculturally oriented Hollywood films accepted and appreciated by people of all nations and all races in different countries. The idea of global/globalized village is represented in the mentioned film in which the situations and collisions happen in a local American hospital in $\mathrm{St}$ Bonaventura.

${ }^{2}$ Drozdovskyi, D. (2019). Philosophical and Genological Features of English Post-postomodernistic Novel: Typological Characteristics. English and American Studies, 1 (16), p.

${ }^{3}$ Ibid. P. 152. 
Let me remind you about another film that is based on the Sherlock Holmes discourse. In the American movie "Elementary", you see Mr. John Watson transformed into Joan Watson, a woman of a Chinese origin. In addition, Sherlock is not a British (originally Scottish) character but a person who belongs to the American mafia family (his father is a big boss) and who lives in New York and becomes an outstanding police consultant. This movie also represents the idea of the place with people of different origin.

\section{Superstructure and Czechoslovakian Society in "The Joke"}

The scholars who investigate the novel "The Joke" outline that this text has been variously labeled as realistic, political, ideological, and psychological in genre by different reviewers. Justifications for such categorizations seem quite equally available. The author's outstanding style of narration with its four first-person narrators and their internal monologues, as Craig Cravens (2000) suggests, are enough evidence to register this multi-perspectival novel as a psychological one. He believes that "such a narrative method has come to be associated with the type of novel known as the "psychological novel," practitioners of which such as Faulkner, Woolf, Beckett and Joyce, often employ multiple perspectives to assert the subjective nature of experience and thus display human consciousness as isolated, unique and idiosyncratic." However, these techniques of multiple narration, polyphonic composition and fascination with numbers (especially number 7) are what most readers and reviewers have noticeably lingered upon as structural devices in this novel. ${ }^{4}$

In the Neo-Marxist theory provided by L. Althusser, there is a concept of superstructure. Yu. Pavlenko, a Ukrainian scholar, points out that "Althusser views ideology as part of a superstructure that legitimizes substructures, that is built in economic and social relations. Althusser denies the possibility of scientific ideology, which was mentioned, in particular, by Vladimir Lenin, because ideology and science are based on different epistemological bases and are connected with different social practices. The questions of truth or error do not relate to ideology, because it establishes a set of norms that orient individuals to a particular relation to the world and the society in which it lives. That is, ideology is a separate system by which people perceive, evaluate, "experience",

${ }^{4}$ Masoomi M. (2012). Narration in Milan Kundera's The Joke. Academic Research International Vol. 3, No. 1, July 2012, p. 100. 
perceptions that have formed in them, relative to the real conditions of existence. Moreover, this system of representations may consist of concepts, ideas, myths, and images" "Liu Kang argues that Maoism is a critical resource in Althusser's inquiries into the problems of superstructural elements such as culture, ideology and politics, in his search for an alternative modernity",

Exploring different concepts of discourse (as a factor of ideology), $\mathrm{Yu}$. Pavlenko concludes that "the further development of the concept of political discourse is found in Laclau and Mouff: discourse is the primary space that constitutes social reality as such in a society devoid of ontological. The totality of hegemony is a complex game with empty meanings, which is ascribed universal meaning. This principle of "lack" is interpreted according to Lacan as "lack of Being", so that ultimately the discourse through constructing social differences and attributing content to them performs an ontological function, acting as a substitute for being",

Analyzing the approaches of Marxist criticism, Peter Barry points out that the focus of this interpretation practice is on the analysis of the material world, since Marxism itself is the antithesis of the philosophy of idealism.

The past in M. Kundera's novel represents the efforts of the new authorities to build socialism in Czechoslovakia, but the path to socialism lay through forms of totalitarian control over society. Masoomi M argues that in the novel

the action of the novel centers on the story of Ludvik, the protagonist, who comes from a small town in southern Moravia and who becomes a fervent political activist during his university days in Prague. He tells how the joke of the title - a postcard (Optimism is the opium of

${ }^{5}$ Pavlenko Yu. (2010). Anthropological dimensions of ideology. Thesis for a Candidate of Science Degree in Philosophy. 09.00.04 - Philosophical Anthropology, Philosophy of Culture. M. Drahomanov's National Pedagogical University. Kyiv, p. 13 .

${ }^{6}$ Yan, F. (2018). “The 'Althusser-Mao': Problematic and the Reconstruction of Historical Materialism: Maoism, China and Althusser on Ideology": Comparative Literature and Culture 20. 3: URL: https://docs.lib.purdue.edu/cgi/viewcontent.cgi? article $=3258 \&$ context $=$ clcweb, p. 2

${ }^{7}$ Pavlenko Yu. (2010). Anthropological dimensions of ideology. Thesis for a Candidate of Science Degree in Philosophy. 09.00.04 - Philosophical Anthropology, Philosophy of Culture. M. Drahomanov's National Pedagogical University. Kyiv, p. 16. 
the people! A healthy atmosphere stinks of stupidity! Long live Trotsky!) to a naïve yet exasperatingly patriotic girlfriend, named Marketa, whom he was trying to impress - leads to his expulsion from the party and university, army service among the politically unwanted and several years in the mines of Ostrava, where he also experiences a tragic love affair with Lucie. Later Ludvik plans to revenge on Pavel Zemanek, his former party comrade who played a crucial role on his ill-fated life. Ludvik tries to seduce Zemanek's wife, Helena, during her visit to Moravia as a radio reporter. But this turns out to be another joke on Ludvik himself, since he learns that Zemanek himself wants to get rid of Helena. Ludvik succeeds in his revenge plan, on the surface, but this does not make him victorious; the story ends in Helena's suicide attempt and Jaroslav's heart attack ${ }^{8}$.

Control is explicated in the novel in situations of remembering a student's past, when Helena Zemánková is called in for questioning to find out what Ludvik wrote to her in a postcard. The peculiarity of the situation is that the "institute of power" already knows everything that is written in the postcard, but nevertheless there is pressure on the student, who eventually decides for a while to move away from an unreliable according to the System (Institution of Power) views friend Ludvik. Another student is also summoned to party meetings and given a preventative talk about moral standards and rules of conduct in a socialist society.

The society of Czechoslovakia in the past is a panoptic, using the metaphorical and eloquent image provided by Michel Foucault. This panoptical system establishes forms of total control over everything, and clearly defines the norms of ethics and morality, the departure from which will signify the failure of the builder of communism or socialism. Such influences actualize the idea of a superstructure when an individual is exerted by cumulative influence from different sides so that he or she adopts the pattern of behavior and constructs the type of identity requited by the System. Studying at university is in no way a form of freedom and self-discovery in "The Joke", but of constant fears. Helena returns to normal communication with her friend only after the permission from the System. That is, the private in the novel is entirely dependent on ideology and the system of power relations that seek to control the personal level of

${ }^{8}$ Masoomi M. (2012). Narration in Milan Kundera's The Joke. Academic Research International Vol. 3, No. 1, July 2012, p. 100. 
communication. As a consequence, there are injuries, the desire for the character to renounce the past and escape from it.

The past is associated with the protagonist with control, freedom, and pain. Although the character ironically points out that today there is an excess of another type in the world, when freedom has become too much obsessive and everything is allowed, but the past is also marked for him negatively. He is afraid of meeting others because they will force Ludvik to discover those memory cavities that the hero of the novel wants to hide and never return to them. "Superstructure denotes the result that is the consequence of a set of causes, that is, the interaction of several, not one, factor (in this case economic). The idea of totality and interaction of causes is aimed at refuting a simplified understanding of the directly proportional relationship between base and superstructure". "This also includes the concept of relative autonomy, which demonstrates that, despite the links between culture and the economy, art is to some extent independent of economic forces" $"$.

The latter statement is criticized in the novel, more precisely criticized for trying to turn the university and social life into an instrument of ideology.

"Althusser makes an important distinction between what can be called state power and state control. State power is exercised by the socalled repressive structures"11. "However, the state also exercises its power in a more veiled manner, allegedly defending internal harmony in society and using what Althusser calls ideological structures or a state ideological apparatus. These include institutions such as political parties, schools, the media, the church, the family, and the arts (including literature), which fuse ideology - a set of ideas and positions that are in the interests of the state and the political system", 12 .

\section{Ideology and Homelessness}

M. Kundera's novel underlines the motive of homelessness and abandonment. The friend whom Ludvik once helped now gives his accommodation in order to help his old friend to have the dreamy

9 Barry P. (2008). Introduction to Theory: Literary Studies and Cultural Studies; [trans. into Ukrainian from English by O. Pohynaiko]. Kyiv: Smoloskyp, p. 194.

\footnotetext{
${ }^{10}$ Ibid. P. 194.

${ }^{11}$ Ibid. P. 195.

12 Ibid. P. 196.
} 
enjoyment on a normal bed (the hotel room bed is awful). The idea of moving, finding yourself outside the world in which you were born is a key one in the novel. The displacements are conditioned by the rejection of the home, which is dominated by control and dictatorship. A situation in which someone has access to your private correspondence can be qualified precisely with the help of the concept of dictatorship, which describes the state of total control of society by the authorities (institutes of power). The past is associated in the novel with military fighting, protests and competitions, and in one episode, the narrator says that the lands of southern Moravia have always been a kind of outpost, from the Hungarians and other conquerors.

In "The Joke", the motif of the "accursed land" and at the same time "lost land" that no longer belongs to the hero (Ludvik) who is good at fleeing the home place is explicitly explained. The concept of the home in the novel is like a hell, and there is even greater contrast to the title. The past is a dictatorship that is traumatic and at the same times a joke, because everything that happened to the hero of the novel was unnatural, contrary to human nature, for which one of the possibilities for selfrealization is freedom. However, under the influence of ideology and the presence of hegemony in the Czechoslovak world, freedom becomes a simulacrum, the true understanding of which is unrecognized by the inhabitants of that world.

Ludvik (he is one of four narrators: Ludvik, Helena, Kostka, and Jaroslav) has a deep understanding of freedom when he, having spent days, months and years in migration around other unknown places, in numerous hotels, realizes what the cult of the key means: when you are the owner of your own space that no one can fall into anymore. This episode in the novel seems to me semiotically meaningful and a key one: having acquired the key at the reception, the hero finds himself the owner of his own world, in which the source of pain and trauma belongs only to his own past, which also needs to be learned to manage. Further, having gained freedom, Ludvik already lacks freedom only as a potentiality of opportunity: he seeks to build space around him as being cozy and comfortable.

Hence, the image of the bed in the room and the table, which can accommodate only one person, is a central one. Ludvik tries to slide the table to the bed to try to see at least two can sit around that table, but that idea fails. The bed is too low; it looks like a hammock or even a pit into which the protagonist falls. The image of the pit is not accidental in the text: before us the metaphor of the grave and the bed is not a resting place, 
but a coffin, a grave for the hero of "The Joke". Ludvik, on the contrary, does not seek to die, but is ready to meet his own past, which he suddenly crosses in a hairdresser while shaving. The motive of transforming the space of death into the space of life unfolds before the reader of the novel. Realizing the essence of freedom, the character of the novel seeks not only to use freedom as an abstraction, but to form a free life. Freedom means comfort and opportunity to enjoy, which is unacceptable to the communist socialist society full of militaries in Czechoslovakia, where the protagonist lived in the past.

\section{Hollywood as a Displacement of Cultural Hierarchies}

In this chapter of the research, I will try to represent the key idea of the hybridity associated with the contemporary Hollywood discourse, which remains too little with the American film industry if 1940-s and 1950-s when Vivien Lee and M. Brando were the starts of the American Hollywood playing in Tennessee William's "A Streetcar Named Desire". In addition, I have mentioned this outstanding film to spotlight the idea represented in T. William's original play and associated with S. Kowalski and Blanche, who is an American aristocrat woman. Stanley is a representation of the new Americans who come from other worlds but who bring the idea of new vitality, new transgression, new brutal sexuality, and new values. T. Williams demonstrates the idea of loss of the old American fundamental ground associated with Blanche's aristocratic family and her cultural values. Stanley is reckless, rude, brutal hut he is a symbol of new America based not on the concept of aristocratic values but on the idea of melting pot, of the idea that each person can get his or her benefit and move up the on social lift.

By the end of the First World War, the American film industry dominated not only the domestic market in the United States but also the movie marketplace throughout much of the world. It presented images of American society and nationhood not only to Americans themselves, but also to countless millions of foreigners who were frequently entranced by the skill and professionalism of American films. Hollywood became the great "dream factory" and one of the most seductive dreams it spun was the dream of a particularly American form of national community ${ }^{13}$.

13 Stokes Melvyn, Sipière Dominique (2010). Out of Many, One: European film-makers construct the United States, European journal of American studies [Online], 5-4. URL: http://journals.openedition.org/ejas/8650 (accessed on January 15, 2020). 
This is what we can see now in Hollywood industry based on the idea of co-production between different world industries reinforced in one Hollywood project. Moreover, it reveals the idea of hybridity sometimes based on exploiting cultural stereotypes. Hollywood films incorporate various prejudices known around the world in association with different cultures and countries (e.g. Americans eat too much hot dogs and hamburgers with cola, they are reckless and don't care about clothes to wear, etc.; European people are more conservative and aristocratic, they are trying to study the classic arts of the Greek and Roman periods; etc.). Even each country has its world stereotype (Italians are good singers; French are falling in love; British are rational, Americans are pragmatic, etc.). Hollywood film industry of the present days is trying into to unite all these cultural stereotypes and produce a narrative based on this mixture of different prejudices. Hollywood develops the idea of Benedict Anderson about the nations as "imagined communities." They are brought together by a common sense of shared identity and values, together with a perception that - transcending all groups, regions and classes - there is a sense of social cohesion ${ }^{14}$.

That is why some critics consider Hollywood films much easier than, for example, traditional European or Japanese, Polish or Ukrainian or other films. Hollywood industry deals with the typical scenes, problems, emotions understandable in all cultural zones. In addition, this causes in some professional film circles a special attitude to Hollywood industry as a kind of McDonald phenomenon: you are recognized everywhere but you do not have your national peculiarities. I read a Ukrainian magazine "Kino-Theater" ("Film-Theater") with a discussion about Hollywood films that were perceived by the film industry experts as a kind of intellectual or cultural junk food. Junk Hollywood industry is well known but it is not healthy as it does not provide the national specification of the people of various zones on the planet but demonstrates the idea of the globalized village (by Marshall McLuhan) of people. When you watch Hollywood films like "Avatar", "Lovely Bones", or something like this, you see the love story represented even in the postapocalyptic time or on another planet.

Therefore, Hollywood reinforces and exploits world known and world appreciated scenarios based on common emotional reactions and responses. Hence, Hollywood is criticized for being too understandable

${ }^{14}$ Ibid. 
and not sophisticated or thought-provoking. Hollywood films often appeal to common world emotions and represent the same situations that can be characterized using again well-known Hollywood images of Terminator, Rambo (a hero who saves the planet and the entire world), etc. On the other hand, we have a beautiful woman who reveals the love story, which is obvious for Hollywood industry. The female-character is structured to love a "beast" and have an impact on the male-character. Hollywood films for children more effectively demonstrate this tendency of using world recognizable plots (stories) that have human archetypes.

In this way, Hollywood can be criticized as an industry with no roots. Moreover, Hollywood now is like a simulacrum. However, the grounds for this tendency can be found even in 1960-s when Hollywood directors had a special map of zones in California that can be used for filmmaking about different places on the planet. I mean that if, for example, you needed the Himalayas for your film, you had to go to north California and direct a film there; if you needed the Cordilleras, you had to go to another place in the same state. This example provides that idea of simulacrum, and now Hollywood is considered of a kind of representation of world simulacrum. Using this term I mean that Hollywood can create the atmosphere of potentially any place on the planet or in the Universe.

Furthermore, I want to concentrate your attention on the idea that Hollywood co-production creates cultural spheres that represent the world in which we have an ideal harmony of different people taking into account their age, sex, gender, color of skin, etc. Hollywood co-production is as a simulacra based on the representation of the ideal politics that is not easy to achieve in the real life. Anyway, Hollywood films now are based on the co-production principles between different countries, and in the films we should obviously see actors of all races and various ages. The anti-ageism concept is becoming more actively represented in the contemporary Hollywood films in which old men or women retell their personal stories with flashbacks to the past. Thus, we see in the films not only actresses and actors with like-top-model bodies but actresses and actors of different ages and with different bodies. For example, you can see this in the movie "The Hustle" that appeared last year and it deals with some European and American stereotypes which touch also the sphere of personal body. Penny Rust (Rebel Wilson) in "The Hustle" is a woman with extra weight but her behavior in the film is supposed to demonstrate the typical behavior of the American people: reckless and innovative, money concerned and self-oriented. 
Penny is a small-time con artist who traps men into giving her money, whereas Josephine is a sophisticated con artist who cons the world's richest men out of their money, whose idol is the legendary unknown con artist "Medusa". The two con artists meet on their way to the French Riviera for the first time. Not willing to take any chance with any competition, Josephine has Penny is "arrested", after which Josephine pays her bail and advises Penny to leave the country. Penny discovers that she was conned by Josephine but begs her to teach Penny her ways. Josephine and Penny execute a complicated con act against multiple rich men called the Lord of the Rings, stealing engagement rings. The plan works at the beginning, but after a while, Josephine refuses to pay Penny because she's an apprentice. Penny and Josephine wager Penny's entire networth of $\$ 500,000$ using billionaire Thomas Westerburg, the creator of a tech app called YaBurnt, as their victim ${ }^{15}$.

Contemporary American films about the characters who travel to Europe demonstrate the features that help to revise critically the American identity mainly created and shared by media and mass culture. I mean the views of Americans as courageous people ready to travel abroad and ready to overcome all the troubles on their way. However, they can do this because people can eat practically everything as Macdonald's cuisine is not unique and is based on very simple ingredients, etc. US people are ready to sit into the plane and fly for better life. They have the advantageous spirit and they know that money can talk and money are the same stimulus despite the country national currency.

These are the main stereotypes about the American people I the movies. People from the USA are ready to revive in the most difficult life situations because they were brought up in the circumstances that determined their eagerness to struggle for victory. To the contrary, European people are displayed in such films as more naive and more aristocratic. They have money and invest them not in traveling to unknown worlds and extreme destinations but in visiting Monaco expositions or playing in the casinos. These people are more naive and less courageous. They are ready to help people in difficult situation that is why cunning Americans who travel to world famous resorts as in the film can manipulate them.

In "The Hustle", for example, the girl from the USA Penny represents a type of gangsters who are brilliant manipulators and who are

15 Ibid. 
ready for everything to get money. European people can also have illegal income, they can belong to mafia but they are not so innovative thinking and fearless as Americans. In the film about two criminal women, we see that the younger one can eat everything even the shit not to be caught by the police and to get the aim. This metaphorical image is persuadably demonstrated when Penny is being feed by Josephine Chesterfield (Anne Hathaway), a more sophisticated gangster woman. Europe is represented in the movie as a land of big money. The Americans are the new power that needs that money. However, in this seeking of money and this play of life the Americans understand the real values of true humanism and they understand that money is just the instrument. The dangerous traveling give even cunning characters a way to understand themselves and understand the real value of life in a humanistic paradigm. Americans are described as open minded and even extra open minded to the world adventures. European people are more bohemian but their cultivation of arts is sometimes a ritual. However, this identity is displayed as false and not true.

Traditionally Hollywood film production considered to be opposite to the European cinema. This opposition was based on the principles of film distribution: Hollywood was oriented toward popular success and the income received after the film release was considered an important factor of film industry success. For example, The Star Wars was one of the most successful films in the history of the XX Century taking into account this criterion. The European film industry was perceived (and also appreciated) by the film experts as an industry oriented toward the formation of the films that provided ideas, philosophy of social action through images and various experiments, and generally revealed the philosophical aspects of live that is unique in each situation and for each person.

Let me remind the films with great European actors as Marcello Mastroianni, Jean-Paul Belmondo or Catharine Deneuve. The movies with these actors and actresses illuminated the idea of love as an omnipotent power despite the difficult social confrontations and psychological contradictions. Filmgoers became the fans of these actors who created the characters very close to real life problems but as real masters performed stories that represented a confrontation of a human being and reality. Even these actors are associated with the success of the European film industry (they became the symbols of the European cinema of the XX Century). These cinema products demonstrated true human 
emotions and difficult life collisions and misfortunes that can be overcome by strong personalities with strong true feelings and emotions.

The phenomenon of film identities was changed completely: these days both in European and American films, we see the actors of different countries who world for the film industry as the international industry that does not follow the old national traditions and principles. Hybridization is a result of a new philosophy that underlines the principle of cultural benefits that can be reached in the cooperation between various schools of film industry actors, directors, staff, etc. Cultural hybridization and transculturalism determine the specifics of the contemporary film industry. These notions relate to the new principles of creating cultural products that are produced on the transnational scale and are not oriented toward some ethnical and national specifics. Films are co-productions as "Cold Blood" or "Value of truth" (about Gareth Jones).

My second point to discuss Hollywood industry as an opposition (I am trying to state this this principle does not work for the XXI Century) to the European films relates to the idea that Hollywood was oriented toward the mass cultural success and strategies and European films tended to be more sophisticated and aristocratic for the filmgoers. I mean that many European films represented the special atmosphere of, for example, Paris or Rome with the accent to the history and architecture of these places that determine this special part of the world. The films revealed a unique artistic and bohemian aura that covered the psychological aspects of the characters in the movies. However, this tendency is not represented in the contemporary European films. Using the notion "European films" I mean those that involve European directs, staff or those that demonstrate the European cities paying attention to their architecture.

European films are grounded in the history facets but this aspect can be incorporated in the contemporary Hollywood films also and be just its part. Let us remind the movie "Hannibal" released a few years ago when in the third episode, Lector escaped to Europe and the scene of the movie was displaced from the States to Venice, Italy. The third part is associated mostly with some psychedelic aspect of the film narration. This transformation of the film narration I guess is also determined by the new landscape that appeared in the third episode. The third part of the movie reveals the traditional European fleur that now is integrated to the American films based according to the Hollywood principles.

Hollywood (the same as the US) represents the idea of the melting pot and deconstructs the idea of mono-ethnical phenomena. On the Hollywood industry, decorations could be created to produce the idea that 
the scene takes place on the ship or in Antarctica, or elsewhere. Contemporary American films mainly demonstrate the same architecture landscapes and urban design of high scrappers and business centers of New York or Los Angeles if the scene happens outside. The postmodern culture displaced the opposition between high art and low art. Derrida, Foucault, and Baudrillard deconstructed the idea that there is a significant difference of an opposition between mass/popular culture and classical high culture (Shakespeare was popular in his times but became the center of the Western Canon in Harold Bloom's theory).

\section{CONCLUSIONS}

Thus, Milan Kundera's novel "The Joke" represents the mechanism of the influence of superstructure as a set of different forces on the individual that determine his or her behavior and social models. It is demonstrated how the hegemony in society shapes the space of nonfreedom around Ludvik, how the power structures seek to control the private space defining ethical and moral boundaries for the inhabitants of the socialist world, which, however, still need to be built.

The past is, in fact, a desire to embody a future that has never come. Building socialism is a reminiscent of utopia, the path to nowhere that ends in flight with no final point. The native home, its own space in which childhood and adolescence took place, is not safe, and, therefore, determines the motive for escaping from the home place to unknown other worlds, because in fact, the socialist system did not allow people to have a private space and freedom of self-realization having an impact on their minds and mental patters.

To conclude, I want to draw your attention to the fact the transgression, cultural movement through the borders and boundaries is an important part of the contemporary Hollywood films. In this way, I follow and share the position of those critics and cultural experts/thinkers who say that Hollywood is a multifaceted and multicultural sphere of international co-production. National identity as a phenomenon does not exist in the American film industry. We can enjoy the peculiarities of various identities (Mexican, Chinese, Polish, etc.) in Hollywood film when they have a cooperation with others or when they are represented in a transgressed situation. Sometimes the directors use the typical stereotypes to criticize such behavior and to spotlight the differences that may cause problems and collisions. European people do not understand this ability of Americans to do all possible to get the aim for example. The co-productions industry unfolds the anti-sexist and anti-gender protocols 
that are the essential part of this business. Hollywood is oriented toward uniting all people of all nations in the common emotions. Moreover, it does not matter whether the situations in the movies are located in the US, in Europe or on another planet. People who watch the films in the cinemas should demonstrate the same ideas based on tolerance, peaceful coexistence, sharing love and support, etc. In this way, Hollywood reveals the idea that culture can support in the politics of uniting people on the planet in order to build a "globalized village". Contemporary Hollywood movies are oriented toward supporting and implementing through this art the idea of cultural hybridity and transculturation that is an Important part of building a peaceful planet on which people support each other for example in such disasters as the one happened in Australia in the end of December 2019 in early January 2020.

Moreover, I would like to summarize that these days in the film industry we have the result of the philosophical implications that had an impact on the hybridity of film and resulted in the lack of difference between American and European films as mass/"aristocratic". Latter can be the result of some snobbish cultural prejudices that do not have an impact on the world cultural market today. Global film scale exists in the hybrid forms and according to the principles of transculturation resulted in the film industry in the form of co-productions and cultural mixtures in which all-cultural differences are smashed and dotted.

\section{SUMMARY}

In the paper, the author has analyzed the theories and methodology of Marxist criticism related to the issues of hegemony by Louis Althusser. In the Neo-Marxist theory there is represented also a concept of superstructure. The methods exploited by Althusser outline the specific of representation of the "alien" as "my own" loci in M. Kundera's novel "The Joke", in which Prague has been depicted as a special space that is comfortable (well-known) and dangerous at the same time for the narrator. M. Kundera creates a space with double architecture: one level of this phenomenon represents the atmosphere of what reveals true emotions, expressions and feelings; however, the second level of this space contains unexpected dangers and is traumatic as it relates to the dimension of control and Soviet (KGB) power institutes. Besides, the author has developed the ideas of hegemony and discussed their representation in contemporary post-postmodern cultural texts of the film industry. The conception about post-postmodernism by D. Drozdovskyi has been discussed and unfold in the research. M. Kundera in a specific 
way exploits the idea of hybridity (cultural, memory, etc.). The concept of hybridity is highly essential for post-postmodern cultural texts. For the development of the presented ideas the author has chosen the representation of the transculturation issues in the contemporary American (Hollywood) film "The Hustle" that engages cultural stereotypes and represents a post-postmodern narrative based on the ideas of cultural hybridity as a phenomenon that can provide extra benefits for the cultural consumers. Moreover, the author concludes that the Hollywood industry now is a kind of implicit politics of destroying the differences that avoid the concept of sharing values because of cultural prejudices and oppositions. I share, however, the idea that Hollywood after exploits typical scenarios and simple clichés in the movies, but for the now it is a possibility to create cultural products based on the idea of co-production that will maintain the concept of peaceful co-existence through viewing the peoples of various color of skin and religious beliefs in the movies. Hollywood is a part of the global strategy based on the idea of creating a planet life free of terrorism as what states Henry Perowne in Ian McEwan's novel "Saturday". The contemporary cultural discourse exploits the paradigm of neo-Marxist criticism and the conception of superstructure and hegemony, however, these concepts are oriented toward the creation of the benefit by destroying and deconstructing cultural stereotypes used, for example, in American Hollywood film industry.

\section{REFERENCES}

1. Barry P. (2008). Introduction to Theory: Literary Studies and Cultural Studies; [trans. into Ukrainian from English by O. Pohynaiko]. Kyiv: Smoloskyp. 360 p.

2. Drozdovskyi, D. (2019). Philosophical and Genological Features of English Post-postomodernistic Novel: Typological Characteristics. English and American Studies, 1 (16). P. 150-159. DOI $10.15421 / 381921$.

3. Kundera M. (1969). The Joke: A Novel: English translation. New York: Coward-McCann.

4. Masoomi M. (2012). Narration in Milan Kundera's The Joke. Academic Research International Vol. 3, No. 1, July 2012. P. 100-105.

5. Pavlenko Yu. (2010). Anthropological dimensions of ideology. Thesis for a Candidate of Science Degree in Philosophy. 09.00.04 Philosophical Anthropology, Philosophy of Culture. M. Drahomanov's National Pedagogical University. Kyiv. 20 p. 
6. Stokes Melvyn, Sipière Dominique (2010). Out of Many, One: European film-makers construct the United States, European journal of American studies [Online], 5-4. URL: http://journals.openedition.org/ ejas/8650 (accessed on January 15, 2020).

7. Yan, Fang (2018). "The 'Althusser-Mao': Problematic and the Reconstruction of Historical Materialism: Maoism, China and Althusser on Ideology": Comparative Literature and Culture 20. 3: URL: https://docs.lib.purdue.edu/cgi/viewcontent.cgi article=3258\&context=clc web

Information about the author: Oksana Prihodko,

$\mathrm{PhD}$, Candidate of Pedagogical Sciences, Assistant Professor at the Department of Basic and Special Subjects, National Aviation University 1, Lyubomyr Huzar Av., Kyiv, 03680, Ukraine ORCID ID: orcid.org/0000-0002-9441-4196 


\section{CARNIVAL FIGURE OF A FOOL-WISECRACKER IN THE MODERN LINGUISTIC CULTURE OF THE UNITED STATES AND GREAT BRITAIN}

\section{Svitlana Tarasova}

\section{INTRODUCTION}

In the contemporary communicative socio-cultural space laughter and humor that take place in various spheres of human life play a significant role. They have already become part of our usual living and routine. The person is in the center of the comic which is not limited temporally or spatially. Modernity is reflected as a laughable reality, i.e., it acquires traits of carnivalization. Nowadays takes the form of a modern, long-lasting "carnival" without boundaries. It correlates with dialogism in the culture, the base of which is game. Carnivalization is a permanent, unlimited manifestation of the comic in the socio-cultural environment of today, extending to theater, circus, television, talk shows, mass media and Internet, workplace, home, family etc.

In carnivalization participants are in a direct dialogue not only with each other, but also share knowledge and experience with the world. The addressee is the carnival personality - a person who entertains. A wide nomination is the fool. But its exteriorisation is widespread: it includes professional and non-professional jokers, i.e., everyone who creates humor. The recipient in the carnival space is the audience as part of the linguocognitive society.

The main figure of carnivalization is a discursive personality of a fool-wisecracker. He leads the carnival process. A fool-wisecracker combines qualities of a fool as a person who makes a fool of his behavior - conscious recklessness, wit, cheerfulness; and a wisecracker as one who can mock, joke and make fun of others. A discursive personality of a foolwisecracker has a special carnival worldview. His main purpose is to cheer the audience and create a comic, humorous effect. Thus, the carnival worldview of a discursive personality of a fool-wisecracker is the basis of dialogical relations and a way of influencing the addressee.

In the English-language carnival linguoculture to denote the concept of "fool" there is a lexeme fool (weirdo) known since 1275. It is borrowed from Old French fol "crazy" (modern French fou). The concept of fool came to the Old French language from Latin and had 
several basic meanings: 1) a crazy, mentally ill person, an idiot; 2) a robber, a clown; 3) a skilled person who could handle black work on blacksmith bellows ${ }^{1}$.

Already in Old French ambivalence of this concept's meaning can be traced. It was determined by social, cultural and psychophysical characteristics of a fool. The word "fool" was included into English with meanings "clown" and "jester" only at the end of the fourteenth century.

Currently, the token fool is polysemantic and has a number of lexical variants. According to its lexical characteristics, it refers to highfrequency language tokens ${ }^{2}$ with diffuse pragmatic potential and a variety of lexical and phraseological functionings. In our work, the notion of fool is considered in the space of the carnivalization of the present day, basing on the semantics distinguished by us: "to pretend," "to entertain," to "make jokes".

For the polysemant fool (n) central is an integral semen "foolery" that lies in the plane of perception of the personality in the world. The works of the English researchers S. Billington "A Social History of the Fool" 3 , E. Wellsford "The Fool: His Social and Literary History" 4 , and X. Davidson "The Hero as a Fool: The Northern Hamlet" "foolery" has been chosen correctly as the integral one. In these works, foolery is presented as a collective name for entertainment and exposure in medieval times ${ }^{67}$. It exists at the intersection of game, joke, wit, mockery and morality, criticism.

1 Vaan M. (2008) Etymological dictionary of Latin and the other Italic languages. Leiden, Boston: Brill.

2 Crystal D. (1987) The Cambridge Encyclopedia of Language. Cambridge: Cambridge University Press

${ }^{3}$ Billington S. A. (1984) Social History of the Fool. London: The Harvester Press

${ }^{4}$ Welsford E. (1935) The Fool: His Social and Literary History. London: Faber and Faber.

${ }^{5}$ Davidson Hilda R. Ellis. (1984) The Hero as a Fool: The Northern Hamlet. The Hero in Tradition and Folklore. London: Folklore Society

6 Otto B. (2008) Duraki: Te, kogo slushayut koroli [Fools: Those Kings Listen]. Saint Petersburg: Azbuka. (in Russian).

7 Reed Cory A. (2015) The Ingenious Simpleton: Upending Imposed Ideologies through Brief Comic Theatre by Delia Méndez Montesinos. Comparative Drama, no. 49, pp. 101-104 
All the values of the polysemant fool $(n)$ are grouped by the radialchain type which determines presence of the complete common semantic component and its extensions in the lexical structure of the concept.

Here are the most common lexical meanings (hereinafter referred to as "LM") of the polysemant fool $(n)$. They are built on the base of semantic interpretations from the most authoritative lexicographic sources of English ${ }^{8910}$ : LM 1 - a stupid person; LM 2 - a person with a mental disorder; an idiot; LM 3 - a folklore fool who is a character of fairy tales; LM 4 - narrow meaning of fool $(n)-$ a form of describing a person who performs acts for the sake of fun and must seem ridiculous to society due to his socio-professional position; LM 5 - narrow meaning of fool $(n)$ - a professional clown who lives in a royal or noble household; LM 6 relational meaning of fool $(n)-$ a person who often entertains others and is derided; LM 7 - relational meaning of fool $(n)$ - a person who criticizes order and surroundings, causing disagreement.

LM 1 and LM 2, which describe foolery as a negative quality, are not considered in this study because they do not correlate with its object, namely a carnival discursive personality of a fool-wisecracker.

LM 3 is a fiction manifestation of a fool's figure in the carnival space. Folk fool is an object of mockery, but over time, mockery benefits him; thanks to his wit and temper, he finds his happiness by being smarter than he seems. But LM 3 is also excluded from nominations of fool $(n)$ a carnival discursive personality of a fool-wisecracke, since modern real speech space is being explored.

Thus, a carnival discursive personality of a fool-wisecracker is represented by LM 4, LM 5, LM 6 and LM 7. These LMs are considered by scientists as various meanings related to a personality of a fool. However, they are a complex system of carnival communication of a carnival discursive personality of a fool-wisecracker with the world. A fool-wisecracker is a basic element of a carnival culture that seeks to entertain and make fun of others.

Based on the analysis of lexical-semantic meanings, a foolwisecracker is a discursive personality with a non-standard carnival worldview. His basic feature is stupidity which takes forms of intellectual

${ }^{8}$ Lexicon Publications (1993) New Webster's Dictionary and Thesaurus of the English Language. New York: Lexicon Publications

${ }^{9}$ Longman Dictionary Online. Retrieved from: http://www.ldoceonline.com/

10 Merriam-Webster Dictionary. Retrieved from: http://www.merriamwebster.com/dictionary/American 
comism, joke and mockery. A fool-wisecracker is a clown by his socioprofessional position; a professional jester at court, a philosopher clown; a joker, a critic. These subspecies are divided by institutional parameter into socio-professional and non-professional spheres.

The socio-professional sphere (class, profession) of the carnival discursive personality of a fool-wisecracker combines: creation of a new image with an entertaining function, socialization of a person in a certain society - a social and professional status, demonstration of modesty, selfimportance, influence and significance; use of brightness and variety in language. According to the analysis of direct vocabulary notions, the types of carnival discursive personalities of a fool-wisecracker corresponding to LM 4, LM 5 and LM 7 are the clown, the jester and the trickster.

In the non-professional sphere the behavior of the carnival discursive personality of a fool-wisecracker demonstrates unpretentiousness, high moral, simplicity, high appreciation of his own merits. It serves as a differential sign of cunning. LM 5 and LM 6 by direct vocabulary notions correspond to the categories - the buffoon and the trickster

\section{Clown and jester}

Peculiarities of the communicative behavior of the clown and the jester in the linguistic culture of the USA and Great Britain are determined by their social and professional spheres. Being a foolwisecracker is their job, a certain professional duty, responsibility.

I. Clown. In modern communicative space, the clown is a circus, variety or theater actor. His main techniques to create humour are grotesque and buffoonery. The carnival personality of the clown is also determined by his physical qualities used during the play - balance, juggling, mimicry.

As a type of a fool-wisecracker, the clown's main task is to make fun of the audience he works with. The ways of its implementation are:

1) Costume and external attributes. Clowns activate linguosituative hyperbolization and grotesque in the carnival space: exaggeration of facial details and highlighting them in red, black (colouring of sad clowns (Auguste) ${ }^{11}$ ), white (colouring of cheerful

11 Schechter J. (2013) Popular theatre: A sourcebook. Great Britain: Routledge. 
clowns (White clown) ${ }^{12}$ ) colors; tendency to choose clothes of a wrong size and tone; combination of too bright colors. Such a mixture of incompatible causes the recipient's reactio - laughter. The most notable clowns due to their colors and underlining exterior features are sad clowns: Albert Fratellini, Lou Jacobs, Greg and Karen DeSanto, Coco the Clown, and Charlie Rivel; fun clowns: Glenn "Frosty" Little, Joseph Grimaldi, George "G. L" (popularizer of Humpty Dumpty history), François Fratellini and Felix Adler.

2) Caricature and grimace. These characteristics of the clown implement techniques of linguistic situational stylization, demonstration of realities, mixing styles that lead to comic. For example, tramp or hobo clown stands out in the USA and UK. They play a role not just as a clown, but by their eccentric behavior they "clown" existence of certain layers of the population. The most popular role models for the English speaking space are the sportsman (Richard Martin "Rick" Hader), the baker (Peter Shub), the police officer (Harold Lloyd), the housewife (Barry Lubin) and the tramp (Avner Eisenberg "Avner the Eccentric") ${ }^{13}$. These roles are chosen by clowns deliberately as they are the most social professions reflecting lives of ordinary Englishmen and Americans. The realities of these professions shown by clowns lead to absurd which results in paradox, contrast and a violation of the logics.

The ways that the clown refers to in displaying himself in a hypertrophied form and demonstrating an absurd image of the world to entertain the public, are summarized in the table (Table 1):

Table 1

Basic techniques of the clown comism

\begin{tabular}{|c|c|c|}
\hline Display & \multicolumn{2}{|c|}{ Language and stylistic devices } \\
\hline suit & hyperbolization & paradox \\
external attributes & grotesque & contrast \\
caricature & realities & violation of the \\
grimace & mixture of styles & logics \\
\hline
\end{tabular}

Modern English-speaking clown space is characterized by variability in the use of the clown figure. These are: a) theatrical

12 Roberts J. (1991) Strutter's complete guide to clown makeup. London: Piccadilly Books.

13 Praill A. (1998) The United Kingdom: A Modern Tradition. London: Darling Print 
scaffolding, comedy-farce theaters where he plays himself: Druri Lane, Sandlers Wales ${ }^{14}$; b) stage shows: Clowning around, Friendly Clown; c) television shows (One day with Jim, Who is the Dumb?); d) stationary circuses (equestrian clowns, mimes, sad and cheerful clowns perform together) - Bozo, Cookie, Buttons, Rebo, Homer, Grock, Grandma, Weary Willie; e) Internet (circus clowns' blogs and vlogs, online clowns) - Tutti the Clown; Vanilla Swirl. The most widespread are clowns-mimes, monologue clowns (the spoken genre), musical clowns, carpet clowns that fill the gaps between theatrical performances.

From the beginning of the twentieth century. in the United States and the United Kingdom specific types of clowns are becoming more widespread:

- the scary or evil clown who is an embodiment of not only laughter but also horror. This clown is compared to a murderer, a demon, a Blue Beard, a thief. He is a negative character; his main weapon is black humor. He is eager not to make fun or improve the mood, but to scare, to hurt, to offend, to do harm. Negativity of this clown is also evident in its appearance: sharp lines on the face, use of poisonous colors, smug smile added to the makeup (Fig. 1). The role of the evil clown cannot be regarded as a kind of a fool-wisecracker because of incompatibility of their strategies and tactics with the latter. He is terrifying and is a complete antithesis of a fool-wisecracker.

-the hospital clown or clown-doctor. This type of clown is the main character in the hospital clown genre which was first identified in the USA as a way of creating laughing. Hospital clowning is a system of measures aimed at rehabilitation of patients undergoing hospital treatment with the help of clowning. Hospitals and wellness facilities are places of action for the hospital clown. Performers in the hospital clown genre can be both professional actors as well as amateurs who have undergone a special training to work with patients using humor, even doctors dressed in clown costumes (Fig. 2).

The main function realized by the hospital clown is psychotherapeutic function. The hospital clown communicates with the patient only in the key directed to positive emotions. He forms the setting of recovery for the future. Hospital clowning is directly applicable to patients who are already recovering and have a positive tendency in

14 Jewell P. (2005) Humour in Cognitive and Social Development: Creative Artists and Class Clowns. International Education Journal, vol. 2, no.6, p.200 
treatment. The clown's actions are aimed at regularly assisting patients in coping with ongoing stress in the hospital at all stages of treatment ${ }^{15}$. In the non-verbal sphere comic play and pantomime are involved. In verbal, humor is expressed through language, stylistic and logic-speaking means (homonymy, repetition, shibboleth, polysemy, pun, allogism, etc.). To make patients interested and create an atmosphere of calm, the hospital clown uses humorous poems, humorous songs, jokes, anecdotes, limericks.

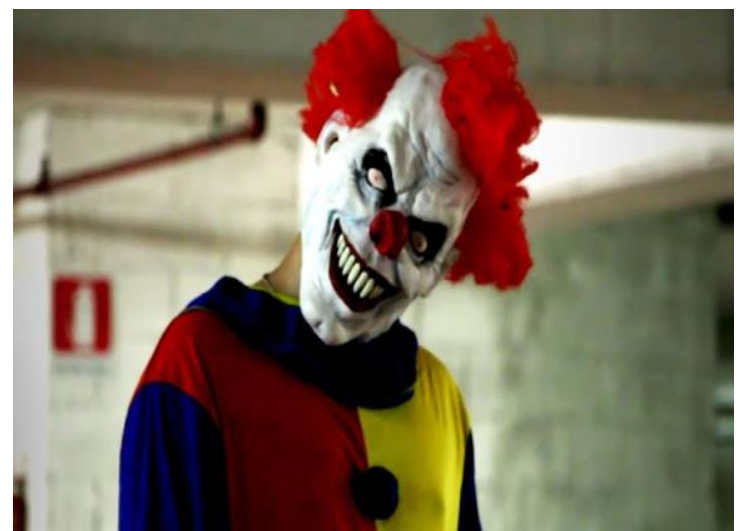

Fig. 1. Scary or evil clown

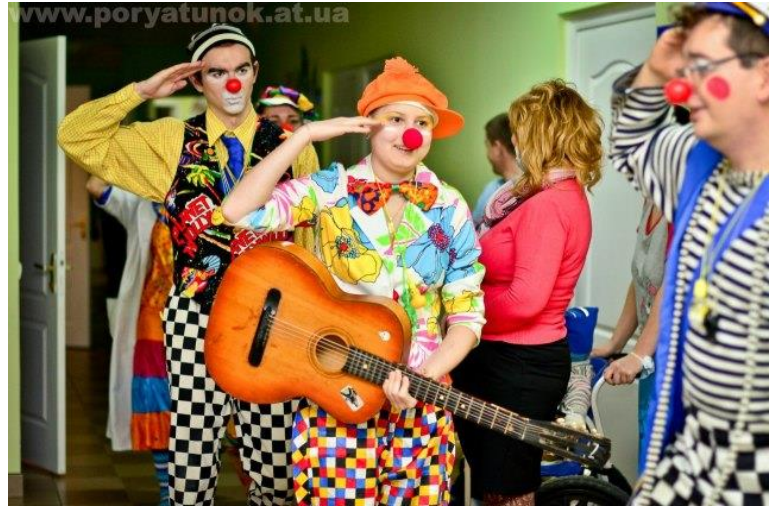

Fig. 2. Hospital clown or clown-doctor

15 Davidson Hilda R. Ellis. (1984) The Hero as a Fool: The Northern Hamlet. The Hero in Tradition and Folklore. London: Folklore Society 
II. Jester is an actor with weird behavior, but in his jokes this comic discursive personality hides his true thoughts and experiences. Nowadays the jester performs as a stand-up comedian, humorist, monologue actor, satirist, parodist, etc. In his speeches he reflects funny moments of modern life, disadvantages of society. The jester ridicules others, especially those of a higher social status.

The main strategy used by the jester as the bearer of the comic element is to entertain the audience. His "stupidity" and disobedience are conscious. His misunderstanding and irrationality are artificial. The main tactic of the jester to implement his role as a fool-wisecracker in the carnival space is intellectual comism: he is a professional artist who is a part of everyday life - he combines roles of "entertainer" and "philosopher". The jester presents the truth in a metaphorical, symbolic, veiled form. This truth is obvious to the public, but the latter prefer not to notice it because it is not to their benefit, it shows them in a bad focus.

The United States of America and the United Kingdom are two leading countries that have presented the largest number of jesters to the world $^{16}$. There is a variety of their manifestations:

a) entertainment venues (cabarets, clubs, improvisation theaters) Borscht Belt; Chitlin Circuit. The jester performs live in front of the public. His speeches are mostly satirical and sarcastic jokes, reprises and black humor;

b) comic theatre and television shows (The Wheeltappers, Shunters Social Club). The most striking manifestation is the stand-up comedy genre $^{17}$, which now obtains the highest ratings on the USA and UK television. Comedian critic Brian $\operatorname{Logan}^{18}$ states that since 2003, particularly during 2013-2016, there has been an "explosion" of stand-up comedy in the English-speaking countries. The proof of this is the increase in number of stand-up television programs: Stewart Lee's Comedy Vehicle [BBC2 2009-], Live at the Apollo (BBC 1 2004-), Michael McIntyre's Comedy Roadshow [BBC1 2009-] and Comedy Rocks with Jason Manford [ITV 2010-1; the growing number of

16 Nilsen A. P., Nilsen D. L. F. (2000) Encyclopedia of 20 th-century American Humor. Phoenix: Oryx Press

${ }^{17}$ Kotthoff H. (2007) Oral genres of humor. Pragmatics. Quarterly Publication of the International Pragmatics Association (IPrA), vol.2, no.17, pp. 263-296.

${ }^{18}$ Hyde L. (2017) Trickster Makes This World: How Disruptive Imagination Creates Culture. Edinburgh: Canongate Books 
comedians who act as commentators on serious television talk shows as Question Time [BBC1, 1979-];

c) festivals and conventions (Leicester Comedy Festival, Edinburgh Fringe Festival);

d) Internet (blogs, vlogs, online meetings, streaming channels, skype meetings, social networks, etc.). The jester via the Internet comments on the most current issues in a live mode. For example, clowns Alan Carr, Lee Evans, Peter Kay, Jason Manford have their own Youtube channels and social media pages (such as Twitter, Facebook). They speak to their online followers, publish their humorous videos, organize online festivals or even comedian fights.

One of peculiarities of jesters from the United States of America and Great Britain is their appearance on stage with the help of a preconceived opening statement ${ }^{19}$. It helps the public to navigate how to greet the jester or how the performance will be developing (whether it is possible to interrupt the jester or not).

Engaging the audience in the jester's game is vital for successful organization of performances. F. Scarpetta and A. Spagnolli define this practice as an "interactive context" 20 . This can be questions to the audience in order to encourage and evaluate the temperament and mood of the public; jargon; exclamations; analysis (engaging the audience in the preface with a joking comment and testing their response); references to the audience in performances (pags).

The list of modern clowns in the USA and the UK has more than 2065 people (according to the Internet). The brightest jesters who have been able to show themselves up in several professional spaces are Conan O'Brien, Dane Cook, Dave Chappelle, David Letterman, Frank Caliendo, George Carlin, Jay Leno, Jon Stewart, Lewis Black, Rodney Dangerfield, Sarah Silverman, Stephen Colbert, Steven Wright ${ }^{21}$.

In addition to the mentioned jesters, the main feature of the carnival space of the USA and the UK is a growing number of classic jesters. They are corporate and official ones. These types of jesters combine entertainment and satirical functions.

${ }^{19}$ Rutter J. (2000) The Stand-up Introduction Sequence: Comparing Comedy Comperes. Journal of Pragmatics, no.32, pp. 463-483

${ }^{20}$ Scarpetta F., Spagnolli A. (2009) The Interactional Context of Humor in Stand-up Comedy. Research on Language and Social Interaction, no. 42, pp. 210-230.

21 Nilsen A. P., Nilsen D. L. F. (2000) Encyclopedia of 20 th-century American Humor. Phoenix: Oryx Press 
1) Corporate jester. The sphere of his manifestation is offices, business organizations in which officially there is a jester job. For example, an ad appeared on The Times on August 5, 2014: "Jester wanted. Must be mirthful and prepared to work summer weekends. Must have own outfit (with bells). Bladder on stick provided if required"22.

There are many examples of taking a corporate jester to work. E.g. Pablo Birch was the corporate airman (jester) of the British Airlines in 1994. Birch's responsibilities were developing creativity of the managers and convincing them in comic form that although they were principal, they were not always right. He could say out loud what other employees feared. In England, for example, today there are over 400 corporate jesters working full-time or part-time. The National Guild of Corporate Jesters was created and is led by Jonathan the Jester.

On the one hand, the corporate jester is a serious office worker by his appearance and demeanor, but, on the other hand, in his outward seriousness he disguises ridicule, subjugation, condemnation and joking others. His highly intelligent sense of humor seeks to self-criticize and sneer at himself and others. In addition to the comic means most often used by comedians, the corporate jester resorts to immorality in humor. He uses obscene vocabulary in his jokes ${ }^{23}$. Corporate jester sees it not as an invective or something offending, but as a mechanism for contact establishment and expression of true thoughts. S. Eggins and D. Slade state that obscene vocabulary is a way of establishing intimacy, involvement and affiliation ${ }^{24}$. Corporate jesters are prone to sharp satire and irony.

2) Official jester. For the communicative space of the United States of America and Great Britain official jester is a requiem of traditions - a great respect of the English and Americans to tradition. His place of work is government organizations, mayor offices, municipalities. Official jester is a tribute to history.

The most distinctive feature of the official jester is preservation of the traditional jester dress in the image (bells, a cap, a weird hat, a stick, tambourines) combined with linguistic acumen. For example, modern

${ }^{22}$ Scruton R. (2015) Fools, frauds and firebrands: Thinkers of the new left. London: Bloomsbury Publishing

${ }^{23}$ Lee J. Y. (2013) Enter Laughing: American Humor Studies in the Spirit of Our Times. Studies in American Humor, no. 28, pp. 1-15

${ }^{24}$ Eggins S. (1997) Analyzing Casual Conversation. London, Washington: Cassel 
official jesters are Baldwin the Fool and Godfrey Pugh, England's professional jesters; Peterkin the Fool, Bristol's Official Clown; Jonathan the Jester, Salisbury's official jester; Barry Levy the Jester, 2nd Official Clown of Hunford, Berkshire, Swindon and Salzgitter, Hanover; Jane the Phoole, Official jester of the City of Milwaukee, Wisconsin, USA; Fool Monty, a professional jester at Warwick Castle, United Kingdom; Kris Katchit, Derbyshire jester; Alex G, Montreal's professional jester; Nigel Roder, Aka Kester the Jester, England's official national jesters since 2004; Pocket the Fool, a professional jester at the Kentucky Festival.

Official jesters present themselves as intelligent jokers with a keen mind. Their humour is classic but mostly theatrical - they play jesters of past eras in the present. In language it is reflected by inclusions of precedent texts, updated aphorisms and quotations.

The defined features of the jester as a kind of the carnival discursive personality of a fool-wisecracker of the USA and UK reproduce a ridiculous perception of reality by the English-speaking culture. These means are focused on presentation of actual problems to the public in the context of carnival speech.

\section{Buffon and trickster}

In the linguistic culture of the United States and Great Britain buffoons always act as non-professionals while tricksters act in both fields - the non-professional and professional ones (they are not professional comedians, but the use of humor is a requirement of their employment agreement). Each person can acquire characteristics of a buffoon or trickster by his communicative behavior: giving reality features of frivolity, ambiguity, humor, interpretation of everyday life in an unusual perspective according to the code of comic tonality.

I. Buffoon. The basic strategy of this kind of a fool-wisecracker is to play, joke, be funny to others, and bring joy to others. To implement it the main tactic chosen by the buffoon is to change the atmosphere, setting; he makes the audience to play with him and follow his game. This is reflected in appropriate tactics:

\section{- Prepared improvisation}

The buffoon's humor is not evil; its purpose is joking, not ridicule. A characteristic feature of the buffoon's humor is his improvisation ${ }^{25}$. But

${ }^{25}$ Apostolides M. (2016) From an Authorial Persona to a Postpedantic Philosopher, So That We Might Both Become Idiots. Comparative and Continental Philosophy, vol. 8, no. 2, pp. 216-223 
this improvisation is a pretended one - the buffoon's jokes do not come from a blank sheet. The buffoon is a well-known trick-player; his improvisations are prepared in advance; jokes corresponds the situation. Still he presents them to the audience as improvisation, every time in a new way.

\section{- Selection of the setting independently}

Among all his jokes thought up beforehand the buffoon chooses those that can be substituted or adjusted to the situation, i.e., he determines the time and place when this or that joke will be relevant and will be adequately perceived. The buffoon also thinks about the development of ongoing events. To make coherent jokes he needs information in advance: topics of future conversations, participants of communication, their goals, knowledge, and motives.

\section{- Interaction of the buffoon and audience}

This game is mutual. In this interaction the buffoon fakes (premade improvisations) while the audience plays to it: the buffoon's jokes are a surprise to the audience, although this is obviously not the case. The modern buffoon is trying on the role of a person from whom something ridiculous is expected - actions, statements, scenes ${ }^{26}$. The modern buffoon is a hostage of his image.

Integral characteristics of the buffoon of the United States and Great Britain are erudition, socialization, humorousness, emotionality. But the mentality of the English and Americans imprint on the communicative preferences of the buffoon.

The British buffoon jokes about himself, his national traits and mentality. He brings the following genres to his speech: fictional noodle stories or bawdy stories. They are filled with comism and a focus on entertainment, humor and creation of a joking mood, i.e., the thing needed by the ordinary person at the time of leisure after hard, exhausting work ${ }^{27}$. These humorous stories are dominated by intellectual forms of humor, such as absurdity, pun, paradox ${ }^{28}$. Characteristic communicative features

26 Balcerzak S. (2013) Buffoon Men: Classic Hollywood Comedians and Queered Masculinity. Detroit: Wayne State University Press

27 Reed T. (2013) Book of Fools An Intelligent Person's Guide to Fops, Jackasses, Morons, Dolts, Dunces, Halfwits and Blockheads. New York: Algora Publishing

${ }^{28}$ Hamburg L. O. (2003) Ser Dzhon Fal'staf, mister Pikvik, Dzhivs i vse-vsevse... Angliyskiy yumor, ego literaturnye $i$ real'nye geroi. [Sir John Falstaff, 
of the British buffoons are jokes, irritation, mockery, deception, paradox, hyperbolization, absurdity. The humorous tone causes an emotional response of the audience - laughter, smile, applause, and joke in response.

The American buffoon is a prototype of ironic and sarcastic perception of everyday life. The verbal component of his humorous speech is jokes on all occasions (religion, medicine, politics, economics, family values, public problems and shortcomings) and fables as a form of easy-percept humor. The humor of the American buffoon is light, sometimes somewhat transparent. He addresses absurdity, incongruity, exaggeration, parody, paradoxes in it.

The behavior of the English and American buffoons is determined by life situations and performs a number of functions: 1) to help himself and others to cope with life's difficulties; 2) to ridicule life and its absurdity; 3) to achieve communicative success (buffoons are souls of every society).

II. Trickster. The main strategy of the English-language trickster is to entertain others and harmonize relationships with the audience as a result of involving the comic. But the comic reinterpretation of reality with this kind of a fool-wisecracker is irony, sarcasm, and mockery. Characteristic features of the modern trickster are:

\section{- Folk reinterpretation of reality}

This technique is used by the modern trickster in production of humor. Humor is used by trickster as a subjective interpretation and usually hyperbolized projection of life and historical conditions that underlie them.

Topics for jokes are characterized by their diversity regarding eternal human problems ${ }^{29}$. The English-speaking trickster chooses real figures as referents of his considering them as folklore characters. The most prominent are John Barleycorn, Lady Godiva of Coventry, Hereward, Herne the Hunter, Punch. For example, during Halloween, people wear animal costumes or add zoomorphic attributes to their images: deer antlers, bat wings, cat mustaches, etc.

Mr. Pickwick, Jeeves and all-all-all ... English humor, its literary and real heroes]. Kiev: Gramota. (in Russian)

${ }^{29}$ Dormann C. (2014) Fools, tricksters and jokers: categorization of humor in gameplay. International Conference on Intelligent Technologies for Interactive Entertainment. Springer: Cham, pp. 81-90 
Zoomorphism in humor is used by tricksters not only during holidays, but also in politics. The following figures show a trickster presentation of the US and UK politicians (Fig. 3):
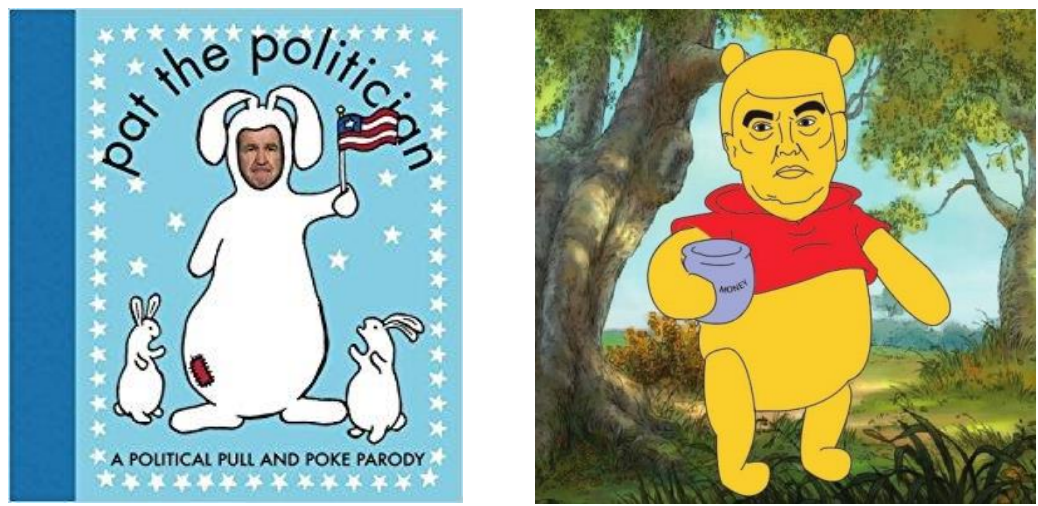

Fig. 3. A trickster presentation of the English-speaking politicians:

1 - J. Bush in the image of a hare; 2 - D. Trump as a bear

A stylized video of relationship between D. Trump and H. Clinton in the images of The Muppet Show Mashup for the Mahna Mahna song has become popular online (Fig. 4):

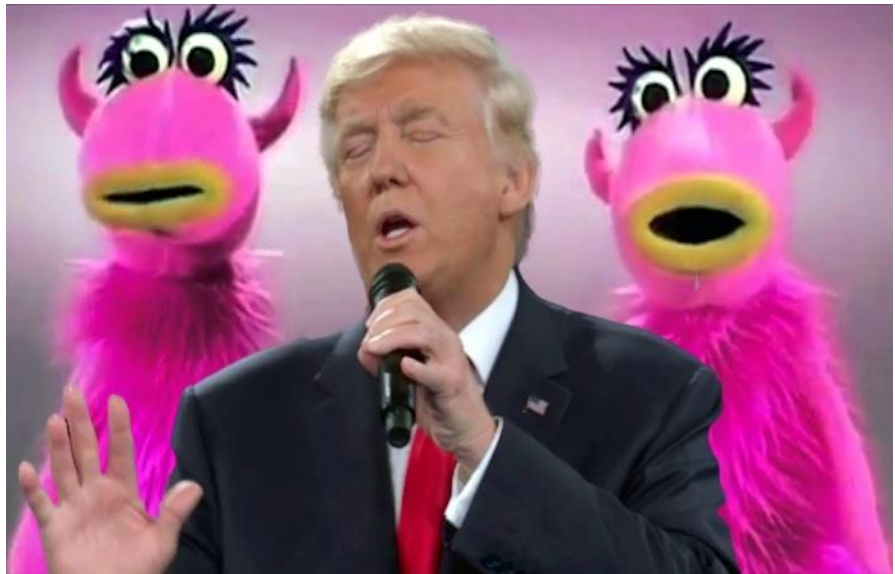

Fig. 4. D. Trump in the image of The Muppet Show Mashup on song Mahna Mahna 


\section{- Trickster imagery and women's behavior}

Traditional English-speaking tricksters have always been male, and even while having transformations, the latter image was always male. Modern carnival personalities of female tricksters are eager to break gender stereotypes - trying on male images. Men's gender peculiarities of women tricksters are observed in their appearance (short cut hair, choice of pants, not skirts, smoking a cigarette), as well as in speech - the use of obscene vocabulary and black humor more than men. This is provoked by their masculine image and democratization of society - women are allowed more. Embodying the role of the trickster, they show themselves as more characteristic and volitional personalities than they really are (Fig. 5).
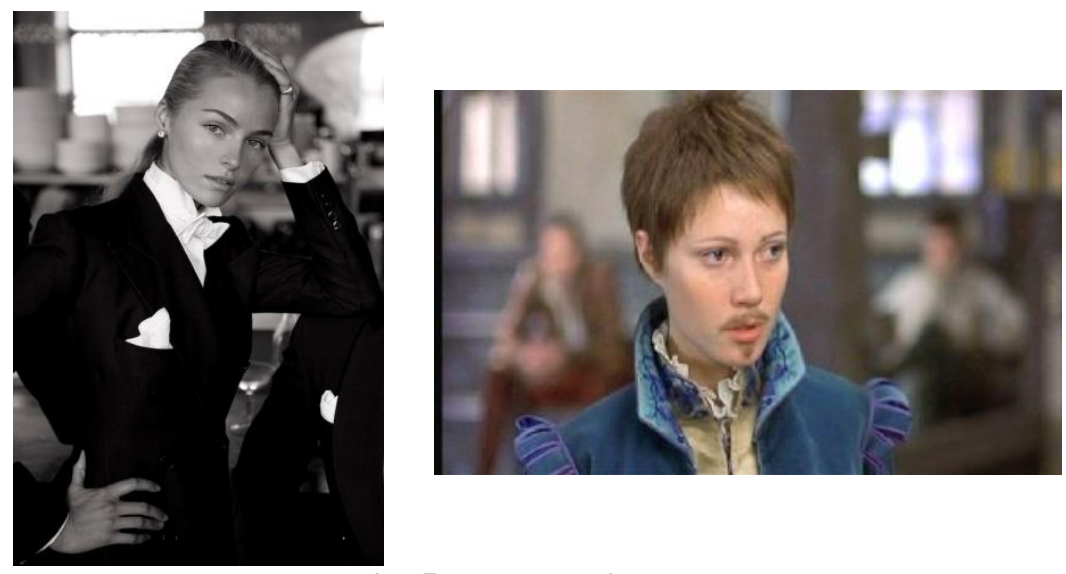

Fig. 5. Female tricksters

When trying on masculine images modern female tricesters acquire figures of folklore triksters. Their main feature is cunning. For the woman trickster all techniques are appropriate and acceptable to achieve the goal - attention from others. The woman trickster only pretends to be a trickster. Trick is her main technique. These characteristics are acquired by politician $\mathrm{H}$. Clinton, political scientist and journalist S. Power, Presidential Advisor S. Rice, artist M. Brown. For example, H. Clinton has an inappropriate style of clothing (trouser suits), smokes cigarettes in public, uses jargon during debates, has unusual laughter that is surprising, because she is a typical trickster woman. She positions herself as a trickster, though she is not. All this is just an image, a mockery, a mockery to win the attention of the audience. Her appearance is only a 
delusion, which is used as a tool to achieve the goal and assertiveness against the background of the audience.

\section{- Trickster positioning in historical space}

The modern US-UK trickster in his speech also manages to capture the characteristics of past eras. He forms the image of a trickster-intrigue. An organic example of acquiring trickster traits in a historical diachronic plane is L. Carroll who wrote Alice in Wonderland. This piece of art is filled with trickster characters - Rabbit, Cheshire Cat. They call themselves abnormal because they know that they are living in an abnormal world (the Rabbit is constantly in time, worrying that time ends but it cannot be true; he does not even understand absurdity of the situation, having a clock). Therefore, these characters are forced to be so, although they are very logical.

The Rabbit and the Cheshire Cat are cross-country guides to Alice's journey as well as a reader's. They bring balance to Wonderland, full of chaos and confusion. All their actions are thought out in advance, they know what they are doing; they give Alice the answers, but not the ones she wants to hear, they prompt her to take the right steps. Rabbit and Cheshire Cat are tricksters, scoffers; L. Carroll was able to present their images in a work of art, so he is also a trickster.

The US and UK trickster is an extraordinary carnival-ridiculous carnival personality who exposes and questions existing truths and stereotypes, innovatively approaches them in a humorous form and choice of stylistic means as well as encourages others to do the same.

\section{CONCLUSIONS}

1. A fool-wisecracker is considered to be a discursive personality who is a leader of the carnival process; the one who puts on a comedian's mask. His purpose is to communicate with the public in the form of a comic play. In order to do it he uses witty verbal, non-verbal and supraverbal means.

2. A fool-wisecracker shows up himself in social, professional and non-professional fields. According to the analysis of direct vocabularies of lexical-semantic meanings corresponding to the figure of a foolwisecracker the clown, the jester, and the trickster belong to the socioprofessional sphere; to the non-professional sphere - the buffoon and the trickster.

3. In the modern communicative carnival space of the United States of America and Great Britain peculiarities of manifestation of a foolwisecracker's types are: 
- particular spread of a hospital clown (hospital clowning genre) as a tool of laughter therapy. Hospital clowning is a system of measures aimed at rehabilitation of patients undergoing treatment in hospital with the help of clowning techniques. An exceptional feature of a hospital clown is that he can be either a professional actor or an amateur after the courses undergone, or even a doctor in a clown costume;

- increasing number of authentic jesters at working places corporate and official jesters. Peculiarity of the corporate jester's humor is use of obscene and minor vocabulary as mechanisms of contact establishment; official jesters - copying of the ones in the present.

- usage of speech inclusions by the English-language buffoon to create a comism. A noodle story or a bawdy story states for the British buffoon; anecdotes and stories - the American buffoon. His improvisations are prepared and supported by the audience.

- transferring of the trickster's zoomorphic traits to the modern communicative space in forms of reference and stylization of folklore characters, acquisition of masculine features by women (female tricksters).

4. The topic provides prospects for further study of discursive personalities of the clown, the jester, the buffoon and the trickster of the USA and Great Britain in comparison with their representatives in other cultures, in particular the English-speaking world. It also underlines problems of multimodality of a fool-wisecracker's types in their representations in English-language artistic discourse and in virtual space.

\section{SUMMARY}

The paper deals with a discursive personality of a fool-wisecracker. $\mathrm{He}$ is proven to be the basis of carnival culture. A discursive personality of a fool-wisecracker intentionally puts on the comic's mask and draws the addressee to the comic play with his jokes, using clever verbal and non-verbal means. His main characteristics are focus on entertainment, pretending to be a fool, a critical perception of the world, language wit, expression of philosophical views and thoughts in a comic form. A discursive personality of a fool-wisecracker is characterized by a high speech culture which is expressed in the combination of verbal, nonverbal and supra-verbal means to create comic. In the English language space there are four basic types of a fool-wisecracker: the clown, the jester, the buffoon and the trickster. They are determined within professional and non-professional spheres of human life. 


\section{REFERENCES}

1. Apostolides M. (2016) From an Authorial Persona to a Postpedantic Philosopher, So That We Might Both Become Idiots. Comparative and Continental Philosophy, vol. 8, no. 2, pp. 216-223.

2. Balcerzak S. (2013) Buffoon Men: Classic Hollywood Comedians and Queered Masculinity. Detroit: Wayne State University Press.

3. Billington S. A. (1984) Social History of the Fool. London: The Harvester Press

4. Crystal D (1987) The Cambridge Encyclopedia of Language. Cambridge: Cambridge University Press.

5. Davidson Hilda R. Ellis. (1984) The Hero as a Fool: The Northern Hamlet. The Hero in Tradition and Folklore. London: Folklore Society.

6. Davison J. (2016) Documenting clown training. Comedy Studies, vol.7, no. 1, pp. 13-20.

7. Donetz P. M. (2001) Osnovy obshchey teorii mezhkul'turnoy kommunikatsii: nauchnyy status, ponyatiynyy apparat, yazykovoy $i$ neyazykovoy, voprosy etiki i didaktiki [Fundamentals of the general theory of intercultural communication: scientific status, conceptual framework, linguistic and non-linguistic one, ethics and didactics]. Kharkiv: Shtrich. (in Ukrainian)

8. Dormann C. (2014) Fools, tricksters and jokers: categorization of humor in gameplay. International Conference on Intelligent Technologies for Interactive Entertainment. Springer: Cham, pp. 81-90.

9. Eggins S. (1997) Analyzing Casual Conversation. London, Washington: Cassel.

10. Hamburg L. O. (2003) Ser Dzhon Fal'staf, mister Pikvik, Dzhivs i vse-vse-vse... Angliyskiy yumor, ego literaturnye i real'nye geroi. [Sir John Falstaff, Mr. Pickwick, Jeeves and all-all-all ... English humor, its literary and real heroes]. Kiev: Gramota. (in Russian)

11. Hyde L. (2017) Trickster Makes This World: How Disruptive Imagination Creates Culture. Edinburgh: Canongate Books.

12. Jewell P. (2005) Humour in Cognitive and Social Development: Creative Artists and Class Clowns. International Education Journal, vol. 2, no.6, p.200.

13. Kotthoff H. (2007) Oral genres of humor. Pragmatics. Quarterly Publication of the International Pragmatics Association (IPrA), vol. 2, no. 17, pp. 263-296. 
14. Lee J. Y. (2013) Enter Laughing: American Humor Studies in the Spirit of Our Times. Studies in American Humor, no. 28, pp. 1-15.

15. Lexicon Publications (1993) New Webster's Dictionary and Thesaurus of the English Language. New York: Lexicon Publications

16. Longman Dictionary Online. Retrieved from: http:// www.ldoceonline.com/

17. Merriam-Webster Dictionary. Retrieved from: http:// www.merriam-webster.com/dictionary/American

18. Nilsen A. P., Nilsen D. L. F. (2000) Encyclopedia of 20 th-century American Humor. Phoenix: Oryx Press.

19. Otto B. (2008) Duraki: Te, kogo slushayut koroli [Fools: Those Kings Listen]. Saint Petersburg: Azbuka. (in Russian).

20. Praill A. (1998) The United Kingdom: A Modern Tradition. London: Darling Print.

21. Reed Cory A. (2015) The Ingenious Simpleton: Upending Imposed Ideologies through Brief Comic Theatre by Delia Méndez Montesinos. Comparative Drama, no. 49, pp. 101-104.

22. Reed T. (2013) Book of Fools An Intelligent Person's Guide to Fops, Jackasses, Morons, Dolts, Dunces, Halfwits and Blockheads. New York: Algora Publishing.

23. Roberts J. (1991) Strutter's complete guide to clown makeup. London: Piccadilly Books.

24. Rutter J. (2000) The Stand-up Introduction Sequence: Comparing Comedy Comperes. Journal of Pragmatics, no. 32, pp. 463-483.

25. Scarpetta F., Spagnolli A. (2009) The Interactional Context of Humor in Stand-up Comedy. Research on Language and Social Interaction, no. 42, pp. 210-230.

26. Schechter J. (2013) Popular theatre: A sourcebook. Great Britain: Routledge.

27. Scruton R. (2015) Fools, frauds and firebrands: Thinkers of the new left. London: Bloomsbury Publishing.

28. Starobinskiy G. (2002) Portret khudozhnyka v obrazi blaznja [Portrait of an artist in the image of a clown]. Moscow: Uni Press. (in Ukrainian)

29. Tobias A. (2007) The postmodern theatre clown. Clowns, fools and picaros: Popular forms in theatre, fiction and film, no. 43, p. 37.

30. Vaan M. (2008) Etymological dictionary of Latin and the other Italic languages. Leiden, Boston: Brill. 
31. Van Dijk T. A. (1989). Yazyk, poznanie, kommunikatsiya. [Language, cognition, communication]. Moscow: Progress.(in Russian)

32. Welsford E. (1935) The Fool: His Social and Literary History. London: Faber and Faber.

Information about the author: Svitlana Tarasova, $\mathrm{PhD}$ (Doctor of Philosophy), Associate Professor, Lecturer, V. N. Karazin Kharkiv National University 4, Svobody Square, Kharkiv, 61022, Ukraine ORCID: https://orcid.org/0000-0002-6585-6163 
DOI https://doi.org/10.36059/978-966-397-194-0/196-211

\section{THE METHODS OF WORKING WITH THEMATIC TEXTS IN ESP CLASSES}

\section{Svitlana Chernyshova}

\section{INTRODUCTION}

The globalization and digitization of society in the $21^{\text {st }}$ century require a radical revision of all areas of human activity, mainly the educational system and teaching. Ukrainian expert in English language studies, Professor of Uzhhorod University Myroslava Fabian in her recent research provides an important thesis that reveals the stress points of the contemporary communication and learning studies talking into account the importance of communicative paradigm in which we exist:

Nowadays the world is based on communication which presupposes the process of sharing meaning through verbal and nonverbal behaviour. In our time of globalization, we have more to be exposed to and share with than ever before in terms of culture - beliefs, worldviews, values, attitudes and ideologies - but at the same time much of them remains different and unshared, which is enhanced by raising people's awareness of cultural, ethnic, and religious identities. The Internet and modem technology have opened up new marketplaces, and allow us to promote our businesses to new geographic locations and cultures. Today, we communicate beyond the national borders by emailing, chatting, blogging, web browsing besides speaking and writing. In these days of global networking, we are thrown into the society of hybrid, changing and conflicting cultures, where we are expected to become pluricultural individuals. In the light of cross-cultural communication, the language policy and planning of the Council of Europe is a grand experiment based on plurilingualism and pluriculturalism.

Effective communication with people of different cultures is especially challenging. Cultures provide people with ways of thinking ways of seeing, hearing, and interpreting the world. Moreover, the same words can mean different things to people from different cultures, even when they talk the "same" language. When the languages are different, 
and translation has to be used to communicate, the potential for misunderstandings increases ${ }^{1}$.

The world has changed - students have changed and teachers have to change as well. Most modern students from around the world are the representatives of generation $Z$ by their age, according to 'The Theory of Generations' developed by American researchers William Strauss and Neil Howe. Generation Z refers to the children born after 1995 in digital reality. The ability to "see" multiple screens simultaneously generates the ability to perceive information quickly and to process it instantaneously. Therefore, traditional forms and methods of teaching aimed at gaining knowledge by presenting information by the teacher and passive memorizing it by the student are not effective today.

The Ukrainian scholar Iryna Andrusiak argues that

In foreign language teaching, a search for the most effective way is one of the tasks applied linguists has been trying to fulfill over a century. There has been a lot of debate and discussion about the centrality of grammar and vocabulary in the language curriculum, the importance of accuracy and fluency in the learners' language development, effective methods, approaches and learning strategies of EFL teaching. Although much has been done to solve the most debatable problems, the teaching profession is continually exploring new ways of addressing teaching and learning options to establish more effective teaching and learning practices. Alongside the total physical response, the silent way, suggestopedia, community language learning, multiple intelligences, etc., the lexical approach is referred to a set of alternative approaches and methods in language teaching which are hardly ever addressed by national EFL curricula. Therefore, the research focusing on the methodological foundations underlying the lexical approach and its pedagogical implications for EFL teaching proves to be highly topical. It is commonly accepted that vocabulary as well as grammar are central to language acquisition. However, in contrast to grammar, vocabulary teaching in EFL school classrooms does not prove to be effective. The degree to which vocabulary should be taught, corrected and worked on and methods which should be employed are widely disputed in teaching industry. Recently, vocabulary teaching focus has been shifted to teaching more or less fixed strings of words in contrast to word lists. The latter has been the most

${ }^{1}$ Fabian M. (2019). Interdisciplinary approach to cross-language and crosscultural communication studies. http://respacoll.uzhnu.edu.ua/article/view/187079/ 186480 (accessed 12 January 2020), p. 10. 
popular strategy that both teachers and learners employ throughout a great many years ${ }^{2}$.

It should be noted that on December 4, 2019, the Ukrainian-British Forum "Excellence in Teaching and Learning in Higher Education" was held in Ukraine, which became the first event in a series of activities in a three-year program aimed at improving the quality of teaching in higher education in Ukraine. The key issues of the forum were teaching excellence as a priority for the development of the European Higher Education Area; professional development of university teachers in Ukraine: status and needs; presentation of the UK experience on improving teaching at universities; presentation of the experience of Ukrainian universities on the professional development of teachers, etc. ${ }^{3}$

Professor Myroslava Fabian underlines the idea the these days

Learning as well as teaching a foreign language implies some degree of becoming aware of a foreign culture, and it is important to understand what we mean by the process of cultural learning. Many students in foreign language classrooms learn the language with little or no sense of the depth of cultural norms and patterns of the people who speak the language. Culture learning is a process of creating shared meaning between cultural representatives. It is experiential, a process that continues over years of language learning, and penetrates deeply into one's patterns of thinking, feeling, and acting. Moreover, the second language learning involves the acquisition of a second identity. This creation of a new identity is at the heart of culture learning, or what some might call acculturation. By culture a shared background (for instance, national, ethnic, religious) resulting from a common language and communication style, customs, beliefs, attitudes and values is meant ${ }^{4}$.

Since any English for Specific Purposes (ESP) course is based on the major-specific discipline, a thematic text is a high-quality and reliable cognitive material that complements the knowledge acquired in the course of the study and ensures that the prospective specialist has a decent

${ }^{2}$ Andrusiak I. (2019). The lexical approach to EFL teaching: methodological foundations and pedagogical implications http://respacoll.uzhnu.edu.ua/article/view/ 188462/187839 (accessed 12 January 2020), pp. 282-283.

http://www.britishcouncil.org.ua/programmes/education/higher-educationemployability/teaching-excellence-forum

${ }^{4}$ Fabian M. (2019). Interdisciplinary approach to cross-language and crosscultural communication studies. http://respacoll.uzhnu.edu.ua/article/view/187079/ 186480 (accessed 12 January 2020), p. 11. 
command of the English language. The selection of educational material follows the provisions of the Common European Framework of Reference for Languages, which states that the basic principles of the selection of language-teaching tools provide for the selection of original texts, taking into account the professional needs of those studying a foreign language [1: 81]. Hence, a thematic text is the main means of learning ESP; a source of thematic vocabulary; and a way of shaping the linguistic, professional and sociocultural competence of students by virtue of 'overlaying' foreign language skills on the substantive content of the profession while performing professional $\operatorname{tasks}^{6}$ [5: 199]. The lexical, grammatical and semantic fabric of the text forms an understanding and sense of the language, developing linguistic and cognitive skills.

Iryna Andrusiak draw's scholars' attention to S. Lindstromberg's theory. The researcher

presents a commonly held view of language competence with regard to both output and input in the following way:

- In speaking and writing:

intended meanings $\Rightarrow$ words + grammar / morphology $\Rightarrow$ meaningful output

- In listening and reading:

input $=>$ grammar + words $=>$ understood meanings $<\ldots>$.

Before the advent of the lexical approach, the popular belief was that a moderately substantial knowledge of grammar and a few thousand words are needed for effective communication. The belief was based on the view on our language ability according to which people have an outstanding ability to combine single words into bigger strings of words in no time to produce meaningful output and to analyse the input by parsing and understanding strings of words. Applying computer metaphor makes the description of our language ability even clearer: human memories are relatively small in a sense that they retain only a few thousand words and grammar rules to apply to them; but human on-line processors are very powerful since they perform combining and parsing operations with single words at lightning speed. Accordingly, in order to

5 Zahalnoieevropeiski rekomendatsii z movnoi osvity: vyvchennia, vykladannia, otsiniuvannia (2003). Nauk. red. ukrainskoho vydannia S. Yu. Nikolaieva. - K. : Lenvit, 2003, p. 81.

6 Sekret I. V. (2010). Model formuvannia inshomovnoi profesiinoi kompetentnosti $\mathrm{v}$ umovakh dystanciynoi osvity. Visnyk LNU imeni Tarasa Shevchenka. № 17 (204). P. 199. 
empower learners' online-processors a wealth of time was spent on grammar" ${ }^{\prime 7}$.

Reading texts in English is one of the ways of learning the English language. Well-selected English texts significantly contribute not only to the enhancement of the linguistic competence but also to the motivation for the student to work independently. Reading texts can differ in terms of both their purposes and the ways in which such purposes are attained. The most common ones include replenishing general or thematic vocabulary; improving the pronunciation of English words and phrases; and revising the rules of English grammar through the analysis of typical examples available in the text. Attaining those purposes obviously requires selecting relevant English texts.

It should be noted that today we need to analyze new methodological approach of teaching English as a foreign language.

As M. Fabian states,

A methodology for investigating how an individual uses language and other semiotic activity to create and use new models of conduct and how this varies from the cultural norm should be incorporated into the study of language socialization. The study of languages other than one's own can serve not only to help one realize what we as humans have in common, but also to assist in the understanding of the diversity which underlines our languages' methods of constructing and organizing knowledge. Such understanding has profound implications with respect to developing a critical awareness of social relationships. Understanding of the latter and the way other cultures work is the groundwork of successful globalization processes functioning ${ }^{8}$.

In terms of their thematic orientation, texts can be characterised by a large variety of grammatical forms and lexical material. The teacher can determine more accurately the students' knowledge of the foreign language and, accordingly, pick up the texts suitable for their level. Texts in English can be taken from specialised journals and newspapers or works written by experts in the field in question. Since student experience certain difficulties in processing a thematic text-due to their lack of

${ }^{7}$ Andrusiak I. (2019). The lexical approach to EFL teaching: methodological foundations and pedagogical implications http://respacoll.uzhnu.edu.ua/article/view/ 188462/187839 (accessed 12 January 2020), p. 286

${ }^{8}$ Fabian M. (2019). Interdisciplinary approach to cross-language and crosscultural communication studies. http://respacoll.uzhnu.edu.ua/article/view/ 187079/186480 (accessed 12 January 2020), p. 12. 
linguistic and professional competence - the teacher must carefully plan the work with the text, identify potentially problematic parts, prepare methods for processing their basic lexical and grammatical features, and come up with a set of relevant exercises. Traditionally, working with the text includes three stages, namely pre-textual, textual, and post-textual ${ }^{9}$ $[2 ; 4]$.

Let us consider the work with a thematic text by the example of $O n$ the Uses of Philosophy by Will Durant ${ }^{10}$ [7], intended for students of philosophy. There, the following stages can be identified:

\section{Working with active vocabulary included in the text}

Compiling a thematic dictionary to the text and working with this dictionary is one of the types of pre-text exercises that enable students to understand the main idea of the text and, subsequently, become the basis for understanding and acquiring new material. A thematic dictionary offers the lexical minimum, which makes it possible for students to speak on the given topic by providing the precise expression of thoughts and correct word usage. The lexical minimum can be used by students to read a thematic text with the accompanying task of studying the words and phrases on the given topic, finding in the text sentences with those words and phrases, and translating them, for example existence, meaningless, delight, incomparably, wistful, vacillation and futility, chaos, decipher, maelstrom, circumstance, inevitable, the creation of death.

In studying new words and phrases, it is necessary to follow a three-point plan: (a) finding out the meaning(s) of unfamiliar words and/or phrases, (b) writing them down and (c) learning the words and phrases by repetition. The first point (finding the meaning(s)) should not take up too much time if the following recommendations are applied: a word or phrase first has to be understood from its context, found in a bilingual dictionary or, should a student's vocabulary be sufficient, found in a monolingual dictionary. The general rule is to read the text carefully, clarifying the meaning(s) of each unfamiliar word or phrase.

Of particular interest at the pre-textual stage is the study of idiomatic expressions or phrasal verbs. In the first instance, it should be

${ }^{9}$ Kalinina L., Samoiliukevych I., Anderson K. (2001). Getting America-Wise through reading. Navchalnyi posibnyk $z$ anhliiskoi movy dlia studentiv vyshchhykh navchalnykh zakladiv. U 2-kh kn. Kyiv: Ped. dumka. Kn. 1, p. 4.

${ }^{10}$ The Story of Philosophy: navch. posibnyk z anhliyskoi movy (2017). Eds. S. O. Chernyshova, O. P. Tokmenko. Kyiv: VPTs "Kyivskyi universytet”, 142 p. 
explained to students that they are rarely to be used in formal writing and are more attributable to colloquial speech or belle-lettres. Since such expressions and phrases do not directly correspond with lexical units in students' native language, they deserve special attention and care. The teacher may need to use additional materials in order to help students use idiomatic expressions correctly in their speech.

It is therefore advisable that a separate set of exercises be prepared for learning idioms and phrasal verbs, such as inserting prepositions and/or adverbs; finding synonyms for highlighted parts of the text from among given idioms and/or phrasal verbs; filling in gaps with correct phrasal verbs; etc.

\section{Working with a thematic descriptive text}

After initial difficulties in comprehending the text have been dealt with, students move on to reading the given thematic text. Working with such texts pursues the aim of developing students' reading, pronunciation and translation skills. At this stage, students are asked to read and translate the text.

After reading the text, students do lexical exercises with a view to revising and checking their understanding of the text. Of particular importance are lexical exercises that contribute to developing the ability of determining the meaning of a given word or phrase in a particular context; determining the role of words in the lexical system of language; and analysing the meaning of a keyword (or keywords) in a particular context. The exercises recommended after reading the text should be designed in a way so that students will use the words and/or phrases selected at the previous stage for translating, retelling, and discussing the text, both orally and in writing. Such exercises often include the task of writing down keywords from the given text; answering questions based upon the text; or making up a plan of the text with the help of new vocabulary.

\section{Doing post-text exercises for revising the lexical minimum of the lesson, including translating English words and/or phrases into Ukrainian}

This stage helps students compare lexical units of different languages and ascertain their meaning. Such post-text exercises may include choosing a keyword or keywords from the given text and/or making up sentences with one and/or more keywords. 
To take an example, the following is an exercise that checks students' ability to make up correct sentences and use new vocabulary in correct contexts:

Make up sentences using the following words:

A pleasure, the Mirages, There, and, a lure, in, of, even, metaphysics, is, philosophy, in.

Another example illustrates how exercises can be used to both check students' comprehension of the given text and understanding of new vocabulary:

\section{Detect the right statement:} interpretation.

- Science is an analytical description; philosophy is emotional

- The scientist is as interested in the leg of a blessing as in the creative throes of a genius.

- Philosophy seems to stand still, perplexed; but only because she leaves no fruits of victory to her daughters the sciences.

- Philosophy accepts the hard and hazardous task of dealing with problems not yet open to the methods of science-problems like good and evil, beauty and ugliness, order and freedom, life and death.

Some exercises require selectively learning the given text's context. They include the fill-in-the-gaps type of exercises, such as the following one:

\section{Complete the following sentences:}

But the philosopher is not content to describe the fact; he wishes to 1) its relation to experience in general, and thus to get its meaning and worth; he combines things in 2) ; he tries to put it together better than before, that 3) which the inquisitive scientist has analytically taken apart.

It should be noted, however, that plainly taking parts of the given text for such exercises should be avoided. The teacher is to paraphrase parts of the text so that such exercises should be effective. In addition, if options are provided for each gap in such exercises and students are asked to choose the correct option, the teacher may ask them to explain why they have chosen this option over the others. Let us take the sentence from the above exercise to illustrate the point:

But the philosopher is not content to describe the fact; he wishes to 1) its relation to experience in general, and thus to get its meaning and worth...
A. purify
B. ascertain
C. locate
D. expand 
There, students must explain why option B is the only correct one, drawing upon the lexical and grammatical contexts of the sentence, i.e. option A ("purify") cannot be lexically used with "relation", etc.

Another effective type of exercises checking the understanding of the given text involves identifying redundant words, such as:

Read the text below and decide which lines of the text contain unnecessary words.

\begin{tabular}{|l|l|c|}
\hline$\#$ & \multicolumn{1}{|c|}{ Line } & Tick \\
\hline 1 & $\begin{array}{l}\text { In every field of activity there is a philosophy of it that } \\
\text { involves in }\end{array}$ & \\
\hline 2 & $\begin{array}{l}\text { questioning of its fundamental concepts, principles, } \\
\text { and methods. }\end{array}$ & \\
\hline 3 & $\begin{array}{l}\text { So, there is philosophy of science, philosophy of } \\
\text { religion, philosophy of }\end{array}$ & \\
\hline 4 & $\begin{array}{l}\text { art, and so on. Nearly always, some of the best } \\
\text { between practitioners in }\end{array}$ & \\
\hline 5 & each field are interested in its philosophy. & \\
\hline
\end{tabular}

The system of recommended exercises may also include those aimed at explaining the meaning of some phrases from the text, as is shown by the following example:

Define the meaning of the phrase:

"To be a philosopher," said Thoreau, "is not merely to have subtle thoughts, nor even to find a school, but to love wisdom as it is to live, according to its dictates, a life of simplicity, independence, magnanimity, and trust."

With this type of exercises, a post-text discussion can be organised, where students express their ideas as to certain parts of the given text.

The above types of exercises can be used to check students' work on the adequate understanding of new vocabulary and the text in question, and to contribute to the active acquisition of new lexical material. They can be done and, consequently, checked both orally and in writing, taking little to no time during the lesson, which allows the teacher to effectively use the lesson time devoted to working with the thematic text.

It should be noted that, at this stage of working with a thematic text, the student is able to come up with a cohesive statement based upon the material of the text. Exercises of this type may include answering questions not directly related to the given text but based upon it, with arguments provided in favour of the answer given. This is the 
communicational method of checking not only a deeper understanding of the text, but also the student's ability to formulate clear statements on a specific topic in a particular context. On a more general level, in answering a question, students learn to choose from the text relevant vocabulary and link it to the situation in which it can be used; transform the linguistic material being studied; and use lexical units in various forms. Asking students to provide argument in favour of their opinion helps engage them in speech-related activities at different levels of language competence. These are open-ended exercises, i.e. tasks that do not have one correct answer and allow students to deal with them whatever their language proficiency is. The type of exercises in question can be formulated as follows:

\section{text? \\ Skim the text quickly and write down what you can remember., etc. \\ Such exercises allow each student to give answers of the complexity and length that that they are able to. Even an unprepared student can express his or her own point of view by doing them. This incentivises each student to participate in classwork, and develops their overall language skills. At the last stage of working with text, the teacher may give students the task of finding additional information or discussing the ideas formulated in the text.}

Can you add some more of your own to the information of the

\section{Innovative technologies in teaching English}

The priority approach in contemporary pedagogies today is the learning-by-doing approach based on a student-centered model. This model involves active and engaged learners; independent, cooperative, collaborative, competitive learning (self, peer, groups), as well as studentled experiment and discovery. Innovative teaching technologies, active and interactive learning models are practice-oriented and require students' maximum activity and initiative, when they acquire knowledge on their own and the teacher only assists, directs and coordinates, i.e. the teacher becomes a professional facilitator who skillfully adjusts students' activity.

In our opinion, the most effective innovative learning technologies are the following forms and techniques:

- flipped classroom (the change in the way of presenting information; a flip between classwork and homework);

- double-flipped classroom (a role reversal between a student and a teacher); 
- gamification;

- project-based learning;

- case study;

- IT (digital / online / audio-visual resources);

- work in micro groups, teamwork that creates healthy competition, etc.

The increasing use of the practices of innovative technology in learning, teaching, research work and everyday life is crucial nowadays. The project-based learning (PBL) takes an important place among the innovative learning technologies. It is important, interesting and relevant for students because it demonstrates learning through practice, prepares future professionals to their professional activity and is the first attempt of professional self-realization.

We consider the "project" as a certain algorithm of actions, moderated by the teacher-facilitator and performed by students on their own, which is aimed at creating the final product. The results of the projects should be material, i.e. appropriately designed - video, PowerPoint presentation, poster as a consequence of practical research, development and design of the site, creation of digital stories, portfolios, photo collages, etc. It is designed to solve a problem, search for a common team solution and involves collaboration with peers. The purpose of the project is to create one's own product through cooperative activities.

While working on the project, students apply their knowledge and skills to solve realistic problems in the real world. Students acquire the experience of working in a team, negotiate, make common decisions and present the results of their activities together.

The project-based learning, as one of the innovative interactive learning technology, is gaining its popularity in the process of language (English) learning by the students of the National Aviation University (Kyiv, Ukraine). For instance, the third-year students majoring in "Journalism" ("Advertising and Public Relations") have created the project entitled "The Language of Newspapers" while studying "English for Specific Purposes", and the second-year students - the project entitled "The Language of Advertisement on the streets of Kyiv" during "English for Specific Purposes" course.

\section{Description of the projects \\ Project 1 \\ Project Title: "The Language of Newspapers"}


Type: practice-oriented linguistic project, aimed at developing students' language skills and skills necessary for future journalists.

Project participants: third-year-students majoring in "Journalism" (“Advertising and Public Relations") (24 students).

The final product of the project: The additional issue of "Aviator" newspaper (English version).

Topicality: A journalist has to develop the culture of speech and communication, as a literary language is the main tool of mass media. The ability to express the thoughts in writing, the ability to select the required information, and the development of skills to work in groups determine the relevance of this project. Working in a team with a set of responsibilities and tasks for each member encourages the student's autonomy and initiative. Students have to study the peculiarities of the journalistic style of English texts and compare them with Ukrainian ones, learn to write an article to a newspaper choosing the appropriate style, terminology, grammar forms and constructions

Purpose: to create a newspaper and develop the skills required for journalists in their future professional activity.

Tasks:

$\checkmark$ to analyze the writing style of American/British student newspapers;

$\checkmark \quad$ to define the journalism terms;

$\checkmark \quad$ to develop a set of skills necessary for future journalists: critical thinking and creativity (formulating ideas and solving problems), communication skills (writing and editing, making clear and well-written reports, explaining, articulating, presenting the material), organizational skills (setting and attaining goals, planning, meeting deadline); interpersonal skills (collaboration, working in a team to achieve a shared goal, assisting other team members), research skills (using various technological and information resources to collect information to create a new product);

$\checkmark$ to apply theoretical knowledge of language structure, spelling, punctuation, media techniques in practice while discussing and creating texts;

Duration: 3 months.

The plan of implementation:

$\checkmark$ preparation: students choose any British or American newspaper (e.g. Varsity (the newspaper of Cambridge University), The Harvard Crimson, etc) available online and make a thorough investigation into it for the content, style, terms, choice of grammar constructions and 
note their observations, present and discuss them in the classroom (webbased research, small groups discussions, class discussions);

$\checkmark$ students analyze the English version of 'Aviator' newspaper issued by the National Aviation University (Kyiv, Ukraine) both to detect any disadvantages in the content they would like to improve and identify any mistakes (e.g. inappropriate use of style, lexical and grammatical constructions);

$\checkmark$ setting the goal of creating the issue of 'Aviator' newspaper about the main events taking place at the National Aviation University, achievements and other topics of interest when students propose their ideas for content, pages, sections, columns, etc (brainstorming, class discussion);

$\checkmark$ students are divided into groups of five according to the newspaper section they have chosen, collect the material for this section, take interviews to prepare an article or articles for the newspaper (one page or section for each group);

$\checkmark$ each group of students proofreads the articles for errors and check the style, edits it for content and clarity, gives an attention-grabbing headline for the article, discusses the pictures or photos, etc;

$\checkmark$ students present the newspaper.

\section{Project 2}

Title: "The Language of Advertisement on the Streets of Kyiv"

Type (by method or type of activity dominating in the project): practice-oriented

Type (by content): linguistic, aimed at mastering the language material, developing certain language skills and skills of future copywriters, as well as studying linguistic features and linguistic realities.

Project participants: second-year-students majoring in "Journalism" ("Advertising and Public Relations") (26 students).

The final product of the project: PowerPoint presentation with the embedded video.

Topicality: the language of advertisement is an important tool for developing both the advertising industry and society as a whole, in which literacy is a factor in social success and one of the forces of professional growth. Nobody can be considered an educated person in the $21^{\text {st }}$ century without good communication skills (both oral and written, including correct speech). Therefore, a future copywriter has to develop the skill of critical attitude to advertising texts, revealing mistakes in them for creating their advertising texts in future professional activity. 
Purpose: to characterize and analyze the most frequent mistakes that occur in the advertisements on the streets of Kyiv, to develop recommendations for copywriters based on the analysis to enhance their culture of speech and avoid these mistakes in the future.

Tasks:

$\checkmark$ to identify the most common mistakes in the advertisements in Kyiv;

$\checkmark$ to organize the identified mistakes and classify them by presenting the results of the analysis in the form of diagrams;

$\checkmark$ to develop recommendations for enhancing the culture of speech for the authors of advertisements and to avoid similar linguistic mistakes in the future.

Duration: 2 months.

The plan of implementation: work;

- dividing students into micro groups, according to the type of

- collecting the material during the field research (mistakes in advertisements on the city streets);

- video recording to create a video clip;

- investigating the typology of mistakes and their systematization, in accordance with the violation of language standards;

- study of statistics (quantitative analysis of mistakes);

- creating a diagram based on the statistical analysis;

- creating the content of the text slides;

- video editing;

- creating a PowerPoint presentation.

\section{CONCLUSIONS}

The content derived from the given text and the system of relevant training exercises will form the basis for the development of competent dialogical and monological speech. Consequently, this leads to the next stage of working with the text, which involves processing information contained in the given text in order to formulate relevant, cohesive statements. The context of the text is used as the linguistic support for the development of students' linguistic skills as applicable in both oral and written speech. Formulating a statement based on the given text requires students to formulate the main idea of the text and select the relevant material from the text.

Therefore, lexical exercises formed on the basis of thematic texts are designed to develop students' lexical and linguistic competence. This 
allows students to correctly understand a foreign word; make conscious use of the structure of the meanings of foreign words; combine words and/or phrases in accordance with relevant lexical and grammatical rules; formulate and express an opinion in a foreign language in various form with thematic vocabulary; and finally, last but not least, understand thoughts expressed by other foreign-language speakers.

\section{SUMMARY}

In the paper, the author has provided guidelines on working with thematic texts with students of non-linguistic majors. It seeks to formulate effective and efficient methods of working with thematic texts, drawing upon the main types of working with texts in general. The article has made use of the method of analysing thematic texts and, therefore, argues that there are three basic steps in working with thematic texts, namely pretextual, textual, and post-textual. A set of exercises based on the book On the Uses of Philosophy by Will Durant has been used to illustrate the point. In the final analysis, the article argues that the methodology it sets out focuses on developing students' reading skills through helping them:

- correctly understand a foreign word;

- make conscious use of the structure of the meanings of foreign words;

- combine words and/or phrases in accordance with relevant lexical and grammatical rules;

- formulate and express an opinion in a foreign language in various form with thematic vocabulary;

- and understand thoughts expressed by other foreign-language speakers.

\section{REFERENCES}

1. Zahalnoieevropeiski rekomendatsii $\mathrm{z}$ movnoi osvity: vyvchennia, vykladannia, otsiniuvannia (2003). Nauk. red. ukrainskoho vydannia S. Yu. Nikolaieva. Kyiv: Lenvit, 2003, 273 p.

2. Kalinina L., Samoiliukevych I., Anderson K (2001). Getting America-Wise through reading. Navchalnyi posibnyk $z$ anhliiskoi movy dlia studentiv vyshchhykh navchalnykh zakladiv. U 2-kh kn. Kyiv: Ped. dumka. Kn. 1. 175 p.

3. Krat O. (2011). Komponenty systemy navchannia inozemnoi movy profesiynoho spriamuvannia cherez zmist profesiynoi diialnosti. Visnyk Dnipropetrovskoho universytetu imeni Alfreda Nobelia. № 2 (2). PP. 69-74. (Seriia "Pedahohika i psykholohiia"). 
4. Metodyka vykladannia inozemnykh mov $u$ serednikh navchalnykh zakladakh (2002). Pidruchnyk. Vyd. 2-e, vypr. i pererob; za red. S. Yu. Nikolaievoi. Kyiv: Lenvit. PP. 328-350.

5. Sekret I. V. (2010). Model formuvannia inshomovnoi profesiinoi kompetentnosti $\mathrm{v}$ umovakh dystanciynoi osvity. Visnyk LNU imeni Tarasa Shevchenka. № 17 (204). PP. 199-208.

6. Khrystova O. F. (2011). Vykorystannia fakhovykh tekstiv na zaniattiakh $\mathrm{z}$ angliyskoi movy za profesiynym spriamuvanniam / O. F. Khrystova // Naukovyi visnyk Melitopolskoho derzhavnoho pedahohichnoho universytetu imeni Bohdana Khmelnytskoho : zb. nauk. pr. № 6. PP. 220-225. (Seriia "Pedahohika").

7. The Story of Philosophy: navch. posibnyk z anhliyskoi movy (2017). Eds. S. O. Chernyshova, O. P. Tokmenko. Kyiv: VPTs "Kyivskyi universytet", $142 \mathrm{p}$.

\section{Information about the author: Svitlana Chernyshova,}

Ph.D., Assistant Professor of Institute of Philology, Taras Shevchenko National University of Kyiv 60, Volodymyrska str., Kyiv, 01033, Ukraine ORCID ID: orcid.org/0000-0003-0284-2001 
Publishing house "Liha-Pres"

9 Kastelivka str., Lviv, 79012, Ukraine

44 Lubicka str., Toruń, 87-100, Poland

Printed by the publishing house "Liha-Pres"

Passed for printing: February 7, 2020.

A run of 150 copies. 